\title{
Blood test ordering for unexplained complaints in general practice : the feasibility of a watchful waiting approach
}

Citation for published version (APA):

van Bokhoven, M. A. (2008). Blood test ordering for unexplained complaints in general practice : the feasibility of a watchful waiting approach. [Doctoral Thesis, Maastricht University]. Datawyse / Universitaire Pers Maastricht. https://doi.org/10.26481/dis.20080912mb

Document status and date:

Published: 01/01/2008

DOI:

10.26481/dis.20080912mb

Document Version:

Publisher's PDF, also known as Version of record

\section{Please check the document version of this publication:}

- A submitted manuscript is the version of the article upon submission and before peer-review. There can be important differences between the submitted version and the official published version of record.

People interested in the research are advised to contact the author for the final version of the publication, or visit the DOI to the publisher's website.

- The final author version and the galley proof are versions of the publication after peer review.

- The final published version features the final layout of the paper including the volume, issue and page numbers.

Link to publication

\footnotetext{
General rights rights.

- You may freely distribute the URL identifying the publication in the public portal. please follow below link for the End User Agreement:

www.umlib.nl/taverne-license

Take down policy

If you believe that this document breaches copyright please contact us at:

repository@maastrichtuniversity.nl

providing details and we will investigate your claim.
}

Copyright and moral rights for the publications made accessible in the public portal are retained by the authors and/or other copyright owners and it is a condition of accessing publications that users recognise and abide by the legal requirements associated with these

- Users may download and print one copy of any publication from the public portal for the purpose of private study or research.

- You may not further distribute the material or use it for any profit-making activity or commercial gain

If the publication is distributed under the terms of Article $25 \mathrm{fa}$ of the Dutch Copyright Act, indicated by the "Taverne" license above, 
Blood test ordering for unexplained complaints in general practice

The feasibility of a watchful waiting approach 
The studies presented in this dissertation were conducted under the auspices of the school for Public Health and Primary Care: CAPHRI at Maastricht University, The Netherlands. The school for Public Health and Primary Care: CAPHRI is part of the Netherlands School of Primary Care Research ( $\mathrm{CaRe}$ ), which has been acknowledged since 1995 by The Royal Netherlands Academy of Art en Sciences (KNAW).

Het drukken van dit proefschrift werd

financieel mede mogelijk gemaakt

door Medisch Coördinatie Centrum

Omnes

(c) M.A. van Bokhoven, Maastricht 2008

ISBN 978-90-5278-741-1

Layout: Tiny Wouters

Cover: $\quad$ Meteor Press b.v./Hoofdzaken; www.worldofexperience.com. Invulling: Hèlen Koch en Loes van Bokhoven

Production: Datawyse | Universitaire Pers Maastricht 


\title{
Blood test ordering for unexplained complaints in general practice
}

The feasibility of a watchful waiting approach

\author{
Proefschrift \\ ter verkrijging van de graad van doctor \\ aan de Universiteit Maastricht, \\ op gezag van de Rector Magnificus, Prof. mr. G.P.M.F. Mols, \\ volgens het besluit van het College van Decanen, \\ in het openbaar te verdedigen \\ op vrijdag 12 september 2008 om 14.00 uur
}

door

Marloes Amantia van Bokhoven

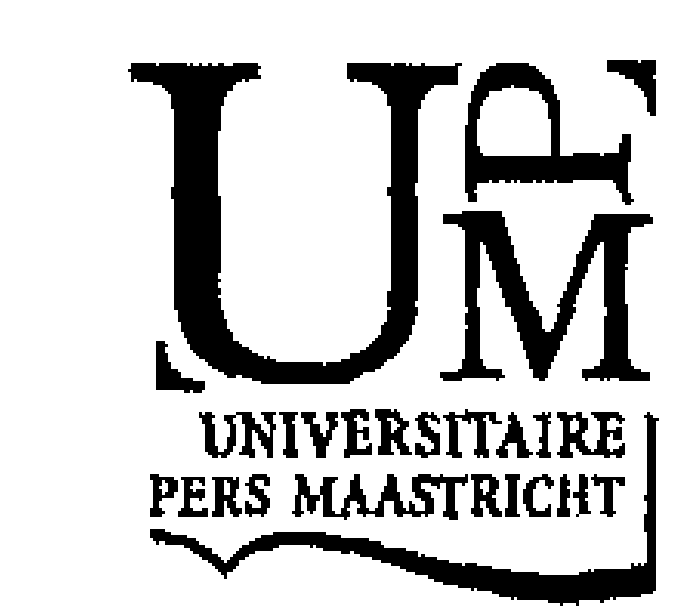




\section{Promotores}

Prof. dr. G.J. Dinant

Prof. mr. dr. R.P.T.M. Grol

Prof. dr. P.J.E. Bindels, AMC-UvA

\section{Copromotor}

Dr. T. van der Weijden

\section{Beoordelingscommissie}

Prof. dr. J.A. Knottnerus (voorzitter)

Prof. dr. J.M. Bensing, NIVEL

Prof. dr. P.A.M. van Royen, Universiteit van Antwerpen

Prof. dr. A.J.J.A. Scherpbier

Dr. J.A. Verbunt 
ALS VERANDEREN

NIET WIL

BEGINNEN WE

GEWOON OPNIEUW

Loesje

Aan mijn ouders 


\section{Contents}

$\begin{array}{ll}\text { Voorwoord } & 9\end{array}$

$\begin{array}{lll}\text { Chapter } 1 & \text { Introduction } & 17\end{array}$

Chapter 2 Understanding laboratory testing in diagnostic uncertainty: 31

a qualitative study in general practice

Br J Gen Pract 2002;52:974-980

Chapter 3 Why do patients want to have their blood tested?

A qualitative study of patient expectations

BMC Fam Pract 2006;7:75

Chapter 4 Designing a quality improvement intervention:

a systematic approach

Qual Saf Health Care 2003;12:215-220

Chapter 5 Blood test ordering for unexplained complaints in general practice, the VAMPIRE randomised clinical trial protocol BMC Fam Pract 2006;7:20

Chapter 6 Demographic characteristics and quality-of-life of patients with unexplained complaints: a descriptive study in general practice

Qual Life Res 2007;16:1483-1489

Chapter 7 The effect of watchful waiting instructions on GPs' blood test ordering behaviour for patients with unexplained complaints; a randomised clinical trial

Submitted

Chapter 8 The influence of a watchful waiting approach on satisfaction and anxiety among patients presenting with unexplained complaints in family practice

Submitted

Chapter 9 The costs of watchful waiting compared to immediate blood test ordering in patients with unexplained complaints in general practice, a randomised clinical trial Submitted 
Chapter 10 Exploring the black box of change in improving test ordering routines

Fam Pract 2008;25:139-145

Chapter 11 Challenges in the methodology of diagnostic research on 173 patients presenting with unexplained complaints in general practice $\mathrm{J}$ Clin Epidemiol 2008;61:318-322

Chapter 12 General discussion

Summary

Samenvatting

Publications

Curriculum vitae 


\section{Voorwoord}

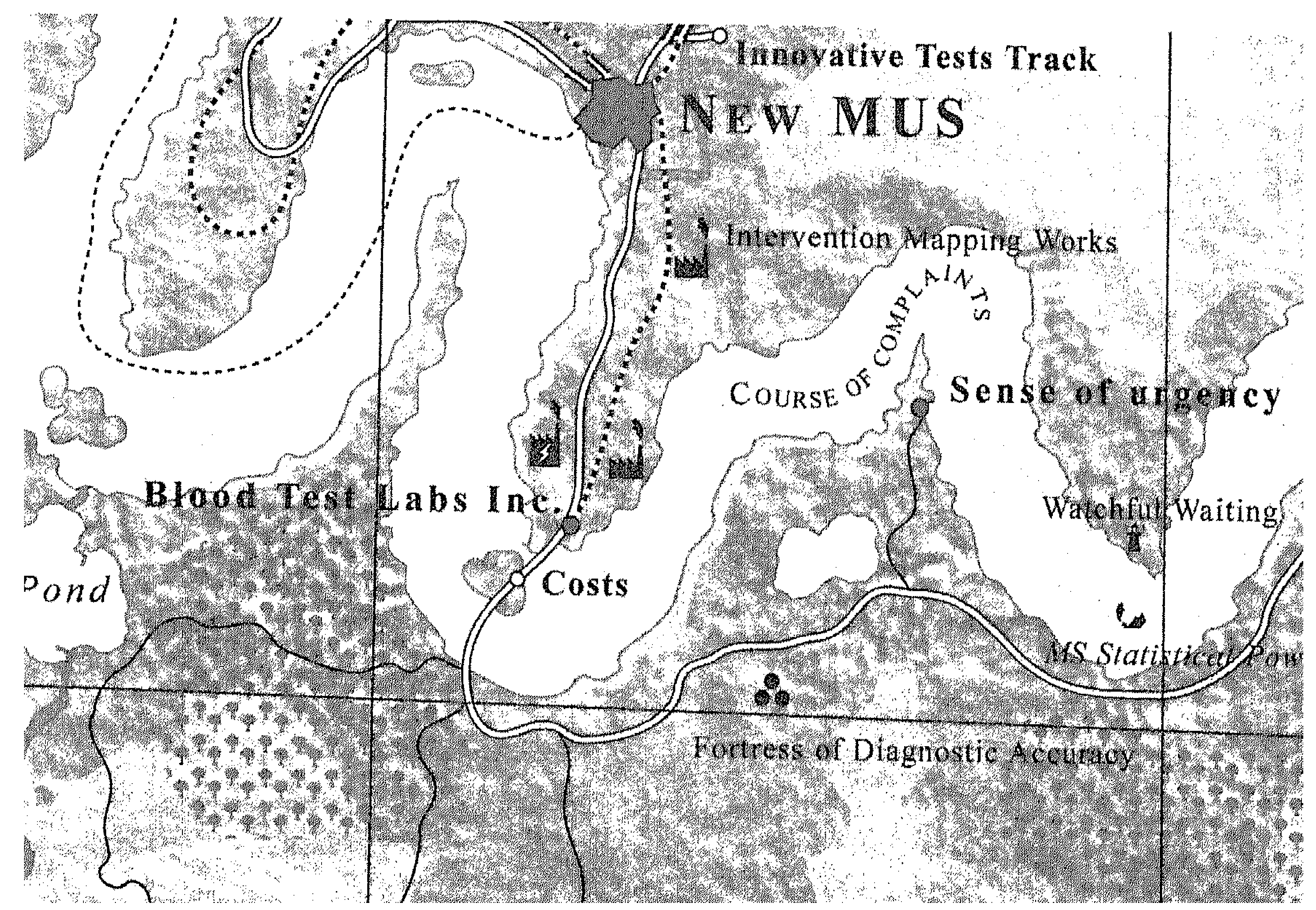




\section{Voorwoord}

Voor $u$ ligt mijn proefschrift. Hierin wordt een deel van het terrein van de onbegrepen klachten in kaart gebracht. Het proefschrift markeert niet alleen de afronding van het gepresenteerde onderzoek, maar ook het einde van mijn opleiding tot huisarts-onderzoeker. Mijn naam mocht op de kaft, maar aan de totstandkoming van dit boekje hebben veel mensen een bijdrage geleverd. Met het risico mensen te vergeten, doe ik toch een poging al deze mensen hier te noemen.

Allereerst mijn promotorenteam, maar liefst vier personen. Is dat vanwege de complexiteit van het onderzoek of van de te begeleiden onderzoeker? GeertJan Dinant, eerste promotor, bedankt voor je rol als coach. In het begin vooral het aanleren van onderzoeksvaardigheden, later liet je me, met je verhalen en adviezen, ook zien en ervaren wat er nog meer belangrijk is in onderzoeksland. Trudy van der Weijden, jij was altijd bereid om ook je bijdrage te leveren aan de minder 'scorende' klussen, zoals het coderen van interviews. Als één van de weinige moeders onder de onderzoekers vervul je ook een voorbeeldrol. Bovendien kon ik, vanaf een afstandje, zien hoe de ontwikkeling van een onderzoeker na de promotie verloopt. Richard, jouw begeleiding vond vooral op afstand plaats. Je vermogen om de kernboodschap in een dataset te zien en te verwoorden bewonder $\mathrm{ik}$ zeer. I $\mathrm{k}$ vind het dan ook een voorrecht dat je mijn artikelen van kritisch commentaar hebt willen voorzien. Patrick Bindels, jij moest aanhaken op een rijdende trein en het verbaasde me hoe snel je het overzicht had. Ik vond dat je erg goed was in het creëren van een werksfeer waarin we goed konden samenwerken. Dank ook voor de zorgvuldige manier waarop je iedere keer opnieuw naar de stukken keek. Pim Assendelft, jij stond aan het begin van dit project. Bedankt voor je enthousiaste inbreng in de opzetfase. Helaas lukte het je, door een aantal wisselingen van werkplek, niet om de begeleiding van het project voort te zetten.

En dan de onderzoeksassistenten. Door de jaren heen een hele club. Bedankt voor de goede sfeer en voor jullie flexibiliteit. Eerst Hilde Sielhorst, ervaren rot in het vak. Jij moet af en toe horendol zijn geworden van steeds weer nieuwe versies vragenlijsten. Jammer dat je koos voor een andere uitdaging en nog veel erger dat je, door omstandigheden, niet meer alles kan doen wat je zou willen. Daarna volgde Anuska Weekers. Anuska, jij hield in de inclusiefase de boel overzichtelijk, samen met Machteld IJff in Amsterdam. Onvermoeibaar was je in het reminden van de huisartsen. Machteld en Bert IJff, wat een enorme hoop uren hebben jullie gestoken in het logistiekprogramma! Maar het resultaat was er dan ook naar, het werkte geweldig. Paula Rinkens, jij zorgde voor de data-cleaning en een groot deel van de analyses. Ondanks de complexiteit van de dataset lukte het je om er een analyseerbaar geheel van te maken. Bij de 
laatste loodjes werd ik geholpen door Karin Aretz en Ger Driessen. Karin, in jou waardeer ik je duidelijkheid. Ger, het was heel bijzonder om te zien hoe handig jij bent met grote databases. Jammer dat jouw expertise voor onze vakgroep verloren gaat. Paddy Hinssen, Marie-louise Dumont en Karin Vaessen, jullie verzorgden verschillende secretariële taken en sprongen, vaak ad hoc, bij als er klussen waren, zonder daar ooit moeilijk over te doen.

Verschillende studenten sloten zich voor een periode aan bij het project en kregen een eigen vraagstelling om mee aan de slag te gaan. Het was iedere keer opnieuw weer leuk om te zien hoe iemand die kwam met het idee: onderzoek=statistiek=te moeilijk voor mij en saai, een met veel creativiteit uitgevoerd onderzoekje afrondde. Dorien, Marion, Jubi, Sandra, Jeroen, Yvonne, José, Agnes, Bess, Marjolein en Kirsten, bedankt voor jullie enthousiaste aanwezigheid.

Andere mensen brachten hun specifieke expertise in. Bij het maken van een wachtkamervideo: Wil Bleus en Robin Janssen van de AV-dienst uit het aZM, Michiel Jans als regisseur, Thijs Lenders en Jefte Lutgerink als acteurs. Echt een vak apart. Mooi om te mogen meekijken. Anneke de Jong, Henk Goettsch en Rutger Lulofs, als gedragswetenschappers begeleidden jullie het onderdeel arts-patiëntcommunicatie tijdens de nascholingsbijeenkomsten en slaagden erin de bijeenkomsten erg praktisch te houden. André Ament, als de economische analyses aan de orde waren, sprong jij bij met je bedachtzame commentaar. Gerben ter Riet, voor mij was je wat meer op afstand, maar vooral bij Amsterdamse analyses speelde jij een belangrijke, opbouwend kritische rol. Arnold Kester, statisticus, jij verstaat de kunst om in statistische lekentaal te overleggen over de beste benadering van de analyses.

De 63 huisartsen uit Noord-Brabant, Limburg, Flevoland en Noord-Holland die deelnamen en patiënten includeerden in het onderzoek, het was voor jullie niet gemakkelijk dit complexe project te integreren in jullie dagelijkse zorg. De 513 patiënten die trouw vragenlijsten invulden terwijl zij daar persoonlijk niets wijzer van werden: dank jullie allemaal voor alle inspanningen. De klinisch chemici en laboranten uit het Maasland Ziekenhuis in Sittard, het St. Jansgasthuis in Weert, het St. Anna Ziekenhuis in Geldrop, het Màxima Medisch Centrum in Veldhoven, het Diagnostisch Centrum Eindhoven, het Elkerliek Ziekenhuis in Helmond, de verschillende locaties van het Jeroen Bosch Ziekenhuis in 's Hertogenbosch, het Huisartsenlaboratorium in Haarlem en het Flevoziekenhuis in Almere. Het was een heel gepuzzel om de onderzoekslogistiek passend te maken voor de in ieder centrum gangbare procedures. Dank voor jullie geduld bij de verlenging van de inclusie en het wachten op de output.

Jan Klerkx, met veel gevoel voor het medische jargon sloeg je de spijker steeds op zijn kop als je suggesties deed om het engels van de teksten te verbeteren. 
Tiny Wouters, jij verdient een standbeeld voor je werk in de afrondingsfase van het proefschrift. Jouw ervaring gaat veel verder dan het lay-outen van het proefschrift, je bent tegelijk ook planner en zonodig mental coach.

Voor het onderdeel 'opleiding tot huisarts', stond een ander team voor me klaar. Yvonne van Leeuwen en Paul Ram, als opperhoofden van de huisartsopleiding hebben jullie enorm veel voor ons, Aiotho's gedaan. Vooral jullie aandacht voor ons persoonlijk welbevinden heb ik erg gewaardeerd. Henk Goettsch, als supervisor, verdient een eervolle vermelding. Jij liet zien dat de luxe van het hebben van keuze-mogelijkheden ook maakt dat je gedwongen bent keuzes te maken.

En dan de mensen bij wie ik, soms letterlijk, in de keuken mocht kijken. Fons van der Poel in Kerkrade. Je gooide me in het diepe en dat was even spartelen maar uiteindelijk erg goed. Het was een veelbewogen jaar waarin ik niet alleen veel medisch-inhoudelijke zaken heb geleerd, maar ook veel over samenwerking. Jouw wijnkelder is jaloersmakend. Van de tijd in de kliniek heb ik speciaal goede herinneringen aan Ad Kerremans in Helmond. Schoolvoorbeeld van een dokter die laat zien dat geneeskunde echt een academisch vak is. Bovendien een geweldige docent. De puntjes op de i werden gezet in Gezondheidscentrum Withuis in Venlo. Gijsbert de Koning, zelf vind je dat je expertise vooral op het medisch-technische vlak ligt, maar ik heb minstens evenveel geleerd van de manier waarop jij je gedachtengang tijdens het medisch proces en de alternatieven in beleidsmogelijkheden kon benoemen. Tonnie van Kessel, ik had het niet zo op aparte aandacht voor vrouwen in de geneeskunde, maar door jou ben ik me wel bewust geworden van de sexe-specifieke aspecten die in ons vak een rol spelen. Bovendien heb ik veel geleerd van de andere disciplines in huis. Wat een luxe, die korte lijnen!

Tot slot was er een grote afdeling 'Mentale Ondersteuning'. Zonder jullie had ik het niet gered en was het werken ook niet de moeite waard geweest.

In de eerste plaats mijn mede-Aiotho's van het eerste uur: Patrick, Katinka, Rogier, Marjolein, Niels, Roelf, Annemiek, Paul en Wemke. Het was een stevige ontgroening die we hebben gehad, maar hij heeft wel gewerkt: ondanks onze verschillen hebben we een stevige band. We zwerven langzamerhand uit, maar ik hoop op nog heel veel etentjes, feestjes en fanatieke discussies.

Mijn gang (inmiddels: aquarium) genoten. Ondanks veel wisselingen en parttime aanstellingen is er toch een vaste kern die altijd in is voor een inspirerende discussie en een geintje op zijn tijd. Een speciaal woord van dank voor Job, Ine, Ben en Marjan. Voor mij zijn jullie, ieder op jullie manier, een luisterend oor en klankbord.

Het team in de praktijk in Elsloo: Laury, Jos, Henk, Monique, Daniëlle, Chantal, Inge, Viënna, Myriam, Manon, Marloes en Lizette. Het is nog een beetje zoeken 
naar een nieuwe balans na alle veranderingen in de afgelopen periode, maar ik ben ervan overtuigd dat we die vinden, omdat de collegialiteit goed is. Dank jullie wel daarvoor.

Beste familie Koch, dit proefschrift is er grotendeels gekomen dankzij jullie dochter, zus, tante. Jammer dat Hans niet meer heeft kunnen zien wat een prachtige nieuwe auto zijn studerende dochter is geworden. Jullie hebben aardig wat voor de kiezen gehad de afgelopen jaren en ik bewonder jullie om jullie veerkracht en saamhorigheid.

Supervisiemaatjes, Ilse, Koen, Paul, Katinka, Marjolein, met Marie-José Metz aan het roer. Het is goed om te zien dat we in herkenbare en vaak vergelijkbare schuitjes ronddobberen. Jullie helpen me koers te houden en het bootje niet te zwaar te beladen.

Lieve vrienden. Met alle klussen voor het werk, schoot de tijd voor sociale contacten er weleens bij in. Gelukkig zitten jullie zelf ook allemaal niet stil. De momenten van contact zijn altijd weer warm en gezellig. Esther, we hadden al bijna samen een huis voordat we elkaar ooit hadden ontmoet. Ik ben erg blij met de vriendschap die daaruit is voortgekomen. Dank je wel dat je mijn paranimf wilt zijn. Marjolein, helaas ben je te ver weg om even over te komen, zelfs niet om paranimf te zijn, nu ik eindelijk het boekje af heb. Ik mis je als vriendin en collega, maar het is fijn om te zien dat je je plek gevonden hebt.

Lieve familie, Peter, Irene, Robert, Marieke, Erwin, Robert, Geb, Tineke, Pap en Mam. Het is vast niet altijd gemakkelijk geweest te snappen wat die (schoon)dochter / -zus nou aan het onderzoeken was, laat staan waarom dat zoveel tijd zou moeten kosten. Dank jullie wel dat jullie er waren en zijn, onze drukke agenda voor lief nemen en dat jullie bijsprongen op de momenten dat die agenda te weinig uren in een etmaal had. Lieve Pap en Mam, jullie weten inmiddels als geen ander wat een fout-negatieve uitslag betekent en dat heeft een flinke impact op jullie gehad. Maar nu is het feest en daar gaan we van genieten. Dank jullie wel dat jullie me altijd mijn 'eigen wijsje' hebben laten zingen.

Lieve Martijn, ik deel het standpunt uit de traumatologie dat een proefschrift een veel te omslachtige methode is om je levenspartner je genegenheid te tonen ${ }^{1,2}$. Dat doe ik dus op een andere manier en op een ander moment.

Lieve Jelle, in jouw doktersspel werkt lichamelijk onderzoek nog genezend en bij echte calamiteiten doet een kus nog wonderen. Lieve Elke, jij hebt nog niks met zorg of wetenschap, maar dat 'eigen wijsje' zit er bij jou al wel in. Jullie aanwezigheid is iedere dag weer een cadeautje.

Het laatste woord in dit voorwoord is voor Hèlen. Lieve Hèlen: onze boekjes zijn af! Bloed, zweet en tranen heeft het soms gekost, maar gelukkig wisselden we elkaar af in ups en downs. Dank voor je vriendschap en voor je geduld als ik weer eens met veel teveel dingen tegelijk bezig was en jij met je goede 
organisatie de prioriteiten in het oog moest houden. Weinig mensen zullen het voorrecht hebben van een paranimf die ook echt de verdediging zou kunnen overnemen. Dat is een geruststellend idee...(voor mij, wel te verstaan). Je ziet, dat dure EHBO-diploma van jou voorziet zelfs in dit soort acute opvang. Op naar de verdediging dus.

\section{Loes van Bokhoven}

\section{Reference}

1. Stapert J. Intramedullaire osteosynthese van het femur (stellingen). Maastricht: Maastricht University; 1983.

2. Verbruggen J. Reamed nailing of humeral fractures. Maastricht: Maastricht University; 2007. 


\title{
Chapter 1
}

\author{
Introduction
}

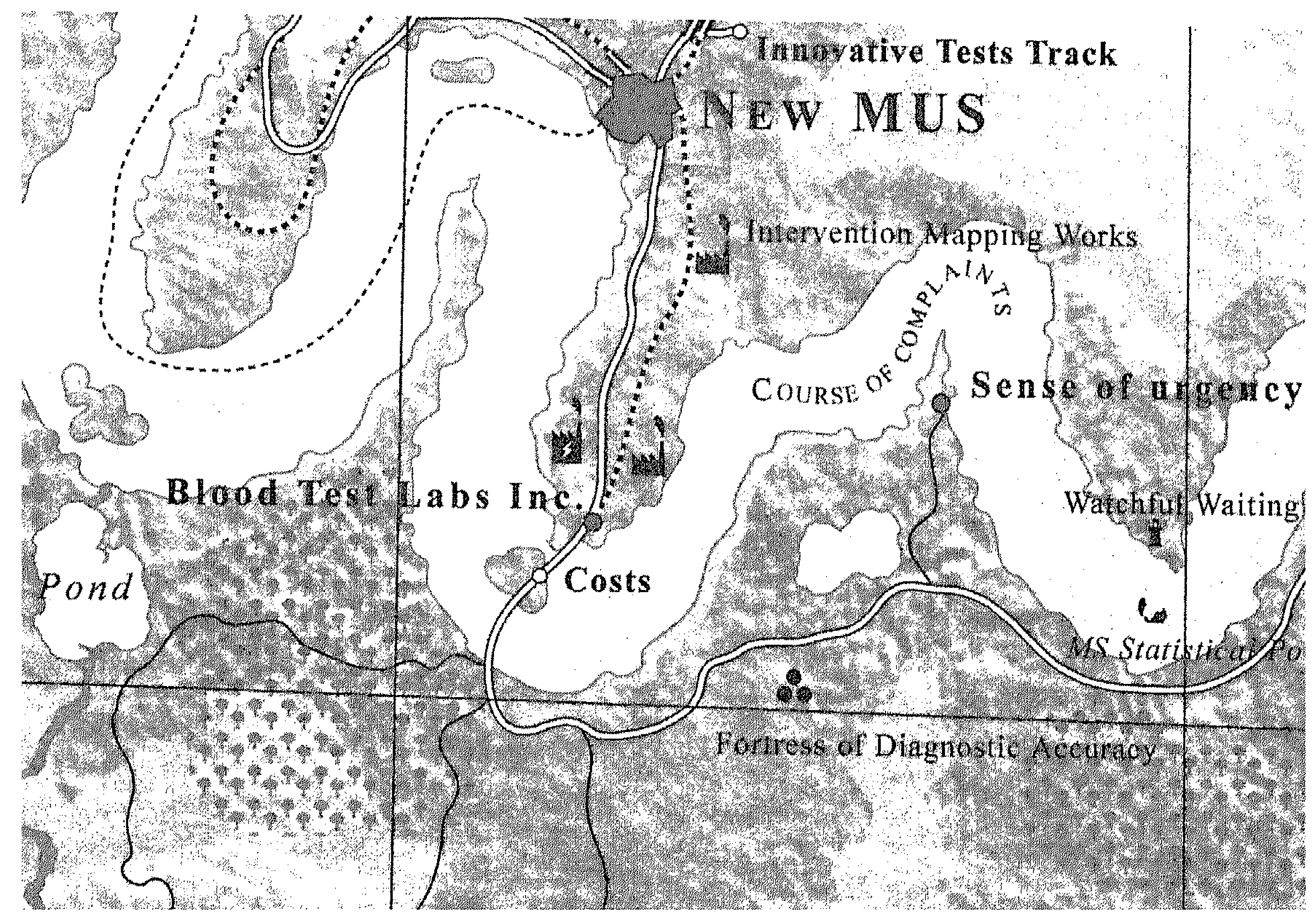




\section{Introduction}

This thesis discusses the systematic development and evaluation of a strategy to improve blood test ordering behaviour by applying a watchful waiting approach to patients who present to their general practitioner (GP) with unexplained complaints. This introductory chapter starts by presenting our definition of unexplained complaints and discussing their relevance in general practice. It then describes the expected pros and cons of two diagnostic blood test ordering approaches, namely immediate test ordering and watchful waiting. Subsequently, it discusses the problem of GPs' test ordering performance in current care and ways to improve their test ordering behaviour. The introduction ends with a summary of the research questions and an outline of the thesis.

\section{Unexplained complaints}

\section{Definition}

Unexplained complaints or medically unexplained (physical) symptoms are not unequivocally defined in the literature. The expressions are used for a wide range of clinical presentations, ranging from patients with diagnoses from the Diagnostic and Statistical Manual (DSM) IV in whom the physician is convinced that no somatic disease is present, such as somatisation, to patients presenting with new complaints that will most probably be self-limiting but may also be the first sign of serious disease ${ }^{1}$. In between these extremes there are various functional somatic syndromes, like fibromyalgia, irritable bowel syndrome and chronic fatigue syndrome.

Wessely et al. showed that each subspecialty seems to have its own 'syndrome', but that these should be seen as one, because symptoms, patient characteristics and response to treatment greatly overlap, in that e.g. patients with chronic fatigue syndrome, fibromyalgia, tension headache and other syndromes have several symptoms in common ${ }^{2}$. Burton found that symptoms of patients with unexplained complaints in general practice do not fully overlap with somatisation disorder or somatised mental distress ${ }^{3}$. Several authors suggest a different classification system for specialist care and general practice. An important difference with specialist care is that there is a broader spectrum of severity and duration of patients' unexplained complaints in general practice ${ }^{4}$. The classification in general practice should reflect this broad spectrum and include the dimensions of number and duration of symptoms, mood changes, patients' attributions and physiological processes, either within the DSM classification or in a classification of its own ${ }^{1,2,5,6}$. Although GPs tend to have experience with the entire spectrum of complaints presented by patients, their 
specific domain is patients presenting with complaints of recent origin, in view of their position as the point of entry to the health care system.

This thesis on patients with unexplained complaints uses the Dutch College of General Practitioners' (DCGP) definition of unexplained complaints: 'Complaints for which the GP, after clarifying the reason for encounter, history taking and physical examination, is not able to establish a diagnosis" ${ }^{7}$. This definition excludes diagnoses of chronic psychiatric clinical pictures like somatisation or hypochondria, which are sometimes referred to as 'unexplained' because patients present with somatic complaints, while no somatic explanation for the complaints can be found. However, the pattern of somatic symptoms does fit into a - psychiatric - diagnosis, and is therefore not unexplained according to the DCGP definition we decided to use.

The DCGP definition, however, does leave room for inter-doctor variance. Differences between GPs usually depend on whether they think it is necessary to find a pathophysiological or anatomical substrate before a complaint can be regarded as 'explained'. Since, for example, functional somatic syndromes have a recognisable pattern of symptoms, and several evidence-based therapeutic approaches are available, some GPs regard these complaints as 'explained'. For others, it remains questionable whether the complaints are symptomatic of an as yet unrecognised somatic or psychiatric diagnosis, and they do not have a treatment policy at hand. These GPs consider functional somatic syndromes to be unexplained. In the studies presented in this thesis we left the final decision to the GPs, in an attempt to reflect daily clinical practice as closely as possible.

\section{Epidemiology}

Patients with unexplained complaints are common in general practice; on average, $3-39 \%$ of contacts with patients involve complaints considered 'unexplained' by the $G P^{3,8,9}$. The complaints most frequently mentioned are fatigue, abdominal complaints, musculoskeletal complaints, headache and dizziness ${ }^{8,10}$

Although $90 \%$ of these complaints are found to be self-limiting within a month, there is a risk that complaints become chronic or represent the first sign of a serious disease ${ }^{11,12}$. It has been found that in $30 \%$ of patients presenting with fatigue, a diagnosis is eventually established. Of these diagnoses, half are somatic, one third are psychosocial and the remainder arise from a combination of the two ${ }^{13}$. The somatic diagnoses are mainly infectious diseases. Of patients with non-acute abdominal complaints, $86 \%$ had a non-organic diagnosis after a year. The other patients were given a variety of somatic diagnoses ${ }^{14}$. At present, the course of the remainder of unexplained complaints is not yet known. 
When these problems do become chronic, patients tend to make substantial use of medication and health care services. Most also suffer from psychological distress and decreased quality of life ${ }^{15-17}$.

\section{Blood-test ordering in patients with unexplained complaints}

\section{Immediate blood-test ordering}

When history taking and physical examination fail to yield a diagnosis, and complaints are thus unexplained, several authors suggest additional diagnostic testing ${ }^{13,18,19}$. Both laboratory tests and radiological tests have been recommended ${ }^{13,18,19}$. However, as the risk of serious disease in patients with unexplained complaints is low - less than $5 \%$ as a rough estimate - the risk of false-positive test results is relatively high ${ }^{20}$. This has to do not only with the imperfectness of tests and the methods used to take samples, but also with the fact that reference values have been determined on the basis of preset statistical margins of the general population. False-positive test results may lead to a cascade of superfluous further testing and treatments, unnecessary anxiety and even somatisation ${ }^{21,22}$. Harmful side effects of further testing and/or treatment may also occur. On the other hand, the predictive value of a negative test result is high when the risk of serious disease is low. Some physicians argue that they order tests to exclude diseases, in order to be able to reassure their patients. However, the pre-test probability of finding a negative result is already very high in patients presenting with unexplained complaints. Therefore, the additional value of testing to exclude disease is practically zero. Still, many GPs seem to perceive advantages of this approach, as they often order tests immediately.

To prevent superfluous additional test ordering for patients with unexplained complaints, clinical guidelines for test ordering have been developed ${ }^{7,23}$. The Dutch national guidelines for GPs on blood test ordering suggests ordering haemoglobin, erythrocyte sedimentation rate, thyroid stimulating hormone and glucose tests. The Dutch national problem-oriented laboratory test form has added creatinine and alanine amino transferase 'on indication' ${ }^{24}$. The available evidence on the diagnostic value of all proposed tests for patients presenting with unexplained complaints is limited, prevalence-driven and largely based on expert opinion and consensus ${ }^{25}$. 
$22 \mid$ Chapter 1

\section{Watchful waiting}

In order to overcome the high risk of false-positive test results in patients presenting with unexplained complaints due to the low prior probability of somatic pathology, the Dutch national guidelines for GPs recommend a 4-week watchful waiting approach. It is expected that most complaints will disappear within that period, reflecting their self-limiting nature ${ }^{12}$. Patients who still have complaints after four weeks might be at higher risk of serious disease. In addition, the clinical picture may develop into clearer symptoms and signs, facilitating a possible diagnosis or explanation for the complaints. Though this strategy has a good basis in Bayes' theorem, evidence about the effects of watchful waiting is limited. In terms of therapy, the approach has been used for the prescription of antibiotics in respiratory tract infections, where it may be cost-effective $^{26}$. The term watchful waiting has also been used in diagnostics, but with a different meaning than that used in this thesis. It is used to describe repeated monitoring by means of laboratory tests to determine when treatment is mandatory, e.g. monitoring prostate specific antigen levels in patients with prostate carcinoma to determine when a prostatectomy is needed ${ }^{27-29}$.

\section{Assessment of watchful waiting versus immediate test ordering}

From the perspective of diagnostic accuracy, watchful waiting appears to be superior to immediate test ordering. Watchful waiting is expected to reduce the number of patients who are tested, leading to cost reductions. Furthermore, it prevents the cascade of additional investigations and treatments, because of the smaller expected number of false-positive results, which also leads to lower costs. However, there may be other factors than considerations of diagnostic accuracy and efficiency that influence a GP's decision whether or not to order tests.

Firstly, it is not known whether GPs consider the watchful waiting approach feasible and acceptable in day-to-day practice. Many GPs seem to consider test ordering a more attractive approach than watchful waiting ${ }^{25,30-33}$. Little, however, is known about their reasons to order tests. The available evidence is predominantly opinion-based, although some determinants have been identified in earlier research ${ }^{32,34,35}$. One explanation may be the GP's personal characteristics, e.g. their experience as a physician, the school where they had their medical training, their involvement in guideline development and personality traits. It is known that these may influence test ordering behaviour ${ }^{32,35-41}$. Another explanation may be context-related factors, e.g. the type of practice and the amount of experience with a problem-oriented test ordering form ${ }^{35}$. A third explanation may be cultural factors. A GP's 'risk taking attitude' influences their behaviour, and as this varies between countries, it suggests cultural factors ${ }^{42-44}$. Furthermore, in some countries GPs run a serious 
risk of malpractice suits and therefore tend to practice defensive medicine and order many tests ${ }^{45-48}$. Watchful waiting may not be acceptable in such a situation.

A second factor that may influence a GP's test ordering decision is the acceptability to patients. The available evidence shows that many patients have high expectations of the diagnostic value of blood tests. They agree with the statement that it is better to test 1000 patients unnecessarily than to miss one disease in a patient ${ }^{49,50}$. Other studies have shown that patients become dissatisfied when they have to wait while they are suffering from complaints ${ }^{50-52}$, and some that patients' requests may influence a doctor's decision to order tests $^{8,53}$. It is not fully understood, however, why the patients' expectations are so high.

Thirdly, authors state that patients consider other aspects of care more important, such as being listened to and getting a clear explanation about the nature of their problem ${ }^{54,55}$. None of these studies, however, specifically looked at the attitude to watchful waiting in patients with unexplained complaints.

Patients may also become anxious as a result of a watchful waiting approach. A qualitative study showed that patients may be uncomfortable with clinical uncertainty, and that they expect to obtain definite information about their health from test results ${ }^{51}$. On the other hand, it is not clear whether normal test results reassure patients. A study among patients referred for echocardiography showed that most patients were not reassured by a normal result ${ }^{56}$. Another study found that explanations of the meaning of possible negative test results prior to the test could be reassuring ${ }^{57}$.

Although lower costs are expected from the watchful waiting approach, the opposite may also be true. Patients may feel worried when tests are not ordered immediately. As a result they may seek alternatives for test ordering, e.g. by purchasing over-the-counter medications. Costs of a watchful waiting approach in general practice have only been determined for antibiotics prescriptions and should also be studied with respect to tests for unexplained complaints ${ }^{26}$.

\section{Improving GPs' blood test ordering behaviour}

\section{The problem in current care}

The literature confirms that the unexplained character of complaints leads to many tests being ordered ${ }^{58}$. From a diagnostic point of view, there is thus room for improvement ${ }^{59,60}$. Inter-GP differences and sometimes even inter-regional differences may be considerable ${ }^{44}$. Verstappen et al. found an approximately three-fold difference between regions in the median numbers of laboratory tests ordered (468-1469), which could not be explained by case-mix factors ${ }^{35}$. As 
24 Chapter 1

explained above, there are several barriers that may limit implementation by GPs of a watchful waiting approach in day-to-day practice.

\section{Evidence-based development of a quality improvement strategy}

Changing GPs' behaviour requires a quality improvement strategy. However, two systematic reviews of the Cochrane Effective Practice and Organization of Care group (EPOC group) showed that the effectiveness of most strategies has been heterogeneous and limited ${ }^{61-63}$. Explanations for these disappointing results include the difficulty of changing existing practice, non-optimal choices of methods to change behaviour, and the use of inadequate methods to design and evaluate quality improvement strategies.

The use of rigorous research methods in quality improvement has now been generally accepted for the evaluation of quality improvement strategies and the implementation of evidence, and increasingly also for the problem analysis of the behaviour that is to be changed. The latter includes an analysis of the barriers to and facilitators of change ${ }^{64-66}$. However, a scientific approach should also be accepted for the process of designing a quality improvement strategy. Little is known, however, about the best approach. We opted for a planning method from the field of health education, known as Intervention Mapping, which uses the results of the problem analysis as a starting point. The development of the intervention then takes place in a theory-driven way. However, this approach was designed for patient education, and has not been applied to changing health care professionals' behaviour. It was therefore not known whether the Intervention Mapping methodology could be applied to this situation. Furthermore, the process of changing professionals' behaviour itself largely remains a black box, in spite of the systematic development of quality improvement strategies. It is therefore not known how these strategies influence the process of behaviour change. 


\section{Translation into research questions}

On the basis of the above considerations, we defined the following research questions for this $\mathrm{PhD}$ project:

1. What are the GP- and patient-related barriers and facilitators in the process of improving GPs' test ordering behaviour?

2. How can a quality improvement strategy to change GPs' test ordering behaviour for patients presenting with unexplained complaints be developed systematically?

3. What are the characteristics of patients presenting with unexplained complaints of recent origin in general practice?

4. What are the effects of a 4-week watchful waiting approach compared to immediate test ordering in patients presenting with unexplained complaints, in terms of feasibility, direct medical costs and patients' anxiety and satisfaction?

5. What is the effect of a systematically developed quality improvement strategy on the GPs' test ordering behaviour, compared with merely instructing GPs to postpone testing?

6. What happens to the barriers and facilitators perceived by GPs during the process of changing their blood test ordering behaviour?

We tried to answer question 1 by means of two qualitative studies. The barriers and facilitators perceived by GPs were examined by designing a qualitative study with semi-structured interviews based on surgery observations by one of the investigators. The barriers and facilitators perceived by patients were examined by means of semi-structured interviews with patients in the GPs' waiting room. To answer question 2, we studied the literature on methods of behaviour change. Questions 3 to 5 were addressed by designing the VAgue Medical Problems In REsearch (VAMPIRE) trial into blood test ordering for patients presenting with unexplained complaints in general practice. It was a cluster-randomised clinical trial, in which general practices were randomised over three groups. The GPs in group 1 were instructed to order blood tests immediately, those in group 2 to apply a watchful waiting approach and those in group 3 also to postpone test ordering, but supported by a systematically developed quality improvement strategy. The quality improvement strategy consisted of two small-group meetings and a practice outreach visit. Patient follow-up ended at 12 months after the initial consultation. The inclusion of patients into this study took place from February 2002 until December 2003. The GPs of group 3 also participated in a third qualitative interview study, to answer question 6 . They were interviewed during the practice outreach visit about the barriers and facilitators they had experienced during the change process. 
$26 \mid$ Chapter 1

This study was carried out in collaboration with researchers from the Academic Medical Center-University of Amsterdam, Division of Clinical Methods \& Public Health, Department of General Practice.

\section{Outline of the thesis}

After this general introduction, the barriers and facilitators regarding blood test ordering perceived by GPs are described in chapter 2, while the barriers and facilitators of patients are described in chapter 3 . Both were qualitative interview studies. Chapter 4 describes how we systematically designed a quality improvement strategy to improve diagnostic blood test ordering by GPs for patients presenting with unexplained complaints. The strategy was based on the results of chapters 2 and 3 .

The study protocol of the VAMPIRE randomised clinical trial is described in chapter 5 . In this trial, the generation of new diagnostic evidence ran parallel to the design and implementation of the quality improvement strategy. Chapter 6 describes the characteristics and quality of life of the participants of the VAMPIRE trial.

The results of the trial are discussed in the chapters 7,8 and 9 . In chapter 7 we discuss the feasibility of the watchful waiting approach for GPs who are merely instructed to apply it and for GPs who are exposed to a systematically developed quality improvement strategy. In addition to the GPs' test ordering behaviour, the chapter also evaluates intermediate outcome measures relating to the GPs' consultation skills. Chapter 8 describes the relation between the two diagnostic test ordering approaches and the satisfaction and anxiety among patients with unexplained complaints. Chapter 9 compares the costs of a watchful waiting approach with those of immediate test ordering.

For chapter 10 we interviewed the GPs who participated in the quality improvement strategy, to examine their barriers and facilitators during the process of behaviour change.

Designing the trial presented in this thesis was a challenging exercise, partly due to the nature of unexplained complaints. We had to seek methodological solutions for design problems that were not always straightforward. These challenges are discussed in chapter 11 .

Chapter 12 serves as a general discussion, which links the findings of the previous chapters, and which offers some implications for GP practice, for future quality improvement programmes and for further research. 


\section{References}

1. Fink $P$, Rosendal $M$, Olesen $F$. The classification of somatisation and functional somatic symptoms in primary care. Aust N Z J Psychiatry 2005;39:772-81.

2. Wessely $S$, Nimnuan $C$, Sharpe M. Functional somatic syndromes: one or many? Lancet 1999;354:936-9.

3. Burton $\mathrm{C}$. Beyond somatisation: a review of the understanding and treatment of medically unexplained physical symptoms (MUPS). Br J Gen Pract 2003;53:231-41.

4. Rosendal M, Fink $P$, Bro F, Olesen F. Somatization, heartsink patients, or functional somatic symptoms? Scandinavian Journal of Primary Health Care 2005;23:3-10.

5. Sykes R. Somatoform disorders in DSM-IV: Mental or physical disorders? J Psychosom Res 2006;60:341-4.

6. Mayou R, Kirmayer LJ, Simon G, Kroenke K, Sharpe M. Somatoform Disorders: Time for a New Approach in DSM-V. Am J Psychiatry 2005;162:847-55.

7. Dinant GJ, van Wijk MAM, Janssens HJEM, Somford RG, de Jager CJ, Beusmans GHMI, Dijkstra RH, Wiersma Tj. NHG-standaard bloedonderzoek. Algemene principes en uitvoering in eigen beheer. [Dutch College of General Practitioners guideline 'Blood testing. General principles and use by GP']. Huisarts Wet 1994;37:202-11.

8. van der Weijden $T$, van Velsen M, Dinant GJ, van Hasselt CM, Grol RPTM. Unexplained complaints in general practice. Prevalence, patients' expectations, and professionals' testordering behavior. Med Decis Making 2003;23:226-31.

9. Peveler R, Kilkenny L, Kinmonth A-L. Medically unexplained physical symptoms in primary care: A comparison of selfreport screening questionnaires and clinical opinion. J Psychosom Res 1997;42:245-52.

10. Sheehan JD. The management of medically unexplained symptoms. Semin Gastrointest Dis 1999;10:30-6.

11. Kroenke $\mathrm{K}$, Jackson $\mathrm{Jl}$. Outcome in general medical patients presenting with common symptoms: a prospective study with a 2-week and 3-month follow-up. Fam Pract 1998;15: 398-403.

12. Kenter $E$, Okkes I, Oskam S, Lamberts $\mathrm{H}$. Tiredness in Dutch family practice. Data on patients complaining of and/or diagnosed with 'tiredness'. Fam Pract 2003;20:434-40.

13. Valdini AF. Fatigue of unknown aetiology--a review. Fam Pract 1985;2:48-53.

14. Muris JWM, Starmans R, Fijten GH, Knottnerus JA. One-year prognosis of abdominal complaints in general practice: a prospective study of patients in whom no organic cause is found. Br J Gen Pract 1996;46:715-9.

15. Smith GR Jr, Monson RA, Ray DC. Patients with multiple unexplained symptoms. Their characteristics, functional health, and health care utilization. Arch Intern Med 1986;146:69-72.

16. Katon WJ, Walker EA. Medically unexplained symptoms in primary care. J Clin Psychiatry 1998;59:2015-21.

17. Feder A, Olfson M, Gameroff M, Fuentes M, Shea S, Lantigua RA, Weissman MM. Medically Unexplained Symptoms in an Urban General Medicine Practice. Psychosomatics 2001;42:261-8.

18. Penninckx HKM, Avonts $D$, Verhoelst F. Epidemiologische gegevens en filosofische overwegingen over de klacht moeheid. Bijblijven 7 Moeheid. Houten: Bohn Stafleu Van Loghum; 1991: 4-30.

19. Solberg LI. Lassitude. A primary care evaluation. JAMA 1984;251:3272-6.

20. de Vries H, Fechter MM, Koehoorn J, claessen FAP, de Haan M. Moeheid. Huisarts Wet 2002;45:27-31.

21. Vafiadis $P$. The dilemma of the unexpected result. Aust Fam Physician 1996;25:971-3.

22. Sherwood P, Lyburn I, Brown S, Ryder S. How are abnormal results for liver function tests dealt with in primary care? Audit of yield and impact. BMJ 2001;322:276-8.

23. Godwin M, Delva D, Miller K, Molson J, Hobbs N, MacDonald S, MacLeod C. Investigating fatigue of less than 6 months' duration. Guidelines for family physicians. Can Fam Physician 1999:45373-9. 
$28 \mid$ Chapter 1

24. van Balen JAM, van Suijlen J, Rutten WPF, Flikweert S, Guldemond Fl, Hens JJH, Koch $H$, Souverijn JHM, van der Laan JR, van Duijnhoven JLP, Walma EP. Landelijke Eerstelijns Samenwerkingsafspraak. Rationeel aanvragen van laboratoriumdiagnostiek. Actualisering van het landelijk model van het probleemgeoriënteerd aanvraagformulier. Utrecht: Nederlands Huisartsen Genootschap, Nederlandse Vereniging voor Klinische Chemie, Samenwerkende Artsenlaboratoria Nederland; 2006.

25. van Boven $\mathrm{C}$, Dijksterhuis $\mathrm{PH}$, Lamberts $\mathrm{H}$. Defensief handelen door huisartsen bij aanvullend onderzoek. Huisarts Wet 1994;37:473-7.

26. Coco AS. Cost-Effectiveness Analysis of Treatment Options for Acute Otitis Media. Ann Fam Med 2007:5:29-38.

27. Ross PL, Mahmud S, Stephenson AJ, Souhami L, Tanguay S, Aprikian AG. Variations in PSA doubling time in patients with prostate cancer on "watchful waiting": Value of short-term PSADT determinations. Urology 2004;64:323-8.

28. Jonler $M$, Wasson JH, Reda DJ, Bruskewitz RC. Analysis of watchful waiting studies. Prog Clin Biol Res 1994;386:291-302.

29. de Vries SH, Raaijmakers R, Kranse R, Blijenberg BG, Schroder FH. Prostate cancer characteristics and prostate specific antigen changes in screening detected patients initially treated with a watchful waiting policy. J Urol 2004;172:2193-6.

30. Kluijt I, Zaat JOM, van der Velden J, van Eijk JTM, Schellevis FG. Voor een prikje? Het gebruik van klinisch-chemische, hematologische en serologische bepalingen door de huisarts. Huisarts Wet 1991;34:67-71.

31. Hardison JE. Sounding boards. To be complete. N Engl J Med 1979;300:193-4.

32. Eisenberg $\mathrm{JM}$, Nicklin $\mathrm{D}$. Use of diagnostic services by physicians in community practice. Med Care 1981;19:297-309

33. Pop P, Beusmans GHMI. Laboratoriumonderzoek bij vage en algemene klachten. The Practitioner 1990(S19):75-81.

34. Connelly D, Steele B. Laboratory utilization. Problems and solutions. Arch Pathol Lab Med 1980;104:59-62.

35. Verstappen WH, ter Riet G, Dubois WI, Winkens R, Grol RP, van der Weijden T. Variation in test ordering behaviour of GPs: professional or context-related factors? Fam Pract 2004;21:387-95.

36. Ornstein SM, Markert GP, Johnson AH, Rust PF, Afrin LB. The effect of physician personality on laboratory test ordering for hypertensive patients. Med Care 1988;26:536-43.

37. Scholer SJ, Pituch K, Orr DP, Clark D, Dittus RS. Effect of health care system factors on test ordering. Arch Pediatr Adolesc Med 1996;150:1154-9.

38. Hindmarsh JT, Lyon AW. Strategies to promote rational clinical chemistry test utilization. Clin Biochem 1996;29:291-9.

39. Bugter-Maessen AM, Winkens RA, Grol RP, Knottnerus JA, Kester AD, Beusmans GH, Pop $P$. Factors predicting differences among general practitioners in test ordering behaviour and in the response to feedback on test requests. Fam Pract 1996;13:254-8.

40. Epstein AM, Begg CB, McNeil BJ. The effects of physicians' training and personality on test ordering for ambulatory patients. Am J Public Health 1984;74:1271-3.

41. Epstein AM, McNeil BJ. Variations in ambulatory test use: what do they mean? Med Clin North Am 1987;71:705-17.

42. Grol $R$, Whitfield $M$, de Maeseneer $J$, Mokkink $H$. Attitudes to risk taking in medical decision making among British, Dutch and Belgian general practitioners Br J Gen Pract 1990;40:134-6.

43. Nightingale SD. Risk preference and laboratory use. Med Decis Making 1987;7:168-72.

44. Zaat JO, van Eijk JT. General practitioners' uncertainty, risk preference, and use of laboratory tests. Med Care 1992;30:846-54.

45. DeKay ML., Asch DA. Is the defensive use of diagnostic tests good for patients, or bad? Med Dec Making 1998;18:19-28.

46. Owens DK. Defensive diagnostic testing- a case of stolen utility? Med Dec Making 1998;18:33-4. 
47. Birbeck GL, Gifford DR, Song J, Belin TR, Mittman BS, Vickrey BG. Do malpractice concerns, payment mechanisms, and attitudes influence test-ordering decisions? Neurology 2004;62:119-21.

48. Hartley RM, Epstein AM, Harris CM, McNeil BJ. Differences in ambulatory test ordering in England and America. Role of doctors' beliefs and attitudes. Am J Med 1987;82:513-7.

49. Stalenhoef JGA. Vragen over preventie in de NHG-enquêtes 1999. Huisarts Wet 2000;43: 196-7.

50. Stalenhoef JGA. Resultaten NIPO-enquête 2006: Wat vinden huisartsen en patiënten van elkaar? Huisarts Wet 2007;50:nhg 5.

51. Kravitz RL, Edward JC. Patients' perceptions of omitted examinations and tests. A qualitative analysis. J Gen Intern Med 2000;15:38-45.

52. Kravitz RL, Callahan EJ, Paterniti $D$, Antonius D, Dunham $M$, Lewis $C E$. Prevalence and Sources of Patients' Unmet Expectations for Care. Ann Intern Med 1996;125:730-7.

53. Cohen O, Kahan E, Zalewski S, Kitai E. Medical investigations requested by patients: how do primary care physicians react? Fam Med 1999;31:426-31.

54. Peck BM, Ubel PA, Roter DL, Goold SD, Asch DA, Jeffreys AS, Grambow SC, Tulsky JA. Do unmet expectations for specific tests, referrals, and new medications reduce patients' satisfaction? J Gen Intern Med 2004;19:1080-7.

55. Jung HP, Wensing $M$, Grol $R$. What makes a good general practitioner: do patients and doctors have different views? Br J Gen Pract 1997;47:805-9.

56. McDonald IG, Daly J, Jelinek VM, Panetta F, Gutman JM. Opening Pandora's box: the unpredictability of reassurance by a normal test result. BMJ 1996;313:329-32.

57. Petrie KJ, Muller JT, Schirmbeck F, Donkin L, Broadbent E, Ellis CJ, Gamble G, Rief W. Effect of providing information about normal test results on patients' reassurance: randomised controlled trial. BMJ 2007;334:52.

58. Campo JV, Jansen-McWilliams L, Comer DM, Kelleher KJ. Somatization in pediatric primary care: association with psychopathology, functional impairment, and use of services. $J$ Am Acad Child Adolesc Psychiatry 1999;38:1093-101.

59. Pineault $R$. The effect of medical training factors on physician utilization behavior, Med Care 1977; 15:51-67.

60. Miyakis S, Karamanof G, Liontos $M$, Mountokalakis TD. Factors contributing to inappropriate ordering of tests in an academic medical department and the effect of an educational feedback strategy. Postgrad Med J 2006;82:823-9.

61. Grimshaw J, Thomas RE, MacLennan G, Fraser C, Ramsay CR, Vale L, Whitty P, Eccles MP, Matowe L, Shirran L, Wensing M, Dijkstra R, Donaldson C. Effectiveness and efficiency of guideline dissemination and implementation strategies. Health Technol Assess 2004;8:1-72.

62. Grimshaw JM, Shirran L, Thomas R, Mowatt G, Fraser C, Bero L, Grilli R, Harvey E, Oxman A, O'Brien MA. Changing provider behaviour: an overview of systematic reviews of interventions. Med Care. 2001;39:112-45.

63. Bero LA, Grilli R, Grimshaw JM, Harvey E, Oxman AD, Thomson MA. Getting research findings into practice: Closing the gap between research and practice: an overview of systematic reviews of interventions to promote the implementation of research findings. BMJ 1998;317:465-8.

64. Wensing $M$, van der Weijden $T$, Grol R. Implementing guidelines and innovations in general practice: which interventions are effective? Br J Gen Pract 1998;48:991-7.

65. Davis DA, Thomson MA, Oxman $A D$, Haynes RB. Changing physician performance. $A$ systematic review of the effect of continuing medical education strategies. JAMA 1995;274: 700-5.

66. Campbell $M$, Fitzpatrick $R$, Haines $A$, Kinmonth $A L$, Sandercock $P$, Spiegelhalter $D$, Tyrer $P$. Framework for design and evaluation of complex interventions to improve health. BMJ Clinical research ed. 2000;321:694-6. 


\section{Chapter 2}

Understanding superfluous laboratory testing in diagnostic uncertainty

T van der Weijden, MA van Bokhoven, GJ Dinant, CM van Hasselt, RPTM Grol BrJ Gen Pract 2002;52:974-980

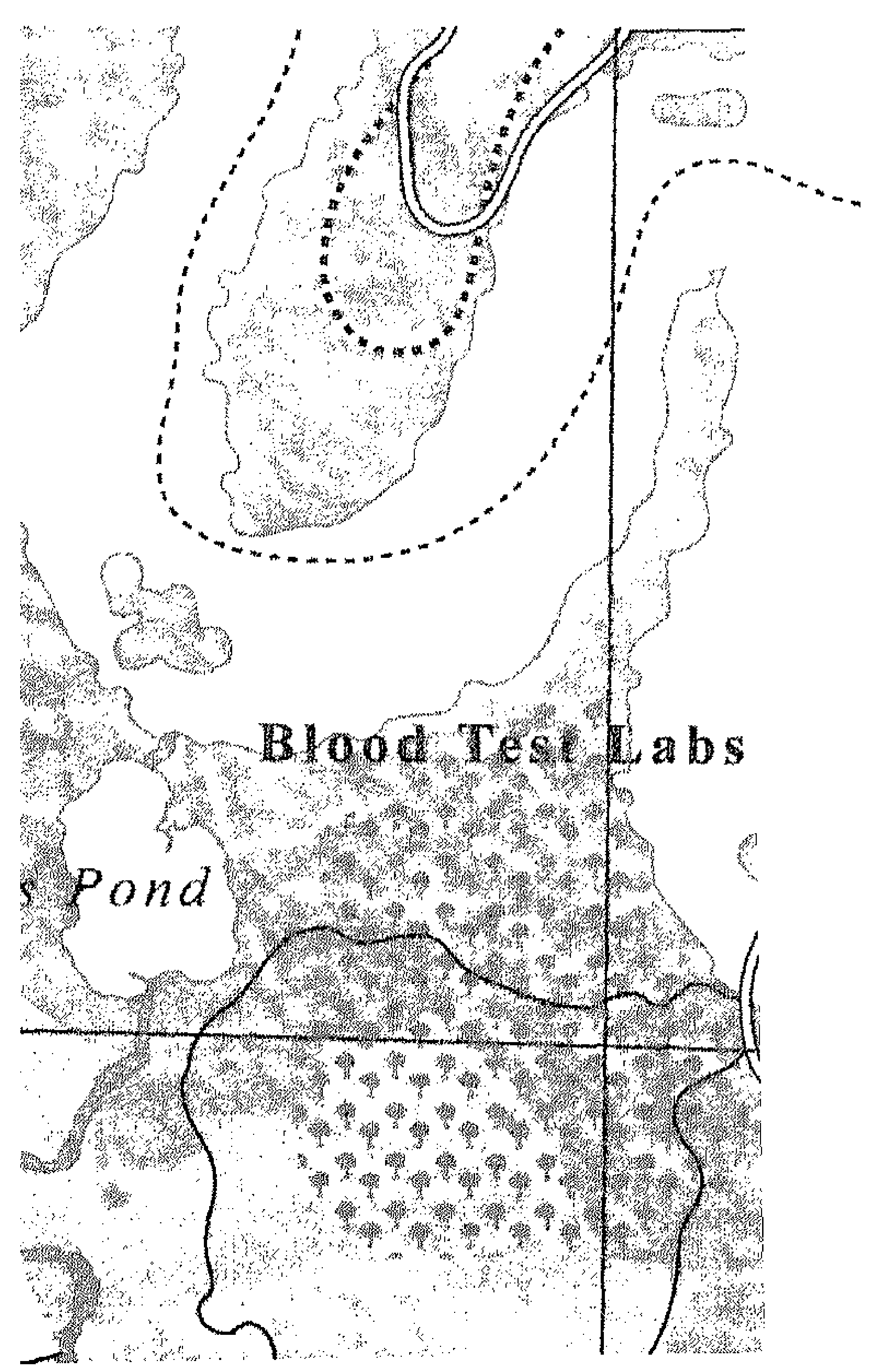




\begin{abstract}
Background

Better knowledge of the professional's motives for ordering laboratory tests in the case of diagnostic uncertainty may steer interventions directed at reducing unnecessary testing.

Aim

To gain insight into the general practitioner's motives for ordering laboratory tests for patients presenting with unexplained complaints.
\end{abstract}

Design of the study

Semi-structured interviews based on surgery-observations.

Setting

Twenty-one general practitioners (GPs) in rural and urban areas of the Netherlands.

\title{
Methods
}

Investigation of the GPs' perception of determinants of test-ordering behaviour in the situation of diagnostic uncertainty. The interviews were structured by evaluating the consultations and testordering performance of that day

Results

Dutch GPs vary considerably in their motives for test-ordering behaviour. Numerous motives emerged from the data. The main themes were: personal routines, tolerance of diagnostic uncertainty, pressure by the patient to perform laboratory testing (even if the patient does not explicitly ask for laboratory testing), time pressure, and tactical motives for test ordering. Complying with perceived needs of the patient for reassurance through testing is seen as an easy, cost- and
time-effective strategy.

\section{Conclusion}

The decision to request laboratory testing is the result of a complex interaction of often-conflicting considerations. Designers of interventions meant to improve test ordering should be aware of the numerous determinants. In order to reduce the amount of testing on non-medical grounds, GPs need to be trained in tolerating diagnostic uncertainty, and in negotiating about the limits of medicine with the patient. External, contextual variables should also be taken into account. 


\section{Introduction}

There has long been a discussion on the potential effects of 'superfluous' test ordering. Testing is called 'superfluous' if the test results do not influence the medical decision-making process (the general practitioner (GP) would have had the same management with or without the test result). Many authors contend that superfluous testing increases the risk of somatisation by labelling healthy persons as unhealthy or leads to an increase of false-positive outcomes, which in turn leads to a cascade of unnecessary interventions ${ }^{1-3}$. There is some controversy on the psychological effects of superfluous testing; testing, although it may be unnecessary from a medical point of view, is said to have positive effects on patients' mental well-being. Nevertheless, it raises the cost of health care and contradicts the rules of evidence-based medicine.

Particularly for patients presenting with unexplained complaints such as fatigue, dizziness and headache, many laboratory tests are requested ${ }^{4}$. As the incidence of serious disease is low in the general practice population, it is generally accepted that most of these tests are superfluous. In an attempt to stimulate rational use of testing in these situations, the Dutch College of General Practitioners (DCGP) developed a national guideline for laboratory testing for patients presenting with unexplained complaints ${ }^{5}$. In the DCGP guideline a deliberate delay of one month before ordering any laboratory tests is promoted. Despite the publication of this guideline advocating a watchful waiting attitude towards blood tests, the test-ordering behaviour in the Netherlands seems to be unchanged. Apparently, GPs have urgent motives not to adapt to the guideline. Insight into the motives underlying the test ordering behaviour is a prerequisite to generating ideas for interventions meant to improve test ordering.

The present study was carried out to investigate the GPs' perceptions of barriers to working according to this guideline. Which factors do GPs mention as influencing their decision to request laboratory testing when they are confronted with patients with unexplained complaints?

\section{Methods}

\section{Participating GPs}

Our goal was to elicit as many relevant factors influencing the test-ordering behaviour as possible. Therefore, in our sample of physicians, we aimed to vary the doctor-characteristics as much as possible. GPs were actively recruited, over the years 1998 and 1999, both in the north-west, urban part of the Netherlands, and in the southern, predominantly rural, part. GPs of different 
34 Chapter 2

ages, with varied work-experience, and of both sexes were recruited. GPs with special interest in complementary medicine, and with a divergent, nonrepresentative practice population (e.g. an Amsterdam practice with a multicultural patient population) were invited to participate. The GPs were informed that the purpose of the study was to gain insight into their decisionmaking process with regard to test-ordering, not to judge or criticise practice.

\section{Observations}

One of the authors $(\mathrm{CMvH})$ was present during consulting hours of the participating GPs. She was introduced to the patients as a researcher from Maastricht University. The purpose of her presence was explained, and a guarantee of anonymity was given. Detailed notes on a pre-structured form were taken of all consecutive patient contacts during the observed consultation hours. The notes concerned the reason for encounter, history taking and physical diagnostic examination, and the actual decisions about diagnostic management.

\section{Interviews}

The semi-structured interviews were conducted by one of the authors $(\mathrm{CMvH})$, in the surgery, immediately after the consulting hour. Each interview consisted of two parts. To begin with, all patients of the previous consulting hour were discussed as to the ability of the GP to give a specific diagnosis. All cases in which the doctor had been unable to give a specific diagnosis were discussed with the focus on the GP's motives for the decision to request laboratory tests. In the second part of the interview motives for test ordering were questioned more generally.

\section{Analyses}

The interviews were audio-taped and transcribed, and linked to the notes taken during the consulting hours. Interviews and notes were read and coded by two of the authors (CMvH and TvdW), independently of each other, according to the grounded theory on qualitative content analysis ${ }^{6}$. Differences in coding were solved through discussion. Rereading of the transcripts and ongoing discussion between the researchers led to a reduction of categories, major themes were retained and refined. The qualitative analyses were executed by using the software programme 'Nudist'. Saturation in the determinants was found after 12 to 14 interviews. Therefore, in the last set of interviews the dicussion was more focussed on the hierarchy in the test ordering determinants. The GPs were asked for their opinion on the existence of a hierarchy in the reported motives. 
After finishing the content analysis, the attitude-social influence-efficacy model was chosen to categorise the determinants of test-ordering behaviour ${ }^{7}$. The model, which is usually applied to describe determinants of patient behaviour, is an integration of social psychological models ${ }^{8-10}$. The assumption is that behavioural intention is determined by attitudes (cognitions and beliefs), perceived social influence, and self-efficacy expectations. These categories may all be modified by external variables, such as contextual or societal factors. The determinants are summarised in Table 2.1 and the meaning of the determinants are clarified by quotes in the text.

Table 2.1 Determinants of test ordering, factors that influence the GP in test ordering in patients presenting themselves with unexplained complaints.

$\begin{array}{ll} & \text { External variables } \\ \text { the practice organisation } & \text { societal perspective } \\ \text { - time pressure, lack of time } & \text {-low expenses, so why not? } \\ \text { - availability of technology } & \text { - societal tendency towards juridical claims } \\ & \text { - lower threshold for consulting a physician } \\ & \text { Internal variables }\end{array}$

category 1: attitudes general features of the GP (cognition and beliefs)

cognitions:

- higher pretest chance in older patient

- alarming somatic symptoms

- fear of medicalisation or insurance trouble

misconceptions:

- value of tests overestimated

- high belief in own experience uncertainty:

- dislike of risk taking

- small error tolerance

wish to comfort patients:

- "empty hands" feeling category 2: social influence the interaction between $\mathrm{GP}$ and others (social norms, pressure, support, modeling)

social influence from the patient:

- assertive patient

- prejudice on the patient's desire for reassurance

- worried patient, the patient needs to be reassured

- long-term relationship with patient

- realistic patient

- magic action, laboratory testing as a

ritual

social influence from the profession:

- influence of specialist

- insight in own test ordering behaviour category 3: self-efficacy GP's expectation regarding capability to perform the desired behaviour

perceived capability/skills:

- diagnostic capability

- ability in negotiating with the

patient

- fear for pitfall of somatising

patient

- ability to reassure oneself

- ability in history taking

other factors:

- routines, non-conscious skills

- condition GP; e.g. tiredness

- tactical motives for testing

\section{Results}

\section{Response of GPs and patients}

Twenty-one GPs were recruited. Only a very few patients did not give permission for observation during the consultation. The exact number was not registered, but it was less than $1 \%$ of the consultations. The total number of observed patient contacts was 567. A mean of 27 patient contacts (SD 15.6, 
$36 \mid$ Chapter 2

min. 7, max. 65) was observed per GP. On average, diagnostic uncertainty was, according to the GPs' opinion, the case in $13 \%$ of the consultations.

Factors that influence the decision to order tests for patients with unexplained complaints

In the model the external variables were subdivided by the micro (practice) and macro organisation (society) in which the health care is being delivered. The attitudes category consists of GP-related factors, the social influence category comprises factors related to the interaction between GP and patient or between GP and colleagues, and the self-efficacy category covers factors both related to the GP and to the context of the consultation.

A clear hierarchy in the determinants was not found. Perhaps, subject to many reservations, it can be stated that the following factors were given the highest ranking by the GPs: routines in diagnosis and screening, tolerance of diagnostic uncertainty, the patient's active request for laboratory testing, the GP's assumption that the patient needs reassurance by laboratory testing, time pressure, and tactical or strategic motives for test ordering.

External variables related to the context of the consultation or the societal setting

Time pressure, e.g. on the busy Monday mornings or Friday afternoons, or when the surgery is running late and (many) more patients are waiting. Requesting a laboratory test is a quick and efficient way to finish the consultation.

"Such a form is straightaway a non-verbal means of signalling the end of the consultation. You know what we'll do, we'll take some blood, and then come back. Next!" (GP 1)

"If I'm short of time, then I'm more readily inclined to take a laboratory form. Then I won't quickly have to do a very extensive dizziness examination. " (GP 10)

"If you had the time to do a thorough history-taking of all these people so that you could note it all down, so to speak. That is your basic complaint, these are roughly your life circumstances, and this is your work and family situation. Then I think that the result would be that people would say I think I've been well understood, listened to, and examined', and that there would be far fewer further investigations needed. But of course that is much too time-consuming." (GP 4)

Availability of technology, e.g. of desk-top test devices in the practice, makes it easy to perform testing. Travelling to the laboratory means a burden for the patient. Another trigger is the situation that the patient is already being sent for 
another test to the diagnostic centre, which creates a low threshold to do more testing.

"Now that we have a lung function machine here, of course we can then do more. If we have some small doubts about COPD, why not do more extensive diagnostics? Patients don't have to go to the hospital, it isn't a burden, nothing is injected." (GP 1)

Blood tests are, in general, not expensive. The costs are relatively low in this time of economic prosperity. So why not? The resources for comforting the patient are available.

"I do think that certainly some things are requested rather quickly. But then I think, goodness, someone takes his car to the garage twice a year for a service. What's really the problem if you don't feel too well to say, 'Doctor, can you just give me a check-up and do some blood tests?' And then, if I look around, ... in our society. Money's being spent in all directions, why can't l just once do something for someone to set his mind at rest. Even if this is not rational. Setting people's minds at rest is very important." (GP 2)

Defensive medicine due to the societal tendency towards juridical claims is another reason.

"People with claims, you refer them for further investigation because you feel that you have to cover yourself. That is certainly a tendency that you have to be somewhat aware of, that all kinds of legal complications can arise if diagnostic uncertainty persists for a long time." (GP 12)

There is a lower threshold for consulting a physician, or different pathology, than a generation ago.

"Yes, consumption has gone up considerably. Especially in the age group between 30 and 50. They come with many complaints, of a type that I think in the past was much less. Pelvic instability didn't exist. All the complaints of tiredness, that too I find increasing. I think I certainly request more than in the past, but whether that's because I'm afraid of missing things, or whether it's just the increase in presenting these vague complaints, I'm not quite sure." (GP 11)

Attitudes, general features of the GP

The pre-test probability of a test is higher in older patients, because they have higher risk of disease. The GPs mentioned 50 or 60 years of age as a turning point in their threshold for test ordering. Of course, for the same reasons as for the patient's age, the GP's threshold for test ordering also lowers in case 
alarming symptoms appear along with the unexplained symptoms, e.g. weight loss. A contrary determinant for test ordering is the fear for overtreatment, the fear of making healthy patients dependent on medicine. And the fear of insurance trouble for the patient if (minor) deviations in a test result, e.g. a X-ray of the spine, can be used against the patient by health insurers.

"I think that too many tests is not good. That it has a medicalisation effect, l'm well aware, and I take that into account. I find that many colleagues do treat the patients somewhat in this way though." (GP 4)

The diagnostic value of tests was often overestimated by the GPs. Some GPs showed a low level of epidemiological insight. These GPs did not realise that the diagnostic yield is most often nil. It may even lead to a wrong order in the decision-making process, e.g. first blood testing and later physical examination.

"Yes, and then I don't know in which direction I should think. I have to successively exclude certain things. Often I do blood tests first, and then a physical examination. Because I have so few leads, I get the blood tested first. The next time I examine the liver, look at the spleen and listen to the lungs." (GP 8)

The GP tends to base pre-test probability more on his or her own experience with individual patients than on clinical epidemiological data. There was a marked tendency to incorporate the 'once-in-a-lifetime' finding of an abnormal test result into one's own routine. For example, since an interviewee had found a hypercalcaemia in a patient with fatigue unaccompanied by other complaints or signs over 10 years ago, this GP always included this test in the lot, 'because you never know'.

"You occasionally see an iron overload. It also leads to vague complaints. So nowadays I always get a test for ferritine. I've recently had two which were above a thousand. Then you tell yourself that it's worth doing it straightaway." (GP 8)

"I always do sodium and potassium tests, because I once missed a case of Addison's, and liver and kidney functions." (GP 2)

The GPs seemed to differ quite a lot in their risk taking attitude. Some GPs found it difficult to handle insecurity, and in case they had decided for testing for their own comfort, to be selective in their test choice. It was felt that the amount of experience in working as a GP helps in handling security.

"I think we have the most difficult job. Let me give you an example. You're sitting there with someone who has a splitting headache, it had begun suddenly, but otherwise you see nothing alarming. Then you start weighing things up. Should you 
refer, or not refer? There's a family history of subarachnoidal bleeding. So I'm sweating there wondering whether to refer or not. So in the end / refer. Then the neurologist meets you with a laugh: 'It seems to me to be just hyperventilation'. I say, 'No, this isn't hyperventilation.' 'Yes, well, a CT scan has been planned anyway.' Now this man doesn't have to think about it anymore. A CT scan for an acute headache. $A$ specialist, he has this, that and the other, that's what we do in this complaint. Even if the pre-test chance is 0.01 . He does it anyhow. They have much more certainty than we do." (GP 6)

"I think in our work experience is much more important than only knowledge. Experience is crucially important. The fact that you have seen it once. Then you are so much more sure, you're much more comfortable if you've come across it or seen it once. It's different from how it's described in the books." (GP 7)

Some GPs experience small error tolerance because of (recent) medical blunder.

"If you're way off the mark... Then you really feel it in the pit of your stomach. Goodness, it did come out in the end. Naturally the patient then says, "'ve come here three times with this complaint and you always said that nothing was wrong.' Then I feel just so big (indicates preschooler height)." (GP 5)

"If you've ever experienced something like that, you can be sure that you'll send patients with vague complaints for further testing much faster. Absolutely. And then the lab coordinator might well write that the pre-test chance is only so great, but that's not how it works with us. Normally I sleep pretty well, but in such a case, then I sleep badly, or have a bad weekend. And if someone has cancer and it's definitive, then I have to tell the patient, but if he's already on his way home, then I forget it. But if your own policy comes up for discussion, then time ticks by." (GP 2)

Some GPs mentioned their frustration at not being able to offer the patient something useful. The feeling of empty hands, due to the lack of a diagnostic or therapeutic plan for patients presenting unspecific complaints. A test request symbolises a serious attempt to deal with the patient's complaint.

"I always find it difficult to get something across. Something that is difficult or not possible to treat. Because it is still a very frustrating complaint for the patients. So that's why you say, go along to the diagnostic centre. People must then feel that their complaint is being taken seriously." (GP 7)

\section{Social influence, the interaction between the GP and others}

The GP may experience pressure from the patient, who easily and actively asks for testing. Vice versa, if the patient spontaneously states "I think it is nothing 
serious", and does not ask for testing, the GP will more easily wait with test ordering.

"If he says this bothers me, and he comes back often enough, then he gets that blood test."

"What I request partly depends on age and on my feelings, however uneasy people feel, or on what they think about it themselves." (GP 3)

The GP assumes that the patient has a strong desire for reassurance by testing.

"Sometimes you can have wrong expectations yourself. Sometimes you think that this patient will definitely want an X-ray, and then, no. Sometimes it's happened to me that I think 'this patient will certainly want that'. And then I say something different, then I say that I haven't found anything, and they are then, to my surpirise, reassured. So you can surely make a mistake." (GP 4)

The worried patient needs to be reassured.

"This young woman of 21 years old. Her father had got severe rheumatism at a young age. Now she had problems with her feet and arms, morning stiffness, pain in the joints. But there was no redness, no swelling, wasn't warm, functioning was good. But she was still uneasy. I had to confirm this to her with a blood test, otherwise the discussion would go on and on. So I did a blood test straightaway. In her case she had been having relationship problems for a few months, which played a role. That did explain part of her uneasy feeling and what was the matter with her." (GP 7)

The GP is conscious of the enduring relation with the patient due to the continuity of care.

"The specialist can be very brusque, he can say, 'Yes, Miss, this is not for me, go back to your GP.' The specialist can botch it up, so that patient thinks 'He's kept me stringing along too long.' But the GP lives in the community, sees everybody, he has to continue caring for the patient. If you really mess things up, so that the patient switches to another doctor. That's what affects me." (GP 5)

The GP will more readily opt for test ordering when the patient is 'realistic', known to have a realistic view on complaints or a low medical consumption. Vice versa, with quickly worried frequent attenders, or somatising patients with high medical consumption, the GP will be more restrictive towards test ordering. 
Understanding superfluous testing $\mid$

"Yes, why this X-ray I wonder. Yes, I don't have a clear diagnostic plan. I don't expect any abnormality to show up on the hip X-ray. But nevertheless, she has that sort of serious complaints, and is realistic, I mean she doesn't come every week with complaints." (GP 10)

Laboratory testing is regarded as a trustworthy ritual by the patients, as a magic action. Many patients have a greater belief in technological medicine than in history taking and physical examination.

"Blood testing is naturally part and parcel of the treatment ritual, a somewhat magical treatment, which makes people willing to take the next step, willing to begin thinking about themselves. At first people are often not prepared, or not prepared for that. Trust in history taking and in physical examination is considerably less. So, you need another strong effect instead. Trust in technology is great. So, that is the scan or the blood test." (GP 11)

The GP may experience pressure from specialists, e.g. the already consulted specialist excludes disease but suggests focussing on other organ systems.

"Yes. If the neurologist had written, 'There's nothing the matter'. Then I would have said to the patient that you must accept it. But how must I say 'you have to accept it' if the neurologist says that perhaps the patient should be looked at by someone else." (GP 7)

The GP may, moreover, experience pressure from colleagues through insight into test-ordering behaviour. The GP, having a higher test-ordering rate than average, may be willing to change her or his test-ordering behaviour through modelling by feedback with comparison data from GP colleagues.

"If / get a letter from the diagnostic centre with the comment 'You request 10\% more than the average GP in Maastricht', then you get critical. You wonder if we should do nothing with this patient for the moment, just wait a bit longer." (GP 14)

Self-efficacy, the GP's expectation regarding capability to perform the desired behaviour

Some GPs feel insecure about their own diagnostic capability.

"I use the PSA test too, but that has to do with my insecurity. Because / don't rate my ability sufficiently good at present to correctly judge all prostates. I dare not go just on my rectal examination." (GP 1)

Some GPs find it difficult to negotiate with assertive patients. 
$42 \mid$ Chapter 2

"I don't know, it is one against the other. But / wouldn't know quite what arguments to use if he says, 'Doctor, can you give me a blood test?' Still, he who persists wins, he is always put in the right." (GP 1)

Some GPs are worrying about the pitfall of minimising risk of disease in phlegmatic patients, or in frequent attenders or somatising patients.

"With people who are a bit phlegmatic themselves, then you yourself also become somewhat phlegmatic. But here you have to be very careful. That you don't make a mistake. Like sending someone too late to the hospital because you go along with the behaviour of the person. You adapt your own self to the person who is sitting in front of you." (GP 8)

Sometimes the GP feels unable to reassure her or himself and to communicate this feeling. If an atmosphere of insecurity remains during the consultation, and the patient is sensitive to the GP's feeling of insecurity, he or she is not really reassured and will come back.

"Then you are somewhat uncertain. You reflect this uncertainty and then people come back with 'It isn't any better.' And then you are even more uncertain, and so you think, should I now order a blood test..." (GP 2)

A positive opinion towards the possibilities of history taking might help in postponing test ordering.

"With tiredness you come up against something of a psychological nature much more often than something somatic. I now ask questions quite differently. Since my training in ecological medicine, I ask much earlier and much more directly. Look, people come often with an outer story, but l ask more and more about the inner story, where is someone in their life, in which phase, what is someone occupied with?" (GP g)

Certain routines in diagnosis or screening play a role. Most interviewees had their own routines in test ordering. These routines were mostly a remnant of their medical education, sometimes modified by feedback given by the local laboratory and structured laboratory test-order form.

"Spinal cord patterns as I always call them. At a given moment you just got into the habit of a particular routine, and it is very difficult not to tick off certain boxes. I myself think that I ought to do so, but there I am with the patient and then I think: I'll let it be done just this time, next time not." (GP 10) 
The condition of the GP, e.g. tiredness after working a night shift, was mentioned by many GPs as being of influence of their test-ordering behaviour. If the GP is not fit, there is less enthusiasm for history taking and physical examination, or for informing or negotiating with the patient. Moreover, the feeling of insecurity is triggered more quickly if the GP feels tired.

"It varies a bit from day to day. If I've slept badly, if I've been on duty, then I find myself too a bit more uncertain. Then I feel more ready to get further tests done." (GP 8)

There are also tactical motives for testing; the test request is used as "change" in a refusal of a patient wish, or to create a somatic excuse, an organic substrate, for the complaint in order to assist the patient in accepting the complaint.

"He wanted a scan of his head and he wanted other tests too. Because / had refused him the scan, / let him have the other tests. But OK, that isn't as far-reaching, yeah, some blood tests. A scan means another place less at the neurologist's surgery." (GP 3)

"Yes, that's why l've done it. Simply because / think that now for once you can put a line under it, now for once you can clear it up. Or, just that it doesn't happen that you've been saying all the time 'it's nothing, there are no abnormalities on the X-ray', and then the orthopaedist takes a look and says, 'yes, it's logical, the vertebra is turned by about two degrees; or something like that. So the circle is round, so the story's fixed." (GP 14)

\section{Discussion}

The determinants of test-ordering behaviour in general practice are numerous and both medical and non-medical motives play their role. The decision to request laboratory tests in a situation in which the GP cannot formulate a clear diagnosis is the result of a complex interplay of often-conflicting considerations. Appropriateness of laboratory testing is not a purely medical issue. The study shows clearly that GPs use test ordering for many purposes in the consultation, and that the non-medical motives may be just as rational and legitimate in the overall context of a particular patient's care as the medical decision-making process. The context of the consultation and external factors such as the practice organisation or society contribute to the complexity. How all the investigated determinants interact probably remains an individual GP matter. But it also remains a matter of the uniqueness of each consultation with different factors being sometimes threshold-lowering, while other times 
$44 \mid$ Chapter 2

threshold-raising for the decision to order tests. Moreover, it is often difficult to know whether testing is required from a medical point of view, as this medical point of view itself seems to be dependent on attitudes of doctor and patient. The study did not reveal a definite, generalisable list of 'most important factors', or a generalisable hierarchy. Triangulation methods or quantitative validation of these findings might generate such insight.

The strength of this explorative study is that real practice was observed, and therefore actual considerations and decisions were critically examined in the interviews. This has two important advantages. To begin with, it is well known that actual patient-management in daily practice differs from indirect reports of the care given, e.g. by patient record audits, or verbal reports of standardised patients. Secondly, by looking at actual decisions that had been made, the unique character and context of each decision moment was recognised. A limitation is that only 21 GPs were interviewed and that: bias in the sample selection, despite our efforts, is not impossible. The fact that data saturation was found after 14 interviews is reassuring in this respect. Another limitation is the hypothesis generating, rather than hypothesis testing, character of this study. It is not the complete picture, because this study revealed perceived determinants only.

Non-medical determinants for test-ordering behaviour have already been sought in quantitative studies. It was for example found that GP characteristics such as age or working experience, number of working days per week, or type of reimbursement (fee for service) did have an influence on the amount of tests requested $d^{11-13}$. The patient's social class ${ }^{14}$ and insurance coverage type ${ }^{15}$ seem to influence test-ordering volume. Organisational factors such as the logistics and lay-out of the request form do have an influence ${ }^{4}$. However, both positive and negative relations with amount of test ordering were shown, and only a minority of the variation in laboratory utilisation was explained by the variables used in the analyses. This may reflect the complicated interplay of factors that determine test-ordering behaviour.

For the quality improvement interventions aimed at the professional it can be said that GPs need to have insight into their own (irrational) routines, and need to be trained in tolerating diagnostic uncertainty. GPs need more skills in negotiating with their patients about the limits of medicine, and in changing the patient's focus on health instead of disease. The GP should recognise the complaint, but at the same time help the patient to focus on healthy, positive findings. What is also important is the exploration of the need for reassurance behind the patient's wish for testing. Doctors must be able to identify the strategies whereby patients influence their clinical decisions and they must be able to respond to these strategies in ways that reflect patients' needs rather than their requests ${ }^{16}$. It might help if GPs could have a tool at their disposal to prevent the "empty hands" feeling in the situation where they want to delay test 
requests for a couple of weeks. Such a tool could be designed in various formats, e.g. in the format of patient education leaflets, decision aids for the patient, or a diary for the patient to register the course of the complaint, or a prescription for relaxation exercises.

This study revolves around the conflict between rationalising work (the application of guidelines) and patient-centred work (the practice of consultation). It is evident that this conflict cannot and should not be totally solved. The guidelines should not tie in the GP too firmly, GPs should remain to have the freedom, skills and abilities to tinker with them, to adjust them to the ongoing flow of contingencies that characterises medical work ${ }^{17}$. Designers of interventions meant to improve test ordering should be aware of the numerous determinants in the different categories. External, organisational variables should be taken into account. No single quality improvement intervention can tackle this complicated problem. But quality improvers should motivate their choice for an intervention tailored on the determinants that are most attractive and promising from a cost-effective point of view. 


\section{References}

1 DeKay ML, Asch DA. Is the defensive use of diagnostic tests good for patients, or bad? Med Dec Making 1998;18:19-28.

2 Owens DK Defensive diagnostic testing - a case of stolen utility? Med Dec Making 1998;18: 33-4.

3 Rovner DR. Laboratory testing may not glitter like gold. Med Dec Making 1998;18:32-33.

4 Zaat JOM, van Eijk JTM. General practitioner's uncertainty, risk preference, and use of laboratory tests. Med Care 1992;30:846-54.

5 Dinant GJ, van Wijk MAM, Janssens HJEM, Somford RG, de Jager CJ, Beusmans GHMI Dijkstra RH, Wiersma Tj. NHG-standaard bloedonderzoek. Algemene principes en uitvoering in eigen beheer. [Dutch College of General Practitioners guideline 'Blood testing. General principles and use by GP']. Huisarts Wet 1994;37:202-11.

6 Strauss A, Corbin J. Basics of qualitative research: grounded theory procedures and techniques. Newbury Park: Sage, 1990.

7 Kok GJ, de Vries $H_{1}$ Mudde AN, Strecher VJ. Planned health education and the role of selfefficacy: Dutch research. Health Educ Research 1991;6:231-8.

8 Fishbein $M$, Ajzen I. Belief, attitude, intention and behavior: an introduction to theory and research. Reading, MA, Addison-Wesley, 1975.

9 Bandura A. Social foundations of thought and action: a social cognitive theory. New York, Prentice-Hall, 1986.

10 Green LW, Kreuter MW. Health promotion planning; an educational and environmental approach. Palo Alto, Mayfield Publishing Company, 1991

11 Hartley RM, Charlton JR, Harris CM, Jarman B. Patterns of physicians' use of medical resources in ambulatory settings. Am J Publ Health 1987;77:565-7.

12 Kristiansen IS, Hjortdahl P. The general practitioner and laboratory utilisation: why does it vary? Fam Pract 1992;9:22-7.

13 Bugter-Maessen AMA, Winkens RAG, Grol RPTM, Knottnerus JA, Kester ADM, Beusmans GHMI, Pop P. Factors predicting differences among general practitioners in test ordering behaviour and in the response to feedback on test requests. Fam Prac 1996;13:254-8.

14 Hartley RM, Charlton JR, Harris CM, Jarman B. Influence of patient characteristics on test ordering in general practice. BMJ 1984;289:735-8.

15 van Merode GG, Stroink AE, Maarse JAM, Goldschmidt HMJ. Impact of insurance coverage type on laboratory test ordering behaviour of general practitioners. World Hospitals 2000;36: 7-11.

16 Salmon P. Patients who present physical symptoms in the absence of physical pathology: a challenge to existing models of doctor-patient interaction. Pat Educ Couns 2000;39:105-13.

17 Berg M. Problems and promises of the protocol. Soc Sci Med 1997;44:1081-8. 


\section{Chapter 3}

Why do patients want to have their blood tested?

A qualitative study of patient expectations in general practice

MA van Bokhoven, MCH Pleunis - van Empel, H Koch, RPTM Grol, GJ Dinant,

T van der Weijden

BMC Fam Pract. 2006;7:75

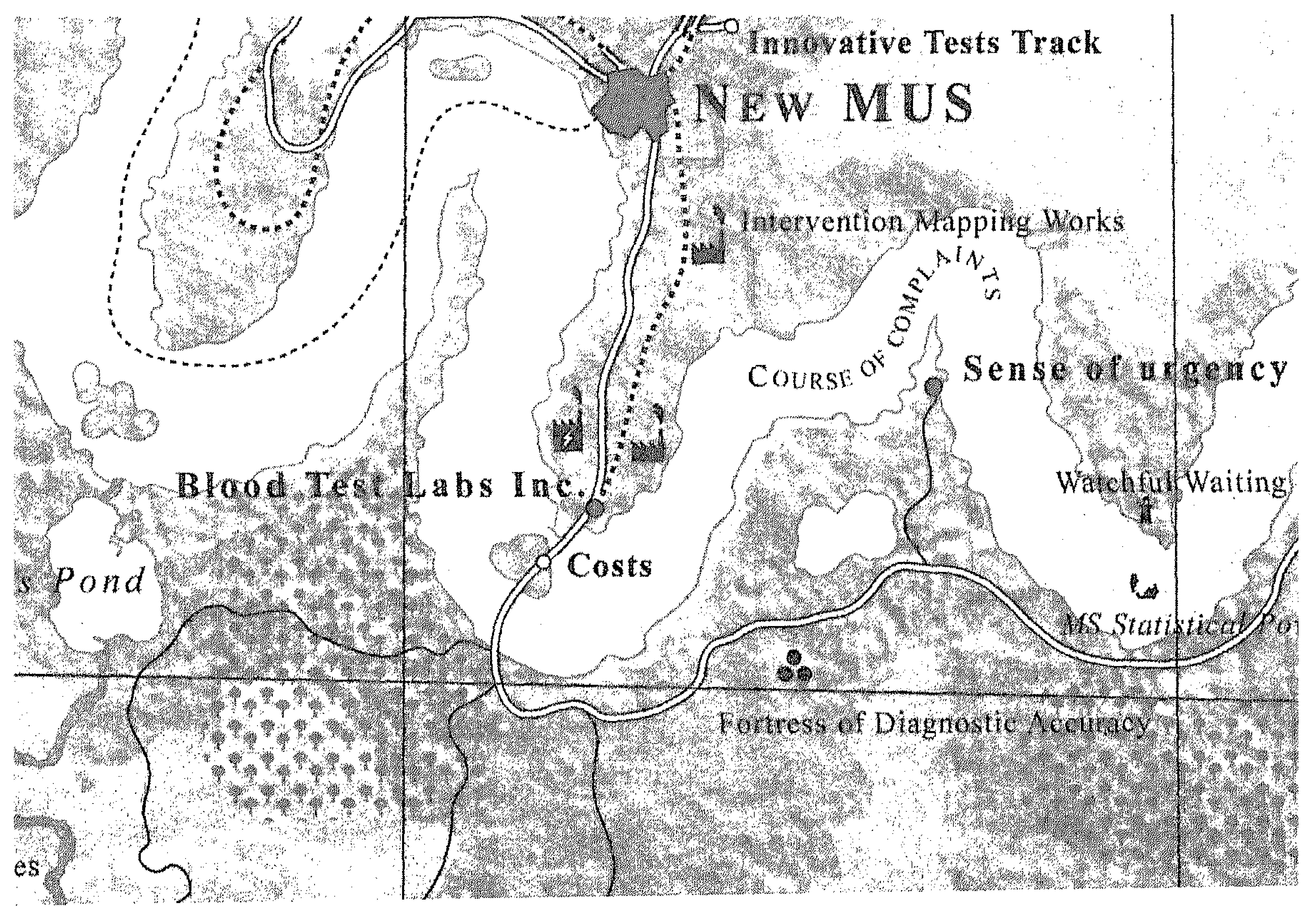


$48 \mid$ Chapter 3

\section{Abstract}

Introduction

General practitioners (GPs) often take their impression of patients' expectations into account in their decision to have blood tests done. It is commonly recommended to involve patients in decisionmaking during consultations. The study aimed to obtain detailed information on patients' expectations about blood tests.

\section{Methods}

Qualitative study among patients in waiting rooms of general practices. Each patient was presented with a short questionnaire about their preferences in terms of diagnostics. Patients who would like blood tests to be done were interviewed.

Results

Fifty-seven (26\%) of the 224 respondents wanted blood tests. Twenty-two were interviewed. Patients overestimated the qualities of blood tests. Favourable test results were regarded as proof of good health. Patients regarded blood tests as a useful instrument to screen for serious disorders, and were confirmed in this belief by people in their social environment and by the media. Many patients expected their GP to take an active test ordering approach, though some indicated that they might be convinced if their GP proposed a wait-and-see policy.

\section{Conclusions}

GPs' perceptions about patient expectations seem justified: patients appear to have high hopes for testing as a diagnostic tool. They expect diagnostic certainty without mistakes and a proof of good health. The question is whether it would be desirable to remove patients' misconceptions, allowing them to participate in policy decisions on the basis of sound information, or whether it would be better to leave the misconceptions uncontested, in order to retain the 'magic' of additional tests and reassure patients. We expect that clarifying the precise nature of patients' expectations by the GP may be helpful in creating a diagnostic strategy that satisfies both patients and GPs.

GPs will have to balance the benefits of reassuring their patients by means of blood tests which may be unnecessary against the benefits of avoiding unnecessary tests. Further research is needed into the effects of different types of patient information and the effects of testing on satisfaction and anxiety. 
Patients expectations 49

\section{Introduction}

Various studies have shown that general practitioners (GPS) regularly order blood tests without good medical arguments ${ }^{1,2}$. Unnecessary supplementary diagnostics have a number of disadvantages. In view of the relatively low apriori probability of serious disorders in the general practice setting, there is a rather high risk of false-positive test results, which could lead to unnecessary patient anxiety and superfluous further examinations ${ }^{3,4}$.

GPs often have non-medical reasons to order blood tests anyway, such as the desire to end the consultation or to reassure a patient, or the assumption that patients expect blood tests or see testing as an indicator of quality of care $e^{5-7}$. Although many GPs think that patients expect blood tests, this is not necessarily always true. Some patients mostly expect to be listened to and to get a clear explanation about the nature of their problem, rather than supplementary diagnostics, and patients' satisfaction does not appear to be related to being tested ${ }^{8-10}$. Many misunderstandings in the communication between GPs and patients arise from incorrect assumptions about the other's expectations ${ }^{11}$. Good communication requires that GPs are aware of patients' expectations ${ }^{12}$. There have been some quantitative studies into these expectations, which found percentages of patients desiring blood tests ranging from 14 to $22 \%{ }^{13-16}$. People tend to greatly appreciate blood tests. A 1995 survey showed that the majority of Dutch people think that an annual medical examination provides hard evidence of their health status, and that nearly all diseases can be cured, provided they are detected at an early stage. People rarely see the disadvantages of screening ${ }^{17}$. There thus appears to be a tension between the frequently limited diagnostic value of blood tests in general practice and the great appreciation for supplementary diagnostics among patients ${ }^{18}$. So far, however, no detailed information is available on patients' motives and their possible misconceptions especially as regards blood tests for diagnostic purposes, the impact of environmental factors on patients' expectations and the role of blood tests in the relation between patients and GPs. Such information would be valuable, as it might provide a basis for patient education. The purpose of the present study was a detailed assessment of patients' views on the value of blood testing when an actual desire for blood tests exists.

\section{Methods}

We conducted a qualitative study in three urban and two rural general practices in the southern part of the Netherlands ( $n=17 \mathrm{GPs}$ ), including the following types of practice: one single-doctor practice, three group practices with three to six GPs and one university-based group practice with four part time working 
GPs. The practices were recruited from a database of addresses of local general practices and the researchers' own network, the aim being to include as many different types of practices, and therefore different patients, as possible. Each practice was visited 1-3 times for a full working day by one of the authors (MP). In the waiting room, she invited patients who were at least 18 years old and able to speak Dutch to take part in the study.

Informed consent was obtained to collect the data. If patients refused to take part, only their sex and age category were recorded. All participating patients were presented with a short questionnaire, which asked for demographics and preferences regarding the use of diagnostics by the GP. The following phrases were used: 'Today you have an appointment with your GP. Would you like your GP not only to ask questions but also to do examinations? (yes; no; maybe; do not know). If yes or maybe, please answer question 6 ' and 'Which examinations would you like to be done? (physical examination (e.g. listening to heart or lungs, examination of your abdomen, blood pressure measurement); blood testing; urine testing; $x$-ray; scan; echo; otherwise, namely...; I do not know)'.

Patients who answered that they would like to have blood tests done were invited for a semi-structured interview. These interviews were, whenever possible, held before the consultations with the GPs, in order to minimise the influence of the GPs' actions on the patients' views. The interview systematically addressed the following subjects: complaints and ideas about the causes of these complaints, knowledge about and appreciation of blood tests, perceived influences from the patients' direct social environment, GPs and the media on the patients' desire to have blood tests done, reasons for the GP consultations, experiences with blood tests and patient anxiety. Questionnaires and interviews were anonymised to ensure patient privacy. The interviewer recorded the semi-structured interviews on tape and took notes on a structured form during the interview. The interviews were later typed out verbatim.

Two researchers (MB and MP) independently coded patients' answers in all interviews, using a cyclical approach, and then categorised the answers into a number of themes. Data saturation appeared to have been reached after about ten interviews, although the coding of one of the last interviews, with a patient who worked as a nurse, yielded a number of new themes. The codes and themes to be assigned were discussed by the coding researchers until consensus was achieved. Three researchers (MB, MP and TW) further discussed the themes, and categorised them into main topics, which emerged from the data. 


\section{Results}

\section{Population}

Three hundred and fourteen patients were invited to participate in the study, 224 of whom $(71 \%)$ filled in the questionnaire (Figure 3.1). Of the respondents, $57(26 \%)$ stated they would or might like to have blood tests done. Characteristics of the participants are summarised in Table 3.1. Twenty-eight of the respondents were interviewed, in most cases before the consultation with their GP. The other 29 were not interviewed, for a variety of reasons, mostly because there was not enough time or because several patients were eligible for an interview at the same time. A few patients refused to cooperate in the interview. In the end, 22 interviews were analysed, as six patients were found to have misinterpreted the questionnaire and turned out not to want blood tests at that very moment but at a not specified moment in the future. There were no differences in age or sex between these six patients and those who did want blood tests done.

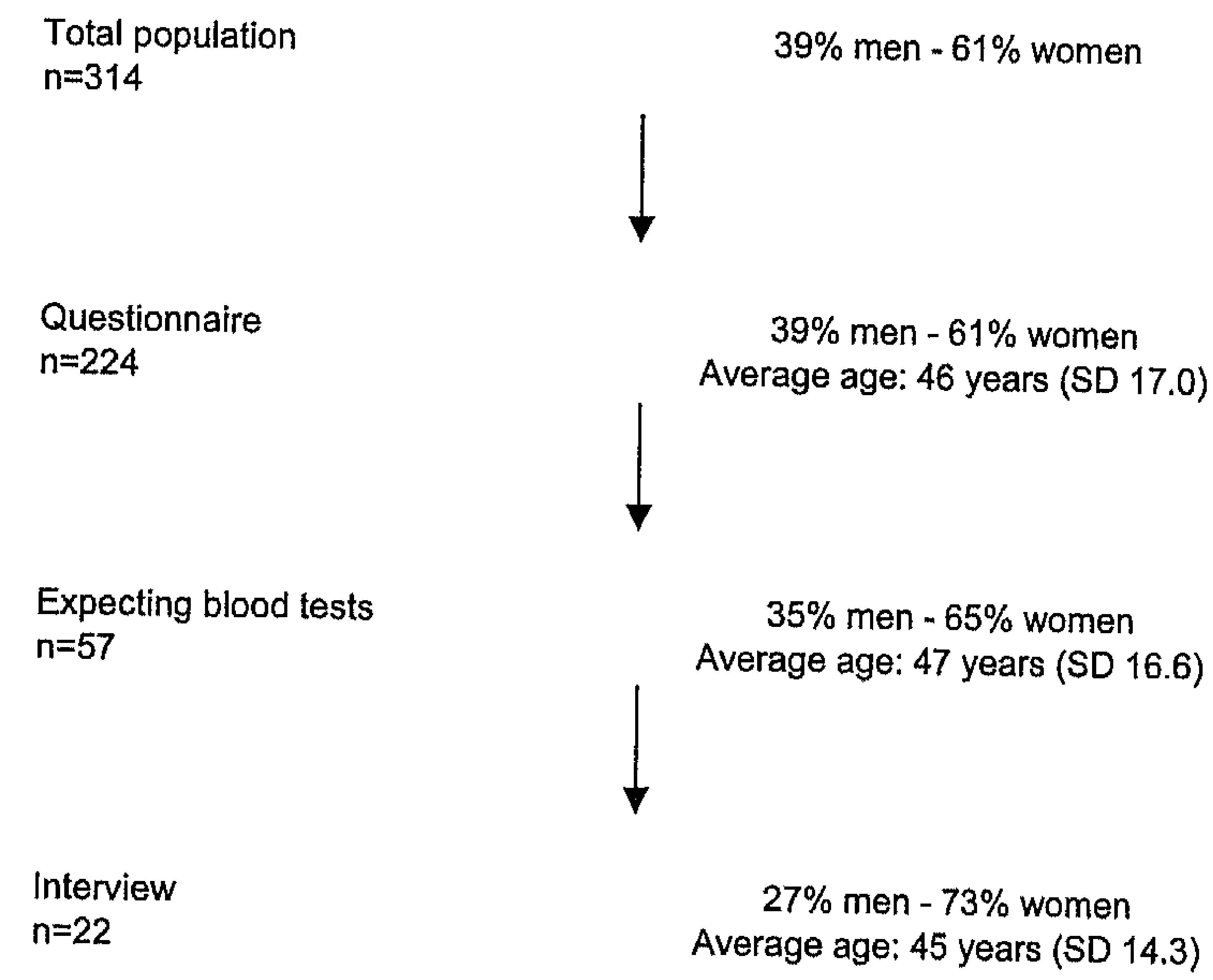

Figure 3.1 Flow diagram of patient inclusion. SD: standard deviation. 
Table 3.1 Demographic characteristics of participants.

\begin{tabular}{|c|c|c|c|c|}
\hline$n=224$ & \multicolumn{2}{|c|}{$\begin{array}{c}\text { No blood tests wanted } \\
n=167(74 \%)\end{array}$} & \multicolumn{2}{|c|}{$\begin{array}{c}\text { Blood tests wanted } \\
n=57(26 \%)\end{array}$} \\
\hline Age (mean (SD)) & \multicolumn{2}{|c|}{$45(16.8)$} & \multicolumn{2}{|c|}{$47(16.6)$} \\
\hline Sex & $n$ & $\%$ & $\mathrm{n}$ & $\%$ \\
\hline Male & 66 & 41 & 20 & 35 \\
\hline Female & 94 & 59 & 37 & 65 \\
\hline \multicolumn{5}{|l|}{ Country of birth } \\
\hline Netherlands & 139 & 86 & 46 & 81 \\
\hline Other western countries & 4 & 2 & 6 & 11 \\
\hline Other countries & 13 & 8 & 3 & 5 \\
\hline Unknown & 5 & 3 & 2 & 4 \\
\hline \multicolumn{5}{|l|}{ Highest level of education } \\
\hline Low & 27 & 17 & 7 & 12 \\
\hline Middle & 102 & 63 & 37 & 65 \\
\hline High & 31 & 19 & 12 & 21 \\
\hline Other/unknown & 1 & 1 & 1 & 2 \\
\hline \multicolumn{5}{|l|}{ Practice setting } \\
\hline Urban & 137 & 85 & 51 & 90 \\
\hline Rural & 24 & 15 & 6 & 11 \\
\hline
\end{tabular}

The patients who were interviewed gave different reasons for consulting their GP, ranging from cardiac complaints to psychological strain, or to be told test results. Four patients had complaints unrelated to their desire to have blood tests done (the latter being done by way of screening).

Most patients thought their complaints were caused by a somatic disorder. Three patients thought their complaints had psychological causes, but nevertheless wanted to have blood tests done to exclude somatic causes.

\section{Interviews}

Three main topics emerged from the data: motives from the patient to be tested, interpretation of results and alternatives to blood test ordering. The results are structured according to these three topics. The three main topics are presented in the headings and the themes within these topics are presented in italics in the text and summarised in Table 3.2. Some illustrative quotations are presented as well. 
Patients expectations $\mid 53$

Table 3.2 Summary of themes in relation to preference for blood tests.

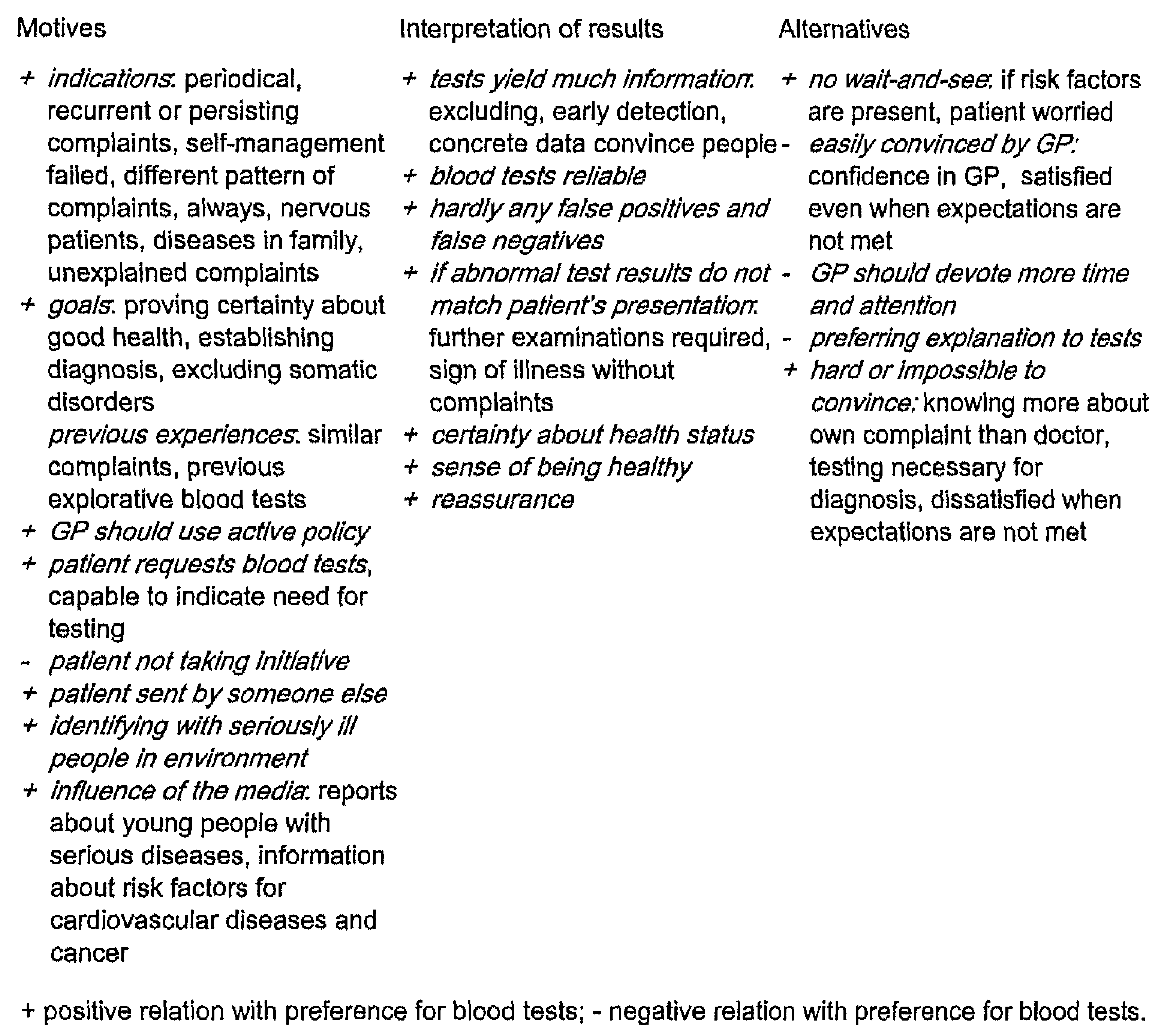

\section{Motives for wanting blood tests to be ordered}

The respondents mentioned several indications for having blood tests done. They considered it useful to have such tests done periodically, or for recurrent or persistent complaints, when self management failed.

(07103, woman, 19 years)

'Well, yes, in my case it is necessary [to test] because the complaints come back every summer, every spring. So most probably there is something more behind it.'

Another possibility was when the pattern of complaints differed from usual. Some said that tests should always be done if a patient has any complaints, and some felt that there is a greater need for blood tests if patients are nervous 
54 Chapter 3

or if there are diseases in the family. Many respondents thought that if a GP has no idea about the cause of a particular complaint and is therefore unable to establish a diagnosis (unexplained complaints), blood tests should be done to exclude certain disorders and to reassure the patient.

(18505, woman, 51 years)

'When you test] you can say concretely: "you do not suffer from that [disease]" and on balance that leads to lower costs for health care and it is a reassurance for the patient. Especially when patients think: "I have a certain disease" you can come up with concrete facts that the blood is all right so nothing is wrong.'

The goal of blood tests in their view was to ascertain a person is healthy, to establish the right diagnosis and to exclude somatic disorders, especially cancer and cardiovascular diseases, before discussing psychological causes.

(19003, woman, 21 years)

'I would like to have a test done for all diseases you can possibly get. So that at least you know that you're in good health, that you needn't worry. If your blood is OK, that means you're healthy.'

Respondents who had had blood tests done before were more likely to want new blood tests, should the same complaints return. If exploratory blood tests had been done before, they wanted renewed tests to monitor aspects like blood cholesterol.

(07103, woman, 19 years)

I had the same thing a couple of years ago ... they did blood tests then and found that the infection I had also affected the blood. I'm having the same complaints now, so / expect they'll do blood tests this time too.'

The respondents had little to say about their own contributions to the decision whether or not to order blood tests. Some respondents said that they would wait a while before consulting their GP, but would expect the doctor to take an active approach during the consultation. Respondents in this group often specifically asked for blood tests to be done, whereas there was also a group of respondents who would not take the initiative to tell their GP about their preference to have such tests done. One patient, a nurse, said she was capable 
of indicating the need of lab testing herself because of her professional knowledge.

(22405, woman, 44 years, a nurse)

No, because I am very convincing. I think that has to do with my background [as a nurse]. And when I think it is not necessary, I don't come. I hammered at it sometime. You visit once and once again and then you think: "this is not right" and then I think: "now I'm going to ask for what I want". And usually they do it then. And I have been correct several times.'

Many of the respondents had discussed their complaints beforehand with someone else, frequently their life partner. Some respondents had been sent to their GP by this other person, as he or she was worried about the complaint or thought they knew the cause. Other respondents had not been influenced by other people's opinions and came of their own accord.

(13103, woman, 36 years)

He [her husband, MB] thought I had had the complaints long enough and he said: "It has been long enough, go and visit the GP".'

Some respondents reported, often spontaneously, that they knew people who were seriously ill, and that this had induced them to consult their GP and ask for blood tests.

(06503, woman, 33 years)

'The main diseases among the people I know are definitely cancer and lung disorders. I also happen to have two acquaintances in their twenties who have breast cancer'.

The influence of the media was evident from the answers by respondents who said they had often read, or seen or heard programmes, about young people with serious diseases such as cancer. These sources also provided them with information about risk factors for cardiovascular diseases and cancer.

Interpretation of blood test results

The respondents thought that test results yield a great deal of information, and that they can be used to exclude most diseases or detect them at an early stage. The results were seen as convincing because they are tangible. In 
$56 \mid$ Chapter 3

addition, they supplement the GP's examinations, since a doctor cannot look inside a patient's body.

(08101, man, 61 years)

'The doctor and I are both just ordinary people, and the doctor can't look inside me to see what the matter with me is. That means that blood tests offer additional value in such a situation.'

The respondents thought that blood tests are reliable, and that errors are rare, since the tests are done by experts. The occasional incidents were thought to be caused by human errors or equipment errors.

(01401, woman, 41 years)

[on unexpected results:] 'I hope not, but it's possible. Anyone can make a mistake; people are not perfect. You can never exclude errors completely. There might be one in every so many thousands of tests, I guess?'

False positive and false negative results were considered rare or absent. Possible causes of unexpected results mentioned by the respondents were the use of medication, having a disease that was not reported beforehand, age, and being tired when blood samples are taken.

(13103, woman, 36 years)

'Yes, when external factors play a role. Like you took medication recently which you did not mention or when you suffer from a disease that you kept silent.'

In addition, false-negative results were thought to result from patients being in an early stage of a disease, in which it is not yet reflected in the blood composition. The respondents did not mention limitations of the tests themselves. Most respondents felt that if a test result is abnormal but the patient's presentation does not match this, further examinations are required to find the cause.

(03101, man, 65 years)

I think that I would go home to discuss and that I would request repeated test ordering some time.' 
Finally, they thought that people could be ill without having complaints. This was regarded as more likely than false-positive results.

The effects of blood tests were generally seen by the respondents as highly favourable. They felt that blood tests gave them certainty about their health status and gave them a sense of being healthy. They often presumed that the tests would show no abnormalities, and regarded normal test results as a guarantee of good health. Normal test results also reassured the patients.

(06303, man, 62 years)

I think that if you would blood tests once in a while, you would keep yourself informed about all sorts of things. Because you here such strange things.'

(02501, man, 60 years)

Interviewer: 'why would you like being tested?'

Patient: 'Because / do feel healthy now.'

Interviewer: 'What does blood test ordering have to do with that?'

Patient: 'Everything: how you're feeling, if you're feeling bad or well. In my case, this blood test ordering is usually all right for me.'

\section{Alternatives to blood test ordering}

A wait-and-see policy as an alternative to test ordering was often not favoured by the patients. They thought that doctors should not wait and see if patients are worried or if there are risk factors for pathology present, such as advanced age or long duration, or high intensity of the complaints.

(10501, woman, 38 years)

I work in health care myself, so I often have a pretty good idea ... And I know it's kind of a problem that goes with the profession, because you see so many diseases in your work. But at the same time I tend to think I have to get it out of my head, and I can only do that by doing something about it. And I want to be able to exclude certain things. I feel like I know my own body and it's giving me a signal that something is wrong.'

When discussing the possibility of alternatives to test ordering, one group of respondents said they would be easily convinced if the doctor thought blood testing was not indicated. People in this group had great confidence in their GP and were later satisfied with the policy adopted by the doctor. 
58 Chapter 3

(15302, woman)

'Sure she can convince me that [a wait-and-see policy] is best. I would not be disappointed in the doctor if she told me that'.

Some thought it more important that their GP devoted enough time and attention to them and explained things, rather than order blood tests.

(06503, woman, 19 years)

"I only expect the doctor to devote enough attention to his patients. Perhaps he should take a bit more time for each patient, as it were, rather than just telling you when you visit him: "Take this or that and come see me again if it doesn't clear up within two weeks". Sometimes the whole consultation lasts only five minutes, which I think is not good.'

The other group said that they would not be easily convinced, or not at all, and thought they knew more about their complaint than their GP. These patients thought that a doctor cannot establish an adequate diagnosis without having blood tests done. Correspondingly, they said they would not be satisfied if they didn't get what they expected; they described their dissatisfaction using expressions like 'feeling let down', 'no confidence' and 'not listening to me'.

(14402, woman, 45 years)

'She would have to be pretty convincing about her reasons for not doing it ... I'm sure blood tests are not always necessary, but I would expect further examinations'.

\section{Discussion}

Patients who would like to have their blood tested when they go to their GP tend to have high hopes for blood tests as a diagnostic tool: they assume that such tests yield a great deal of information, that they provide proof of a good health status and that they allow serious diseases to be detected at an early stage without mistakes. When these patients consult their GP, they expect him or her to take an active approach, particularly for complaints for which the doctor is unable to establish a diagnosis as yet. Apparently, according to patients tests are important to provide certainty in situations when the GPs are not capable of providing this certainty themselves. Patient expectations are influenced by opinions of people in their social environment, experiences with serious 
illnesses among relatives and acquaintances and media information about diseases. Patients in our study often do not appreciate a wait-and-see policy, although a clear explanation by GPs may in some cases make it acceptable to delay diagnostic testing. Patients also reported that they do not like it when their wishes are not met. Patients who have experienced a particular complaint before expect blood tests to be repeated when a new episode of the complaint occurs.

A valuable aspect of our study is that we interviewed patients at a time when they had an active desire to have blood tests done, that is, in the GP's waiting room prior to consultation. We thus collected data not about hypothetical situations but about patients' actual feelings in the real situation. The disadvantage of this timing of the interviews is that we had no time to collect patient details on which we could base a further purposive sampling strategy. As a result we might have missed a few diverging opinions. The $71 \%$ of patients who were willing to participate are comparable with the non respondents with respect to sex. This is in line with our impression that response mainly depended on the recruitment strategy. Recruitment by the practice assistant when the patient arrived in the practice yielded a response of almost $100 \%$, while recruitment by the interviewer in the waiting room appeared to depend on the reaction of the first patient: if positive most other patients were also willing to participate, if negative other patients refused as well. We intended to interview all patients who answered on the questionnaire that they maybe or surely wanted to have their blood tested. The aim of the study was to get insight in ideas of patients who did want blood testing in the consultation that day. Therefore this study may not yield a full overview of the determinants of patients' preference for blood tests, since we did not interview people who did not want blood tests to be done at the time. Not all patients who were eligible were actually interviewed. The main reason for this was a lack of capacity of the interviewer so we do not expect this caused biased results. Six patients appeared to have misunderstood the questionnaire. They did not have a current desire for blood testing on the day of interviewing but would like to be tested some day. Therefore they could not elaborate on the attitudes underlying their desire. In addition, assuming that among the patients who have not been interviewed some also misinterpreted the question, the proportion of patients expecting desiring to be tested diminishes to approximately $20 \%$. Since the interviews were treated anonymously, the risk of socially desirable answers was probably small, as is also suggested by the critical remarks made by the respondents. However, triangulation is needed to test the validity of the study's results.

Our findings are in line with the percentages of patients preferring blood testing as mentioned in the literature ${ }^{12-16}$. The perception among GPs that a relevant proportion of their patients, namely about a quarter, do expect blood tests to be 
done is confirmed. This group wants to be reassured and attaches great, almost magical value to these tests ${ }^{5}$. Kravitz et al. also found that patients mention both diagnostic and 'symbolic', to enrich the physician-patient relationship, purposes of testing ${ }^{19}$. An explanation of the great value of tests is that patients see medical techniques as a 'crystal ball' and as an addition to physicians' physical examination skills. Rhodes et al. found that diagnostic tests are important to confirming and normalising patients' symptoms, due to historical and cultural factors and the concreteness of the tests, especially when physicians can not locate the problem or are unsure about a solution. They add that patients in that case feel that their complaints are disconfirmed, which may explain the negative expressions of patients we found, if GPs would not order the tests that the patients expected ${ }^{21}$. Our study has revealed a dilemma. The principles of evidence-based medicine require GPs to use their expertise to strike a balance between patients' clinical status and personal circumstances, scientific evidence and the patients' preferences ${ }^{22}$. While the clinical status would often allow fewer diagnostic blood tests to be ordered, and scientific research shows that unnecessary diagnostics have unfavourable consequences, our study shows that many patients still prefer to have blood tests done ${ }^{23}$. Patients do not possess the necessary medical knowledge to make a well-founded choice. The obvious conclusion would be to develop relevant methods to educate patients in this respect, including an explanation of the limitations of supplementary diagnostics. However, as soon as patients have understood and accepted this message, doctors will no longer have the opportunity to use blood tests as a 'magic instrument'. It may be questioned whether this would be a favourable development for patients. On the other hand, deliberately withholding certain types of information from patients could be seen as a paternalistic approach.

\section{Conclusion}

The dilemma of either informing patients about the limitations of tests versus leaving their high expectations of test qualities intact shows that GPs will have to balance the benefits of reassuring their patients by means of blood tests which may be unnecessary against the benefits of avoiding unnecessary tests. By carefully ascertaining the precise nature of patients' request for help, GPs may be able to avoid this difficult choice for a proportion of patients, namely those who will not insist on having blood tests done. This should result in a scenario involving both satisfied patients and a rational diagnostic policy. Further quantitative research is required into (1) the non-diagnostic effects of supplementary blood tests, to allow the advantages and disadvantages of ordering such tests to be balanced and (2) into giving to or withholding from patients information about the limitations of tests. 


\section{References}

1. Winkens RAG. Rationele aanvullende diagnostiek door de huisarts. [Rational additional diagnostic testing by general practitioners]. Maastricht: Universiteit Maastricht; 1997.

2. Hindmarsh JT, Lyon AW. Strategies to promote rational clinical chemistry test utilization. Clin Biochem 1996;29:291-9.

3. Dinant GJ, van Wijk MAM, Janssens HJEM, Somford RG, de Jager CJ, Beusmans GHMI, Dijkstra RH, Wiersma Tj. NHG-standaard bloedonderzoek. Algemene principes en uitvoering in eigen beheer. [Dutch College of General Practitioners guideline 'Blood testing. General principles and use by GP']. Huisarts Wet 1994;37:202-11.

4. Suarez Almazor ME, Gonzalez Lopez L, Gamez Nava Jl, Belseck E, Kendall CJ, Davis P. Utilization and predictive value of laboratory tests in patients referred to rheumatologists by primary care physicians. J Rheumatol 1998;25:1980-5.

5. van der Weijden $T$, van Bokhoven MA, Dinant G-J, van Hasselt CM, Grol RPTM. Understanding laboratory testing in diagnostic uncertainty: a qualitative study in general practice. Br J Gen Pract 2002;52:974-80.

6. Hartley RM, Epstein AM, Harris CM, McNeil BJ. Differences in ambulatory test ordering in England and America. Role of doctors' beliefs and attitudes. Am J Med 1987;82:513-7.

7. Prochazka AV, Lundahl K, Pearson W, Oboler SK, Anderson RJ. Support of evidence-based guidelines for the annual physical examination. A survey of primary care providers. Arch Intern Med 2005;165:1347-52.

8. Jung HP, van Horne $F$, Wensing $M$, Hearnshaw $H$, Grol R. Which aspects of general practitioners' behaviour determine patients' evaluations of care? Soc Sci Med 1998;47: 1077-87.

9. Jung HP, Wensing M, Grol R. What makes a good general practitioner: do patients and doctors have different views? Br J Gen Pract 1997;47:805-9.

10. Peck BM, Ubel PA, Roter DL, Goold SD, Asch DA, Jeffreys AS, Grambow SC, Tulsky JA. Do unmet expectations for specific tests, referrals, and new medications reduce patients' satisfaction? J Gen Intern Med 2004;19:1080-7.

11. Britten N, Stevenson FA, Barry CA, Barber N, Bradley CP. Misunderstandings in prescribing decisions in general practice: qualitative study. BMJ 2000;320:484-8.

12. Williams S, Weinman J, Dale J, Newman S. Patient expectations: what do primary care patients want from the GP and how far does meeting expectations affect patient satisfaction? Fam Pract 1995;12:193-201.

13. Marple RL, Kroenke K, Lucey CR, Wilder J, Lucas CA. Concerns and expectations in patients presenting with physical complaints. Frequency, physician perceptions and actions, and 2week outcome. Arch Intern Med 1997;157:1482-8.

14. Cohen O, Kahan E, Zalewski S, Kitai E. Medical investigations requested by patients: how do primary care physicians react? Fam Med 1999;31:426-31.

15. Froehlich GW, Welch HG. Meeting walk-in patients' expectations for testing. Effects on satisfaction. J Gen Intern Med 1996;11:470-4.

16. van der Weijden $T$, van Velsen M, Dinant GJ, van Hasselt CM, Grol RPTM. Unexplained complaints in general practice. Prevalence, patients' expectations, and professionals' testordering behavior. Med Decis Making 2003;23:226-31.

17. van der Voort HPM, Grundmeijer HGLM, Hendrick JMA. NHG-NIPO-enquête 'Huisarts en zinvol handelen'. [Dutch College of General Practitioners-Dutch Institute for Public Opinion and Market Research-survey 'General practitioner and meaningful performance']. Huisarts Wet 1995;38:351-4.

18. O'Malley PG, Greenland P. The annual physical. Are Physicians ans patients telling us something. Arch Intern Med 2005;165:1333-4.

19. Kravitz RL, edward JC. Patients' perceptions of omitted examinations and tests. A qualitative analysis. J Gen Intern Med 2000;15:38-45. 
62 Chapter 3

20. Salmon P. Patients who present physical symptoms in the absence of physical pathology: a challenge to existing models of doctor-patient interaction. Patient Educ Couns 2000; 39:105-13.

21. Rhodes LA, McPhillips-Tangum CA, Markham $C$, Klenk $R$. The power of the visible: the meaning of diagnostic tests in chronic back pain. Social Science \& Medicine 1999; 48:1189-203.

22. Haynes RB, Devereaux PJ, Guyatt $G H$. Clinical expertise in the era of evidence-based medicine and patient choice. Evid Based Med 2002;7:36-8.

23. Swaak AJ. De klinische betekenis van het aantonen van antikernantistoffen. [Diagnostic significance of antinuclear antibodies]. Ned Tijdschr Geneesk 2000;144:585-9. 


\section{Chapter 4}

Designing a quality improvement intervention: a systematic approach

MA van Bokhoven, G Kok, T van der Weijden

Qual Saf Health Care 2003:12:215-220

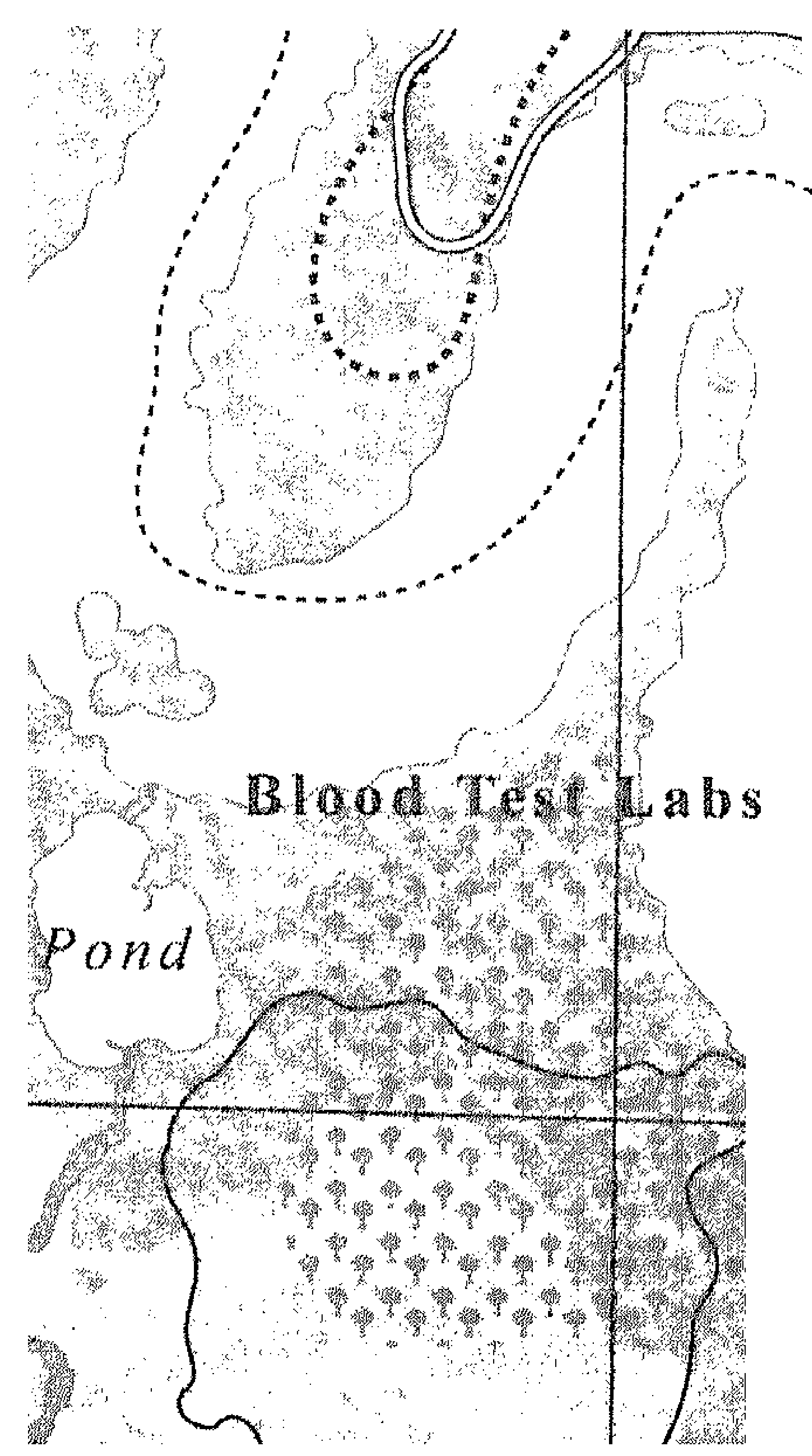




\section{Abstract}

Currently, most quality improvement or change management interventions are designed intuitively and their results are often disappointing. While improving the effectiveness of interventions requires systematic development, no specific methodology for composing intervention strategies and programs is available. This paper describes the methodology of systematically designing quality of care improvement interventions, discussing the problem analysis, intervention design and pre-tests. Several theories on quality improvement and change management are integrated and valuable materials from the area of health promotion are added. One method of health promotion in particular, Intervention Mapping, is introduced and applied. It describes the translation of knowledge about barriers to and facilitators of change into a concrete intervention program. The design of an intervention to improve general practitioners' (GPs') test ordering behaviour is used as an example. Systematic development of interventions, although time-consuming, appears to be worthwhile. Decisions that have to be made during the design process of a quality improvement intervention are visualised, allowing them to serve as a starting point for a systematic evaluation of the intervention. 
Designing a quality improvement intervention $\mid 65$

\section{Introduction}

Many different interventions have been developed to enhance the implementation of research findings or innovations in daily practice and to change professional or team performance. The Cochrane Effective Practice and Organization of Care group (EPOC group) summarized their effects in several reviews and concluded that the effectiveness of most interventions is heterogeneous and limited, although combined and multifaceted efforts are generally more promising ${ }^{1,2}$. Explanations for these disappointing results include the difficulty of changing existing practice, non-optimal choices of intervention strategies and the use of inadequate methods to design and evaluate interventions ${ }^{3-5}$. The use of rigorous research methods in quality improvement has now been generally accepted for evaluation of interventions, and more and more also for the problem analysis of the health care topic that is to be changed. However, a scientific approach should also be accepted for the design process of the intervention. In the current situation, many developers of interventions tend to select their strategies intuitively, usually based on their familiarity with a specific strategy. Often, the choice of the format of an intervention precedes the choice of its contents. However, it is generally accepted that, to be effective, interventions should be targeted at specific barriers to and facilitators of change ${ }^{4,6,7}$. Systematic development of interventions and tailoring their content and format to the specific features of target group and setting seems necessary to improve the effectiveness of patient care.

Steps to improve quality of care have been described as a cyclic process, which is summarised in Figure $4.1^{6,8,9}$. While the problem analysis step has been specified in the literature by several authors ${ }^{6,10,11}$, the literature on quality improvement research so far provides little information on the systematic translation of knowledge about barriers to and facilitators of change into concrete quality improvement interventions. This paper focuses on the methodology of designing and pre-testing such interventions. It addresses the question of how to link an intervention to the target problem in a transparent way. Several theories are described in this paper, both from the field of quality improvement and change management and from that of health promotion. As an example, we use a quality improvement project on the problem of unnecessary laboratory test ordering by general practitioners (GPs) in cases of medical uncertainty for which we have developed an intervention. 


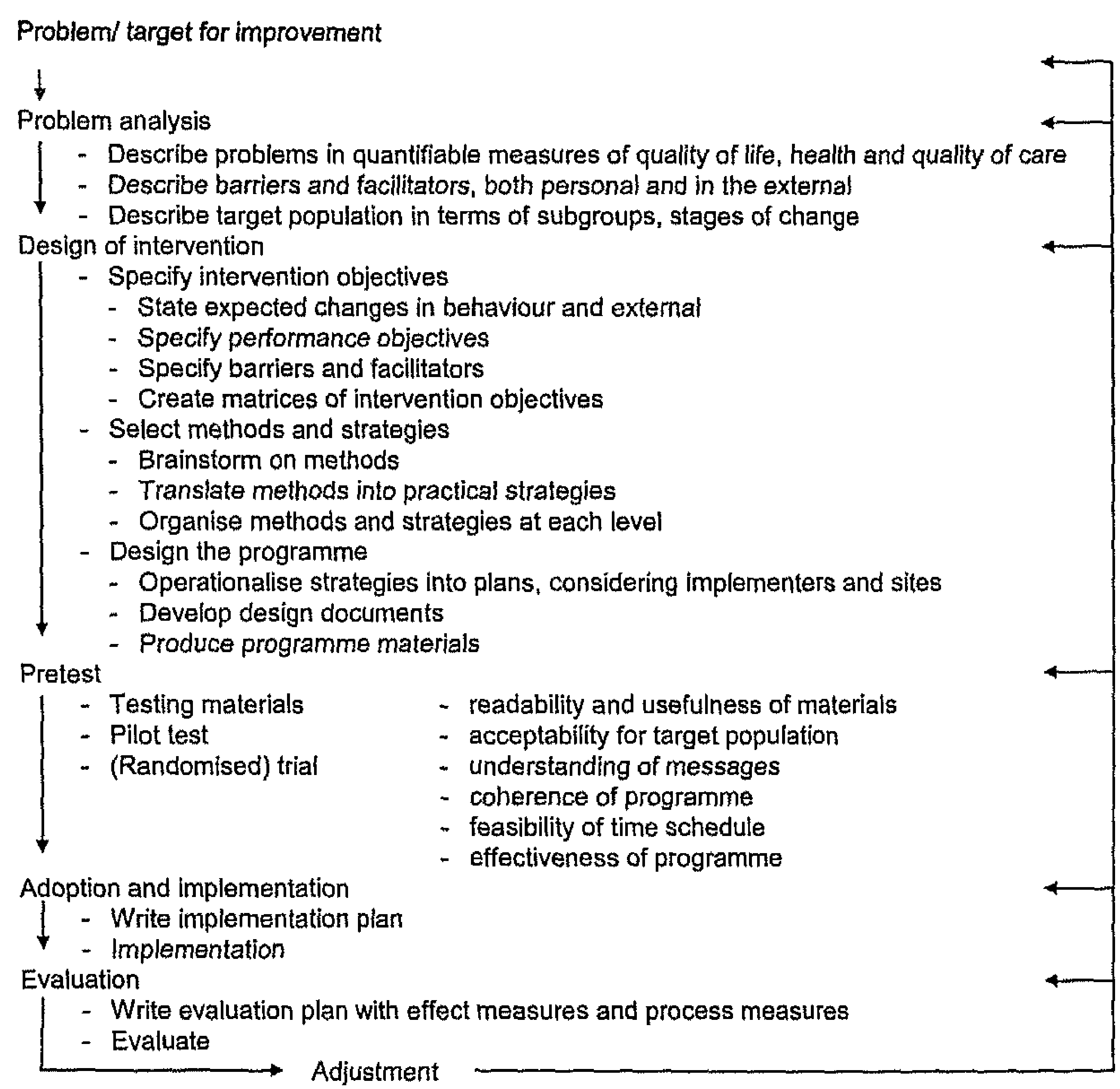

Figure 4.1 Design process for quality of care improvement interventions.

\section{Problem analysis}

Ideally, a problem analysis precedes the design of an intervention. This analysis begins with describing the health care problem that is to be addressed in quantifiable measures, followed by describing the barriers to and facilitators of change and ends with describing the target population.

Careful targeting of the intervention requires that the situation that is to be improved by the intervention is very clear. Several methods are available for the collection of data on 1) processes, 2) outcomes and 3) costs. It is advisable to take small but representative samples of professionals, patients, or written data, to use both quantitative and qualitative designs, and to fit the measurements into daily routines as much as possible ${ }^{12}$. The ultimate goal of every intervention is to improve the health and quality of life of patients or to maintain high standards of quality at lower costs. The intended improvement of health, quality 
of life and quality of care should therefore be described in quantifiable terms, and standards of good quality of care should have been set ${ }^{13,14}$.

In the process of tailoring the intervention the next step is to identify barriers to and facilitators of change. Figure 4.2 presents a modified, combined model based on the PRECEDE-PROCEED concept and the theory of planned behaviour ${ }^{15,16}$, showing different types of potential barriers and facilitators and the way they can influence professional behaviour and quality of life. Barriers and facilitators may be located within the person of the professional or in his or her external context ${ }^{7}$. Factors inherent in the professional, such as attitudes, perceived social influence and self-efficacy, stimulate the intention to change, while skills are needed for actual change. Context factors can have different levels. External influence can come from other individuals (interpersonal level), e.g. a patient requesting therapy, but also from a larger group such as a nursing team (organisational level), a local professional society (community level) or a whole nation (societal level), e.g. through legislation or insurances. Major factors at the organisational level include the organisation's mission, goals, policies, procedures, structures, technologies, physical setting, collaboration and resources ${ }^{17,18}$. At the community level, barriers and facilitators include collective self-efficacy, political efficacy and motivation to act ${ }^{19}$. At the societal level changes take place through political influence. Factors influencing the political decision process include the place where policies are made, whether outside or within the government or within the government but requiring support from outside for passage ${ }^{20}$, and groups influencing the policy makers, e.g. professional societies or patient groups ${ }^{21}$. The barriers and facilitators at different levels can be identified by detailed qualitative analysis of a few situations, followed by quantitative studies among professionals, patients and institutions to find out the relative importance of the various factors. Such studies can use questionnaires, interviews and observations ${ }^{22}$.

A third component of the problem analysis is the description of the target population in terms of aspects influencing the change process, such as the information channels they use. An aspect of the target population that needs to be clarified is the "stage of behavioural change". Behavioural changes in individuals (both at the personal and the interpersonal level) usually take place in a particular order ${ }^{10,11,23,24}$. Prochaska mentions five stages: (1) Precontemplation: the target population is not aware that their behaviours should and can be improved; (2) Contemplation: the target population reflects on the advantages and disadvantages of changing their behaviours; (3) Preparation: concrete plans for change are made; (4) Action: changing behaviour starts and (5) Maintenance: the target population decides whether to continue the new behaviour or to relapse to the former behaviour. Each stage sets specific goals for interventions: drawing attention to the message in stage 1, understanding the message in stage 2 , changing barriers and facilitators in stage 3 , changing 
behaviour in stage 4 and maintaining behaviour in stage 5 . Subgroups within the target population may have different characteristics and therefore require different interventions.

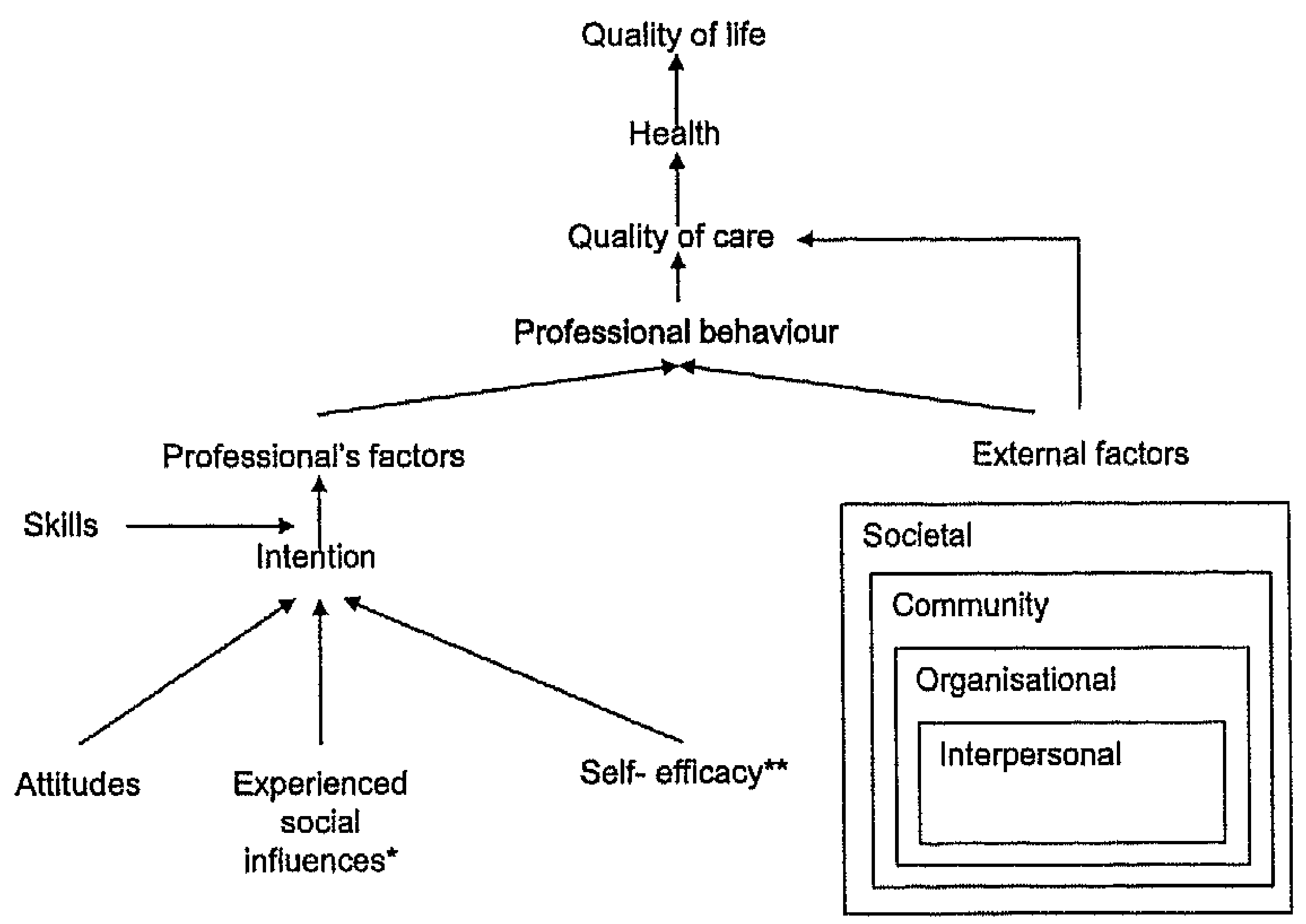

Figure 4.2 Model of barriers and facilitators.

* Subjectively perceived social influences (as opposed to interpersonal external factors, which are objective social influences); ${ }^{* \star}$ Trust in own capacities to perform according to standards of good care.

Change at the organisational level also seems to take place in a particular order. Goodman et al. ${ }^{17}$ distinguish between seven stages: (1) Noticing a problem, (2) Search for possible responses, (3) Evaluation of alternatives, (4) Decision to adopt a course of action based on a selected number of responses, (5) Initiation of action within the system, which requires policy changes and resources necessary for implementation, (6) Implementation, including some organisation members changing their work behaviours and relationships, (7) Institutionalisation of the change, which means including it in strategic plans, job descriptions and budgets so it becomes a routine part of organisational operations. Such distinctions between stages of change may be very important to know, as the key actors at which the intervention is targeted can vary depending of the stage of change $e^{25}$. Thus, senior level staff for instance is the target population in the earlier stages, where decisions are made to start the change process, and at the final stage, where the decision is made whether to institutionalise the change or not. Mid-level staff is important during the adoption 
Designing a quality improvement intervention $\mid 69$

and early implementation stages, in which skills to introduce procedures and provide training on the innovation are critical. In the adoption stage, the people who have to apply the change in their daily professional practice form the target population of the intervention.

An example of a problem analysis is given in Box 4.1.

\begin{abstract}
General practitioners frequently see patients with unexplained complaints. The complaints are usually self-limiting and the value of blood testing is nil, due to the low pre-test probability of disease. For this reason, a national guideline recommends to postpone blood testing in this category of patients by a month. Nevertheless, many GPs request several blood tests immediately, which might have negative effects such as unnecessary further investigations, fear in patients, somatisation and high costs. The goal of the intervention is to stimulate GPs to adhere to the national guideline.
\end{abstract}

$A$ qualitative study was performed to collect information on the barriers and facilitators influencing the test requesting behaviour. Consultations by the GPs were observed and field notes were taken on a pre-structured form. Afterwards, GPS were interviewed about barriers to and facilitators of test ordering behaviour for 'unexplained complaints' in a nonpre-structured way. This was followed by a search of the literature on possible barriers and facilitators. Next, a questionnaire survey was held among GPS which more specifically dealt with different types of barriers and facilitators, with questions on experiences with changing behaviour, opinions about the value of blood testing, perceived social influence from patients and colleagues or others on test ordering, grading their own capacities to change test ordering behaviour and interest in postgraduate education. GPs were also asked to rate their stage of change regarding consultation skills and test requesting behaviour. Since many GPS reported experiencing pressure from patients to do laboratory tests, a short questionnaire survey was held among patients in the waiting room, before they consulted their GPs. Patients were asked questions about what they thought their GPs could do for them. No further research was done at the other external levels, because successful interventions on test requesting behaviour at those levels had already been implemented before so we did not expect much room for improvement there. Besides, as many GPs work in one-person practices, the external level (organisational and societal) in Dutch general practice has less impact than e.g. in hospitals.

Some examples of barriers and facilitators found are presented below:

\begin{tabular}{|c|c|c|c|c|}
\hline Attitudes & $\begin{array}{l}\text { Perceived social } \\
\text { influences }\end{array}$ & Self-efficacy & Skills & External factors \\
\hline $\begin{array}{l}\text { - Blood testing } \\
\text { does not have } \\
\text { harmful effects } \\
\text { - Blood testing is } \\
\text { a more efficient } \\
\text { strategy than } \\
\text { explaining a } \\
\text { wait and see } \\
\text { policy }\end{array}$ & $\begin{array}{l}\text { - Patients expect } \\
\text { blood testing } \\
\text { - Patients are } \\
\text { anxious }\end{array}$ & $\begin{array}{l}\text { - Perceived } \\
\text { capability to } \\
\text { resist pressure } \\
\text { from patients } \\
\text { - Difficulty of } \\
\text { postponing } \\
\text { testing when } \\
\text { under pressure } \\
\text { of time }\end{array}$ & $\begin{array}{l}\text { - Routines (non- } \\
\text { conscious skills) } \\
\text { - Communication } \\
\text { skills } \\
\text { - Diagnostic skills } \\
\text { (doing laboratory } \\
\text { tests instead of } \\
\text { physical } \\
\text { examination) }\end{array}$ & $\begin{array}{l}\text { - Exaggerated } \\
\text { expectations of } \\
\text { tests among } \\
\text { patients } \\
\text { - Lack of } \\
\text { knowledge about } \\
\text { limitations of } \\
\text { tests among } \\
\text { patients }\end{array}$ \\
\hline
\end{tabular}

Box 4.1 Example of problem analysis ${ }^{31.34}$. 


\section{The actual design process}

Based on the findings of the problem analysis, the actual design process can start. The steps described below have been derived from the 'Intervention Mapping' theory, a method for designing interventions originally aimed at unhealthy behaviours ${ }^{26,27}$, that appeared to be helpful.

\section{Specification of performance and intervention objectives}

This step focuses on linking barriers and facilitators found in the problem analysis to concrete behaviours of professionals and on deriving objectives for quality improvement from this relation. It is always people who play a crucial role in managing change, even at the external level.

This step therefore begins with reframing both problem behaviours and external causes found in the problem analysis into desirable behaviours in practice: performance objectives, e.g. 'GP discusses a one-month wait and see policy in consultations with patients presenting unexplained complaints' or 'national college of GPs disseminates guideline to all GPs'. These performance objectives need to be specific and measurable in order to tailor the intervention to the heart of the problem and to be able to evaluate the effects of the intervention later. In addition, the frequency of the behaviours and the situations in which they should be performed are specifically described (See Box 4.2, first column). Goals may include not only changing behaviour but also maintaining behaviour $^{28}$. As a check it might be important to ask members of the target population and service providers, e.g. by means of interviews or questionnaires, whether they consider the objective important for achieving the improvement.

Achieving the performance objectives requires the barriers and facilitators to be influenced. Many barriers and facilitators are usually found, and since it is impossible to target an intervention to all of these, a selection has to be made. Two criteria for selecting barriers and facilitators are 'importance' and 'changeability'. If a barrier or facilitator is not important efforts to change it do not make sense, e.g. a wait and see policy of one month is cheaper than immediate blood testing in patients with unexplained complaints, as most complaints are self-limiting within one month. However, GPs consider costs only a minor factor in determining their behaviour. Therefore it is not useful to design an intervention providing information about costs to GPs. The same counts for changeability, e.g. GPs consider a lack of time per consultation as an important reason for requesting blood tests instead of explaining to patients the limited use of testing, the latter being more time consuming. The time scheduled per consultation, however, can hardly be changed as it is based on national rules. Sometimes information about importance and changeability can be extracted 
from the literature or from the quantitative research executed in the problem analysis phase.

\begin{tabular}{|c|c|c|c|c|}
\hline \multirow{2}{*}{\multicolumn{2}{|c|}{$\begin{array}{l}\text { Intervention objectives } \\
\text { (In cells) }\end{array}$}} & \multicolumn{3}{|l|}{ Barriers and facilitators } \\
\hline & & $\begin{array}{l}\text { High outcome } \\
\text { expectation of tests }\end{array}$ & $\begin{array}{l}\text { Lack of } \\
\text { communication skills }\end{array}$ & Uncertainty of GP \\
\hline \multirow{3}{*}{ 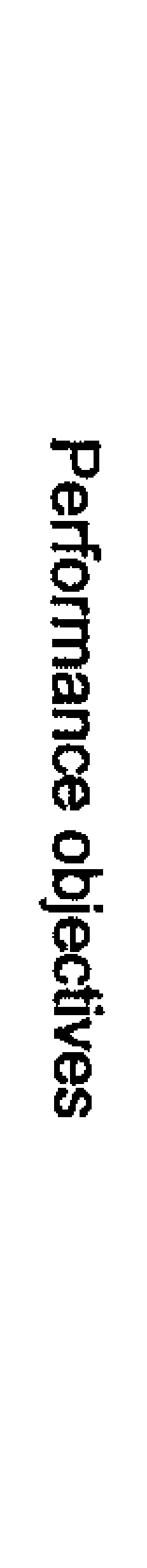 } & $\begin{array}{l}\text { Performs adequate } \\
\text { history taking and } \\
\text { physical examination }\end{array}$ & $\begin{array}{l}\text { GP states that } \\
\text { physical examination } \\
\text { is a way of taking } \\
\text { patients' complaints } \\
\text { seriously }\end{array}$ & $\begin{array}{l}\text { GP asks patients } \\
\text { about reasons for } \\
\text { encounter and } \\
\text { chooses formulation } \\
\text { which he/she feels } \\
\text { most comfortable with }\end{array}$ & $\begin{array}{l}\text { GP states that testing } \\
\text { does not yield more } \\
\text { information than } \\
\text { performing physical } \\
\text { examination }\end{array}$ \\
\hline & $\begin{array}{l}\text { Explains findings and } \\
\text { conclusions to patient } \\
\text { appropriately }\end{array}$ & $\begin{array}{l}\text { GP states the } \\
\text { importance of } \\
\text { explaining findings } \\
\text { and conclusions to } \\
\text { patient }\end{array}$ & $\begin{array}{l}\text { GP demonstrates the } \\
\text { use of different } \\
\text { formulations to } \\
\text { explain findings from } \\
\text { history taking and } \\
\text { physical examination } \\
\text { to patients }\end{array}$ & $\begin{array}{l}\text { GP shows patients } \\
\text { he/she is convinced } \\
\text { that findings from } \\
\text { history taking and } \\
\text { examination are } \\
\text { sufficient to feel } \\
\text { reassured }\end{array}$ \\
\hline & $\begin{array}{l}\text { Discusses a one- } \\
\text { month wait and see } \\
\text { policy }\end{array}$ & - & $\begin{array}{l}\text { GP uses instruction } \\
\text { materials in addition } \\
\text { to verbal message }\end{array}$ & $\begin{array}{l}\text { GP shows awareness } \\
\text { that his/her own } \\
\text { uncertainty is a } \\
\text { reason to request } \\
\text { blood tests }\end{array}$ \\
\hline \multicolumn{5}{|c|}{$\begin{array}{l}\text { In this example, only some of the barriers have been worked out. In addition, our problem } \\
\text { analysis revealed that patients have high pre-consultation expectations of laboratory tests and } \\
\text { demand tests, which influences the behaviour of GPs. Therefore the intervention was targeted } \\
\text { at the patients as well. As patients require a different intervention than GPs, their goals and } \\
\text { their barriers and facilitators were entered into a different matrix, which has not been depicted } \\
\text { here. As stated above, we decided not to target the intervention at other external levels. }\end{array}$} \\
\hline
\end{tabular}

Box 4.2 Example of part of a matrix with intervention objectives for GPs.

Performance objectives (Box 4.2, first column) and selected barriers and facilitators (Box 4.2, first row) can next be linked in a matrix, allowing a concrete intervention objective to be formulated in each cell of the matrix (Box 4.2, cells). E.g.: In order to achieve the goal of having GPs use adequate history taking and physical examination in practice (performance objective) the intervention should address barriers such as 'uncertainty of GP' so that as a result of the 
$72 \mid$ Chapter 4

intervention the GP 'states that laboratory testing does not yield more information than physical examination' (intervention objective). Like performance objectives, intervention objectives are formulated in terms of measurable behaviours. But intervention objectives are the aims of the intervention programme, rather than the aims of performance in daily practice. If the problem analysis reveals that there are target populations at more than one level or that different subgroups in the target population require different interventions, separate matrices should be drawn up for every group. Interventions may thus be targeted at different people or organisations, including assistants, patients, practice teams, hospital departments, politicians, insurance companies etc.

\section{Selection of methods and strategies}

Once such concrete intervention objectives have been defined, one can start searching for concrete methods and strategies for achieving these objectives. A good start is to have a brainstorming session in an expert group and make a provisional list of potential methods and strategies. Who is 'expert' depends on the problem for which an intervention is being developed and may include members of the target population. The list can be extended by a literature search, using resources like the EPOC database ${ }^{29}$. To enable a broad search, three approaches to searching literature databases are recommended:

1 By medical or health care subject, e.g. 'laboratory testing' or 'unexplained complaints'. The Cochrane Library includes several useful systematic reviews of interventions aimed at various topics ${ }^{29}$. Descriptive studies delineating variants of a service can also be of value ${ }^{3}$.

2 By concepts from the provisional list of methods and strategies or the barriers, facilitators and behavioural objectives from the previous step, e.g. 'explanation of findings to patients' or 'uncertainty'.

3 By known theories, e.g. goal setting theory or community organisation theory, or taxonomy of known strategies as used by the EPOC group. It is advisable to use this search strategy after the other strategies have been used, in order to enable a broad focus on a number of methods.

If it is not only the personal or interpersonal levels that are important, databases from business or political sciences can be used to extend the search. Overviews of methods can be found in several books and papers on health promotion, quality improvement and implementation of guidelines ${ }^{27,30}$. Objectives, methods and strategies found can now be listed, while the conditions under which they are effective can be added. Once sufficient methods have been collected, a selection can be made. (Box 4.3) 


\begin{abstract}
1. Brainstorming session: Strategies about skills training, such as stepwise explanation of complex skills, giving opportunities to practise both in a laboratory situation and in practice.

2. Literature search:

a. Search on 'unexplained complaints' and related topics such as 'irritable bowel syndrome', yielding papers on methods of cognitive behavioural therapy.

b. Search on concepts such as 'communication skills', adding methods such as 'providing knowledge about skills', 'attention to both skills and self-efficacy' and 'offering coping strategies for difficult situations.'

c. Search on general theories applicable to skills changes.' 'rewarding systems', 'goal setting theory' and 'giving feedback'.

3. Pragmatic selection of methods and strategies. Limiting conditions included the fact that group activities should take place in a safe environment, where one is allowed to make mistakes.
\end{abstract}

Box 4.3 Example of theories and strategies, illustrating the search for theories on test ordering skills and the related barriers and facilitators.

\title{
Programme design
}

The result of the previous step is a list of methods and strategies, which can be integrated into a coherent intervention. Basically, this asks for a creative process. Brainstorming about possible intervention components and materials may be a good start. Interesting materials may have come up during the search of the literature for methods and strategies. However, in translating the methods and strategies into intervention components, several conditions should be kept in mind, e.g. different "segments" of the target population may require different strategies, the stages of behavioural change in the target population and communication variables are important for the order and format of the components of the intervention ${ }^{24}$. Different stages of the change process may require different messages and different modes of transmission. According to McGuire ${ }^{24}$ interventions should have a striking 'appearance' to attract attention, while actually getting people to change depends more on the cogency of the message.

Another important condition is the opportunity to implement the intervention in daily practice as mentioned by Grol et al. ${ }^{7}$. Limiting factors in this respect include budget, human resources, available time, existing intervention formats and characteristics of the organization that actually implements the intervention. 


\section{Pre-test}

Before the intervention can be implemented it is recommended to do a pre-test. Pre-tests can consist of several stages, each of which can reveal information that requires adjustment of the intervention programme. The first stage involves testing the separate materials, such as leaflets or course books. Such testing can be done by means of 'technical' methods like readability formulas and tests of understanding, or by asking experts and members of the target population to try out the materials and give their opinions, preferably using qualitative methods. A combination of approaches is advisable. The second stage involves running the intervention programme in a pilot group to test its coherence and the time schedule and to get an impression of its acceptability in the target population. Again, the evaluation of this stage should be done mainly by qualitative methods. The final stage before large-scale implementation involves testing the intervention for its effectiveness by means of small-scale implementation. The best method to evaluate its effectiveness is usually a randomised clinical trial. Variables can be extracted from the problem analysis, while process measures, e.g. those concerning participation rates, should also be collected at this stage.

\section{Discussion}

It is generally accepted that systematic development of quality improvement interventions is needed if such interventions are to be effective. Interventions should have the correct objectives, be targeted at the barriers and facilitators related to achieving the desired performance and have programme components and materials adapted to specific objectives, target populations, barriers and facilitators. In addition, it may be necessary to target the intervention not only at individual professionals but also at external factors, which influence professional behaviour and the quality of care. The approach is ideally theory-driven. Several authors have described phases of the intervention design process, e.g. Green and Kreuter describe a problem analysis (PRECEDE) and evaluation (PROCEED) of interventions ${ }^{15}$. McGuire describes the requirements of educational messages and materials given the stage of the change process ${ }^{24}$. However, no integrated approach to the design process from the perspective of the intervention designer, linking problem analysis, programme design and pretest and specifying the programme design phase has as yet been provided. Bartholomew et al. have done interesting work on this topic in the field of health promotion, developing Intervention Mapping, a systematic method to link problem analysis, programme design and evaluation and to integrate theories and scientific evidence in the design process. It also visualises the 'crossroads' 
Designing a quality improvement intervention $\mid 75$

at which choices about the route to be followed have to be made. This method seems to be applicable in designing quality of health care improvement interventions as well. Designing such interventions is an iterative process, in which the designers go back and forth through the steps of problem analysis, design and pre-testing. Throughout the process, information becomes available which influences previous steps or lack of knowledge is revealed which requires additional study.

Going through the steps of such an intervention design can be difficult and timeconsuming. It requires study, creativity, expertise from social sciences and close cooperation between project group members, target population, materials designers and implementers. A pragmatic balance should be sought between collecting information and constructing the intervention. However, given the fact that interventions are often not or not very effective, the investment in carefully preparing, designing and testing such an intervention may be worthwhile.

It is important to involve future users of the intervention in the design process from the start. Writing an evaluation plan is easy after one has proceeded through the previous steps. As all goals have been formulated in measurable entities, measures for evaluation follow directly from the problem analysis and matrices. Besides, choices of barriers and facilitators, theories and formats have been explicitised, so that the effects of the intervention can be linked to these in the process evaluation. The choices made might explain unexpected effects and in the meantime offer ideas for adjusting the intervention.

Naturally, the selection criteria used during the intervention design process, e.g. for barriers and facilitators, methods, strategies, formats and materials, are still mainly pragmatic and several methods are mainly theory based, so further empirical research is needed to develop more evidence-based selection criteria and to test promising theories in practice. But the systematic approach makes the intervention transparent.

We conclude that there are possibilities to systematically design quality improvement interventions. Intervention Mapping appears to be a useful method, not only for health education interventions but also for quality improvement interventions. 


\section{References}

1. Bero LA, Grilli R, Grimshaw JM, Harvey E, Oxman AD, Thomson MA. Getting research findings into practice: Closing the gap between research and practice: an overview of systematic reviews of interventions to promote the implementation of research findings. BMJ 1998;317:465-8.

2. Grimshaw JM, Shirran L, Thomas R, Mowatt G, Fraser C, Bero L, Grilli R, Harvey E, Oxman A, O'Brien MA. Changing provider behaviour: an overview of systematic reviews of interventions. Med Care 2001;39:112-45.

3. Campbell $M$, Fitzpatrick $R$, Haines $A$, Kinmonth $A L$, Sandercock $P$, Spiegelhalter $D$, Tyrer $P$. Framework for design and evaluation of complex interventions to improve health. BMJ 2000;321:694-6.

4. Davis $D A$, Thomson MA, Oxman AD, Haynes RB. Changing physician performance. $A$ systematic review of the effect of continuing medical education strategies. JAMA 1995; 274:700-5.

5. Wensing $M$, van der Weijden $T$, Grol R. Implementing guidelines and innovations in general practice: which interventions are effective? $\mathrm{Br} J$ Gen Pract 1998:48:991-7.

6. Grol R. Beliefs and evidence in changing clinical practice. BMJ 1997;315:418-21.

7. Grol RPTM. Implementing guidelines in general practice care. Qual Health Care 1992: 184-91.

8. Ovretveit J. A team quality improvement sequence for complex health problem. Qual Health Care 1999;8:239-46.

9. Langley G, Nolan K, Nolan T. The improvement guide. San Francisco: Jossey Bass publishers, 1996.

10. Rogers EM. Diffusion of innovations. 4 ed. New York, 1995.

11. Prochaska JO, Di Clemente $\mathrm{CC}$. The transtheoretical approach: crossing traditional boundaries of therapy. Homewood II. Dow Jones-Irwin. 1984.

12. Nelson EC, Splaine MaE, Batalden PB, Plume SK. Building measurement and data collection into medical practice. Ann Intern Med 1998;128:460-6.

13. Woolf SH. Practice guidelines, a new reality in medicine. II. Methods of developing guidelines. arch Intern med 1992;152:946-52.

14. Grimshaw JM, Eccles M, Russel I. Developing clinically valid practice guidelines. J eval clin pract 1995;1:37-48.

15. Green LW, Kreuter MW. Health promotion planning. An educational and environmental approach. 2 ed. Mountain View: Mayfield publishing company, 1999.

16. Kok GJ, de Vries $H$, Mudde AN, Strecher VJ. Planned health education and the role of selfefficacy: Dutch research. Health Education Research 1991;6:231-8.

17. Goodman RM, Steckler A, Kegler MC. Mobilizing organizations for health enhancement: Theories of organizational change. In: Glanz K, Lewis FM, Rimer BK, editors. Health behaviour and health education: theory, research and practice. 2 ed. San Fransisco: JosseyBass, 1997:287-312.

18. Fawcett SB, Paine-Andrews A, Francisco VT, Schultz JA, Richter KP, Lewis RK, Williams EL, Harris KJ, Berkley JY, Fisher JL, et al. Using empowerment theory in collaborative partnerships for community health and development. American Journal of community psychology 1995;23:677-97.

19. Minkler $M$, Wallerstein $N$. Improving health through community organization and community building. In: Glanz K, Lewis FM, Rimer BK, editors. Health behavior and health education: theory, research and practice. San Fransisco: Jossey-Bass, 1997:241-69.

20. Cobb RW, Elder CD. Participation in American politics: the dynamics of agenda building. Baltimore: Johns Hopkins University Press, 1983.

21. Laumann EO, Knoke $D$. The organizational state: Social choice in national policy domains. Madison: University of Wisconsin Press, 1987.

22. Pope $C$, Van Royen $P$, Baker R. Qualitative methods in research on healthcare quality. qual saf health care 2002;11:148-152. 


\section{Designing a quality improvement intervention ${ }_{77}$}

23. Fishbein $M$, Ajzen I. Belief, attitude, intention and behavior: an introduction to theory and research.: Reading, Mass, Addison Wessley, 1975.

24. McGuire WJ. Attitudes and attitude change. In: Lindzey, Aronson, editors. The handbook of social psychology. New York: Random House, 1985:233-346.

25. Miles MB, Huberman AM. Qualitative data analysis. An expanded sourcebook. Thousand Oaks: SAGE Publications Inc, 1994

26. Bartholomew LK, Parcel GS, Kok G. Intervention mapping: a process for developing theoryand evidence-based health education programs. Health Educ Behav 1998;25:545-63.

27. Bartholomew LK, Parcel GJ, Kok G, Gottlieb NH. Intervention mapping. Designing theory- and evidence-based health promotion programs: Mountain view, California, London, Toronto, 2001.

28. Marlatt GA, Gordon JR. Relapse prevention; Maintenance strategies in the treatment of addictive behaviors. New York: Guilford, 1985.

29. Bero L, Grilli R, Grimshaw JM, Mowatt G, Oxman A, Zwarenstein M. Cochrane Effective Practice and Organisation of Care Group. The Cochrane Library 2002(3).

30. Glanz K, Lewis FM, Rimer BK. Health behaviour and health education: Theory, research and practice. 2 ed. San Francisco: Jossey-Bass, 1997.

31. Zaat JO, Van Eijk JT, Bonte HA. Laboratory test form design influences test ordering by general practitioners in the Netherlands. Medical Care 1992; 30:189-98.

32. Winkens RAG. Improving test ordering in general practice. The effects of individual feedback. Rijksuniversiteit Limburg, 1994.

33. van der Weijden $T$, van Velsen M, Dinant $G J$, van Hasselt CM, Grol RPTM. Unexplained complaints in general practice. Prevalence, patient expectations, and the professional's test ordering behavior. Med Dec Making, 2003;23:226-31.

34. van der Weljden $T$, van Bokhoven MA, Dinant GJ, van Hasselt CM, Grol RPTM Understanding laboratory testing in diagnostic uncertainty: a qualitative study in general practice. Br J Gen Pract 2002;52:974-80. 


\section{Chapter 5}

Blood test ordering for unexplained complaints in general practice: the VAMPIRE randomised clinical trial protocol [ISRCTN55755886]

MA van Bokhoven. H Koch, T van der Weijden, RPTM Grol, PJE Bindels, GJ Dinant

BMC Fam Pract 2006;7:20

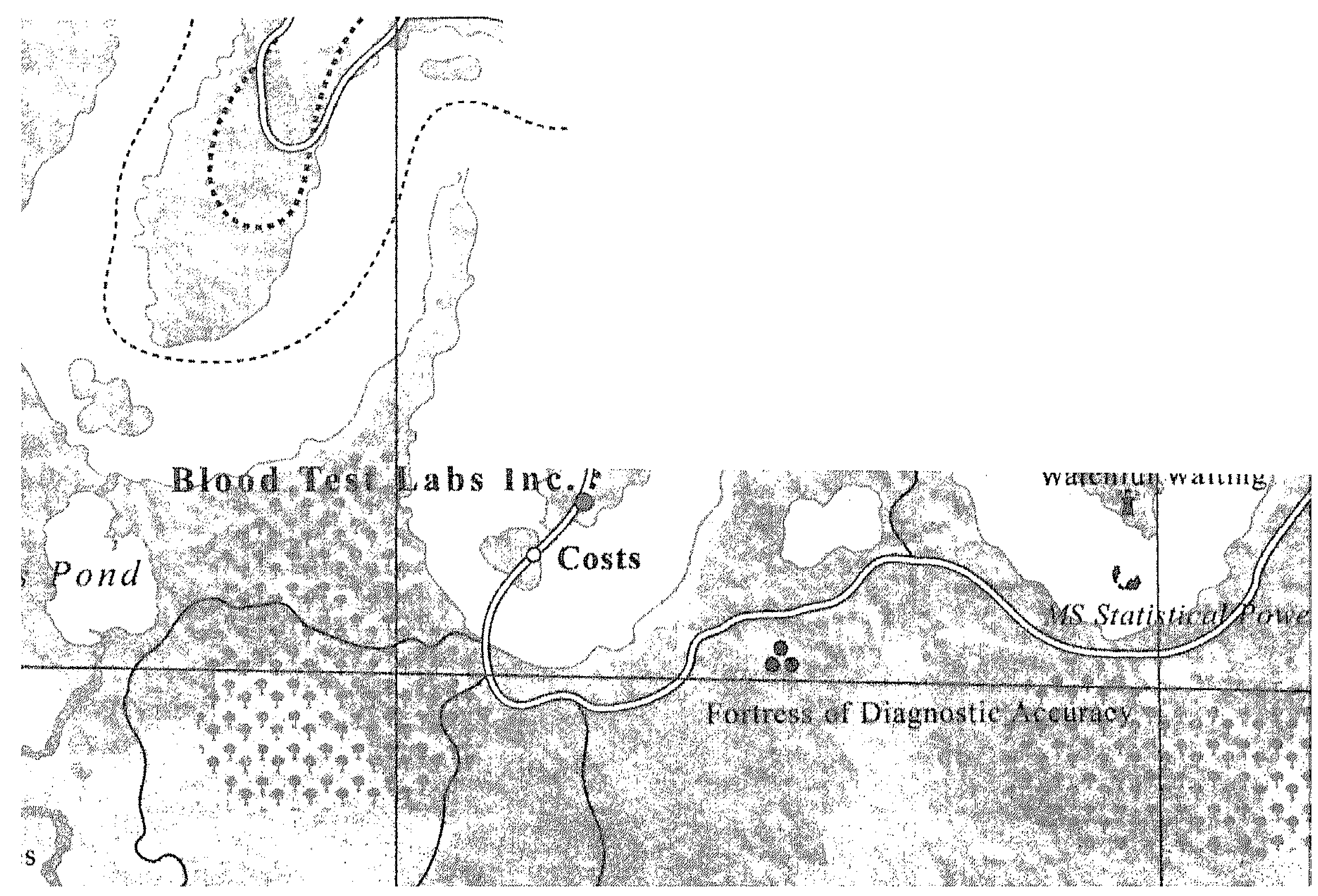


80 Chapter 5

\begin{abstract}
Introduction

General practitioners (GPs) frequently order blood tests when they see patients presenting with unexplained complaints. Due to the low prevalence of serious pathology in general practice, the risk of false-positive test results is relatively high. This may result in unnecessary further testing, leading to unfavourable effects such as patient anxiety, high costs, somatisation and morbidity. A policy of watchful waiting is expected to lower both the number of patients to be tested and the risk of falsepositive test results, without missing serious pathology. However, many general practitioners experience barriers when trying to postpone blood testing by watchful waiting. The objectives of this study are (1) to determine the accuracy of blood tests in patients presenting with unexplained complaints in terms of detecting pathology, (2) to determine the accuracy of a watchful waiting approach and (3) to determine the effects of a quality improvement strategy to promote the postponement of blood test ordering by GPs for patients with unexplained complaints.

Design

General practices are randomised over three groups. Group 1 is instructed to order blood tests immediately, group 2 to apply a watchful waiting approach and group 3 also to postpone testing, but supported by our quality improvement strategy. The trial consists of two sub-studies: a diagnostic study at patient level (group 1 versus groups 2 and 3 ) and a quality improvement study at GP level (group 2 versus group 3). The diagnostic strategy to be used involves of both customary and innovative tests. The quality improvement strategy consists of two small-group meetings and a practice outreach visit. Patient follow-up ends at 12 months after the initial consultation. Primary outcome measures are the accuracy and added value of blood tests for detecting pathology, the effect of a 4-week postponement of test ordering on the blood test characteristics and the quantity of tests ordered. Secondary outcome measures are the course of complaints, quality of life, satisfaction with care, anxiety of patients and practitioners, determinants of physicians' behaviour, health care utilisation and costs.
\end{abstract}

Discussion

The innovative aspect of this trial is that it combines a clinical-epidemiological study and a quality of care study. 
VAMPIRE randomised clinical trial protocol $\mid 81$

\section{Introduction}

\section{Unexplained complaints}

'Unexplained complaints' can be defined as: those complaints for which a general practitioner (GP), after clarifying the reason for encounter, taking history and performing physical examination, is unable to establish a diagnosis ${ }^{1}$. This definition reflects a broad continuum of clinical pictures, ranging from complaints of recent onset to more chronic situations in which the physician is convinced that somatic disease is absent. Newly presented unexplained complaints will in most cases be self-limiting, but they can also develop into chronic complaints, or might be the first sign of serious disease ${ }^{2}$. Since GPs are usually the first health care professionals patients present their complaints to, these complaints belong to the particular expertise of GPs, who are used to deal with this type of complaints autonomously, without referring the patients to hospital.

On average, $13 \%$ of consultations involve complaints considered unexplained by the $\mathrm{GP}^{3}$. Although only a small minority of these lead to chronicity or serious disease, additional diagnostic testing is often done after history taking and physical examination ${ }^{4,5}$.

\section{Blood test ordering}

It has frequently been suggested that immediate test ordering in unexplained complaints is superfluous ${ }^{6-8}$. Since the pre-test probability of serious pathology in patients with unexplained complaints is usually low, the risk of false-positive test results is relatively high. This may result in a chain of unnecessary further testing, which in turn might lead to patient anxiety, high costs, somatisation and a risk of serious side effects or even unnecessary morbidity ${ }^{9,10}$. Applying a watchful waiting approach is recommended because the majority of these complaints are expected to be self-limiting. Patients in whom the complaints are not self-limiting will have a higher prior probability of having serious pathology, and the diagnostic accuracy of tests in this selected group is expected to be higher, because of the lower risk of false-positive test results.

We have found only one guideline on blood test ordering for unexplained complaints in general practice. This guideline, issued by the Dutch College of General Practitioners (NHG), recommends an initial watchful waiting approach. If a complaint persists, it recommends ordering a limited number of tests (glucose, haemoglobin $(\mathrm{Hb})$, erythrocyte sedimentation rate (ESR) and thyroid stimulating hormone $(\mathrm{TSH}))^{1,11}$.

However, these test recommendations are based on theory and consensus rather than on evidence. Moreover, in practice, more blood tests are ordered, or the watchful waiting approach is not followed. Little is known about the accuracy 
or additional value of diagnostic blood tests or combinations of such tests, in addition to signs, symptoms and environmental and psychosocial factors, for the purpose of discriminating between self-limiting unexplained complaints and pathology. In addition, the accuracy of some newer tests, such as the carbohydrate deficient transferrin (CDT) test for the detection of pathology in patients with unexplained complaints in general practice, is not yet known ${ }^{12}$. Furthermore, several questions concerning the non-diagnostic effects of test ordering, e.g. on patient and doctor anxiety, remain unanswered. Apart from their diagnostic purposes, GPs frequently order tests for more strategic reasons, e.g. to prevent referral to a specialist or to make the psychosocial nature of complaints more acceptable to the patient, thereby anticipating normal blood test results ${ }^{11}$.

\section{Improvement of test ordering}

Though formal evidence is lacking, one can conclude from the high volume of tests ordered by GPs and the low probability of pathology that there is room for improvement to GPs' blood test ordering behaviour for patients presenting with unexplained complaints ${ }^{13,14}$. It is generally accepted that strategies to improve professionals' behaviour need to be developed systematically, based on barriers to and facilitators of the target behaviour ${ }^{15}$. Determinants of blood test ordering by GPs for patients with unexplained complaints include not only a lack of knowledge about the diagnostic value of blood testing but also practice routines, GPs' tolerance of uncertainty, experienced pressure from patients, tactical motives and the perceived need to reassure patients ${ }^{11}$. This means that a strategy aimed at reducing test ordering by professionals should not only focus on improving diagnostic knowledge but also on skills such as dealing with uncertainty and patient pressure and applying alternative modes to reassure patients. The different types of objectives require adequate and tailored methods of instruction, e.g. teaching a skill requires practising rather than lecturing only. Since patients also seem to play a role in the decision process to order tests, it may be valuable to focus a strategy on patients as well, in order to achieve greater effects.

\section{Objectives of the study}

The first objective of the ongoing study presented here is to determine the accuracy of diagnostic blood tests or combinations of such tests and their value, in addition to signs, symptoms and contextual factors, for the purpose of discriminating between self-limiting diseases and serious pathology in patients presenting with unexplained complaints. The second objective is to compare the accuracy of a watchful waiting approach with that of immediate test ordering. The third objective is to evaluate the effects of a systematically designed quality 
improvement strategy for GPs, aiming at the postponement of blood test ordering in patients with unexplained complaints.

\section{Research questions}

1. What is the course of complaints that are considered unexplained by GPS over a period of one year?

2. What is the diagnostic accuracy of blood tests, relative to and in addition to combinations of signs and symptoms, for the purpose of discriminating between self-limiting complaints and early stages of pathology in patients presenting with unexplained complaints?

3. What is the cost-effectiveness of a 4-week watchful waiting approach compared to immediate test ordering in patients presenting with unexplained complaints? 'Costs' in this respect include direct medical costs, absence from work and immaterial costs such as patients' uncertainty, satisfaction and quality of life.

4. What is the cost-effectiveness of a systematically developed strategy to improve GPs' test ordering behaviour, compared to merely instructing them to postpone testing?

\section{Cooperation}

The departments of General Practice of the University of Maastricht and of the Academic Medical Center-University of Amsterdam are cooperating in this study. Data collection ended on December 31, 2004. At the time of writing of this protocol article, we are engaged in data cleaning and analysis.

\section{Ethical approval and informed consent procedure}

\section{Ethical approval}

The medical ethics committees of both the Academic Medical Center-University of Amsterdam and the University Hospital Maastricht have approved the study.

\section{Informed consent procedure}

GPs hand out written information and an informed consent form to eligible patients. Patients are given the opportunity to read the information and think about participation before signing the consent form. Patients in group 1 are fully informed about the trial. Patients in groups 2 and 3 are kept naive about the possibility of immediate blood test ordering. This is because it is impossible to blind patients for the test group they are in (immediate or postponed blood test ordering). Bias could be caused by selective dropout of patients and by a Hawthorne effect, as patients can be expected to prefer immediate test ordering 
84 Chapter 5

over a watchful waiting approach. Patients in groups 2 and 3 are told that the study investigates the way their GPs manage patients with unexplained complaints.

\section{Design}

\section{Operationalisation of 'unexplained complaints'}

Of the complaints that are considered unexplained by GPs according to the definition drawn up by the Dutch College of General Practitioners (NHG), the following 5 were selected: fatigue, abdominal complaints, musculoskeletal complaints, itch and weight changes. These were selected on the basis of the following criteria: commonly seen unexplained complaints in general practice, frequent ordering of blood tests and the possibility that clinically relevant underlying diseases are detected by blood tests.

\section{Clustered randomised clinical trial}

Participating general practices are randomised over three groups (Figure 5.1). GPs in group 1 are instructed to order blood tests immediately at the first consultation. Those in group 2 are instructed to restrict blood test ordering to patients with complaints persisting after four weeks. GPs in group 3 are also instructed to try and postpone test ordering, but they also participate in a quality improvement strategy that supports them in postponing test ordering for patients with unexplained complaints. The study design includes two substudies. The first is a diagnostic study comparing patients from group 1 (immediate test ordering) with patients from groups 2 and 3 (four weeks of watchful waiting). The second is a quality improvement study, comparing group 2 (instruction to postpone test ordering) with group 3 (instruction to postpone test ordering plus quality improvement strategy) in terms of the actual postponement of test ordering.

The reason why we decided to randomise general practices instead of patients or individual GPs is that we assumed there would be contamination, for three reasons. Firstly, it is not possible for GPs to selectively use the communication skills they have learnt during the quality improvement strategy in one patient and fall back to their previous behaviour in the next patient. Secondly, in group practices, patients are sometimes seen by different colleagues at different appointments. If these GPs are in different intervention arms, this may bias the results. Thirdly, patients of different GPs within one practice may exchange experiences about the scientific research project they participate in. The randomisation procedure is carried out separately for the two regions where the 
participating university departments are located. To achieve allocation concealment, study groups are assigned to GPs by a random number seed computer program that randomises in blocks and is operated by an experienced research assistant.

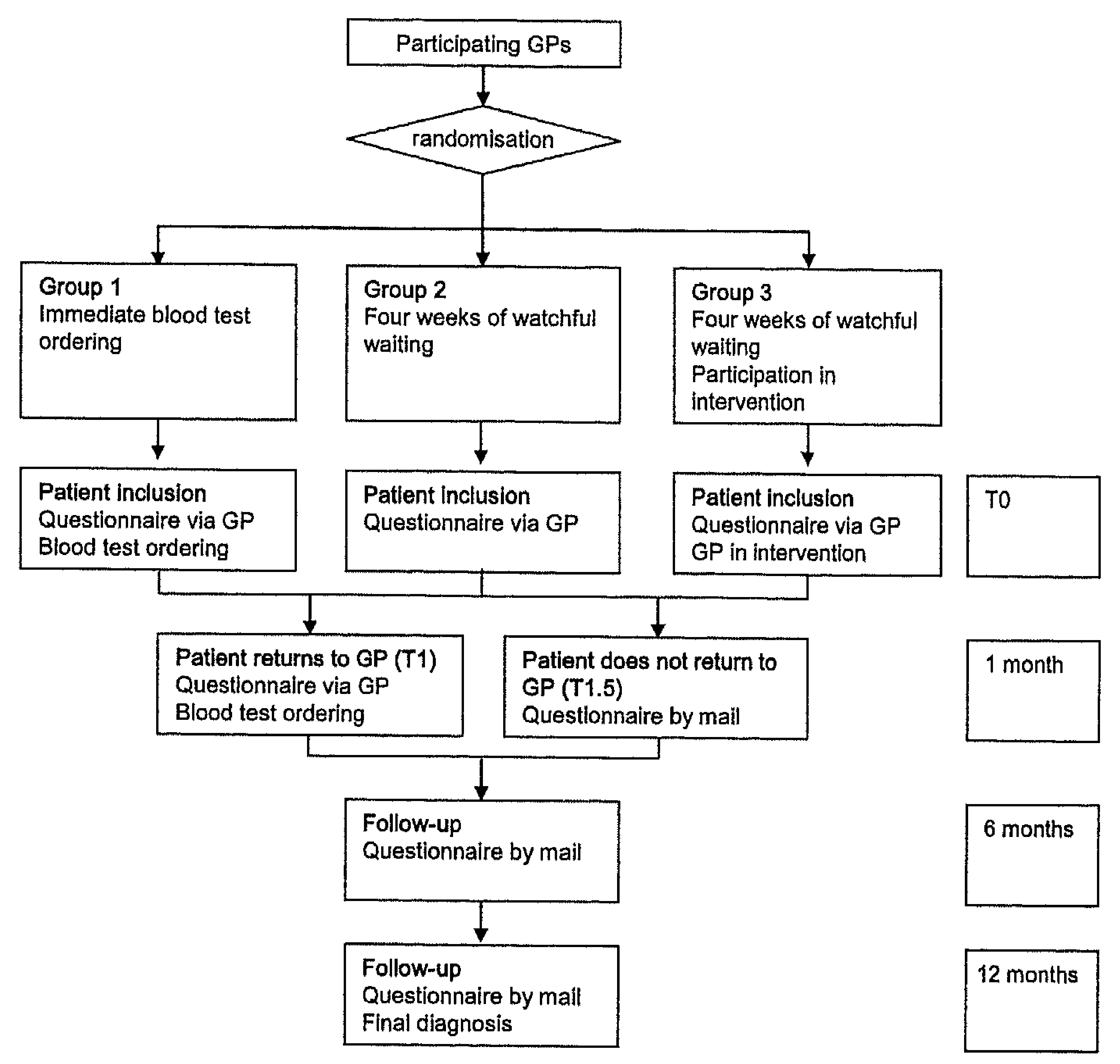

Figure 5.1. Randomisation scheme.

\section{Procedure}

If, after history taking and physical examination, a patient is considered to have unexplained complaints and gives informed consent, the GP enrols the patient in the study. Depending on the GPs study arm, blood test ordering or a 4-week watchful waiting approach is suggested to the patient. All patients are asked to return to the GP if complaints do not disappear within four weeks. If patients return, blood tests are ordered for every patient, irrespective of GPs' study arm. 
$86 \mid$ Chapter 5

This means that patients in group 1 are then tested for the second time and patients in groups 2 and 3 for the first time.

All tests are performed at the regional laboratory, according to local standard operating procedures and using the local reference values.

Patient follow-up ends at 12 months after the initial consultation.

\section{Power calculation}

Based on previous research, we estimated that approximately $2 \%$ of patients will eventually be diagnosed with serious pathology ${ }^{16}$. We estimated that 100 patients with pathology will be needed to allow valid conclusions, which means that 5000 patients should be included in the study. Dutch GPs see approximately 500 patients a month, of whom $1-5 \%$ are estimated to have unexplained complaints. This means that each GP could on average include 180 patients in one year. These figures mean that we need 27 GPs to participate. Assuming a patient refusal rate of approximately 50 percent, 54 GPs need to be recruited. A total of 5000 patients (approximately 1700 in each study group) would also be sufficient to determine the costs and effects of the quality improvement strategy with enough precision.

\section{Participants}

The project is being carried out in two regions in the Netherlands, one in the south and one in the west.

GPS

For logistic reasons, only GPs associated with certain laboratories for the handling of their test requests can participate in the trial. These laboratories are situated in the western (Haarlem, Almere) and southern (Sittard, Weert, Geldrop, Eindhoven, Helmond, Veldhoven, 's Hertogenbosch) regions. No further GP participation criteria were formulated.

\section{Patients}

Patients aged 18 years and older, presenting with one of the unexplained complaints mentioned above, who have not consulted their GPs for this complaint in the previous six months and who are able to speak, read and write Dutch are eligible to be included in the study. GPs decide to ask patients to participate in the study after history taking and physical examination, so the decision to label the complaints of a patient as unexplained is made entirely by the GPs. Excluded are patients with unexplained complaints for whom the GPs 
feel that watchful waiting would be unacceptable to them. Patients are asked to participate by their GPs. The GPs are asked to enrol each consecutive eligible patient.

\section{Blinding}

\section{Researchers}

The researchers are not blinded for the trial group allocation of the participating GPs. They are not involved in the GPs' decision to label patients as having unexplained complaints, nor in the test ordering procedure or the reporting of the results of the laboratory tests.

\section{GPS}

The GPs are not blinded for the trial group they are randomised to, but they are for the content and format of the quality improvement strategy that aims to support GPs in postponing test ordering. In addition, only those test results from the set of tests we decided to include in the study (see the section entitled 'Diagnostic intervention at patient level' below) they ordered themselves are fed back to them, so they are partially blinded to the test results. Since the effects of test results on the treatment given to patients and on their clinical course are outcome measures of our study, we do not aim at complete blinding to the test results.

\section{Patients}

Patients in group 1 are fully informed about the blood testing options, whereas patients from groups 2 and 3 are kept naive about the possibility of getting blood tests ordered. All patients are blinded for the possibility that their GP is participating in a quality improvement strategy. In our opinion, full blinding is not possible because there is no placebo for blood testing that is feasible and ethically acceptable.

\section{Laboratories}

Laboratories are blinded for all patient characteristics except sex and age.

\section{Diagnostic intervention at patient level}

\section{Selection of blood tests}

Members of an expert panel including GPs and hospital specialists $(n=20)$ have been individually asked to propose tests which they regarded as useful diagnostic tools in general practice for each of the five complaints. All tests 
$88 \mid$ Chapter 5

mentioned at least twice were included in a complaint-specific set of tests (Table 5.1). If not already included in the set, the four tests recommended in the NHG guideline (glucose, ESR, TSH and $\mathrm{Hb}$ ) were added. In addition, iron parameters (transferrin saturation (TS) and ferritin), anti-endomysium and carbohydrate deficient transferrin (CDT) were added as indicators of haemochromatosis, celiac disease and alcohol abuse respectively. These three diseases can lead to unexplained complaints, are frequently missed by GPS according to the literature and should be demonstrable with the above blood tests. The diagnostic accuracy of these tests in patients presenting with unexplained complaints in general practice has, however, not yet been established ${ }^{12,17-20}$.

Table 5.1 Sets of laboratory tests per complaint.

Fatigue Abdominal Musculo- $\begin{gathered}\text { Weight Itch } \\ \text { complaints } \\ \text { skeletal } \\ \text { complaints }\end{gathered}$
changes

Alkaline Phosphatase (AF)

Alanine aminotransferase (ALAT)

Amylase

Anti-endomysium

Aspartate aminotransferase (ASAT)

Bilirubin

Erythrocyte sedimentation rate (ESR)

Carbohydrate-deficient transferrin (CDT)

Creatinin kinase (CK)

Creatinin

C-reactive protein (CRP)

Differentiated leukocyte count

Eosinophils

Ferritin

Gamma glutamyl transferase (GGT)

Glucose

Haemoglobin $(\mathrm{Hb})$

Potassium (K)

Latex fixation test

Lactate dehydrogenase (LDH)

Leukocyte count

Monosticon

Total IgE

Thyroid stimulating hormone (TSH)

Transferrin saturation (TS)

Urea

\begin{tabular}{|c|c|c|c|}
\hline \multirow{2}{*}{$\begin{array}{l}x \\
x\end{array}$} & $x$ & & $x$ \\
\hline & $x$ & & $x$ \\
\hline \multirow{2}{*}{$x$} & $x$ & & $x$ \\
\hline & $\mathbf{x}$ & & $x$ \\
\hline$x$ & $x$ & & $x$ \\
\hline$x$ & $x$ & $x$ & $x$ \\
\hline \multirow[t]{2}{*}{$x$} & $x$ & & $x$ \\
\hline & & $x$ & \\
\hline \multirow[t]{2}{*}{$\mathbf{x}$} & $x$ & $\mathbf{x}$ & $x$ \\
\hline & $x$ & & \\
\hline$x$ & $x$ & & $x$ \\
\hline$x$ & $x$ & $x$ & $x$ \\
\hline$x$ & $x$ & & $x$ \\
\hline$x$ & $x$ & $x$ & $\mathbf{x}$ \\
\hline$x$ & $x$ & $x$ & $x$ \\
\hline \multirow{2}{*}{$x$} & & $x$ & \\
\hline & & $x$ & $y$ \\
\hline$\hat{x}$ & $x$ & & $x$ \\
\hline \multirow[t]{2}{*}{$x$} & & & \\
\hline & $x$ & & \\
\hline$x$ & $\mathbf{x}$ & $x$ & $x$ \\
\hline$x$ & $x$ & $x$ & $x$ \\
\hline
\end{tabular}

Total number of tests 
VAMPIRE randomised clinical trial protocol $\mid 89$

\section{Immediate blood test ordering}

GPs from group 1 are instructed to order blood tests immediately when including a patient in the study. The GPs are free to decide on the number and type of blood tests. The patient takes the blood test ordering form to the regional laboratory participating in the study. At the laboratory, the tests ordered by the GP are supplemented by the complaint-specific tests from the sets described in Table 5.1. Only results of tests ordered by the GPs themselves are fed back. If a GP does not intend to order any tests (but is obliged to do so by the study protocol), the results of the four tests recommended by the NHG guideline are fed back, because patients expect results after a blood sample has been taken.

\section{Watchful waiting for four weeks}

GPs from groups 2 and 3 propose to the patients they include to observe a 4-week watchful waiting approach. When watchful waiting is not considered feasible by the GP, e.g. because a patient insists on being tested, test ordering is allowed. In that case, the GPs are asked to state the reasons for not postponing test ordering on a special form.

\section{Reference standard}

The nature of unexplained complaints implies that no proper gold standard exists. Hence, we opted for a delayed type cross-sectional study design ${ }^{21,22}$. In this type of design, the diagnosis after the 12-month follow-up period is used as a reference standard. This diagnosis is established separately by two researchers, making use of information from the GPs' patient records. Differences are discussed and consensus is sought. If consensus cannot be reached, the case is presented to an expert panel that takes the final decision. No restrictions are imposed on GPs as to patient management during follow-up.

\section{Quality improvement strategy}

\section{Development of the strategy}

Determinants of blood test ordering for unexplained complaints - both those relating to the GPs and those relating to the patients - have been identified previously ${ }^{11,23}$. Based on these determinants, a quality improvement strategy has been developed using a systematic procedure based on intervention mapping techniques ${ }^{15}$. The strategy has been pilot-tested, after which slight adjustments were made based on the pilot results. 
90 Chapter 5

\section{Content of quality improvement strategy}

For each GP in group 3, the strategy consists of two small-group meetings and one outreach visit by the researchers to their practice. Table 5.2 provides more details on the content of the strategy. The first group meeting is led by a GP experienced in medical diagnostic decision-making and a behavioural scientist experienced in teaching communication skills, while the second meeting is tutored only by the behavioural scientist. The outreach practice visit is made by one of the researchers. We have also developed patient education leaflets and diaries, to be handed out by the GPs, and a video message about watchful waiting, to be shown in the waiting room. All materials have been developed by the research team.

Table 5.2 Elements of the quality improvement strategy.

Elements of strategy

Contents of programme Small group meeting 1

Part 1: Interactive explanation of diagnostic value of diagnostic testing for unexplained complaints and effect of watchful waiting approach on diagnostic value.

Part 2: Discussion of difficulties experienced in practice when dealing with patients presenting with unexplained complaints.

Goal setting to change behaviour in GPs' own practice.

Small group meeting 2

Part 1: Discussion about experiences with behaviour change.

Searching for solutions to barriers that have arisen.

Part 2: Practicing difficult situations by means of video vignettes.

Setting new goals to change own behaviour.

Practice visit

Discussing individuals' barriers to change and providing suggestions to overcome these, based on stage of change.

In between meetings, GPs get the opportunity to work on their goals to change their behaviour.

Materials

Course book.

Leaflets for patients with information about unexplained complaints.

Diaries about complaints and food intake to hand out to patients to fill in and later discuss together.

Video message for the waiting room, explaining the use of watchful waiting.

\section{Procedure}

At the beginning of the trial, all GPs in group 3 are invited to the small group meetings, which are organised regionally, usually at the regional hospital. These meetings are held with an interval of approximately four weeks. After these meetings, an appointment is made for the practice visit, which takes place 
VAMPIRE randomised clinical trial protocol $\mid 91$

at least three months after the second group meeting. GPs are encouraged to prepare for the meetings by doing homework assignments.

\section{Control group}

GPs in group 2 are the control group for GPs in group 3. In order to ensure a maximum contrast, no strategy is offered to group 2 .

\section{Measurements}

All measurement instruments, measurement times and variables are summarised in Table 5.3.

Most questions in the questionnaires have been formulated by the research team, based on topics found in the literature. Quality of life is measured by the RAND SF36, together with the thermometer of the Euroqol questionnaire. Both are widely used and have been validated extensively ${ }^{24-26}$.

\section{Patients}

Findings of history taking and physical examination are recorded on a prestructured complaint registration form by the GP after the consultation(s).

All patients are given the first questionnaire at the first consultation and a second questionnaire at the second consultation after four weeks. Patients who do not return to their GP after four weeks are sent a questionnaire by mail. Patients from all groups receive follow-up questionnaires by mail at six and twelve months after the initial consultation.

After twelve months, i.e. at the end of the follow-up period, data on the final diagnosis and health care consumption are collected from the patients' records by the researchers (MB and $\mathrm{HK}$ ).

Copies of test ordering and result forms are collected by the researchers (MB and $\mathrm{HK}$ ) from the regional laboratories.

\section{GPS}

Background data of all participating GPs are collected before the start of the patient inclusion process. Data on whether the GPs are satisfied with the consultation, whether they suspect serious pathology and whether they are certain about the diagnosis are collected from the complaint registration form. The GPs' test ordering behaviour is derived from the test ordering forms and the patient records. GPs in group 3 are asked to complete evaluation forms on process items of the quality improvement strategy. In addition, the determinants of their change processes they mentioned are audio-taped during the practice visit that is part of the quality improvement strategy. 
92 $\mid$ Chapter 5
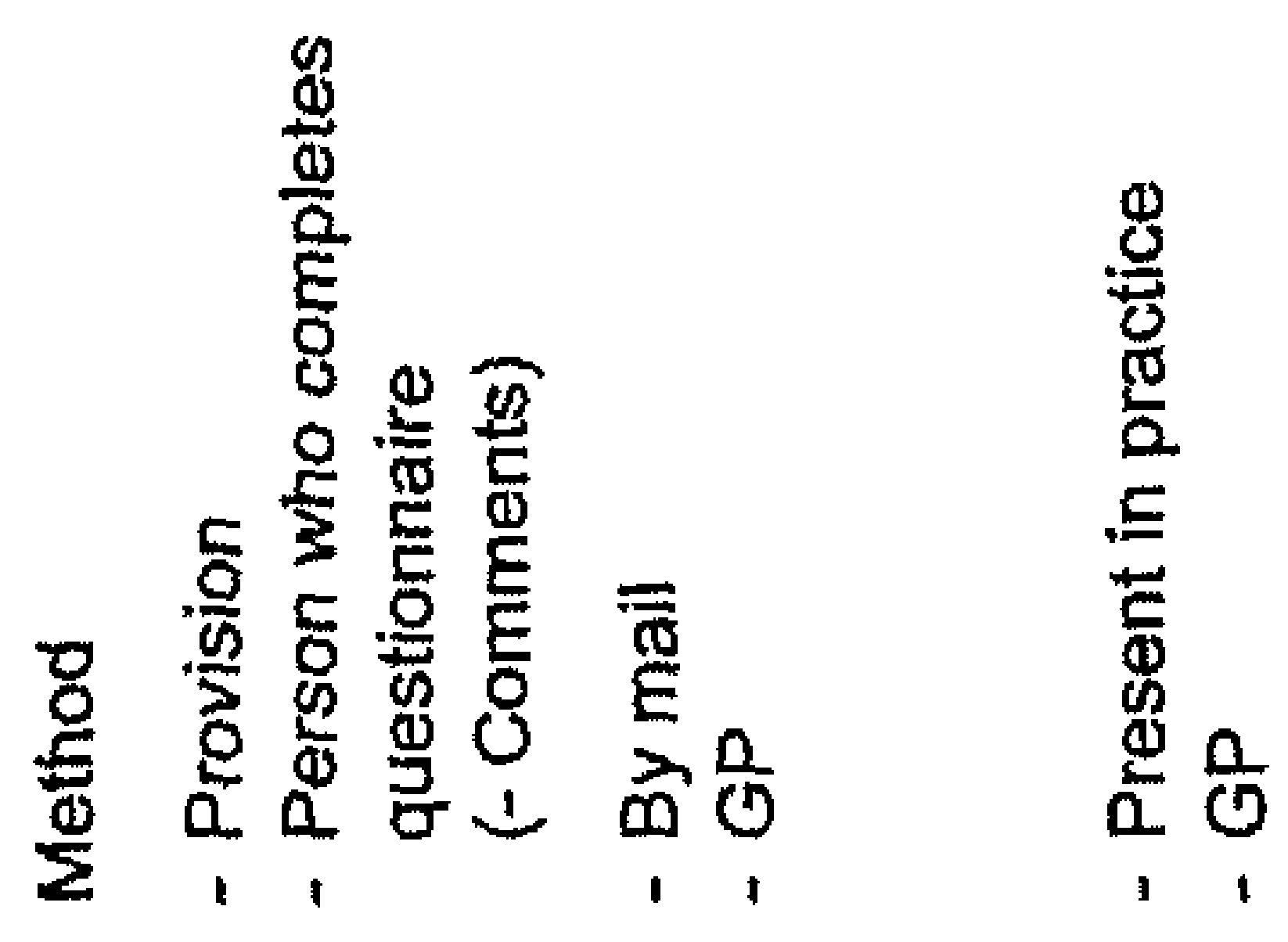

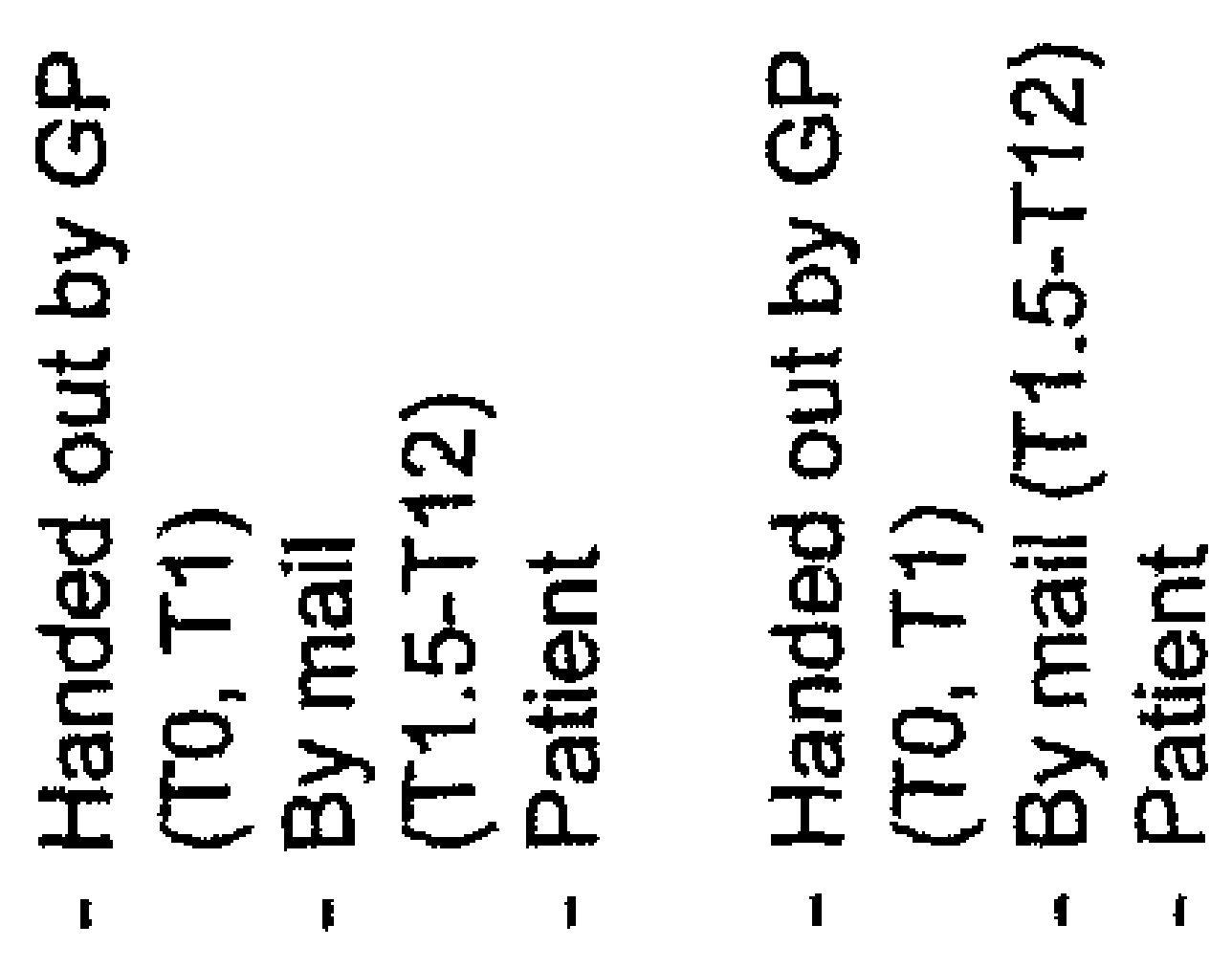

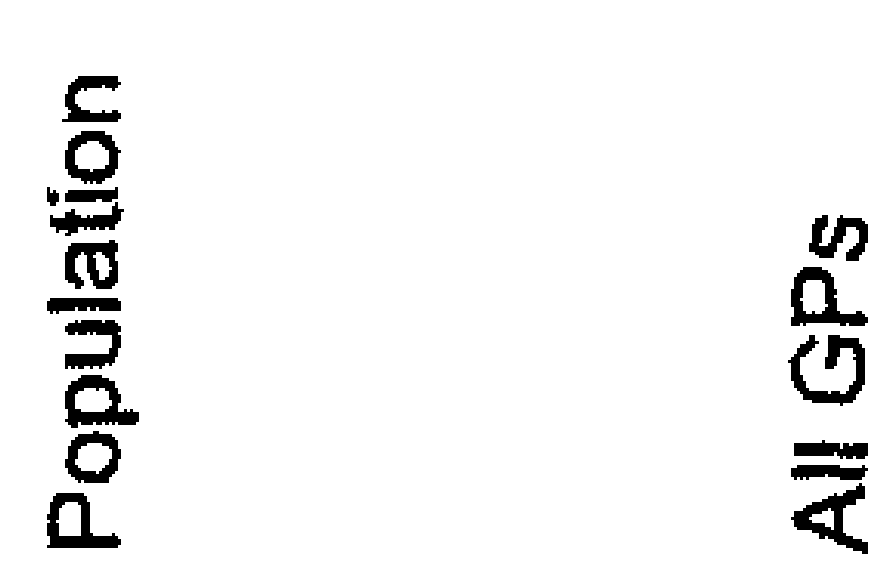

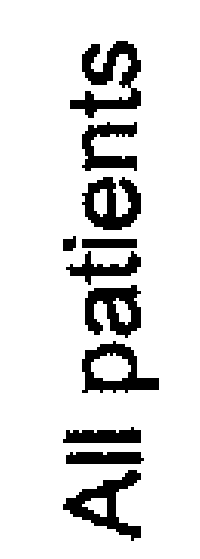

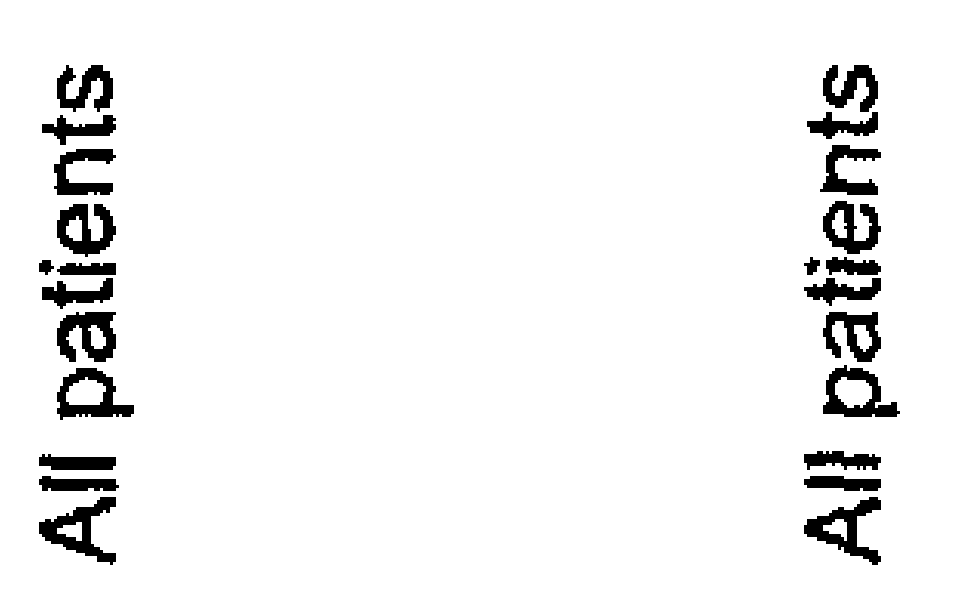

$\stackrel{乛}{F}$

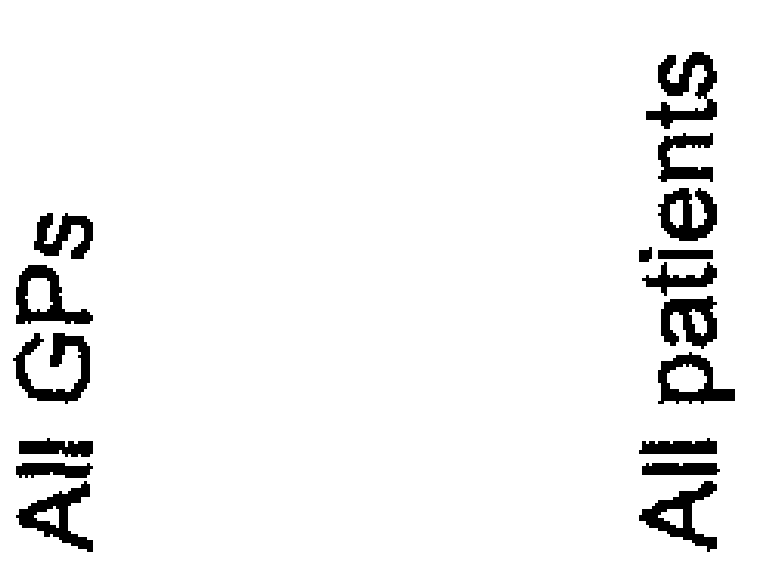

웅

总高

F

우

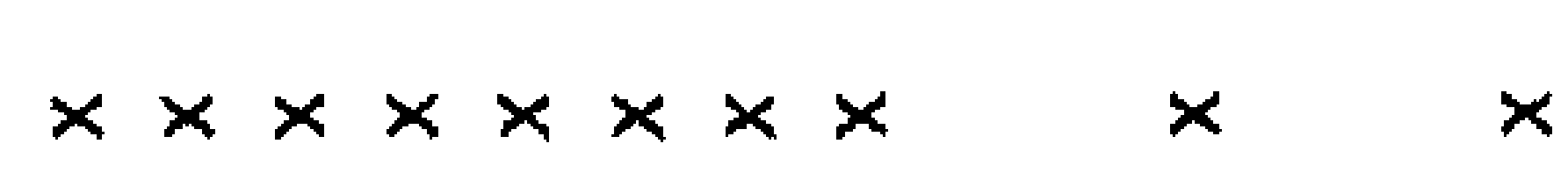

잉
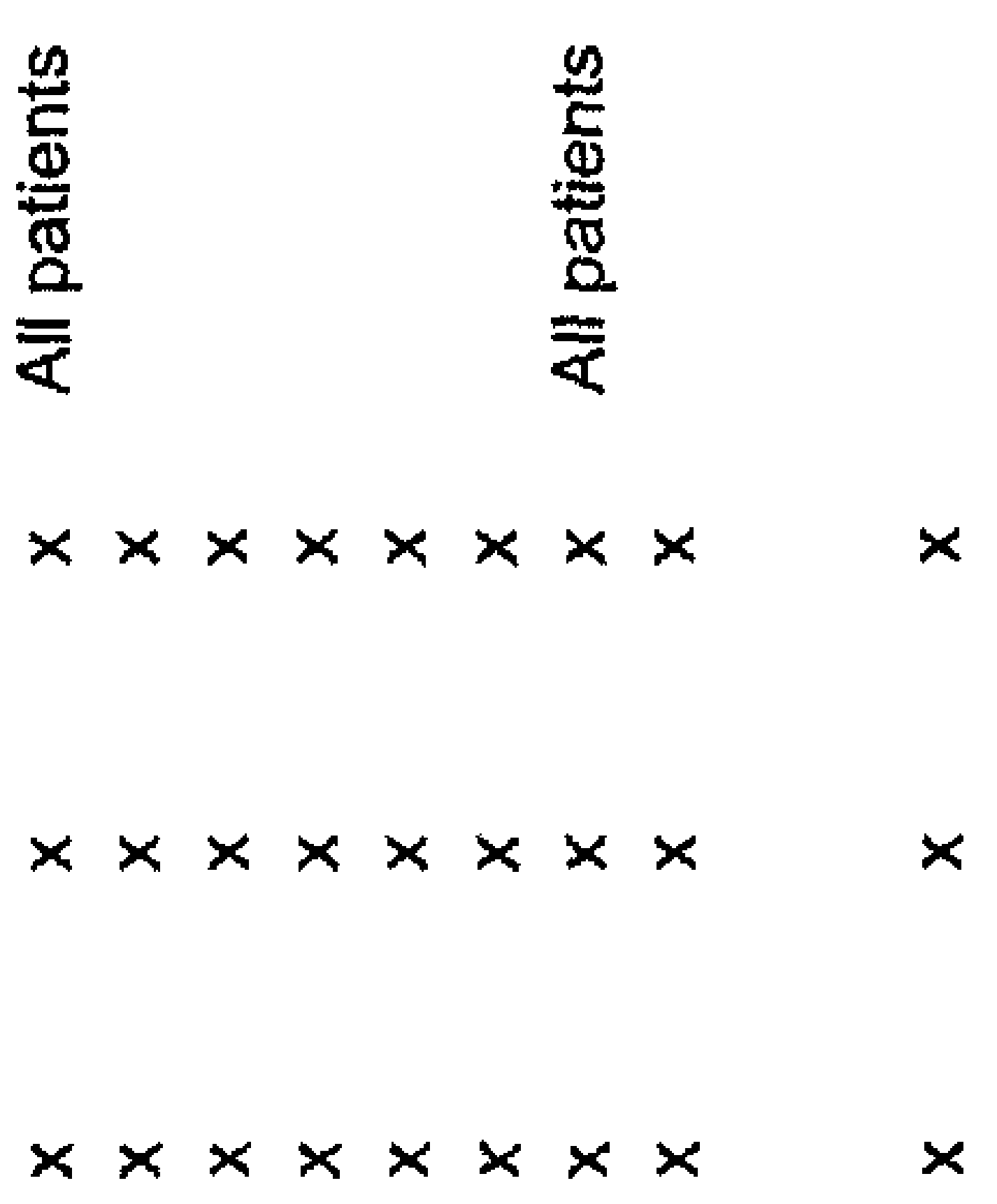

$x$

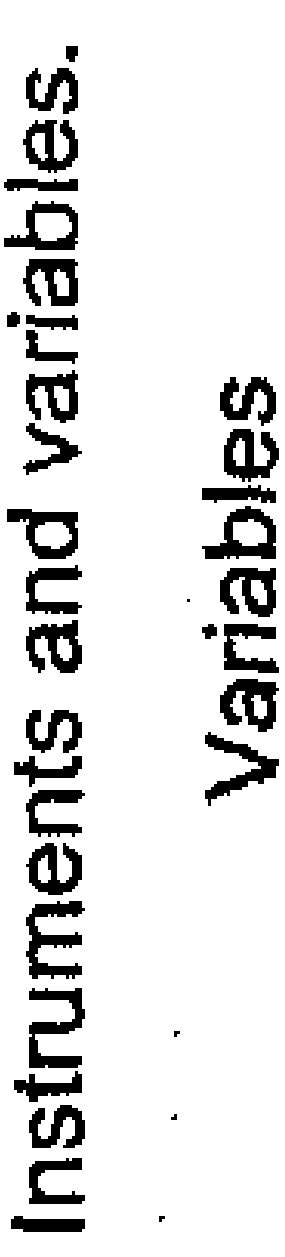

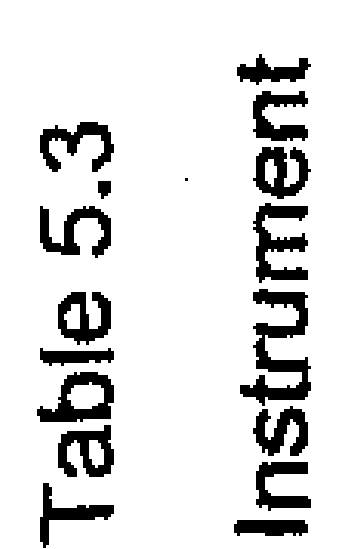

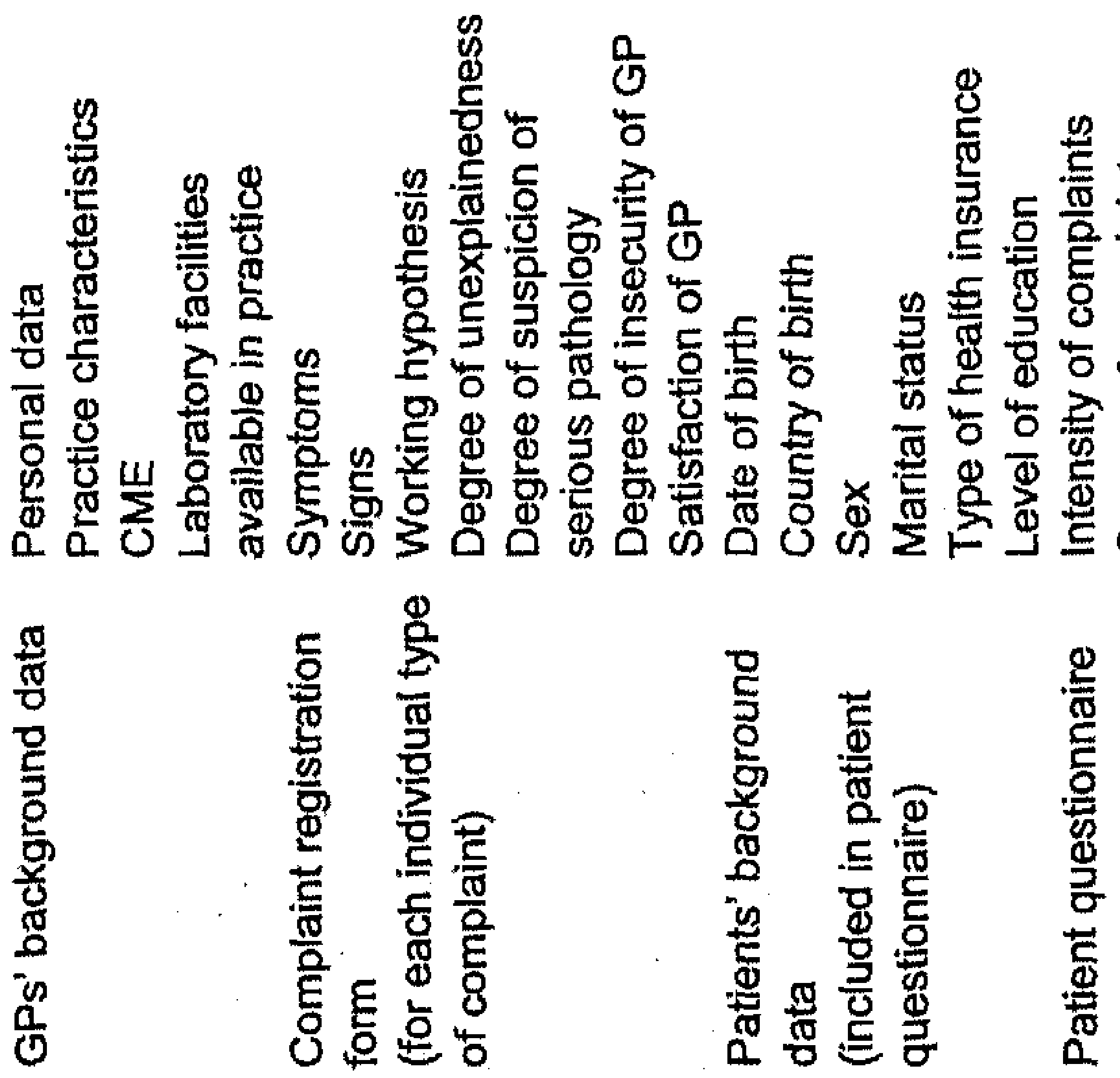


VAMPIRE randomised clinical trial protocol $\mid 93$
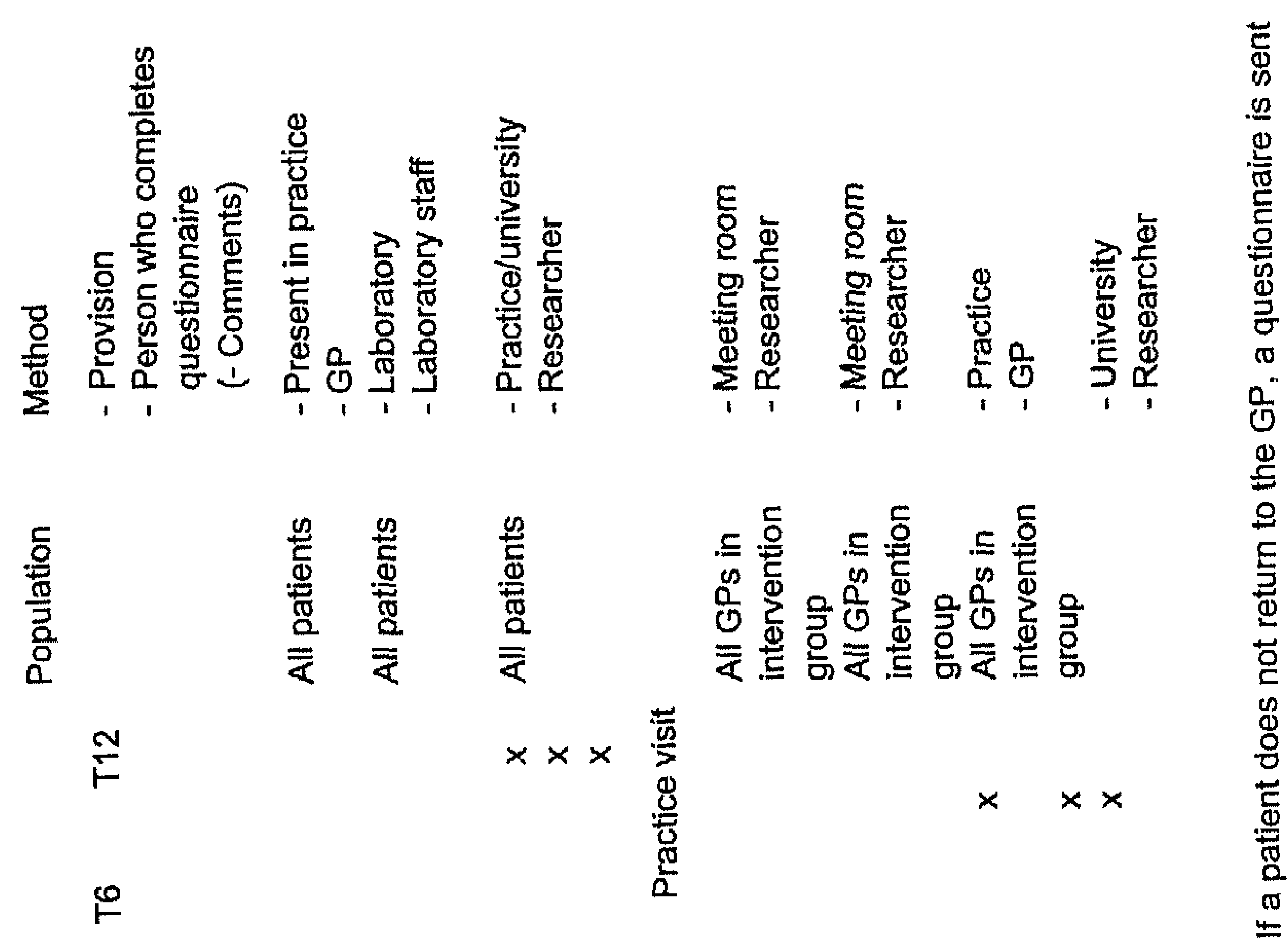

总

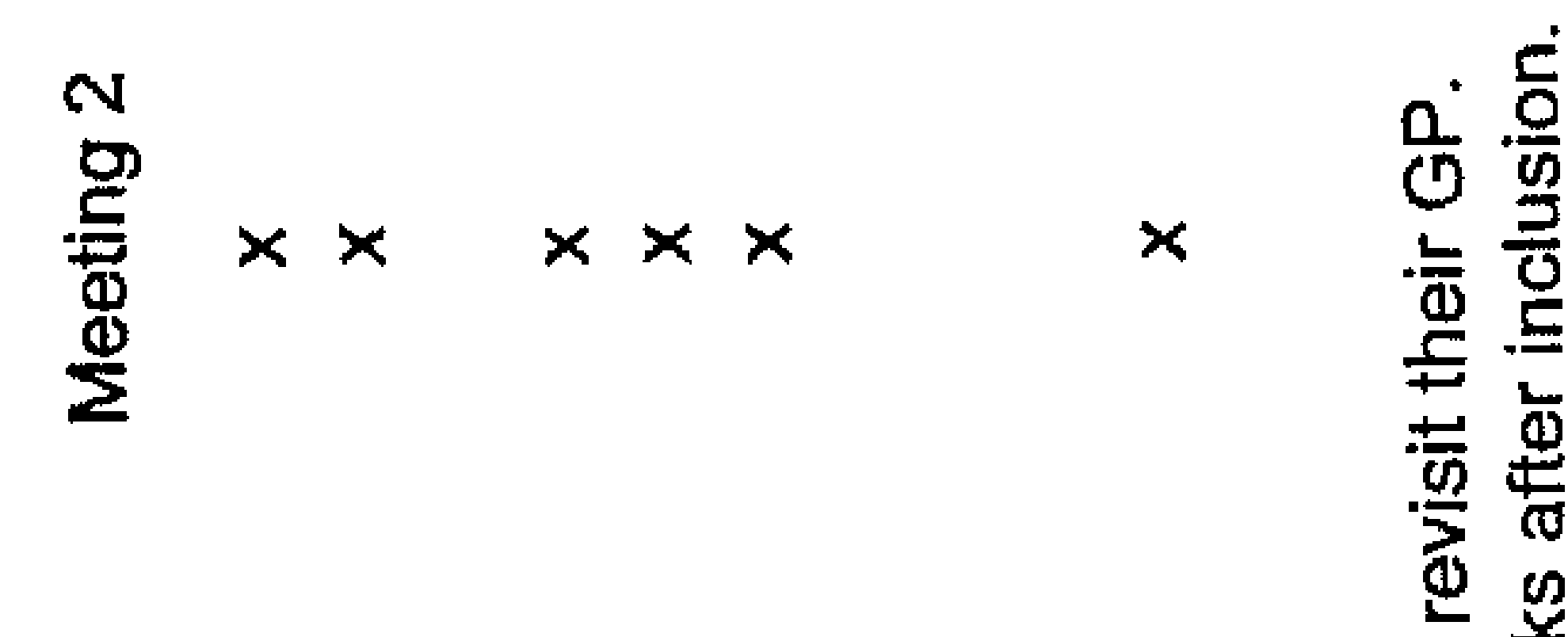

$\stackrel{*}{F} \quad{ }^{*} \times{ }^{*} \times$

曾 $\times \times \times \times \times \times \times$

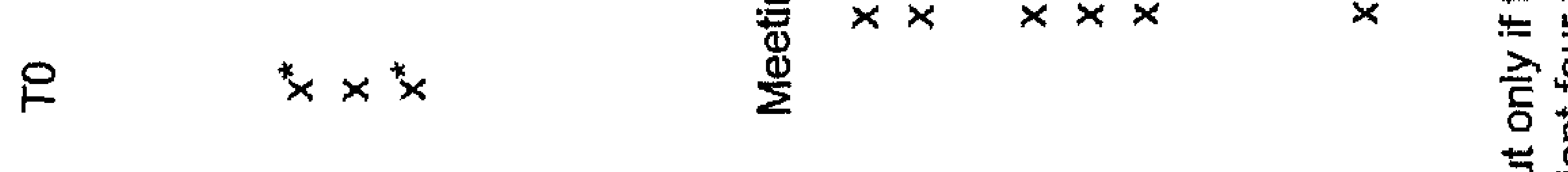

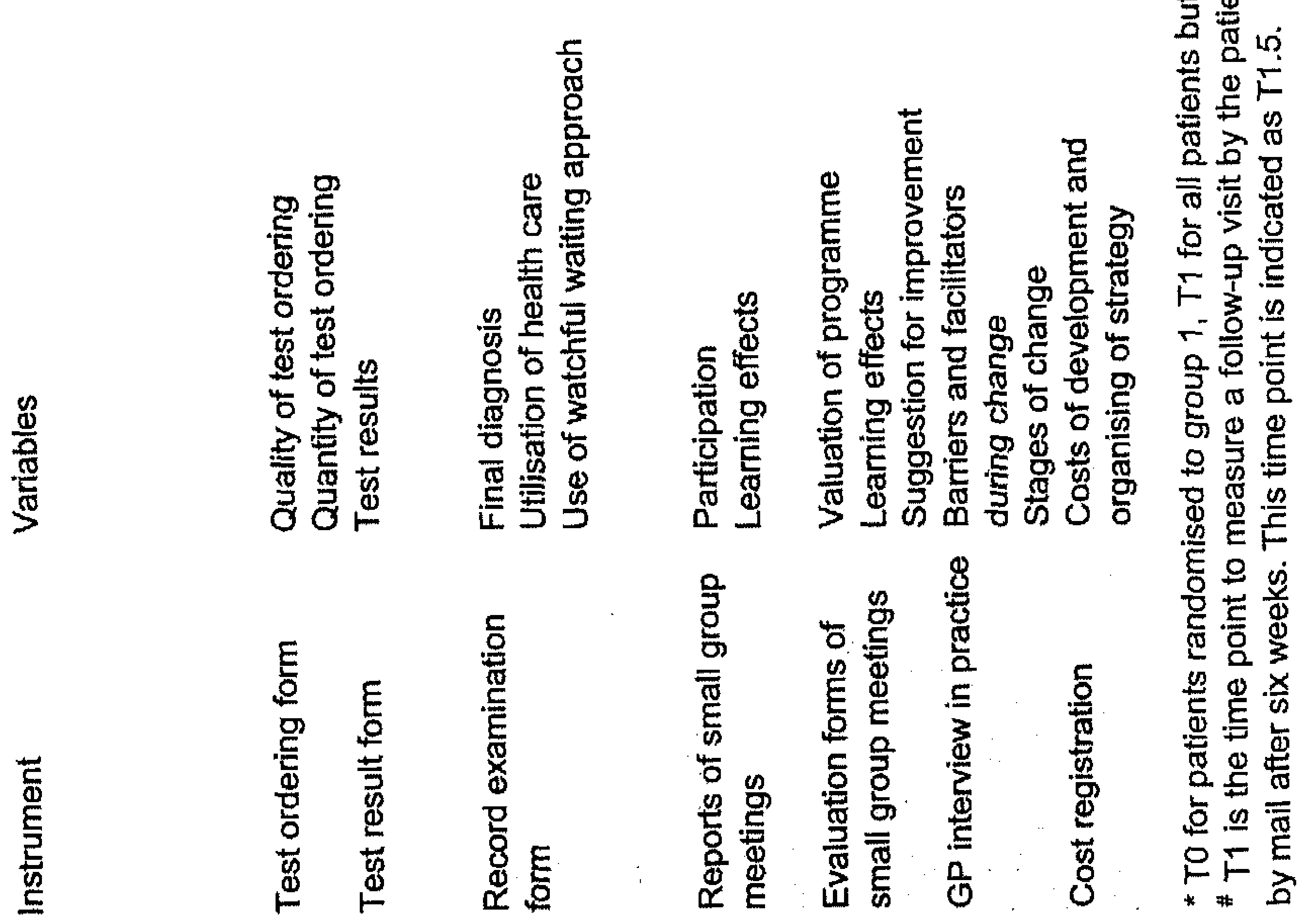




\section{Data analysis}

Primary outcome measures of the diagnostic intervention

The first primary outcome is the accuracy and added value of blood tests in detecting serious pathology (per test and in combinations relevant to general practice), related to and in addition to signs and symptoms. Serious pathology is defined as pathology requiring treatment. The second primary outcome is the effect of a 4-week postponement of test ordering on the blood test characteristics.

\section{Primary outcome measures of the quality improvement strategy}

The primary outcome of the quality improvement strategy is the quantity of tests ordered in relation to the instruction to either order blood tests immediately or to suggest a 4-week watchful waiting approach.

\section{Secondary outcome measures}

The secondary outcome measures are summarised in Table 5.4.

Table 5.4 Secondary outcome measures.

Incidence of unexplained complaints in general practice

Predictive value of GPs' working hypothesis

Duration of unexplained complaints

Effect of unexplained complaints on patients' quality of life

Effect of immediate testing or watchful waiting on patients' satisfaction with care, anxiety, medical consumption and sick leave

Effect of immediate testing or watchful waiting on GPs' satisfaction, anxiety and insecurity

Effect of quality improvement strategy on GPs' knowledge about the value of blood test ordering

in unexplained complaints, communication skills and attitudes

Barriers to and facilitators of GPs proposing a watchful waiting approach

Costs of the quality improvement strategy

\section{Types of analysis}

An intention-to-postpone analysis will be performed. Longitudinal comparisons will be made using repeated measurements techniques and multilevel analysis to correct for potential clustering of outcomes in GPs and practices. Barriers to and facilitators of change are analysed qualitatively.

\section{Non-inclusion analysis}

A non-inclusion analysis will be performed to check whether included patients are comparable to patients who are eligible but not included. 
VAMPIRE randomised clinical trial protocol $\mid 95$

\section{Discussion}

\section{Reasons for publishing this study design}

This protocol describes an RCT which combines the generation of new clinical and epidemiological evidence to underpin guidelines on test ordering in unexplained complaints with the implementation of these guidelines. To our knowledge, this is the first RCT to integrate questions on clinical epidemiology and quality of care. The first reason for us to opt for this combination is that it meets suggestions made in the literature to evaluate the value of diagnostic tests just as rigorously as is done with treatments, namely by RCTs, and to pay attention to the implementation of evidence while generating $\mathrm{it}^{27}$. Secondly, both sub-studies require large numbers of participants with the same characteristics, and combining the two increases the efficient use of available resources. Apart from the advantages of the combination, however, we also need to mention one methodological disadvantage. Ideally, the evidence on which a quality improvement strategy is based should already be available at the start of development of the strategy, as it might influence its format. In the case of this study, evidence generation on one hand and the design and execution of the strategy on the other run in parallel. Evaluation at the end of the study should clarify whether the new evidence will necessitate alterations in either the diagnostic guidelines or the quality improvement strategy.

General reasons to publish the design of a study before the analyses have begun have been discussed by Godlee and De Bruijn et al. ${ }^{28,29}$. In the case of the present study, there was an additional reason to do so. The design of the study presented here is rather complicated because, due to the nature of unexplained complaints, we had to seek methodological solutions that were not always straightforward ${ }^{22}$. By presenting the decisions made in designing this study, we are hoping to start a debate on proper methodology for research into unexplained complaints.

\section{Competing interests}

The authors declare that they have no competing interests

\section{Authors' contributions}

MB participated in working out the protocol, carries out the study in the southern region, will analyse the data of the quality improvement sub-study and wrote the first draft of the manuscript. HK participated in working out the protocol, carries out the study in the western region, will analyse the data of the diagnostic substudy and helped to draft the manuscript. TW participated in the design of the study, coordinates the quality improvement sub-study and helped to draft the 
96 Chapter 5

manuscript. RG participated in the design of the study and supervises the quality improvement sub-study. PB is the project leader of the study in the western region, supervises the diagnostic sub-study and helped to draft the manuscript. GJD is the general project supervisor, participated in the design of the study, will supervise the analyses and helped to draft the manuscript. All authors read and approved the final manuscript.

\section{Acknowledgements}

The authors would like to thank prof. dr. W.J.J. Assendelft for his contributions to the design of the research protocol. His contributions have been funded by the sources mentioned below.

\section{Funding}

The study is financed by the Dutch College of Health Care Insurances (CVZ). Supplementary financial support has been provided by the Centraal Ziekenfonds $(\mathrm{CZ})$ health insurance company, the Netherlands Organisation of Scientific Research (NWO), the 'De Drie Lichten' foundation, the Foundation for Public Health and Smoking (STIVORO) and the Netherlands Heart Foundation. None of the sources of funding influenced either the study design, or the writing of the manuscript or the decision to submit the manuscript for publication. 


\section{References}

1. Dinant GJ, van Wijk MAM, Janssens HJEM, Somford RG, de Jager CJ, Beusmans GHMI, Dijkstra RH, Wiersma Tj. NHG-standaard bloedonderzoek. Algemene principes en uitvoering in eigen beheer. [Dutch College of General Practitioners guideline 'Blood testing. General principles and use by GP']. Huisarts Wet 1994;37:202-11.

2. Kenter $E_{1}$ Okkes I, Oskam S, Lamberts $H$. Tiredness in Dutch family practice. Data on patients complaining of and/or diagnosed with 'tiredness'. Fam Pract 2003;20:434-40.

3. van der Weijden $T$, van Velsen M, Dinant GJ, van Hasselt CM, Grol RPTM. Unexplained complaints in general practice. Prevalence, patients' expectations, and professionals' testordering behavior. Med Decis Making 2003;23:226-31.

4. Kluijt I, Zaat JOM, van der Velden J, van Eijk JTM, Schellevis FG. Voor een prikje? Het gebruik van klinisch-chemische, hematologische en serologische bepalingen door de huisarts. Huisarts Wet 1991;34:67-71.

5. Zaat J. The force of habit. About the GP and his laboratory testing. [De macht der gewoonte. Over de huisarts en zijn laboratoriumonderzoek]. Amsterdam: Vrije Universiteit; 1991.

6. DeKay ML, Asch DA. Is the defensive use of diagnostic tests good for patients, or bad? Med Dec Making 1998;18:19-28.

7. Owens DK. Defensive diagnostic testing- a case of stolen utility? Med Dec Making 1998; 18:33-4.

8. Rovner DR. Laboratory testing may not glitter like gold. Med Dec Making 1998;18:32-3.

9. Vafiadis P. The dilemma of the unexpected result. Aust Fam Physician 1996;25:971-973

10. Sherwood P, Lyburn I, Brown S, Ryder S: How are abnormal results for liver function tests dealt with in primary care? Audit of yield and impact. BMJ 2001;322:276-8.

11. van der Weijden $T$, van Bokhoven MA, Dinant $G J$, van Hasselt $C M$, Grol RP. Understanding laboratory testing in diagnostic uncertainty: a qualitative study in general practice. $\mathrm{Br} J \mathrm{Gen}$ Pract 2002:52:974-80

12. Koch $H$, Meerkerk GJ, Zaat JO, Ham MF, Scholten RJ, Assendelft WJ. Accuracy of carbohydrate-deficient Transferrine in the detection of excessive alcoholconsumption: a systematic review. Alcohol 2004;39:75-85.

13. Zaat JO, van Eijk JT, Bonte HA. Laboratory test form design influences test ordering by general practitioners in the Netherlands. Medical Care 1992;30:189-98.

14. Verstappen $W H$, van der Weijden T, Sijbrandij J, Smeele I, Hermsen J, Grimshaw J, Grol RPTM. Effect of a practice-based strategy on test ordering performance of primary care physicians. A randomized trial. JAMA 2003;289:2407-12.

15. van Bokhoven MA, Kok $G$, van der Weijden $T$. Designing a quality improvement intervention: a systematic approach. Qual Saf Health Care 2003;12:215-20.

16. Brigden $\mathrm{ML}$, Heathcote JC. Problems in interpreting laboratory tests. What do unexpected results mean? Postgrad Med 2000, 107:145-146, 151-142, 155-148 passim.

17. Sanders DS, Patel D, Stephenson TJ, Ward AM, McCloskey EV, Hadjivassiliou M, Lob AJ. A primary care cross-sectional study of undiagnosed adult coeliac disease. Eur $\mathrm{J}$ Gastroenterol Hepatol 2003;15:407-13.

18. Hin $H$, Bird $G$, Fisher $P$, Mahy $N$, Jewell $D$. Coeliac disease in primary care: case finding study. BMJ 1999;318:164-7.

19. Mainous III AG, Gill JM, Pearson WS. Should We Screen for Hemochromatosis?: An Examination of Evidence of Downstream Effects on Morbidity and Mortality. Arch Intern Med 2002;162:1769-74.

20. West J, Logan RFA, Hill PG, Lloyd A, Lewis $S$, Hubbard R, Reader R, Holmes GKT, Khaw K$T$. Seroprevalence, correlates, and characteristics of undetected coeliac disease in England. Gut 2003;52:960-5.

21. Knottnerus JA, Muris JW. Assessment of the accuracy of diagnostic tests: the cross-sectional study. J Clin Epidemiol 2003;56:1118-28. 
98 Chapter 5

22. van Bokhoven MA, van der Weijden T, Dinant G-J. Challenges in the methodology of diagnostic research on patients presenting with unexplained complaints in general practice. $J$ Clin Epidemiol, in press.

23. van Bokhoven MA, Pleunis-van Empel MCH, Koch $H$, Grol RPTM, Dinant G-J, van der Weijden T. Why do patients want to have their blood tested? A qualitative study of patient expectations. BMC Fam Pract. 2006;13;7:75.

24. Hanestad BR. The MOS SF-36/RAND 36-item health survey 1.0/HSQ. In: Cross-cultural health outcome assessment. 60-65.

25. Sprangers $M A$, de Regt $E B$, Andries $F$, van Agt HM, Bijl RV, de Boer JB, Foets $M$, Hoeymans $\mathrm{N}$, Jacobs AE, Kempen Gl, Miedema HS, Tijhuis MA, de Haes HC. Which chronic conditions are associated with better or poorer quality of life? 2000;53:895-907.

26. Wilkes $L M$, Castro M, Mohan S, Sundaraj SR, Noore F. Health status of patients with chronic pain attending a pain center. 2003:4:70-76.

27. Gluud C, Gluud LL. Evidence based diagnostics. BMJ 2005, 330:724-726.

28. Godlee F. Publishing study protocols: making them visible will improve registration, reporting and recruitment. BMC News and Views 2001, 2:4.

29. Bruijn CD, de Bie R, Geraets J, Goossens M, Koke A, van den Heuvel W, van der Heijden G, Dinant GJ. Evaluation of an education and activation programme to prevent chronic shoulder complaints: design of an RCT [ISRCTN71777817]. BMC Family Practice 2005, 6:7. 


\section{Chapter 6}

Demographic characteristics and quality of life of patients with unexplained complaints: a descriptive study in general practice

H Koch, MA van Bokhoven, G ter Riet, T van der Weijden, GJ Dinant, PJE Bindels

Qual Life Res 2007:16:1483-1489

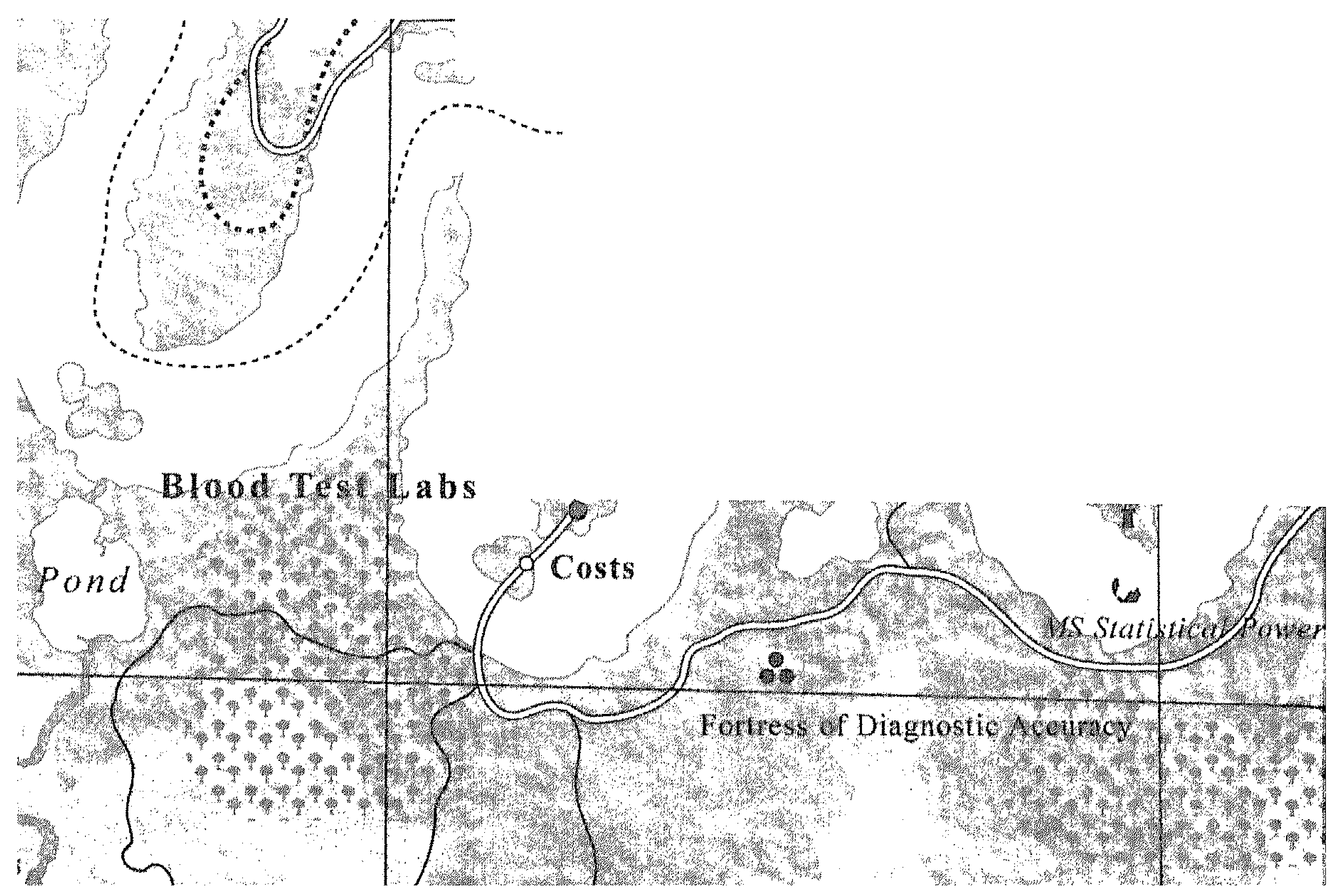


$100 \mid$ Chapter 6

\section{Abstract}

Introduction

About $13 \%$ of GPs' consultations involve unexplained complaints (UCs). These complaints can progress to chronic conditions like medically unexplained symptoms, chronic functional symptoms or somatoform disorders. Little is known about the demographic characteristics and quality of life of patients with early stage UCs. Our study objective was to describe these characteristics. Additionally we compared them with other patient groups to serve as a frame of reference.

\section{Methods}

Descriptive study in general practices. Patients with early stage UCs who had not had elaborate diagnostic investigations were included. Demographic characteristics were compared to a Dutch general practice population. Quality of life scores were measured with the RAND-36 and compared to another Dutch general practice population and to depressed patients.

Results

Data of 466 patients were available for analysis. Mean age was 44 years and $74 \%$ were females, mostly higher educated. Of the patients, $63 \%$ presented with unexplained fatigue. On average, quality of life was poor (mean RAND-36 domain scores 37-73), also in comparison with other groups.

\section{Conclusion}

General practice patients presenting with Ucs have a remarkably poor quality of life. Future research should explore how early identification of patients at risk of developing chronicity can take place. Awareness of potential poor quality of life may influence GPs' medical decision making. 
Demographic characteristics and quality of life $\mid 101$

\section{Introduction}

A patient's complaints are said to be unexplained if the general practitioner (GP) cannot decide on a specific diagnosis after adequate history taking, physical examination and careful consideration of the patient's psychosocial context ${ }^{1}$. On average, $13 \%$ of consultations involve complaints considered unexplained by Dutch $\mathrm{GPs}^{2}$. These unexplained complaints often concern fatigue, abdominal and musculoskeletal complaints.

It is often assumed that unexplained complaints are mild and self-limiting, because patients do often not revisit their GP for them after a first consultation $^{3,4}$. However, an unexplained complaint can be a first sign of somatic or psychosocial pathology or a precursor of more chronic unexplained complaints such as chronic medically unexplained symptoms (MUS), chronic functional symptoms or somatoform disorders ${ }^{5}$.

Patients with chronic unexplained conditions often have high levels of medication and other healthcare use and frequently show significant psychological distress ${ }^{6}$. Patients with multiple medically unexplained symptoms (MMUS) have impaired quality of life ${ }^{7}$. Furthermore, patients often do not feel taken seriously, do not feel helped and feel treated as malingerers. They, therefore, tend to lose trust in their $\mathrm{GPs}^{8}$. In brief, the long-term consequences of many unexplained complaints are unfavourable.

GPs too consider unexplained complaints problematic. One study found that in consultations with such patients GPs feel frustrated and helpless though devoted to help ${ }^{9}$.

Research on unexplained complaints is increasing. So far, most research has focused on patients with chronic consequences of unexplained complaints. This research varies from discussions on nomenclature and taxonomy ${ }^{10-12}$, to research on the characterization of these patient groups $^{7,13}$ and possible treatment options ${ }^{14-16}$. Little is known about patients with unexplained complaints in their early stages. We performed this study to describe the demographic characteristics and quality of life of patients with early stage unexplained complaints. To provide some frame of reference, we compared these descriptive measures for the unexplained complaints to those of an unselected group of patients visiting their GP, and a group of depressed patients. For practitioners, better delineation, in terms of quality of life, of a group of patients that frequently seeks their help may sensitise them to consider more structured monitoring in order to achieve a firmer diagnosis be it somatic, psychological, or psychosocial. 


\section{Methods}

\section{GPs and patients}

GPs were recruited from the southern and the western parts of the Netherlands. GPs were given the Dutch College of General Practitioners' definition of unexplained complaints: those complaints that remain of unclear origin for the GP after adequate history taking, physical examination and careful consideration of the patient's psychosocial context $t^{1}$. This definition supposes that complaints are labelled "unexplained" early on in the clinical episode before elaborate investigations were performed.

Between February 2002 and December 2003, participating GPs included adult patients, presenting with a complaint that the GP designated as "unexplained" at the end of the first consultation. Patients who had presented with the same complaint in the previous six months were not included. Patients were eligible if they presented with fatigue, abdominal complaints, musculoskeletal complaints, weight changes or itch as their main complaint.

Individual GPs decided whether a complaint was "unexplained". There was no standardization of this process other than that implied by the Dutch College of General Practitioners' definition. GPs invited patients to participate in the study at the end of the consultation.

\section{Informed consent procedure and medical ethics committees}

All participating patients gave written informed consent after having read information provided by the GP directly after the consultation. The medical ethics committees of the University of Amsterdam and Maastricht University approved the study protocol.

\section{Data collection: study population}

The data for this study were collected as part of baseline measurements for a randomised diagnostic trial on unexplained complaints in general practice ${ }^{17}$. After the entry consultation, patients filled out a questionnaire on demographic characteristics. The RAND 36-item Health Survey (RAND-36) was used to measure generic health-related quality of life. The RAND-36 ${ }^{18}$ is a Dutch version of the Medical Outcome Study 36-item Short Form Health Survey $(\mathrm{SF}-36)^{19}$ and is composed of 36 questions and standardized response choices, organized into eight multi-item scales (domains). These eight domains are: physical functioning (PF), role limitations due to physical health problems (RP), social functioning (SF), general mental health $(\mathrm{MH})$, role limitations due to emotional problems (RE), vitality (VT), bodily pain (BP) and general health 
Demographic characteristics and quality of life $\mid 103$

perception (GH). Raw RAND-36 scores on the eight domains are linearly converted to $0-100$ scales with higher scores indicating better quality of life.

\section{Data collection: reference populations}

\section{Reference population for comparison of demographic characteristics}

The demographic characteristics of a Dutch general practice population were taken from the second Dutch National Survey of General Practice, which is a large representative population-based survey that takes place every 10 years. Methods of this study have been published elsewhere ${ }^{20}$. Briefly, this national survey contains data about health and healthcare-related behaviour of 375,899 persons, registered in 104 practices with 195 GPs in 2001.

\section{Reference populations for comparison of quality of life}

The results section of this manuscript shows that the quality of life of patients with early stage unexplained complaints is poor. Our initial objective was purely descriptive. However, when such low quality of life figures were found, we felt the need to compare these to other patient groups. First, we wondered whether maybe all patients consulting their GP would have such low quality of life figures and therefore compared the unexplained complaints group with a Dutch general practice population. We also thought that maybe our patient population included many depressed patients which could explain the poor quality of life and therefore also compared our quality of life figures with those of a population of depressed patients.

Figures of the Dutch general practice population came from a study on functional status, health problems, age and co-morbidity in primary care patients ${ }^{21}$. In this study 60 GPs from 43 general practices handed out a written questionnaire to 100 patients of 18 years and older, consecutively visiting their practice. In total 4,024 patients responded.

Figures of the depressed patients came from the Netherlands Mental Health Survey and Incidence Study (NEMESIS). This NEMESIS survey, was based on a random sample drawn from the Dutch general adult population aged 18-64 $(n=7,076)$ of whom 204 had been diagnosed with a major depression within the past month ${ }^{22}$.

\section{Statistical analysis}

First, we compared the demographic characteristics of the five unexplained complaint categories to each other. Those of the total UC study population were compared to those of a Dutch general practice population. Differences were tested using the Fisher's exact test. 
$104 \mid$ Chapter 6

Second, mean domain scores on the RAND-36 were compared for each of the five unexplained complaint groups using linear regression with the "fatigue" complaint group as the reference category. We calculated robust variance estimates (Huber-White sandwich estimator) ${ }^{23}$ to allow for potential dependence of quality of life scores within a single GP.

Lastly, we compared mean domain scores of the total UC study population to those of a Dutch general practice population sample and to a random sample of depressed patients. Differences were statistically tested with t-tests in which equal variances were not assumed. Analyses were performed using STATA, version 9.2.

\section{Results}

\section{General characteristics of the study group}

Of the 91 GPs who intended to participate, 18 dropped out before including any patients. They predominantly reported lack of time as the reason for drop out. Ten GPs did not include any patients during the inclusion period, although they did not formally drop out. Thus, 63 GPs (69\%) included 513 patients with unexplained complaints (range: 1-36 patients per GP). Questionnaires from $466(91 \%)$ patients were available for analysis. Forty-seven patients stopped their participation to the study or did not fill out this particular questionnaire.

\section{Demographic characteristics of the study group}

The demographic characteristics are summarized in Table 5.1, for the total UC study population, per complaint group and for the Dutch general practice population. The mean age of the total UC study population was 44 years (interquartile range 31-55) and $74 \%$ were women. Most patients had completed secondary or higher level education $(91 \%)$ and were married or living together with a partner $(71.5 \%)$.

The main reason for encounter was fatigue $(63.3 \%)$ and only few patients with weight changes or itch were included. In all further analyses, these latter two groups were combined into an "other complaints" group.

Patients with musculoskeletal complaints were significantly older and less educated than patients with fatigue or abdominal complaints $(P<0.05)$.

Compared to patients from the Dutch general practice population (second Dutch National Survey of General Practice), unexplained complaint patients were more likely to be women ( $74 \%$ vs. $51 \%$ ), older ( $46 \%$ vs. $33 \%$ in the age group $40-64)$ and more highly educated (91\% vs. $65 \%$ secondary or higher level education). These differences were statistically significant $(P<0.05)$. 
Demographic characteristics and quality of life $\mid 105$

Table 6.1 Demographic characteristics of the total UC study population, per complaint group and of a Dutch general practice population.

\begin{tabular}{|c|c|c|c|c|c|c|}
\hline Demographic characteristic & $\begin{array}{l}\text { Total UC study } \\
\text { population } \\
\%(n=466)\end{array}$ & $\%(n=295)$ & $\begin{array}{l}\text { Abdominal } \\
\text { complaints } \\
\%(n=60)\end{array}$ & $\begin{array}{l}\text { Musculoskeletal } \\
\text { complaints } \\
\%(n=69)\end{array}$ & $\begin{array}{l}\text { Other } \\
\text { complaint } \\
\text { groups } \\
\%(n=42)\end{array}$ & $\begin{array}{c}\text { Dutch GP } \\
\text { population } \\
\%(n=3,85,461)\end{array}$ \\
\hline \multicolumn{7}{|l|}{ Sex } \\
\hline Male & 26.4 & 26.1 & 25 & 24.6 & 33.3 & 49.5 \\
\hline Female & $73.6^{\mathrm{a}}$ & 73.9 & 75 & 75.4 & 66.7 & 50.5 \\
\hline \multicolumn{7}{|l|}{ Age } \\
\hline Mean (years) & 44.2 & 41.8 & 42.3 & $52.2^{\mathrm{b}}$ & 50.3 & Unknown \\
\hline $0-19$ & 4.9 & 6.1 & 6.7 & 1.1 & 0 & 23.4 \\
\hline $20-39$ & 37.1 & 42 & 45 & 13 & 30.9 & 30.4 \\
\hline $40-64$ & $45.9^{\mathrm{a}}$ & 41.7 & 40 & 66.7 & 50 & 33 \\
\hline $65+$ & 12 & 10.2 & 8.3 & 18.8 & 19.1 & 13.2 \\
\hline \multicolumn{7}{|l|}{ Educational level } \\
\hline None & 1 & 0 & 0 & $4.3^{b}$ & 2.4 & 16 \\
\hline Elementary & 9 & 7.5 & 3.3 & $17.4^{\mathrm{b}}$ & 14.3 & 18.9 \\
\hline Secondary & $68.9^{\mathrm{a}}$ & 68.1 & 80 & $59.5^{b}$ & 64.3 & 48.1 \\
\hline Higher & $22.1^{\mathrm{a}}$ & 24.4 & 16.7 & 18.8 & 19 & 17 \\
\hline \multicolumn{7}{|l|}{ Marital state } \\
\hline Single & 28.5 & 29.8 & 20 & 30.4 & 28.6 & Unknown \\
\hline Married/cohabiting & 71.5 & 70.2 & 80 & 69.5 & 71.4 & Unknown \\
\hline \multicolumn{7}{|l|}{ Insurance Type } \\
\hline Public & 65.2 & 65.8 & 68.3 & 69.6 & 50 & 67.4 \\
\hline Private & 34.8 & 34.2 & 31.7 & 30.4 & 50 & 32.6 \\
\hline \multicolumn{7}{|l|}{ Nationality } \\
\hline Dutch & 95.3 & 96.3 & 96.7 & 91.3 & 93 & 86.2 \\
\hline Not Dutch & 4.7 & 3.7 & 3.3 & 8.7 & 7 & 13.8 \\
\hline \multicolumn{7}{|l|}{ Region of the Netherlands } \\
\hline West & 56.4 & 57.6 & 46.7 & 62.3 & 52.4 & Unknown \\
\hline South & 43.6 & 42.4 & 53.3 & 37.7 & 47.6 & Unknown \\
\hline
\end{tabular}

Quality of life of the total UC study population and per unexplained complaint group

The overall quality of life for the total UC study population was poor (Table 5.2). All domains showed a mean score of less than 70 (on a scale from 0 to 100), except Physical Functioning (mean 73.4). The lowest score was in the Role Functioning Physical domain (mean 37.2). Also the Vitality domain scored low (mean 40.5) both in the total UC study population and in the separate complaint groups.

Except for the Physical Functioning and Bodily Pain scales, patients with unexplained fatigue significantly scored the worst $(P<0.05)$ in every domain, especially on the Role Functioning Physical domain (mean 31.5). Patients with musculoskeletal complaints showed the significantly lowest score on Physical Functioning (mean 62.2) and Bodily Pain (mean 55.5) $(P<0.05)$. 
$106 \mid$ Chapter 6
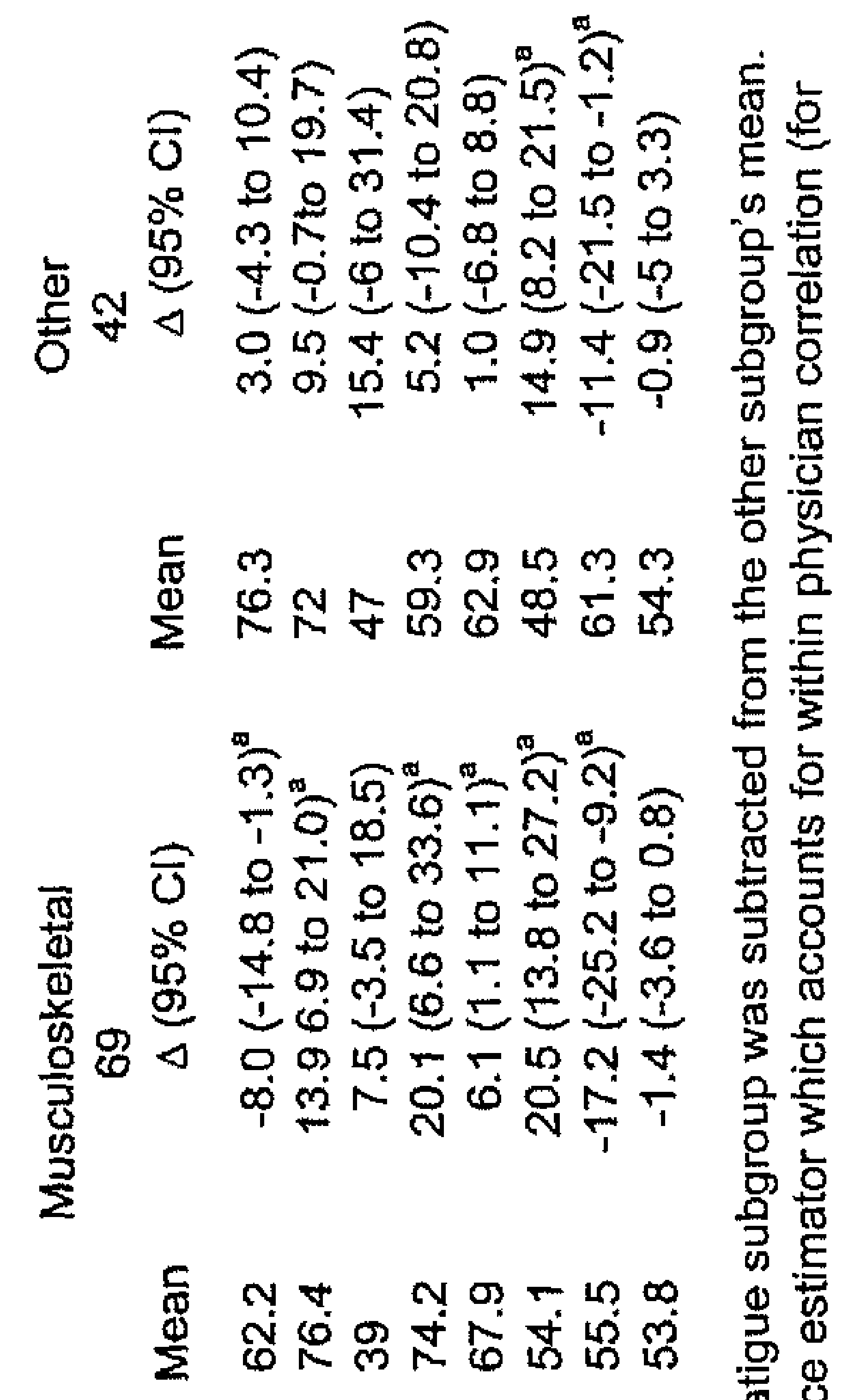

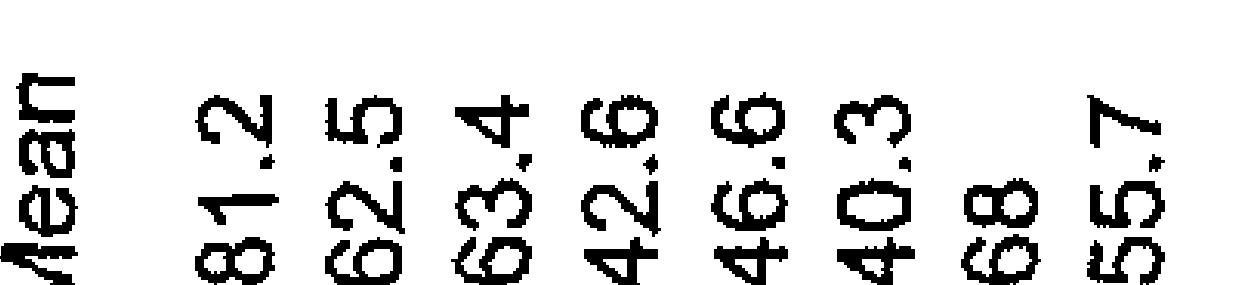

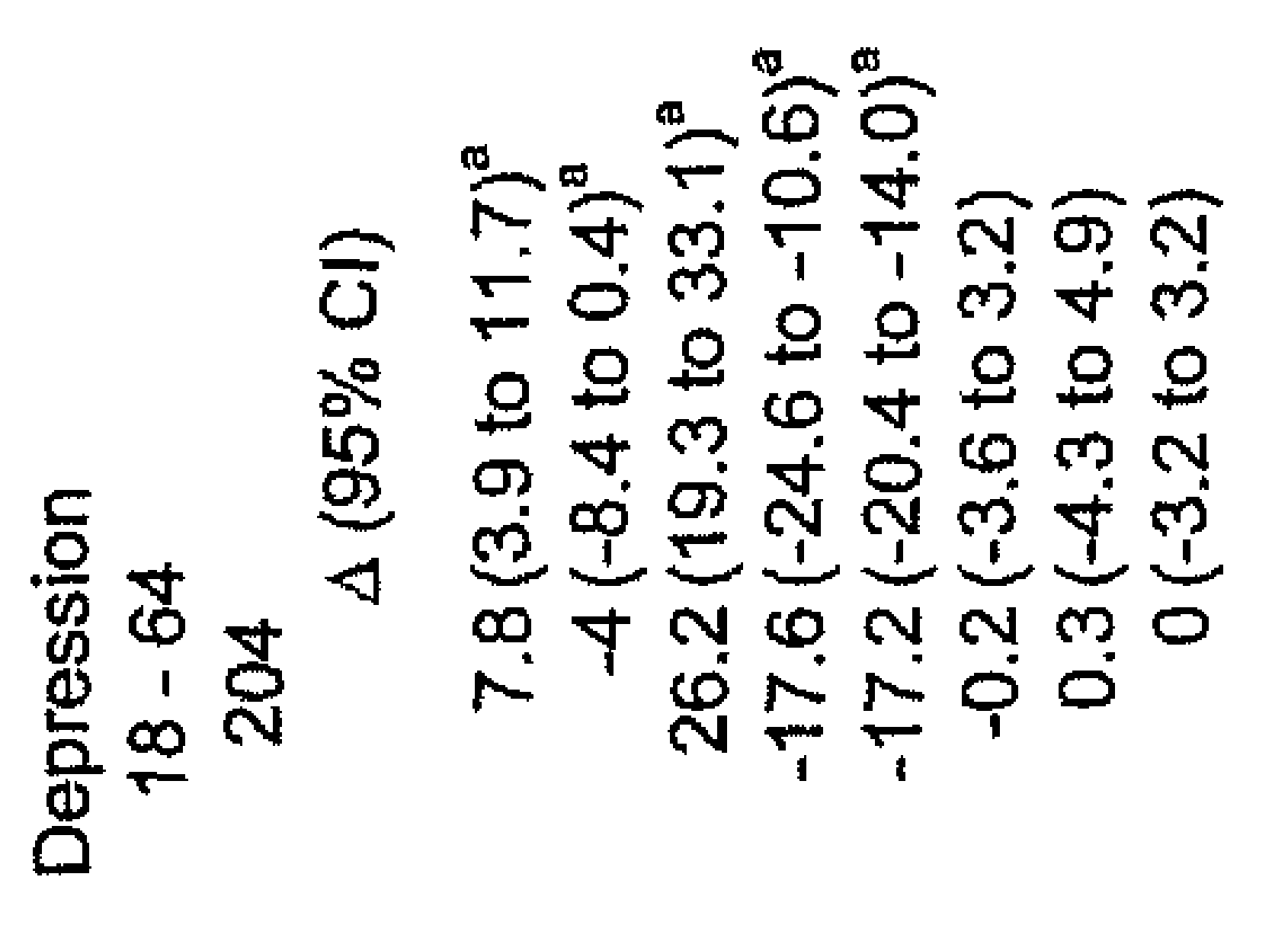

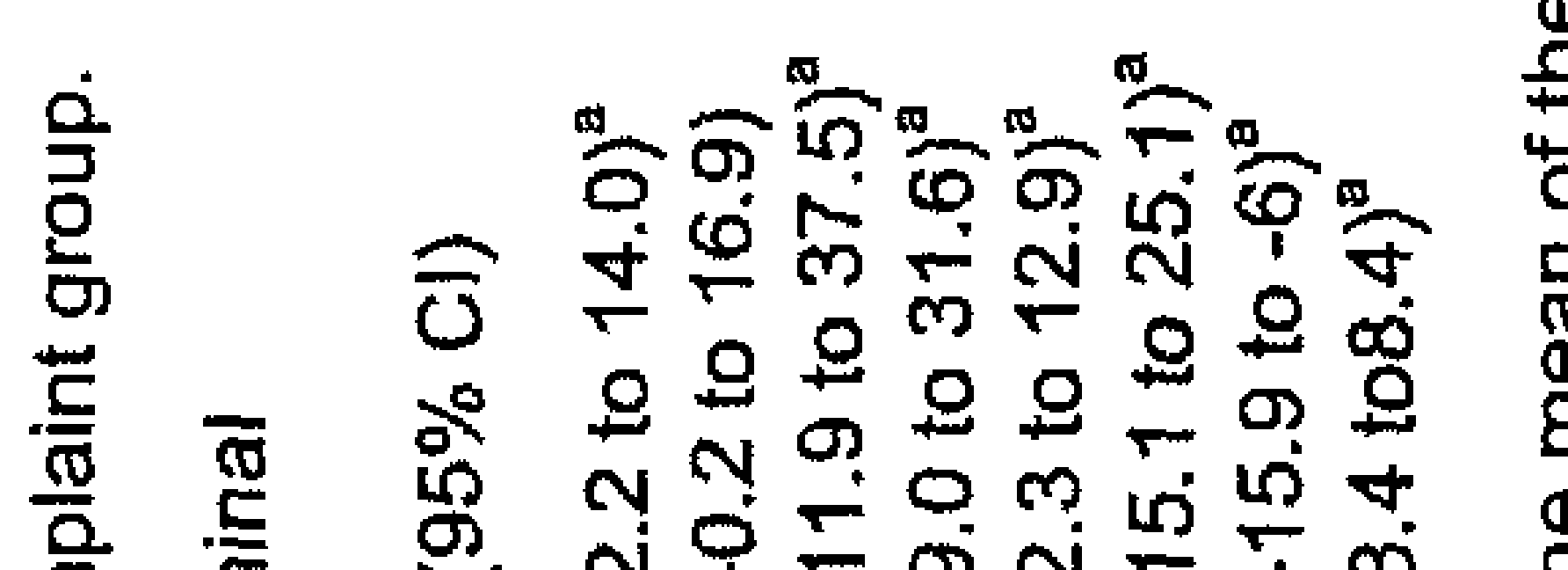

Сิ

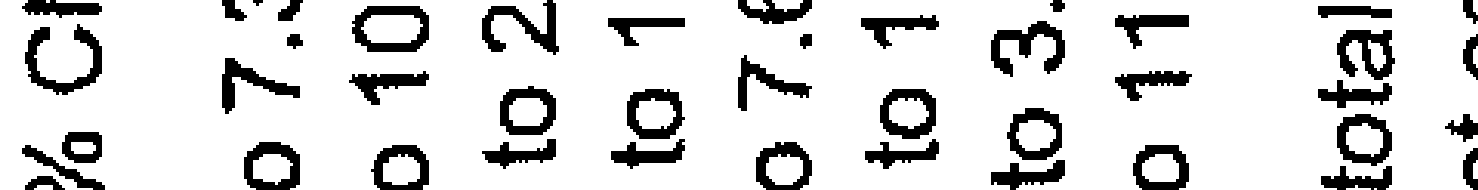

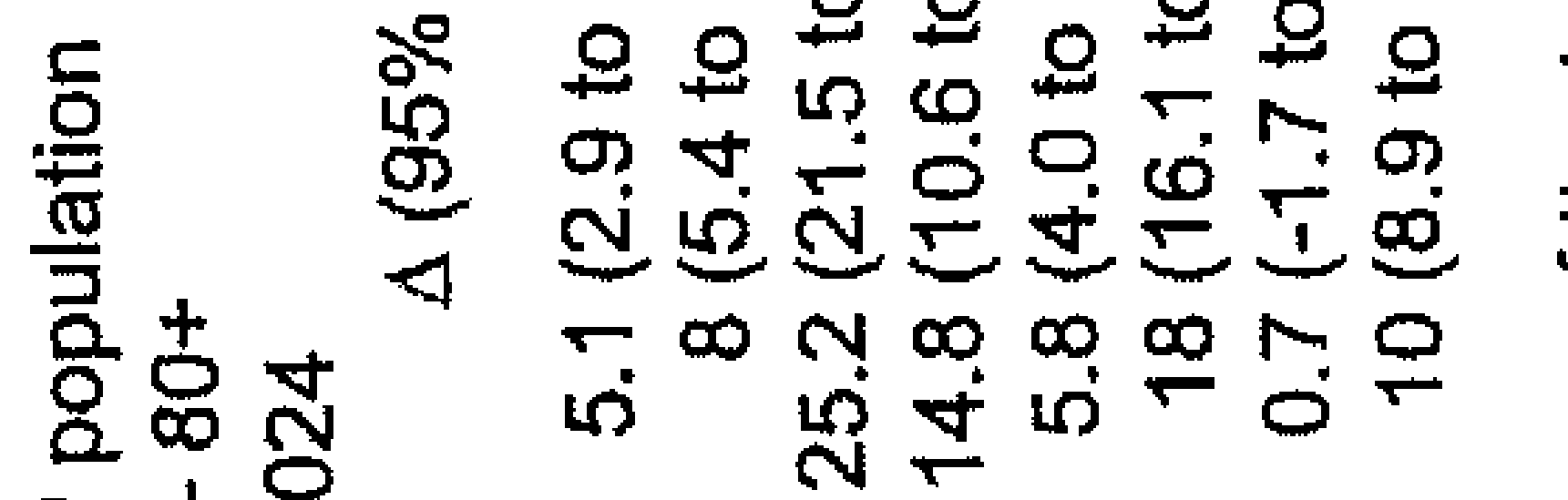
品

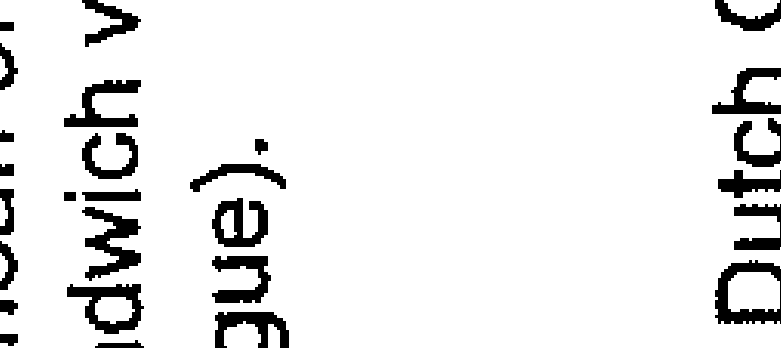
品

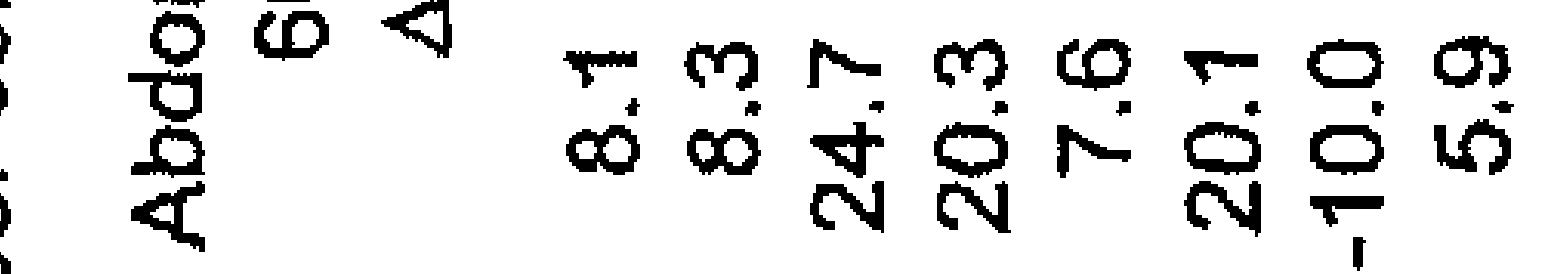

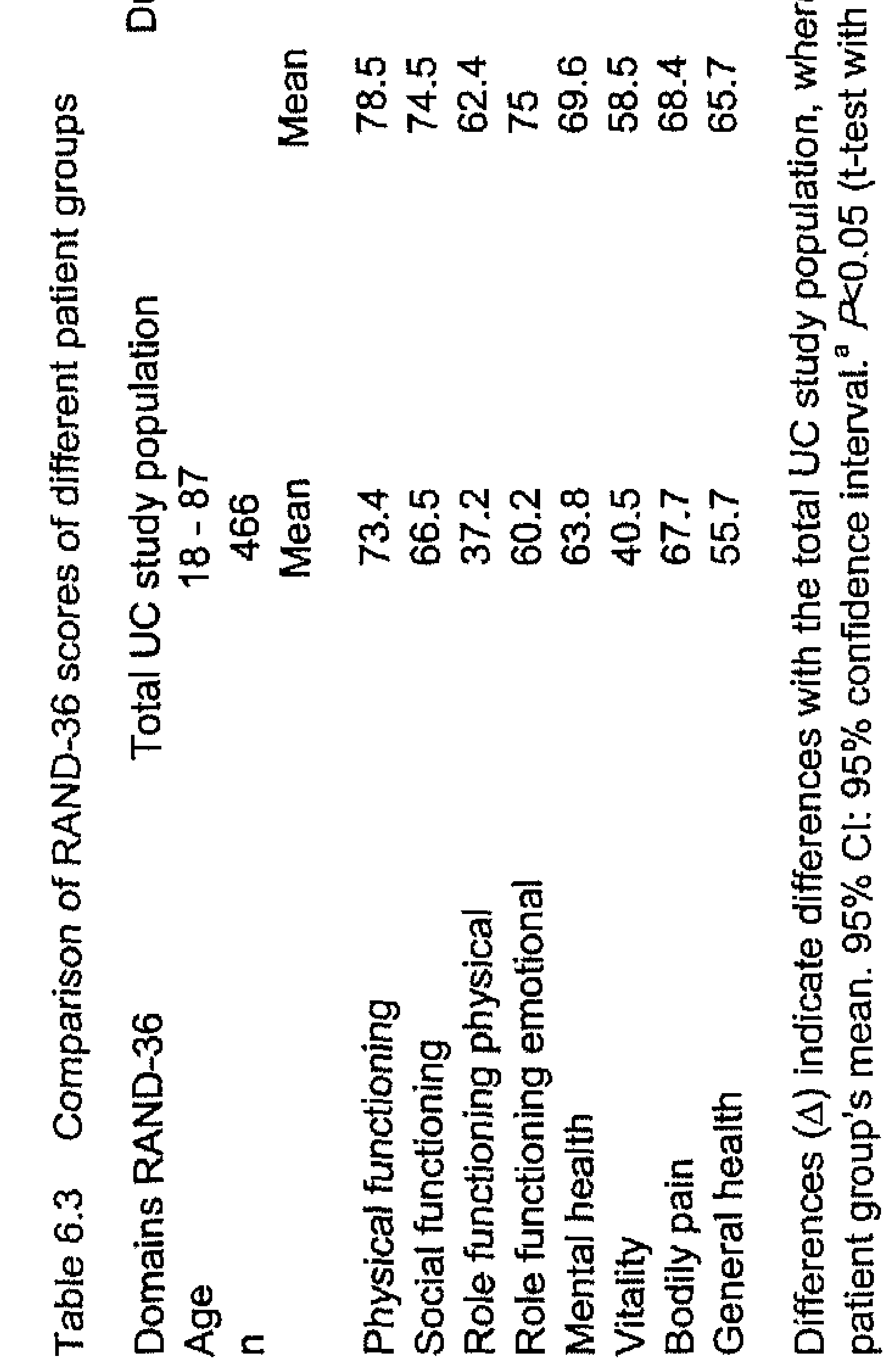




\section{Comparison of quality of life with other patient groups}

Table 6.3 shows that the total UC study population scored lower on all domains than the Dutch general practice population. These differences were statistically significant $(P<0.05)$ for all domains except Bodily Pain.

Patients from the depression group scored significantly lower on the Role Functioning Emotional and Mental Health domains. On all the other domains the total UC study population scored equally high or significantly lower (Physical Functioning and Role Functioning Physical, $P<0.05$ ) than patients from the depression group. In other words, unexplained complaint patients scored lowest on predominantly physically oriented domains, whereas depressed patients scored lowest on predominantly mentally/emotionally oriented domains.

\section{Discussion}

Our findings indicate that patients with early stage unexplained complaints are mainly women in their forties, with secondary or higher education levels and with an overall remarkably poor quality of life. Their quality of life in all but one domain of the RAND-36 is significantly worse than that of patients from a general practice population, even taking into account that such a population also includes (around $13 \%$ of) unexplained complaint patients. Patients with unexplained complaints predominantly score badly on physically oriented domains, compared to depressed patients, who predominantly score badly on mental/emotional oriented domains. For the remaining domains they score on a comparably low level. Therefore, practitioners may consider to pay attention to quality of life aspects of patients with early stage unexplained complaints, even though this may not always lead to a firmer diagnosis or instant improvement in treatment options for most patients. A more intense monitoring of these patients could, however, be advised.

The total UC study population scored very low on the Vitality domain of the RAND-36 (mean 40.5). This domain consists of questions regarding spirit and energy. The Vitality domain of the SF/RAND-36 is known to be correlated with subjective feelings of fatigue ${ }^{24}$ and we therefore interpret this finding as a logical consequence of the high prevalence of patients with fatigue in the study population. Patients with unexplained complaints do not seem to have predominantly psychosocial problems. The domains Social Functioning and Mental Health were not the worst scoring domains in the study population (mean 66.5 and 63.8 respectively). The Role Functioning Physical domain scored much lower (mean 37.2), suggesting that patients with unexplained complaints feel that their physical complaints hinder them in their daily 
$108 \mid$ Chapter 6

functioning. Of the five categories of unexplained complaints, patients with unexplained fatigue have the poorest quality of life.

A first potential limitation of our study can be that different definitions and conceptualizations of unexplained complaints limit the generalizability of our findings. In our study, unexplained complaints were labelled "unexplained" by the GPs in the first consultation after onset, before more elaborate diagnostics. This is in contrast to medically unexplained symptoms (MUS), which refer to symptoms that have been ruled out to have an explainable cause (diagnosis by exclusion). Our concept of early stage unexplained complaints does not allow one to draw firm inferences as to whether the lower quality of life levels can be attributed to the unexplained complaints or should be attributed to underlying, though not yet diagnosed conditions, or concurrent co-morbidity.

Second, we cannot fully exclude the possibility that some degree of selection bias is present. Participating GPs may have selectively included older patients or those with poorer quality of life. However, in a non-inclusion study in the participating general practices, we searched the electronic medical files by means of text words for eligible but not included patients with unexplained complaints. This non-inclusion study did not show major sex and age differences between included and not-included patients. However, differences may exist on other characteristics.

A third limitation of our study is that no specific depression or anxiety questionnaire was used. At the start of the study, such a poor quality of life was not anticipated and, therefore, only a more general questionnaire was considered sufficient. The RAND-36 mentally/emotionally oriented domain figures and the differences we found when comparing the quality of life profile of unexplained complaint patients with depressed patients however, are not pointing towards the presence of depression or anxiety. Furthermore, the GPS did not consider the included patients to be depressed or suffering from an anxiety disorder, otherwise they would not have labelled the patient as having unexplained complaints by definition. It is not impossible however, that depression or anxiety disorders might play a role in the poor quality of life of patients with unexplained complaints. Maybe these diagnoses are established only by GPs over time, and do not become clear in (one of) the first consultations.

Finally, the patient groups used for comparison of quality of life are perhaps not totally comparable to our study population. For example, there are older patients included in our study population than in the depressed patient groups. Since age has its influence on quality of life this can have influenced the contrast. Also, a depression is a treatable condition, whereas early stage unexplained complaints are not treated yet. The better quality of life in this patient group on some domains can therefore be a treatment effect. We did, 
however, not intend to study a fully comparable contrast in this sense beforehand, it was a result driven comparison.

Although much research has been performed in patients with more chronic consequences of unexplained complaints, to our knowledge, no other study on demographic characteristics and quality of life of patients with early stage unexplained complaints in general practice has been published.

Patients with unexplained complaints appear to be mainly highly educated women in their forties. They report remarkably poor levels of quality of life. Future research should explore whether and how quality of life scores and other characteristics could help in early identification of patients at risk of developing chronicity. Until then practitioners should at least be aware that early stage unexplained complaints may not always be as mild as is frequently assumed. Early stage unexplained complaints may be associated with considerable suffering on a daily basis. Awareness of potential poor quality of life may help physicians realise that they are dealing with a patient, at least, in need of more intense monitoring but maybe also of more intense treatment approaches 


\section{References}

1. Dinant $G J$, van Wijk MAM, Janssens HJEM, Somford RG, de Jager $C J$, Beusmans GHMl, Dijkstra RH, Wiersma Tj. NHG-standaard bloedonderzoek. Algemene principes en uitvoering in eigen beheer. [Dutch College of General Practitioners guideline 'Blood testing. General principles and use by GP']. Huisarts Wet 1994;37:202-11.

2. van der Weijden $T$, van Velsen $M$, Dinant $G J$, van Hasselt $C M$, Grol R. Unexplained complaints in general practice: Prevalence, patients' expectations, and professionals' testordering behavior. Med Decis Making 2003;23:226-31.

3. Kenter EG, Okkes IM. Patients with fatigue in family practice: Prevalence and treatment. Ned Tijdschr Geneeskd 1999;143:796-801.

4. Kenter EGH, Okkes IM, Oskam SK, Lamberts $\mathrm{H}$. Tiredness in Dutch family practice. Data on patients complaining of and/or diagnosed with 'tiredness'. Fam Pract 2003;20:434-440.

5. Burton C. Beyond somatisation: A review of the understanding and treatment of medically unexplained physical symptoms (MUPS). Br J Gen Pract 2003;53:231-9.

6. Katon WJ, Walker EA. Medically unexplained symptoms in primary care. $\mathrm{J}$ Clin Psychiatry 1998;59:15-21.

7. Feder A, Olfson M, Gameroff M, Fuentes M, Shea S, Lantigua RA, Weissman MM. Medically unexplained symptoms in an urban general medicine practice. Psychosomatics 2001;42: 261-8.

8. Hartz AJ, Noyes R, Bentler SE, Damiano PC, Willard JC, Momany ET. Unexplained symptoms in primary care: Perspectives of doctors and patients. Gen Hosp Psychiatry 2000;22:144-52.

9. Lundh C, Segesten K, Bjorkelund C. To be a helpless helpoholic - GPs' experiences of women patients with non-specific muscular pain. Scand J Prim Health Care 2004;22:244-7.

10. Rosendal M, Fink $P$, Bro F, Olesen F. Somatization, heartsink patients, or functional somatic symptoms? Towards a clinical useful classification in primary health care. Scand J Prim Health Care 2005;23:3-10.

11. Deary IJ. A taxonomy of medically unexplained symptoms. J Psychosom Res 1999;47:51-9.

12. Burton $\mathrm{C}$. Beyond somatisation: $\mathrm{A}$ review of the understanding and treatment of medically unexplained physical symptoms (MUPS). Br J Gen Pract 2003;53:231-9.

13. Smith GR Jr, Monson RA, Ray DC. Patients with multiple unexplained symptoms. Their characteristics, functional health, and health care utilization. Arch Intern Med 1986;146:69-72.

14. Goldberg D, Gask L, O'Dowd T. The treatment of somatization: Teaching techniques of reattribution. J Psychosom Res 1989;33:689-95.

15. Blankenstein $\mathrm{AH}$. Somatising patients in general practice. Reattribution, a promising approach (PhD Thesis) Amsterdam: Vrije Universiteit 2001.

16. Fink $P$, Rosendal $M$, Toft $T$. Assessment and treatment of functional disorders in general practice: The extended reattribution and management model-an advanced educational program for nonpsychiatric doctors. Psychosomatics 2002;43:93-131.

17. van Bokhoven MA, Koch $H$, van der Weijden T, Grol RP, Bindels PJ, Dinant GJ. Blood test ordering for unexplained complaints in general practice: The VAMPIRE randomised clinical trial protocol [ISRCTN55755886]. BMC Family Pract 2006;7:20

18. Westert GP, Schellevis FG, De Bakker DH, Groenewegen PP, Bensing JM, van der Zee J. Monitoring health inequalities through general practice: The Second Dutch National Survey of General Practice. Eur J Public Health 2005;15:59-65.

19. Ware JE, Sherbourne CD. The Mos 36-Item Short-Form Health Survey (Sf-36) .1. ConceptualFramework and Item Selection. Med Care 1992;30:473-83.

20. Westert GP, Schellevis FG, De Bakker DH, Groenewegen PP, Bensing JM, van der Zee J. Monitoring health inequalities through general practice: The Second Dutch National Survey of General Practice. Eur J Public Health 2005;15:59-65.

21. Wensing $M$, Vingerhoets $E$, Grol R. Functional status, health problems, age and comorbidity in primary care patients. Qual Life Res 2001;10:141-8. 
22. Krujjshaar ME, Hoeymans N, Bijl RV, Spijker J, Essink-Bot ML. Levels of disability in Major Depression - Findings from the Netherlands Mental Health Survey and Incidence Study (NEMESIS). J Affect Disord 2003;77:53-64.

23. Roger WH. Regression standard errors in clustered samples. Stata technical bulletin 1993;13:19-23.

24. O'Connor PJ. Evaluation of four highly cited energy and fatigue mood measures. $J$ Psychosom Res 2004;57:435-41. 


\section{Chapter 7}

The effect of watchful waiting instructions on GPs'

blood test ordering behaviour for patients with unexplained complaints; a randomised clinical trial (ISRCTN 55755886)

MA van Bokhoven, $\mathrm{H}$ Koch, $T$ van der Weijden, AHM Weekers-Muyres,

PJE Bindels, RPTM Grol, GJ Dinant

Submitted

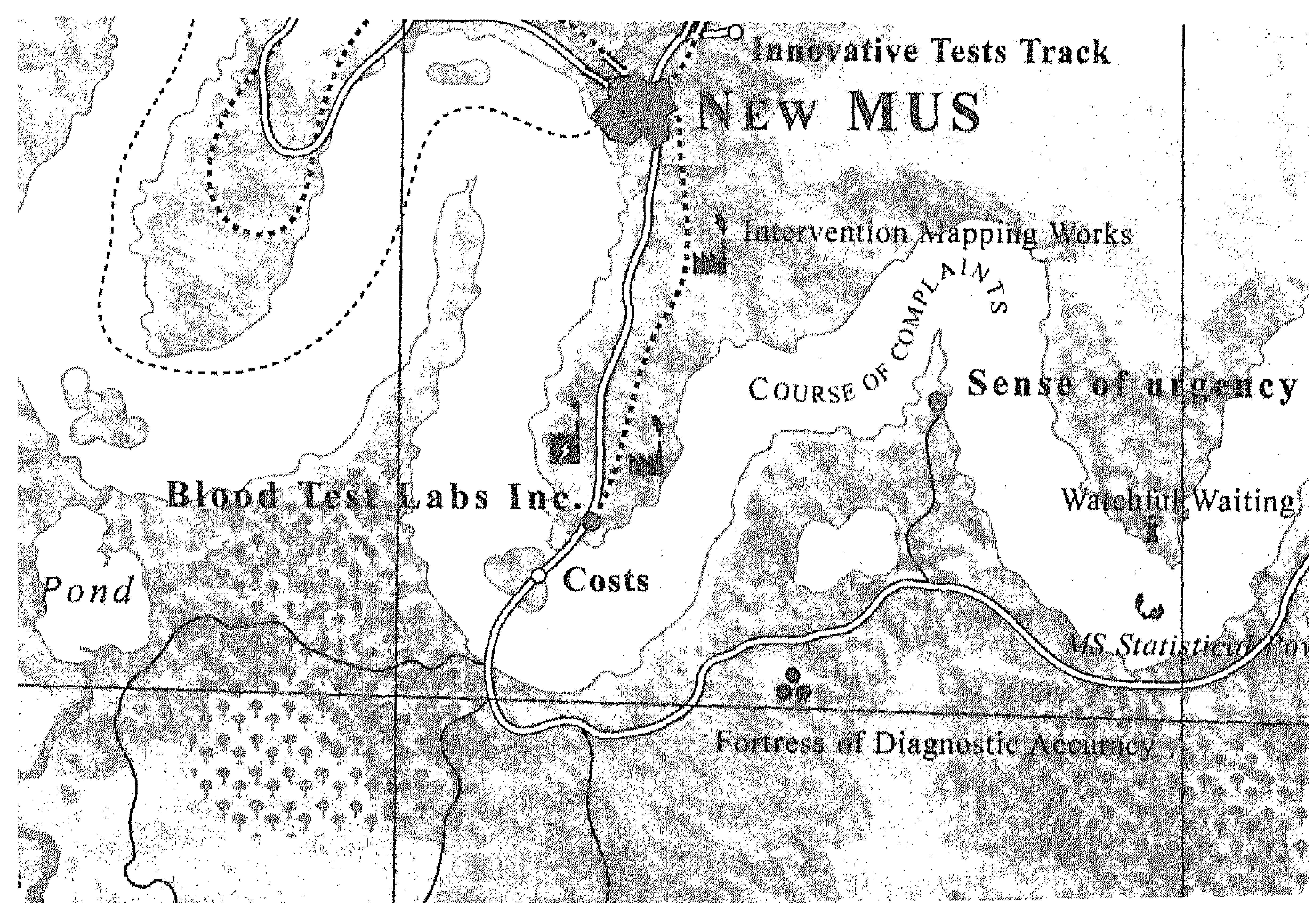




\section{Abstract}

\section{Introduction}

Immediate blood test ordering for patients presenting with unexplained complaints in general practice is superfluous from a diagnostic point of view. However, many primary care physicians order tests immediately to satisfy and reassure their patients and themselves. One strategy to reduce test ordering is to apply a watchful waiting approach, as this reduces the number of patients to be tested and the number of false-positive results.

\section{Objectives}

First, to determine the feasibility of watchful waiting, compared to immediate test ordering. Second, to determine if a systematically developed quality improvement strategy can improve this feasibility. Third, to determine if watchful waiting leads to testing at a later moment.

\section{Design}

Cluster-randomised clinical trial with 3 groups on blood test ordering strategies in patients with unexplained complaints.

\section{Intervention}

Group 1: instruction to order tests immediately; group 2: instruction to apply a watchful waiting approach; group 3: like group 2 plus support by quality improvement strategy.

\section{Participants}

498 patients with unexplained complaints from 63 GPs.

\section{Measurements}

Percentage of patients for whom tests were ordered and number of tests ordered at first consultation; performance on the strategy's performance objectives; number of tests ordered after four weeks; GP and patient characteristics.

\section{Results}

Immediate test ordering proved feasible in $92 \%$ of patients; watchful waiting in $84 \%$ and $86 \%$, respectively, for the groups with and without support of quality improvement strategy. The two watchful waiting groups did not differ significantly in the achievement of any of the performance objectives. Of the patients who returned after four weeks, none from the immediate test ordering group and six from the two watchful waiting groups had tests ordered for them.

\section{Conclusion}

Watchful waiting is a feasible approach in patients presenting with unexplained complaints. The quality improvement strategy does not improve its feasibility. Watchful waiting does not lead to testing at a later moment. 
The effect of watchiul waiting instructions on test ordering $\mid$

\section{Introduction}

'Unexplained complaints in general practice' can be defined as those complaints for which a general practitioner (GP), after clarifying the reason for encounter, taking the patient's history and performing physical examination, is unable to establish a diagnosis ${ }^{1}$. On average, $3-39 \%$ of consultations involve complaints considered unexplained by the $\mathrm{GP}^{2-4}$. The diagnostic workup for these patients frequently involves ordering blood tests, though the diagnostic accuracy of these tests is limited due to the relatively low probability of somatic pathology: less than $5 \%$ according to a rough estimate ${ }^{5}$. Due to false-positive results, this behaviour may even result in unnecessary further testing, leading to undesirable effects such as patient anxiety, somatisation or high costs.

Since most unexplained complaints are self-limiting ${ }^{1,6}$, a 4-week watchful waiting approach is expected to reduce both the number of patients to be tested and the risk of false-positive test results. However, many GPs perceive barriers against watchful waiting. Some have different testing routines, regard immediate test ordering as efficient when working under time pressure or have a low tolerance of uncertainty. Others perceive pressure from patients to order laboratory testing (even if the patient does not explicitly ask for it) or mention tactical motives for test ordering, e.g. the prevention of hospital referral or more expensive tests ${ }^{7,8}$. Thus, though watchful waiting appears to be a sound principle from a diagnostic point of view, immediate test ordering seems to be more attractive to both GPs and patients.

We designed a quality improvement strategy to promote the watchful waiting approach (Table 7.1). The strategy was developed systematically, tailored to the barriers and facilitators perceived by GPs, and resulted in specific, consultation-related performance objectives for the GPs ${ }^{9,10}$.

In this study we compared the feasibility of two approaches - watchful waiting and immediate testing - by addressing three questions. First, what is the feasibility of a watchful waiting approach compared to that of an immediate test ordering approach? Secondly, can the systematically developed quality improvement strategy improve performance in terms of the objectives of the watchful waiting approach? Thirdly, what percentage of patients are tested after an initial watchful waiting period?

The study was part of a cluster-randomised clinical trial in which the instruction to apply a watchful waiting approach, with or without the support of the quality improvement strategy, was compared with the instruction to order blood tests immediately ${ }^{11}$. 
$116 \mid$ Chapter 7

Table 7.1 Contents of quality improvement strategy.

Small group meeting 1

Part 1: Interactive explanation of diagnostic value of tests for unexplained complaints and effect of watchful waiting policy on diagnostic value.

Part 2: Discussion of difficulties experienced in practice when dealing with patients presenting with unexplained complaints.

Goal setting to change behaviour in GPs' own practice.

Small group meeting 2

Part 1: Discussion about experiences with behaviour change. Searching for solutions to barriers that have arisen.

Part 2: Practicing difficult situations by means of video vignettes.

Setting new goals to change their own behaviour.

Practice visit

Discussing barriers to change perceived by individual GPs and providing suggestions to overcome these, based on stage of change.

In between meetings, GPs get the opportunity to work on their goals to change their behaviour.

\section{Methods}

\section{Design}

The full protocol of this cluster-randomised trial has been published elsewhere ${ }^{10,11}$. To prevent contamination through patients and individual GPS, the GPs were randomised at practice level. Practices were randomised over three groups using a random number seed computer program for block randomisation. Group 1 was instructed to order blood tests immediately, groups 2 and 3 to apply a 4-week watchful waiting approach. Only group 3 was supported by our systematically developed quality improvement strategy.

The medical ethics review boards of both the Academic Medical CenterUniversity of Amsterdam and the University Hospital Maastricht approved the study.

\section{Participants}

\section{GPS}

For logistic reasons, regional laboratories in the western and southern regions of the Netherlands were asked to participate first. All GPs using the facilities of these regional laboratories were asked to participate in the trial.

\section{Patients}

The GPs were asked to enrol each consecutive eligible patient. Patients aged 18 years and older were eligible for participation if they presented with one of 
the following complaints: fatigue, abdominal complaints, weight changes, musculoskeletal complaints or itch. Their complaints needed to be unexplained according to the definition given in the Introduction section above. Patients also had to be able to read, speak and understand Dutch. Excluded were patients with unexplained complaints that caused a sense of alarm in the GP, making watchful waiting unacceptable. Patients were instructed to re-consult if their complaints had not resolved after four weeks. The patients were given written information by the GP and were asked to give informed consent.

\section{Quality improvement strategy}

The development of the strategy and its contents have been described elsewhere ${ }^{10,11}$. It consisted of two small group sessions and one practice outreach visit, whose contents have been summarised in Table 7.1. The performance objectives (Table 7.2, first column) were communicated to the GPs of group 3 during all these contacts.

Table 7.2 Performance objectives for GPs (1st column) and data collected to measure the performance (2nd column).

\begin{tabular}{|c|c|c|c|c|c|}
\hline \multirow[t]{2}{*}{$\begin{array}{l}\text { Performance } \\
\text { objective }\end{array}$} & $\begin{array}{l}\text { Question posed to } \\
\text { patients }\end{array}$ & $\begin{array}{l}\text { Answering } \\
\text { categories }\end{array}$ & $\begin{array}{c}\text { Group } 1 \\
\text { (immediate test } \\
\text { ordering) } \\
n=229 \text { patients }\end{array}$ & $\begin{array}{c}\text { Group } 2 \\
\text { (watchful waiting) } \\
n=95 \text { patients }\end{array}$ & $\begin{array}{c}\text { Group } 3 \\
\text { (watchful waiting } \\
+ \text { quality } \\
\text { improvement } \\
\text { strategy) } \\
\mathrm{n}=174 \text { patients }\end{array}$ \\
\hline & $\begin{array}{l}\text { Patients for whom } \\
\text { tests were ordered } n \\
(\%)\end{array}$ & & $210(91.7)$ & $13(13.7)$ & $27(15.5)$ \\
\hline $\begin{array}{l}\text { Ordering fewer tests } \\
\text { at the same time }\end{array}$ & $\begin{array}{l}\text { Mean number of } \\
\text { tests ordered (SD) }\end{array}$ & & $7(3.7)$ & $7(2.1)$ & $6(2.6)$ \\
\hline $\begin{array}{l}\text { Performing adequate } \\
\text { history taking and } \\
\text { physical examination }\end{array}$ & $\begin{array}{l}\text { GP performed } \\
\text { physical } \\
\text { examination \% (n) }\end{array}$ & $\begin{array}{l}\text { Sufficient } \\
\text { Not sufficient }\end{array}$ & $\begin{array}{r}124(56.9) \\
94(43.1)\end{array}$ & $\begin{array}{l}57(63.3) \\
33(36.7)\end{array}$ & $\begin{array}{l}99(62.7) \\
59(37.3)\end{array}$ \\
\hline $\begin{array}{l}\text { Explaining findings to } \\
\text { the patient }\end{array}$ & $\begin{array}{l}\text { Patient understood } \\
\text { GP's explanation of } \\
\text { the complaints } n \\
(\%)\end{array}$ & $\begin{array}{l}\text { At least } \\
\text { sufficient } \\
\text { Insufficient/ } \\
\text { unknown }\end{array}$ & $\begin{array}{r}184(84.4) \\
34(15.6)\end{array}$ & $\begin{array}{c}79(90.8) \\
8(9.2)\end{array}$ & $\begin{array}{r}139(88.5) \\
18(11.5)\end{array}$ \\
\hline Explaining that & Patient understood & Yes & $55(25.5)$ & $34(37.8)$ & $57(36.5)$ \\
\hline $\begin{array}{l}\text { findings are currently } \\
\text { not explained by } \\
\text { specific diseases }\end{array}$ & $\begin{array}{l}\text { severity of } \\
\text { complaints after the } \\
\text { consultation } \mathrm{n}(\%)\end{array}$ & No & $161(74,5)$ & $56(62.2)$ & $99(63.5)$ \\
\hline Discussing 4-week & GP discussed the & Sufficient & $153(70.2)$ & $54(60.7)$ & $81(51.3)$ \\
\hline $\begin{array}{l}\text { watchful waiting } \\
\text { approach with patient }\end{array}$ & $\begin{array}{l}\text { possibilities of } \\
\text { additional tests with } \\
\text { the patient } n(\%)\end{array}$ & $\begin{array}{l}\text { Insufficient/ } \\
\text { unknown }\end{array}$ & $65(29.8)$ & $35(39.3)$ & $77(48.7)$ \\
\hline $\begin{array}{l}\text { Asking the patient to } \\
\text { return if the } \\
\text { complaints do not } \\
\text { resolve in a month }\end{array}$ & $\begin{array}{l}\text { GP asked the } \\
\text { patient to return if } \\
\text { the complaints did } \\
\text { not disappear } n(\%)\end{array}$ & $\begin{array}{c}\text { Yes } \\
\text { No/ unknown }\end{array}$ & $\begin{array}{r}145(67.4) \\
70(32.6)\end{array}$ & $\begin{array}{l}80(88.9) \\
10(11.1)\end{array}$ & $\begin{array}{r}131(82.9) \\
27(17.1)\end{array}$ \\
\hline
\end{tabular}


$118 \mid$ Chapter 7

\section{Variables and measurements}

The primary outcome variables were the percentage of patients for whom tests were ordered and the number of tests ordered at the first consultation. Secondary outcome variables were the GPs' performance in terms of the performance objectives and the numbers of tests ordered when the patient returned after approximately four weeks. Explanatory variables were GP and patient characteristics.

When laboratory tests were ordered by the GP, either at the first consultation or when the patient returned after approximately four weeks, the research team received a copy of the test results form. The GPs were asked to order a prespecified set of tests for all patients. In addition, GPs were asked which tests they would have ordered themselves. They were also given the option of stating that they would not have ordered any tests outside the research setting.

The GPs' performance was measured in two ways; by asking the GPs to record their own performance and by asking the patients to report their experiences with regard to their GPs' behaviour (see Table 7.2, second column). At the patients' first visit, GPs filled in a complaint registration form. Each patient received a patient questionnaire with questions about their background characteristics, what happened during the consultation and their levels of satisfaction and anxiety. The questionnaire was handed out to them by the GPS at the end of the first consultation, with an envelope in which they could return the questionnaire to the research team immediately after filling it in at home.

The explanatory variables were assessed at the start of the research project by having all GPs fill in a background characteristics form.

Data were collected over a period of two years.

\section{Analysis}

Except for randomisation, variables were dichotomised, using the mean when appropriate (Table 7.2). Watchful waiting with and without quality improvement strategy (groups 3 and 2, respectively) were compared with the immediate test ordering approach (group 1). Subsequently, groups 2 and 3 were compared. The percentage of patients for whom blood tests were requested immediately was first determined per randomisation group. When GPs indicated that they would have ordered tests themselves, we also analysed the number of tests they would have ordered per consultation. Practical limitations meant that we could only analyse this for the period of one year. Subsequently, we used a bivariate analysis to evaluate if the GPs in group 3 had met the performance objectives regarding consultation skills, compared to groups 1 and 2 . Finally, we analysed the percentage of patients who had been tested after an initial watchful waiting period. All analyses used the SPSS 11 statistical software package. 


\section{Results}

\section{Participant flow and background variables}

Inclusion took place from February 2002 until December 2003. In total, 91 GPs were randomised in the study, nine of whom ended their cooperation before the inclusion started, mainly due to private circumstances and pressure of work, and 19 did not include any patients. As a result, $63 \mathrm{GPs}$ in 57 practices included 513 patients. Data about the first consultation were available for 498 patients (Figure 7.1). Fifty-two patients returned after approximately four weeks.

Background data of both GPs and patients are summarised in Tables 7.3 and 7.4. Of the $63 \mathrm{GPs}$ who included patients, 27 were in group 1 (22 practices), 14 in group 2 (14) and 22 in group 3 (21). The mean age of the participating GPs was 45 years, and $74 \%$ of them were male. The mean number of years of experience was 13 . The mean age of the patients was 43 , and $28 \%$ were male. None of the differences between the randomisation groups were statistically significant $(P>0.05)$.

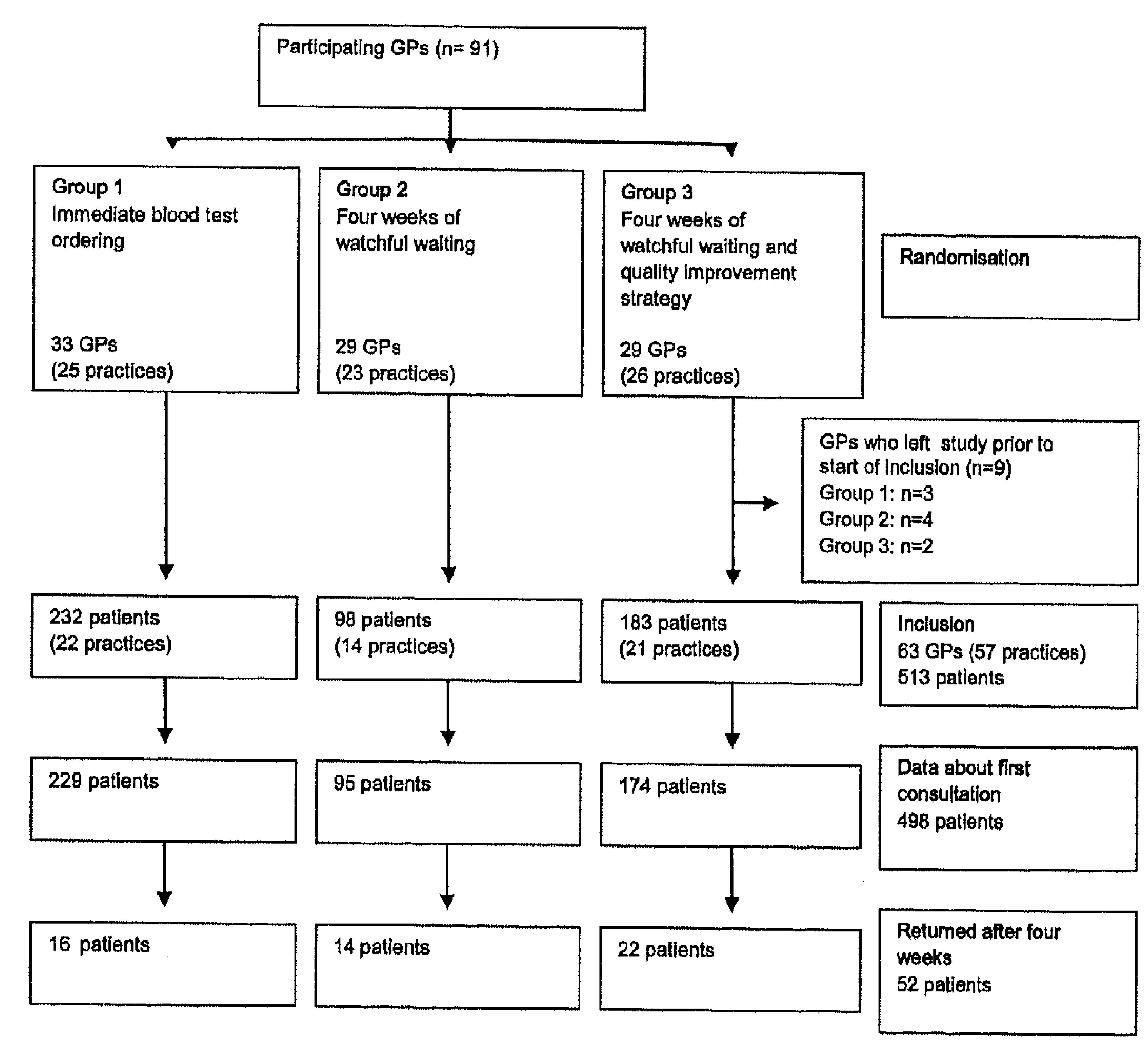

Figure 7.1 Participant flow. 
Table 7.3 Background data of participating GPs $(n=91)$

\begin{tabular}{|c|c|c|c|c|c|}
\hline \multirow[t]{2}{*}{ Variables } & \multirow[t]{2}{*}{ Categories } & \multirow{2}{*}{$\begin{array}{c}\text { Results overall } \\
n=91 \text { GPs }\end{array}$} & \multicolumn{3}{|c|}{ Randomisation } \\
\hline & & & $\begin{array}{l}\text { Immediate } \\
n=33 \text { GPs }\end{array}$ & $\begin{array}{c}\text { Watchful } \\
\text { waiting } \\
n=29 \mathrm{GPS}\end{array}$ & $\begin{array}{c}\text { Watchful } \\
\text { waiting + } \\
\text { strategy } \\
n=29 \mathrm{GPs}\end{array}$ \\
\hline Mean age years (SD) & & $45(7.3)$ & $47(5.8)$ & $44(7.2)$ & $45(8.8)$ \\
\hline $\operatorname{Sex} n(\%)$ & Male & $67(74)$ & $26(79)$ & $17(59)$ & $24(83)$ \\
\hline $\begin{array}{l}\text { Mean number of years of } \\
\text { experience as a GP (SD) }\end{array}$ & & $13(8.7)$ & $14(7.1)$ & $11(8.4)$ & $14(10.4)$ \\
\hline $\begin{array}{l}\text { Practice type (soloists } \\
\text { versus other) } n(\%)\end{array}$ & Solo & $34(37)$ & $9(27)$ & $15(52)$ & $10(34)$ \\
\hline Practice location n (\%) & $\begin{array}{c}\text { Urban } \\
\text { Semi-rural } \\
\text { Rural }\end{array}$ & $\begin{array}{l}45(50) \\
11(12) \\
34(38)\end{array}$ & $\begin{array}{r}15(47) \\
4(13) \\
13(41)\end{array}$ & $\begin{array}{r}15(52) \\
5(17) \\
9(31)\end{array}$ & $\begin{array}{r}15(47) \\
4(13) \\
13(41)\end{array}$ \\
\hline
\end{tabular}

Table 7.4 Background variables of participating patients $(n=498)$.

\begin{tabular}{|c|c|c|c|c|c|}
\hline \multirow[t]{2}{*}{ Variables } & \multirow[t]{2}{*}{ Categories } & \multirow{2}{*}{$\begin{array}{l}\text { Results overall } \\
\qquad(n=498)\end{array}$} & \multicolumn{3}{|c|}{ Randomisation $^{a}$} \\
\hline & & & $\begin{array}{l}\text { Immediate } \\
(n=229)\end{array}$ & $\begin{array}{c}\text { Watchful } \\
\text { waiting } \\
(n=95)\end{array}$ & $\begin{array}{c}\text { Watchful } \\
\text { waiting + } \\
\text { strategy } \\
(n=174)\end{array}$ \\
\hline Mean age in years $(S D)$ & & $43(16.2)$ & $42(15.5)$ & $45(15.2)$ & $45(17.5)$ \\
\hline $\operatorname{Sex}(\%)$ & Male & $140(28)$ & $67(29)$ & $18(19)$ & $55(32)$ \\
\hline $\begin{array}{l}\text { Type of health insurance: } \\
\text { private versus state }(\%)\end{array}$ & Private & $164(33)$ & $80(35)$ & $37(39)$ & $47(27)$ \\
\hline \multirow[t]{4}{*}{$\begin{array}{l}\text { Highest level of education } \\
(\%)\end{array}$} & $\begin{array}{l}\text { None } \\
\text { completed }\end{array}$ & $4(1)$ & $2(1)$ & $1(0)$ & $1(0)$ \\
\hline & Primary & $46(10)$ & $20(9)$ & $5(1)$ & $21(12)$ \\
\hline & Secondary & $323(67)$ & $146(64)$ & $65(68)$ & $112(64)$ \\
\hline & Higher & $106(22)$ & $55(24)$ & $21(22)$ & $30(17)$ \\
\hline
\end{tabular}

aifferences between groups were statistically tested with $\chi^{2}$ tests or t-test when appropriate. No statistically significant differences $(P>0.05)$ were found between the randomisation groups.

\section{Feasibility of watchful waiting}

The effects of the interventions have been summarised in Table 7.2. The watchful waiting approach was applied to $82 / 95$ patients of group $2(86 \%)$ and $147 / 174$ of group $3(84 \%)$, whereas $210 / 229$ patients in group $1(92 \%)$ were tested immediately. There was no statistically significant difference between the two watchful waiting groups in terms of the number of patients for whom tests were ordered (odds ratio (OR) $0.86,95 \% \mathrm{Cl} 0.42-1.76$ ). 
The effect of watchful waiting instructions on test ordering $\mid \begin{aligned} & 121 \\ & \text {. }\end{aligned}$

\section{Performance objectives}

Groups 2 and 3 did not differ significantly as regards meeting any of the performance objectives (Table 7.5). A comparison of watchful waiting with immediate test ordering showed that there were no significant differences between group 1 versus groups 2 and 3 in terms of the performance objectives 'GP orders fewer tests', 'GP performs adequate physical examination' and 'GP explains findings to patient'. When compared to group 1, the GPs in group 3 had lower scores on the item 'GP discusses the value of additional tests' (OR $0.495 \%$; $\mathrm{Cl} 0.3-0.7)$ ). GPs in the watchful waiting groups had better scores for knowledge about the severity of the complaints and for the objective 'GP asks the patient to return if the complaints do not disappear within a month' (Table 7.5).

Table 7.5 Odds ratios (confidence intervals) of differences in meeting performance objectives between groups.

\begin{tabular}{|c|c|c|c|}
\hline Question to patient & Group 2 vs. group 1 & Group 3 vs, group 1 & Group 2 vs. group 3 \\
\hline $\begin{array}{l}\text { Patients with tests } \\
\text { ordered }\end{array}$ & N/A & N/A & $N / A$ \\
\hline $\begin{array}{l}\text { Mean number of tests } \\
\text { ordered }\end{array}$ & N/A & N/A & $N / A$ \\
\hline $\begin{array}{l}\text { GP performed physical } \\
\text { examination }\end{array}$ & $1.3(0.8-2.2)$ & $1.3(0.8-1.9)$ & $1.0(0.6-1.8)$ \\
\hline $\begin{array}{l}\text { Patient understood GP's } \\
\text { explanation of the } \\
\text { complaints } n(\%)\end{array}$ & $1.8(0.8-4.1)$ & $1.4(0.8-2.6)$ & $1.3(0.5-3.1)$ \\
\hline $\begin{array}{l}\text { Patient understood } \\
\text { severity of complaints } \\
\text { after the consultation }\end{array}$ & $1.8(1.1-3.0)^{\mathrm{a}}$ & $1.7(1.1-2.6)^{\mathrm{a}}$ & $1.1(0.6-1.8)$ \\
\hline $\begin{array}{l}\text { GP discussed the } \\
\text { possibilities of additional } \\
\text { tests with the patient }\end{array}$ & $0.7(0.4-1.1)$ & $0.4(0.3-0.7)^{\mathrm{a}}$ & $1.5(0.9-2.5)$ \\
\hline $\begin{array}{l}\text { GP asked the patient to } \\
\text { return if the complaints } \\
\text { did not disappear }\end{array}$ & $3.8(1.9-7.9)^{\mathrm{a}}$ & $2.3(1.4-3.9)^{\mathrm{a}}$ & $1.6(0.8-3.6)$ \\
\hline
\end{tabular}

\section{Testing after watchful waiting}

At the first consultation, GPs ordered a mean of seven tests in groups 1 and 2 , and six in group 3. After the watchful waiting period of approximately four weeks, GPs in group 1 would not have ordered tests themselves for any patient. In group 2, 1 patient had six tests ordered, and in group 3, five patients had a mean of nine tests ordered for them. 


\section{Discussion}

Our findings show that watchful waiting is a feasible approach for patients presenting with unexplained complaints in general practice. However, our quality improvement strategy did not improve the feasibility of a watchful waiting approach any further, nor did it improve the GPs' consultation skills. After an initial watchful waiting period, laboratory testing was rarely used at a later moment. This was predominantly caused by the fact that not many patients returned. The instruction to apply a watchful waiting approach, with or without additional training, was thus an effective way to reduce test ordering.

The lack of effect of the quality improvement strategy might be explained by the fact that the room for improvement was very limited, given the good feasibility of watchful waiting even without GPs being exposed to the quality improvement strategy. On the other hand, the strategy may not have had the intended effect. Given the positive attitude regarding immediate test ordering and lack of perceived disadvantages, the GPs may have lacked a sense of urgency to change their blood test ordering behaviour ${ }^{7}$.

In terms of consultation skills, it appears that GPs who apply a watchful waiting approach replace testing by explanations about the complaints. This can be considered a positive effect because it may favourably influence the patients' satisfaction and anxiety ${ }^{12,13}$. The value of additional tests was more frequently discussed in group 1 than in groups 2 and 3 . However, it is questionable whether the GPs in group 1 discussed the advantages of a watchful waiting approach, including the limitations of laboratory tests, as was intended by the performance objective. The difference between the groups appears to have been due to the different wording of the performance objective used in the patient questionnaire ('GP discussed the possibilities of additional tests with the patient'), because we wanted to blind the patients to the specific test ordering strategies we wanted to study. Finally, GPs in the watchful waiting groups more frequently asked patients to return if the complaints should persist than those in group 1. The behaviour of group 1 may have an important disadvantage. Unspecified testing carries not only the risk of false-positive tests, but also that of false-negative results. In the literature it has been repeatedly suggested that patients may be incorrectly reassured by negative test results and consequently may not return even if their complaints persist, which may cause a diagnostic delay. Empirical evidence is limited, though ${ }^{14-18}$.

One strength of the present study was that, as far as we know, it represents the first time that a watchful waiting approach has been studied as a diagnostic strategy. So far, the approach of delaying further action has only been described in studies on therapy and monitoring. An example of its use in therapy is the prescription of antibiotics with the instruction only to start taking them when the complaints last for a specified time or become severe enough. 
This is called 'delayed prescribing' ${ }^{19,20}$. An example of the use in monitoring, which is usually also described by the term 'watchful waiting' is to monitor the levels of prostate-specific antigen in patients with prostate carcinoma. Only when they rise to a certain level are therapeutic interventions started.

Another strong point was that our systematically developed quality improvement strategy was also systematically evaluated, by taking into account the performance objectives as intermediate outcome measures.

A limitation of the study was that selective patient inclusion may have caused bias. The GPs of group 2 (watchful waiting without quality improvement strategy) included fewer patients in the study than those of other groups. This seems to have been due to a number of GPs in this group who did not include any patients; if these GPs are omitted from the analysis, no statistically significant difference in patient inclusion remains between the groups. Our explanation is that GPs hesitated to start asking patients to participate because they did not have any diagnostic tests to offer them which could serve as a 'reward' for participation. If this was indeed the case, GPs in groups 2 and 3 should have included fewer patients. However, GPs in group 3 had participated in several training sessions in which they discussed the limited value of immediate test ordering and the effects of watchful waiting. Therefore, GPs in group 3 may have felt more confident about convincing patients to participate. To prevent selective inclusion, the GPs were allowed to order tests immediately if they felt it would be wrong to postpone testing, and they were asked to explain their reasons on a special form. They mentioned three types of reasons: their own sense of alarm $(n=10)$, the requests by patients or their relatives to have tests done $(n=7)$ and the findings from a patient's background, history and physical examination $(n=7)$. Although we have no indications of selective inclusion, we cannot completely exclude it either. A non-inclusion analysis is hardly possible, since unexplained complaints are not registered as such in the patient records by the GPs.

In conclusion, this study shows that watchful waiting is a feasible approach in patients with unexplained complaints and that it does not lead to testing at a later moment. However, the diagnostic value of immediate testing compared to the watchful waiting approach needs to be taken into account when drawing definitive conclusions on the desirability of watchful waiting. Further research is needed to determine if the approach will actually be used in daily practice routine, in which the advantages of immediate test ordering in the interaction with patients may outweigh the advantages of evidence-based test ordering behaviour. Given the high level of feasibility found in the present experimental setting, further research seems worthwhile. 


\section{References}

1. Dinant GJ, van Wijk MAM, Janssens HJEM, Somford RG, de Jager CJ, Beusmans GHMI, Dijkstra RH, Wiersma Tj. NHG-standaard bloedonderzoek. Algemene principes en uitvoering in eigen beheer. [Dutch College of General Practitioners guideline 'Blood testing. General principles and use by GP']. Huisarts Wet 1994;37:202-11.

2. van der Weijden $T$, van Velsen M, Dinant $G J$, van Hasselt $C M$, Grol RPTM. Unexplained complaints in general practice. Prevalence, patients' expectations, and professionals' testordering behavior. Med Decis Making 2003;23:226-31.

3. Burton $\mathrm{C}$. Beyond somatisation: a review of the understanding and treatment of medically unexplained physical symptoms (MUPS). Br J Gen Pract 2003;53:231-41.

4. Peveler R, Kilkenny $L$, Kinmonth A-L. Medically unexplained physical symptoms in primary care: A comparison of selfreport screening questionnaires and clinical opinion. J Psychosom Res 1997;42:245-52.

5. Hindmarsh JT, Lyon AW. Strategies to promote rational clinical chemistry test utilization. Clin Biochem 1996;29:291-9.

6. Kenter $E$, Okkes I, Oskam S, Lamberts $H$. Tiredness in Dutch family practice. Data on patients complaining of and/or diagnosed with 'tiredness'. Fam Pract 2003;20:434-40.

7. van der Weijden $T$, van Bokhoven MA, Dinant $G J$, van Hasselt $C M$, Grol RPTM. Understanding laboratory testing in diagnostic uncertainty: a qualitative study in general practice. Br J Gen Pract 2002;52:974-80.

8. Hartley RM, Epstein AM, Harris CM, McNeil BJ. Differences in ambulatory test ordering in England and America. Role of doctors' beliefs and attitudes. Am J Med 1987;82:513-7.

9. Bartholomew LK, Parcel GS, Kok G. Intervention mapping: a process for developing theoryand evidence-based health education programs. Health Educ Behav 1998;25:545-63.

10. van Bokhoven MA, Kok $G$, van der Weijden $T$. Designing a quality improvement intervention: a systematic approach. Qual Saf Health Care 2003;12:215-20.

11. van Bokhoven MA, Koch $H$, van der Weijden T, Bindels PJE, Grol RPTM, Dinant GJ. Blood test ordering for unexplained complaints in general practice, the VAMPIRE randomised clinical trial protocol. [ISRCTN55755886]. BMC Fam Pract 2006;7:20.

12. Jung HP, Wensing $M$, Grol $R$. What makes a good general practitioner: do patients and doctors have different views? Br J Gen Pract 1997;47:805-9.

13. Peck BM, Asch DA, Goold SD, Roter DL, Ubel PA, Mcintyre LM, Abbott KH, Hoff JA, Koropchak CM. Tulsky JA. Measuring patient expectations: does the instrument affect satisfaction or expectations? Medical care 2001;39:100-8.

14. Ahlquist DA. Fecal occult blood testing for colorectal cancer. Can we afford to do this? Gastroenterol Clin North Am 1997;26:41-55.

15. Deutekom $M$, Bossuyt PM. De toegenomen beschikbaarheid van doe-het-zelftests voor medische metingen. [The increased availability of self-tests for medical analyses]. Ned Tijdschr Geneesk 2007;151:901-4.

16. LeGrys VA, Wood RE. Incidence and implications of false-negative sweat test reports in patients with cystic fibrosis. Pediatr Pulmonol 1988;4:169-72.

17. Yeh $M W$, Demircan $O$, Ituarte $P$, Clark $\mathrm{OH}$. False-negative fine-needle aspiration cytology results delay treatment and adversely affect outcome in patients with thyroid carcinoma. Thyroid 2004;14:207-15.

18. Petticrew $M$, Sowden $A$, Lister-Sharp D. False-negative results in screening programs. Medical, psychological, and other implications. Int J Technol Assess Health Care 2001; 17:164-70.

19. Little $P$, Gould $C$, Williamson I, Moore M, Warner G, Dunleavy J. Pragmatic randomised controlled trial of two prescribing strategies for childhood acute otitis media. BMJ. 2001; 322:336-42.

20. Arroll $B$, Kenealy $T$, Kerse N. Do delayed prescriptions reduce antibiotic use in respiratory tract infections? A systematic review. Br J Gen Pract 2003;53:871-7. 


\section{Chapter 8}

The influence of a watchful waiting approach on satisfaction and anxiety among patients presenting with unexplained complaints in family practice

MA van Bokhoven, H Koch, T van der Weijden, RPTM Grol, AD Kester, PELM Rinkens, PJE Bindels, GJ Dinant

Submitted

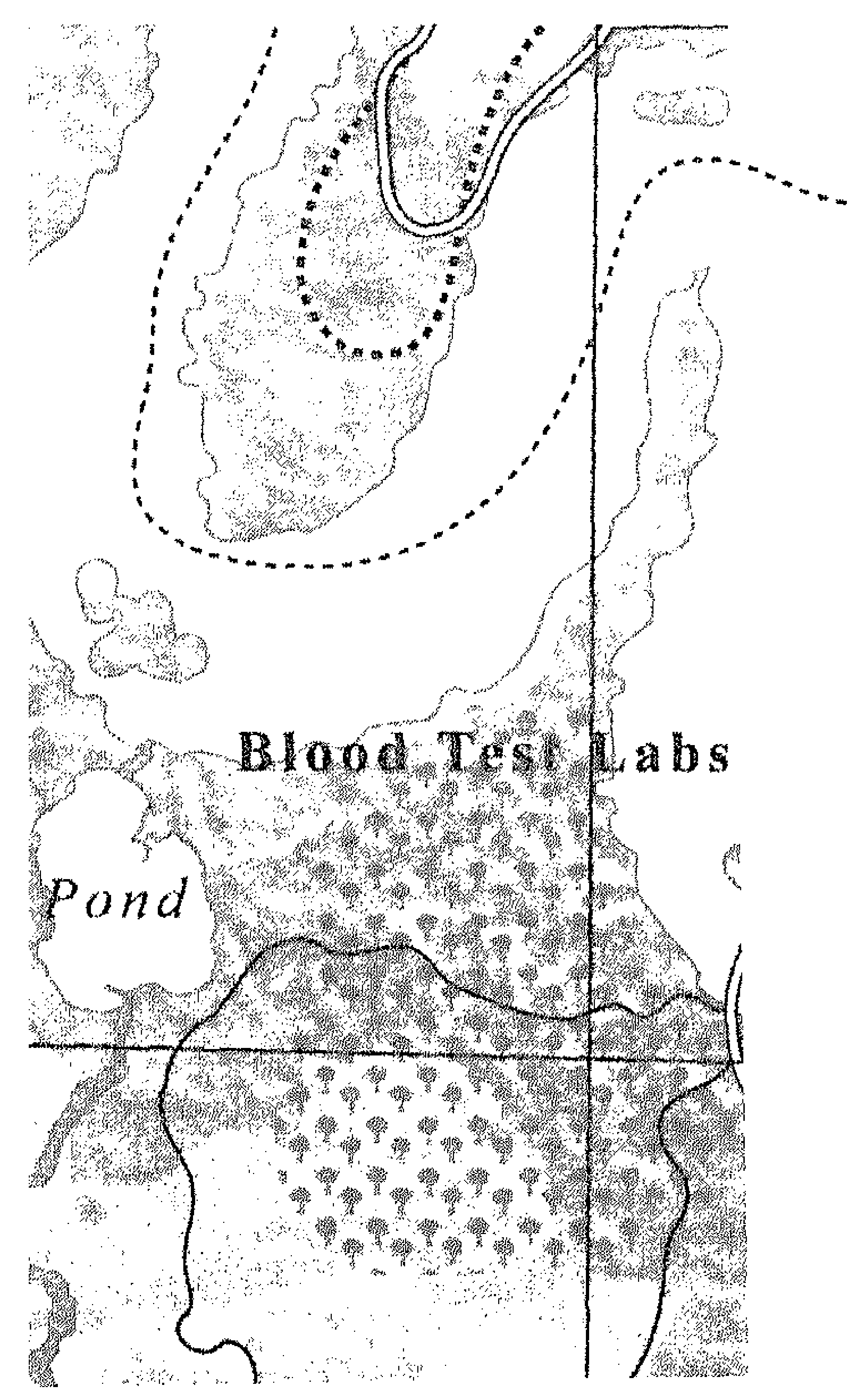




\section{Abstract}

\section{Introduction}

Immediate blood test ordering for patients presenting with unexplained complaints in general practice is superfluous from a diagnostic point of view. One strategy to reduce blood testing is to apply a watchful waiting approach. However, many primary care physicians order tests immediately to satisfy and reassure their patients. It is unclear if watchful waiting is acceptable to patients, especially in the light of long-term physician-patient relationships and prevention of malpractice suits.

\section{Objective}

To determine if test-ordering strategy and other consultation-related factors influence satisfaction with and anxiety after the consultation among patients with unexplained complaints.

\section{Design}

Cluster-randomized clinical trial on blood test ordering strategies in patients with unexplained complaints.

Participants: 498 patients with unexplained complaints from 63 primary care physicians.

\section{Measurements}

Physician and patient questionnaires about background characteristics, satisfaction with care, anxiety and aspects of the consultations (signs, symptoms and communication). Laboratory test results forms.

\section{Results}

Mean satisfaction with and anxiety after the consultation (10-point scale) were 7.3 and 3.1 , and did not differ between randomization groups ( $X^{2} 2.4$ and 0.3 respectively). Factors relating to satisfaction (e.g. patients feeling taken seriously and physicians discussing testing) and to anxiety (e.g. patients feeling dissatisfied with the consultation and not knowing the seriousness of their complaints afterwards) mainly concerned physician-patient communication.

\section{Conclusions}

Test-ordering strategy does not influence patients' satisfaction with and anxiety after the consultation. Instead, specific aspects of physician-patient communication are important. Apparently, primary care physicians underestimate how much they can contribute to the wellbeing of their patients by discussing their worries. 


\section{Introduction}

'Unexplained complaints in primary care' can be defined as those complaints for which a primary care physician, after clarifying the reason for encounter, taking the patient's history and performing physical examination, is unable to establish a diagnosis ${ }^{1}$. Unexplained complaints are rather prevalent, especially in general practice; on average, $3-39 \%$ of consultations involve complaints considered unexplained by the primary care physician ${ }^{2-5}$. In many cases, blood tests are ordered for these patients, though the diagnostic accuracy of such tests is limited due to the relatively low probability of somatic pathology: less than $5 \%$ according to a rough estimate ${ }^{6,7}$. This may result in unnecessary further testing, leading to unfavorable effects such as patient anxiety, high costs, somatisation and morbidity. Since testing in such situations is thus superfluous from a diagnostic point of view, several strategies have been promoted to reduce test ordering $^{8,9}$. One of these is using a watchful waiting approach ${ }^{1}$. In therapeutics, this approach is known as 'delayed prescribing', and is mainly used for antibiotic prescriptions ${ }^{10,11}$. This strategy has proved effective in reducing the use of antibiotics. In diagnostics, this approach is mainly limited to the follow-up of high values of prostate-specific antigen without starting therapeutic interventions like radiotherapy or prostatectomy ${ }^{12}$. In unexplained complaints, which are usually self-limiting, this approach is thought to reduce the number of patients tested and to improve the predictive values of tests in patients tested after a watchful waiting period.

However, primary care physicians mention various reasons to order tests, other than diagnostic reasons, an important one being patient requests ${ }^{13,14}$.

Patients appear to ask for tests, and primary care physicians feel that testing is an efficient way to reassure them ${ }^{13-15}$. Satisfying and reassuring patients appear to be two important goals, especially in the light of the long-term relationships between primary care physicians and patients and the prevention of malpractice suits $^{16,17}$. The literature shows that many patients do indeed expect blood tests to be ordered, and have high expectations about the value of such tests 3 ,18,19. Their satisfaction about the care they receive may largely depend on it. However, it remains unclear whether testing does indeed influence patients' satisfaction with care. Some studies show that patients consider other aspects of care more important, such as being listened to and getting a clear explanation about the nature of their problem ${ }^{20,21}$. In other studies, patients stated that they would be very dissatisfied if their expectations were not met $^{18,22-24}$. None of these studies specifically looked at unexplained complaints, however.

The literature provides little support for patient reassurance as a reason for test ordering. Qualitative studies have shown that patients may be uncomfortable with clinical uncertainty, and that they expect to obtain definite information about 
their health from test results ${ }^{18,22}$. Reassurance is recognized as an important aspect of the physician-patient relationship, which in turn is a dimension of patient satisfaction ${ }^{25,26}$. A review of the concepts of patient satisfaction concluded, however, that a direct association of reassurance with satisfaction remains unproven ${ }^{27}$.

In summary, whereas reducing superfluous testing by using a watchful waiting approach seems a matter of rational decision-making, it remains questionable if it is acceptable to patients. The test-ordering strategy may influence both patient satisfaction and anxiety, which appear to be distinct issues. We hypothesized that watchful waiting would decrease patient satisfaction and would increase patient anxiety.

The objective of this study was to use quantitative methods to determine if direct test ordering, compared to watchful waiting, influences satisfaction with and anxiety after the consultation among patients with unexplained complaints. We also wanted to relate the test-ordering strategy to other factors concerning the primary care physician/practice, the patient and the complaints/consultation.

\section{Methods}

\section{Design}

The study was part of a cluster-randomized clinical trial on blood test ordering in patients with unexplained complaints, using the primary care physicians' practices as the level of randomization. Participating general practices were randomized over three groups using a computer-generated blockwise randomization list (Figure 8.1). Primary care physicians in group 1 were instructed to order blood tests immediately at the first consultation. Those in group 2 were instructed to propose a watchful waiting approach to their patients. The primary care physicians in group 3 were also instructed to try and postpone test ordering, but at the same time they participated in a quality improvement strategy that supported them in postponing test ordering for patients with unexplained complaints. The full protocol of this study, addressing all criteria for the reporting of randomized clinical trials (CONSORT statement), has been published elsewhere ${ }^{28}$. The medical ethics committees of both the Academic Medical Center-University of Amsterdam and the University Hospital Maastricht have approved the study.

\section{Setting}

General practices in the southern and western provinces of the Netherlands. Both single-doctor and group practices could participate. 


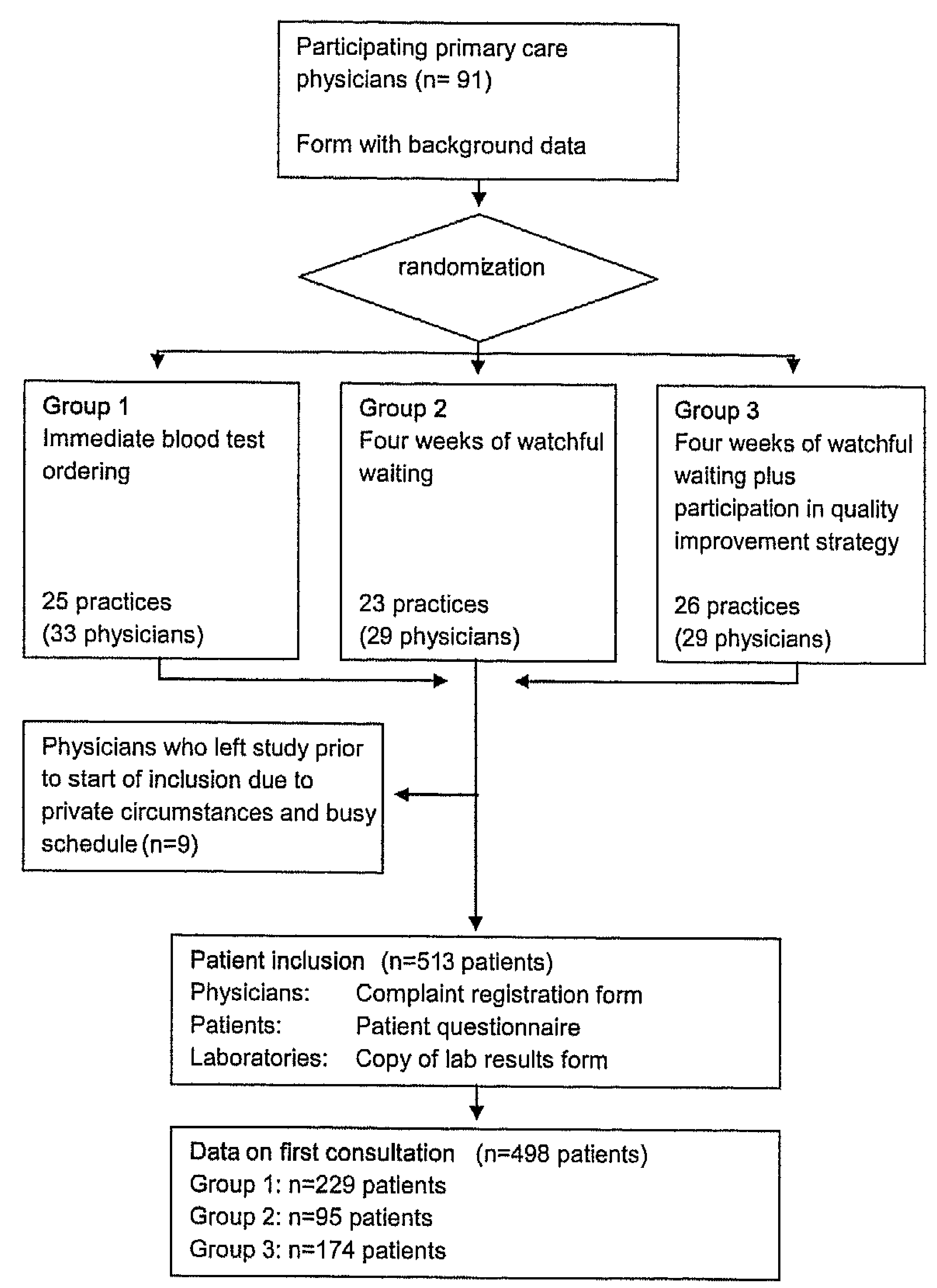

Figure 8.1 Randomization scheme, numbers of participants and questionnaires used.

\section{Participants}

Patients aged 18 years and older, presenting with a complaint that remained unexplained after history taking and physical examination according to their primary care physician, were eligible to participate. The types of complaints were limited to the following five: fatigue, abdominal complaints, musculoskeletal complaints, weight change or itch. Patients also had to be able to read, 
$130 \mid$ Chapter 8

speak and understand Dutch. Excluded were patients with unexplained complaints that caused a sense of alarm in the primary care physician, making watchful waiting unacceptable. The primary care physicians were asked to enroll each consecutive eligible patient. Written information was given to the patients and they were asked to give informed consent.

\section{Measurements}

The data analyzed in this paper were derived from the consultation at which a patient was enrolled in the study. The variables are summarized in Table 8.1.

\begin{tabular}{|c|c|c|}
\hline Instrument & Completed by & Variables \\
\hline $\begin{array}{l}\text { Primary care physicians' } \\
\text { background data }\end{array}$ & Primary care physicians & $\begin{array}{l}\text { Demographic data } \\
\text { Practice characteristics } \\
\text { Continuing medical education } \\
\text { Laboratory facilities available in practice }\end{array}$ \\
\hline $\begin{array}{l}\text { Complaint registration form } \\
\text { (for each individual type of } \\
\text { complaint) }\end{array}$ & Primary care physicians & $\begin{array}{l}\text { Symptoms } \\
\text { Signs } \\
\text { Working hypothesis } \\
\text { Degree of unexplainedness } \\
\text { Degree of suspicion of serious pathology } \\
\text { Degree of insecurity of primary care } \\
\text { physician } \\
\text { Satisfaction of primary care physician }\end{array}$ \\
\hline Patients' background data & Patients & $\begin{array}{l}\text { Demographic data } \\
\text { Type of health insurance } \\
\text { Level of education }\end{array}$ \\
\hline Patient questionnaire & Patients & $\begin{array}{l}\text { Intensity of complaints } \\
\text { Course of complaints } \\
\text { Satisfaction with care } \\
\text { Anxiety }\end{array}$ \\
\hline Test results form & Laboratory & Blood test results \\
\hline
\end{tabular}

We collected data about the characteristics of the primary care physician/practice, the characteristics of the patient and the presented consultation. Participating primary care physicians completed a background characteristics form after they had agreed to participate. When a patient was enrolled in the study, the primary care physician filled in a complaint registration form and the patient was given a questionnaire to take home, fill in and return to the research group immediately after the consultation, in a stamped envelope. When blood tests were ordered, a copy of the test results form was sent directly to the research group by the laboratory facility. Patients' satisfaction with and anxiety after the consultation were measured using the following questions: 'How satisfied are you about the visit that you just paid to the primary care 
physician?', 'How anxious are you after the visit you just paid to the primary care physician?'. Both questions had a $0-10$ scale, with 0 meaning dissatisfaction or absence of anxiety and 10 meaning total satisfaction or extreme anxiety. Patients were also asked about their general satisfaction with the primary care physician and their anxiety before the consultation (0-10 scale). The latter was assessed after the consultation by asking the patients to imagine the moment they were in the waiting room before the consultation and remember how anxious they had felt at that moment.

\section{Statistical analysis}

Except for randomization and duration of complaints, variables were dichotomized, using the mean or the median, where appropriate (see appendices). Patient satisfaction and anxiety were dichotomized because of their non-parametrical distribution.

Level of satisfaction with and anxiety after the consultation were determined per randomization group and overall. We also analyzed the relation between tests being ordered and satisfaction or anxiety.

We did a bivariate analysis with patient satisfaction with the consultation and patient anxiety after the consultation as the dependent variables, and variables relating to the randomization, the characteristics of the primary care physician/practice, the characteristics of the patient and the presented complaints/consultation as the independent variables, using the SPSS 11 statistical software package.

Independent background characteristics with a bivariate $p$-value $\leq 0.1$ were entered in a backwards multilevel logistic regression analysis to correct for possible confounding (STATA 8 statistical software package). We used a random intercept for the practice level and retained the 'randomization' variable (group 1,2 or 3 ) in the model. Subsequently, we added variables that might influence satisfaction, and anxiety and repeated the analysis. Results are presented as adjusted odds ratios.

\section{Results}

Participants' flow and background variables.

Inclusion took place from February 2002 until December 2003. In total, 91 primary care physicians were randomized in the study, nine of whom ended their participation before the inclusion started, mainly due to private circumstances and a busy practice schedule, while 19 did not include any patients. In the end, 63 primary care physicians included 513 patients. Data 
$132 \mid$ Chapter 8

about the first consultation were available for 498 patients (Figure 8.1). Background characteristics for both primary care physicians and patients are summarized in Tables 8.2 and 8.3. Of the 63 GPs who included patients, 27 in group 1 (22 practices), 14 in group 2 (14) and 22 in group 3 (21). The mean age of the participating GPs was 45 years (SD 7.3), and $74 \%$ were male. They had a mean of 13 years of experience (SD 8.7). The mean age of the patients was 43 years (SD 16.2) and $28 \%$ were male.

Table 8.2 Background data of participating primary care physicians ( $n=91)$.

\begin{tabular}{|c|c|c|c|c|c|}
\hline \multirow[t]{2}{*}{ Variables } & \multirow[t]{2}{*}{ Categories } & \multirow[t]{2}{*}{ Results overall } & \multicolumn{3}{|c|}{ Randomization } \\
\hline & & & Direct & $\begin{array}{c}\text { Watchful } \\
\text { waiting }\end{array}$ & $\begin{array}{l}\text { Watchful } \\
\text { waiting + } \\
\text { strategy }\end{array}$ \\
\hline $\begin{array}{l}\text { Mean age } \\
\text { years (SD) }\end{array}$ & & $45(7.3)$ & $47(5.8)$ & $44(7.2)$ & $45(8.8)$ \\
\hline $\operatorname{Sex} n(\%)$ & Male & $67(74)$ & $26(39)$ & $17(25)$ & $24(36)$ \\
\hline $\begin{array}{l}\text { Mean number of years of } \\
\text { experience as a primary care } \\
\text { physician (SD) }\end{array}$ & & $13(8.7)$ & $14(7.1)$ & $11(8.4)$ & $14(10.4)$ \\
\hline $\begin{array}{l}\text { Single-doctor versus other } \\
\text { practices } n(\%)\end{array}$ & Solo & $57(63)$ & $9(27)$ & $15(44)$ & $10(29)$ \\
\hline $\begin{array}{l}\text { Practice region west versus } \\
\text { south } n(\%)\end{array}$ & West & $44(48)$ & $19(43)$ & $11(25)$ & $14(32)$ \\
\hline Practice location & Urban & $45(50)$ & $15(33)$ & $15(33)$ & $15(33)$ \\
\hline \multirow[t]{2}{*}{$n(\%)$} & Semi-rural & $11(12)$ & $4(36)$ & $5(46)$ & $2(18)$ \\
\hline & Rural & $34(38)$ & $13(38)$ & $9(27)$ & $12(35)$ \\
\hline $\begin{array}{l}\text { Mean number of topics done } \\
\text { during continuing medical } \\
\text { education (CME) (SD) }\end{array}$ & & $1.9(1.6)$ & $1.9(1.6)$ & $2.3(1.1)$ & $1.5(1.6)$ \\
\hline $\begin{array}{l}\text { Mean number of avallable } \\
\text { laboratory tests in own } \\
\text { practice (SD) }\end{array}$ & & $2.4(1.1)$ & $2.4(1.2)$ & $1.9(1.0)$ & $2.6(0.9)$ \\
\hline
\end{tabular}

\section{Satisfaction and anxiety}

Mean satisfaction of patients with the consultation on a 10-point scale was 7.3 (SD 2.0). Mean anxiety after the consultation was 3.1 (SD 2.5). No statistically significant differences were found between the three randomization groups (Table 8.3). Whether or not blood tests were ordered did not cause a statistically significant difference either (OR1.2; $95 \% \mathrm{Cl}$ : 0.8-1.7). Multivariate analysis showed no confounders. 


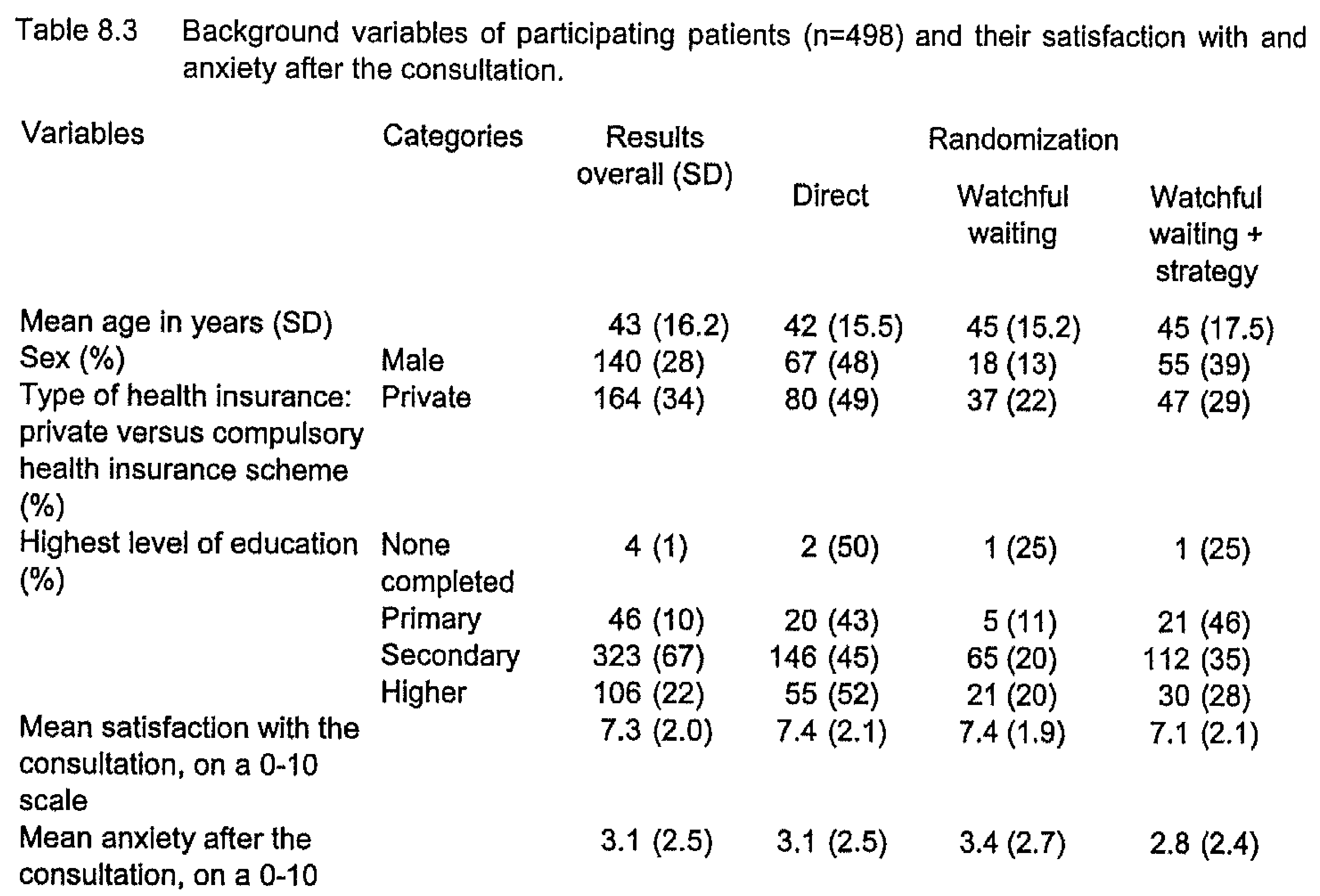

Relation between patient satisfaction or anxiety and laboratory test ordering

The appendices, summarize determinants that were significant at $p \leq 0.1$ in the bivariate analysis (appendices 1 and 2). Satisfaction was influenced neither by the randomization group $\left(X^{2} 2.4\right)$ nor by laboratory test ordering (OR 1.3; $95 \% \mathrm{Cl}: 0.9-1.8)$. The same was true for patient anxiety, with a $X^{2}$ value of 0.3 and an OR of $1.2(95 \% \mathrm{Cl}: 0.8-1.7)$.

\section{Determinants related to patient satisfaction and anxiety}

Tables 8.4 and 8.5 show the adjusted odds ratios for the variables in the multivariate analysis. Analyses were done while retaining the 'randomization' variable in the model, but it was of limited influence. The intra-cluster correlation coefficient of the practice level was low (see Tables 8.4 and 8.5 ). 
$134 \mid$ Chapter 8

Table 8.4 Results of the multivariate, multilevel logistic regression analysis, with patient satisfaction with the consultation as the dependent variable. Randomization (2 dummies) was retained in the model.

\begin{tabular}{|c|c|c|}
\hline Variable & Categories & $\begin{array}{l}\text { Adjusted odds ratio } \\
(95 \% \mathrm{Cl})\end{array}$ \\
\hline Randomization & 1 direct test ordering & \\
\hline Group 2 & 2 watchful waiting & $0.84(0.39-1.82)$ \\
\hline Group 3 & $\begin{array}{l}3 \text { watchful waiting plus quality } \\
\text { improvement strategy }\end{array}$ & $0.91(0.48-1.72)$ \\
\hline $\begin{array}{l}\text { General satisfaction with } \\
\text { primary care physician }\end{array}$ & $\begin{array}{l}1 \text { above average } \\
2 \text { below average }\end{array}$ & $14.39(7.63-27.1$ \\
\hline Patient felt taken seriously & $\begin{array}{l}1 \text { at least sufficiently } \\
2 \text { insufficiently / somewhat / unknown }\end{array}$ & $7.56(1.88-30$ \\
\hline $\begin{array}{l}\text { Primary care physician } \\
\text { discussed laboratory testing } \\
\text { with patient, according to patient }\end{array}$ & $\begin{array}{l}1 \text { yes } \\
2 \text { no or unknown }\end{array}$ & $2.28(1.28-4.07)$ \\
\hline $\begin{array}{l}\text { Patient knew seriousness of } \\
\text { complaints after the consuitation }\end{array}$ & $\begin{array}{l}1 \text { yes } \\
2 \text { no }\end{array}$ & $2.07(1.18-3.63)$ \\
\hline Age of primary care physician & $\begin{array}{l}1 \leq 46 \text { years } \\
2 \geq 47 \text { years }\end{array}$ & $0.47(0.26-0.84)$ \\
\hline $\begin{array}{l}\text { Bearableness according to } \\
\text { primary care physician } \\
\text { Intra cluster coefficient }\end{array}$ & $\begin{array}{l}1 \text { bearable } \\
2 \text { unbearable }\end{array}$ & $0.30(0.11-0.78)$ \\
\hline
\end{tabular}

Patients with unexplained complaints felt more satisfied with the consultation when they were satisfied with their primary care physician in general (OR 14.39), when they felt they had been taken seriously (OR 7.56), when, in their opinion, the physician had discussed lab testing with them (OR 2.28), and when they thought they knew how serious their complaints were after the consultation (OR 2.07). They felt less satisfied when their primary care physician was younger (OR 0.47 ) and when the primary care physician thought the complaints were bearable for the patient (OR 0.30).

Anxiety after the consultation was higher when patients had already been anxious before the consultation (OR 6.83), when patients wished to be referred to a specialist (OR 2.43) or expected blood tests to be ordered (OR1.84) and when the primary care physician did a physical examination during the consultation (OR 2.03). It was also higher when the physician felt certain that there was no cause for alarm (OR 2.37) or took a special interest in psychosocial and unexplained complaints (OR 2.21). The anxiety was lower when the patients themselves considered their complaints bearable (OR 0.56), when they felt satisfied with the consultation (OR 0.53) and when they thought they knew how serious their complaints were after the consultation (OR 0.45). We analyzed the presence of interaction terms. The 'randomization' variable may have interacted with the 'patient felt taken seriously' variable, but further statistical analysis was impossible due to the small size of one of the cells. 
Table 8.5 Results of the multivariate, multilevel logistic regression analysis, with patient anxiety after the consultation as the dependent variable. Randomization (2 dummies) was retained in the model.

\begin{tabular}{|c|c|c|}
\hline Variable & Categories & $\begin{array}{l}\text { Adjusted odds ratio } \\
(95 \% \mathrm{CI})\end{array}$ \\
\hline Randomization & 1 direct test ordering & \\
\hline Group 2 & 2 watchful waiting & $2.25(1.09-4.60)$ \\
\hline Group 3 & $\begin{array}{l}3 \text { watchful waiting plus quality } \\
\text { improvement strategy }\end{array}$ & $1.12(0.64-1.97)$ \\
\hline Patient anxiety before the consultation & $\begin{array}{l}1 \text { above average } \\
2 \text { below average }\end{array}$ & $6.83(4.15-11.25)$ \\
\hline Patient expected referral to a specialist & $\begin{array}{l}1 \text { yes } \\
2 \text { no or don't care }\end{array}$ & $2.64(1.52-4.57)$ \\
\hline $\begin{array}{l}\text { Primary care physician felt certain that } \\
\text { there was no cause for alarm }\end{array}$ & $\begin{array}{l}1 \text { above median } \\
2 \text { below median }\end{array}$ & $2.37(1.02-5.51)$ \\
\hline $\begin{array}{l}\text { Primary care physician took a special } \\
\text { interest in psychiatry / psychosomatics / } \\
\text { unexplained complaints }\end{array}$ & $\begin{array}{l}1 \text { yes } \\
2 \text { no }\end{array}$ & $2.21(1.13-4.31)$ \\
\hline $\begin{array}{l}\text { Primary care physician performed physical } \\
\text { examination }\end{array}$ & $\begin{array}{l}1 \text { yes } \\
2 \text { no or unknown }\end{array}$ & $2.03(1.11-3.72)$ \\
\hline Patient expected blood tests to be ordered & $\begin{array}{l}1 \text { yes } \\
2 \text { no or unknown }\end{array}$ & $1.84(1.07-3.20)$ \\
\hline Patient considered complaints bearable & $\begin{array}{l}1 \text { bearable } \\
2 \text { unbearable }\end{array}$ & $0.56(0.32-0.97)$ \\
\hline Patient was satisfied with the consultation & $\begin{array}{l}1 \text { above average } \\
2 \text { below average }\end{array}$ & $0.53(0.32-0.88)$ \\
\hline Patient knew seriousness of complaints & $\begin{array}{l}1 \text { yes } \\
2 \text { no }\end{array}$ & $0.45(0.25-0.79)$ \\
\hline Intra cluster coeffic & & $2.53 e-7$ \\
\hline
\end{tabular}

\section{Conclusions}

This study did not confirm our hypothesis that a watchful waiting approach in test ordering for patients with unexplained complaints would decrease patient satisfaction and increase patient anxiety. The test ordering strategy appears not to influence either of these. Instead, specific aspects of physician-patient communication proved to be more important for patient satisfaction with the consultation and anxiety after the consultation.

The finding that satisfaction with the consultation was closely related to patients' satisfaction with their primary care physician in general, is in agreement with the literature on the concept of satisfaction ${ }^{27}$. The literature shows mixed results concerning the influence of the age of the primary care physicians on satisfaction ${ }^{29-31}$, with both lower and higher age reported to be related to patient satisfaction. Three other determinants of satisfaction, viz. patients feeling they were taken seriously, physicians discussing testing and patients knowing the seriousness of their complaints after the consultation, mainly concern 
communication aspects. It has been recognized before that these are important for patient satisfaction ${ }^{27,32}$. Primary care physicians tend to overestimate the bearableness of their patients' unexplained complaints, which might explain why some patients do not feel taken seriously. Although there is a tendency to view unexplained complaints of recent origin as mild and self-limiting, because patients frequently do not return to their primary care physicians for the complaints, this view may be incorrect, as longitudinal analyses from this trial show that such patients' quality of life tends to remain low, even after a year ${ }^{33,34}$. Patients with unexplained complaints frequently do not feel that they have been taken seriously, because they get the impression that physicians think they are faking their complaints ${ }^{35}$. It might be useful for primary care physicians in daily practice to discuss the bearableness of complaints with patients and to check whether patients feel that they know how serious their complaints are at the end of the consultation.

Though we did not find any evidence in the literature, it seems obvious to us that anxiety prior to the consultation influences anxiety afterwards. The negative influence of a physical examination on patient satisfaction is not so easy to explain. The usual advice for unexplained complaints is to do a physical examination to show that a patient is being taken seriously ${ }^{36}$. Proper evidence for this advice, however, is currently lacking. An alternative explanation is that primary care physicians recognize anxious patients and apply physical examination especially to this group, in order to reassure them, probably with limited effect. A third possible explanation is that patients usually do not expect to be examined and that, when they are, they view this as an alarm signal. However, the item in our questionnaire about patient expectations prior to the consultation did not yield a difference between patients who had expected physical examination and patients who had not.

As with satisfaction, the other determinants of anxiety were related to communication aspects. A patient's expectation that blood tests would be ordered, as well as their wish to be referred to a specialist, could be a signal to the primary care physician to explore anxiety. In addition, as with satisfaction, physicians' views about the alarming nature of the complaints do not always seem to correspond with those of their patients. The final determinant that was associated with higher levels of anxiety, namely whether the physician took a special interest in psychiatry, psychosomatics or unexplained complaints, was surprising to us. Our explanation for this finding is that physicians with such a special interest may tend to focus on the psychosocial factors in unexplained complaints. In the early stages of unexplained complaints, patients might then feel that insufficient attention is being given to the somatic aspects of the complaints. The literature shows that physicians' explanations are frequently at odds with the patients' own thinking ${ }^{37}$. Though patients are prepared to accept a psychosocial cause of their complaints, it is important to address their concerns, 
confirm the reality of their complaints and link physical and psychological factors $^{38-40}$. Exploring the bearableness of complaints, as well as the patients' feeling about the seriousness of their complaints and the nature of their concerns, may decrease their anxiety.

A strong feature of this study is that we used real consultations instead of hypothetical situations to assess patients' views about the consultation, and also included characteristics of the primary care physician and consultation in the analysis, as usually, only patients' opinions are taken into account. A limitation of the study was that selective inclusion of patients may have caused bias. The primary care physicians in group 2 (watchful waiting without quality improvement strategy) included fewer patients than those in the other groups. This seems to have been due to the number of primary care physicians in this group who did not include any patients in the study. If these physicians are left out of the analysis, no statistically significant difference in patient inclusion between the groups remains. Our explanation is that physicians hesitated to start asking patients to participate, because they did not have any extra diagnostic tests to offer them which could serve as a 'reward' for participation. If this were indeed the case, physicians in groups 2 and 3 should have included fewer patients. However, physicians in group 3 had participated in several training sessions in which they discussed the limited value of immediate test ordering and the effects of watchful waiting. Therefore, physicians in group 3 may have felt more confident about convincing patients to participate. Although we have no indications of selective inclusion, we cannot completely exclude it either. A non-inclusion analysis is hardly possible, since unexplained complaints are not registered as such in the patients' records by the physicians.

Our study showed that blood test ordering for patients with unexplained complaints is not related to the patients' satisfaction and anxiety, and thus that these patients do not differ much in this respect from a more general patient population ${ }^{20,32}$. This is especially remarkable as patients' satisfaction and anxiety are important factors in primary care physicians' decisions about test ordering. Apparently, primary care physicians overestimate the effects of additional testing in patients presenting with unexplained complaints and underestimate how much they themselves can contribute to the wellbeing of their patients by discussing their worries. 


\section{References}

1. Dinant $G J$, van Wijk MAM, Janssens HJEM, Somford RG, de Jager CJ, Beusmans GHMI, Dijkstra RH, Wiersma Tj. NHG-standaard bloedonderzoek. Algemene principes en uitvoering in eigen beheer. [Dutch College of General Practitioners guideline 'Blood testing. General principles and use by GP']. Huisarts Wet 1994;37:202-11.

2. Peveler $R$, Kilkenny $L$, Kinmonth $A-L$. Medically unexplained physical symptoms in primary care: A comparison of selfreport screening questionnaires and clinical opinion. J Psychosom Res 1997:42:245-52.

3. van der Weijden $T$, van Velsen $M$, Dinant GJ, van Hasselt CM, Grol RPTM. Unexplained complaints in general practice. Prevalence, patients' expectations, and professionals' testordering behavior. Med Decis Making 2003;23:226-31.

4. Burton C. Beyond somatisation: a review of the understanding and treatment of medically unexplained physical symptoms (MUPS). Br J Gen Pract 2003;53:231-41.

5. Feder $A$, Olfson $M$, Gameroff $M$, Fuentes $M$, Shea $S$, Lantigua RA, Weissman MM. Medically unexplained symptoms in an urban general medicine practice. Psychosomatics 2001;42: 261-8.

6. Koch $H$, van Bokhoven MA, ter Riet $G$, Hessels $K M$, van der Weijden $T$, Dinant GJ, Bindels PJE. What makes general practitioners order blood tests in patients with unexplained complaints: A cross-sectional study. submitted.

7. Hindmarsh JT, Lyon AW. Strategies to promote rational clinical chemistry test utilization. Clin Biochem 1996;29:291-9.

8. Winkens $R$, Dinant GJ. Evidence base of clinical diagnosis: Rational, cost effective use of investigations in clinical practice. BMJ 2002;324:783-5.

9. Solomon $\mathrm{DH}$, Hashimoto $H$, Daltroy L, Liang MH. Techniques to Improve Physicians' Use of Diagnostic Tests: A New Conceptual Framework. JAMA 1998;280:2020-7.

10. Little $P$, Gould $C$, Williamson I, Moore $M$, Warner $G$, Dunleavy J. Pragmatic randomised controlled trial of two prescribing strategies for childhood acute otitis media. BMJ 2001; 322:336-42.

11. Arroll $B$, Kenealy $T$, Kerse N. Do delayed prescriptions reduce antibiotic use in respiratory tract infections? A systematic review. Br J Gen Pract 2003;53:871-7.

12. de Vries SH, Raaijmakers R, Kranse R, Blijenberg BG, Schroder FH. Prostate cancer characteristics and prostate specific antigen changes in screening detected patients initially treated with a watchful waiting policy. The Journal of Urology 2004;172(6, Part 1):2193-6.

13. Hartley RM, Epstein AM, Harris CM, McNeil BJ. Differences in ambulatory test ordering in England and America. Role of doctors' beliefs and attitudes. Am J Med 1987;82:513-7.

14. van der Weijden T, van Bokhoven MA, Dinant GJ, van Hasselt CM, Grol RP. Understanding laboratory testing in diagnostic uncertainty: a qualitative study in general practice. $\mathrm{Br} J \mathrm{Gen}$ Pract 2002;52:974-80.

15. Prochazka AV, Lundahl K, Pearson W, Oboler SK, Anderson RJ. Support of evidence-based guidelines for the annual physical examination. A survey of primary care providers. Arch Intern Med 2005;165:1347-52.

16. Birbeck GL, Gifford DR, Song J, Belin TR, Mittman BS, Vickrey BG. Do malpractice concerns, payment mechanisms, and attitudes influence test-ordering decisions? . Neurology62:119-21.

17. Penchansky R, Macnee $C$. Initiation of medical malpractice suits: a conceptualization and test. Med Care 1994;32:813-31.

18. van Bokhoven MA, Pleunis-van Empel MCH, Koch H, Grol RPTM, Dinant GJ, van der Weijden T. Why do patients want to have their blood tested? A qualitative study of patient expectations. BMC Fam Pract 2006;7:75.

19. Kravitz RL, Bell RA, Azari R, Kelly-Reif S, Krupat E, Thom DH. Direct observation of requests for clinical services in office practice: What do patients want and do they get it? Arch Intern Med 2003; 163:1673-81. 
20. Peck BM, Ubel PA, Roter DL, Goold SD, Asch DA, Jeffreys AS, Grambow SC, Tulsky JA. Do unmet expectations for specific tests, referrals, and new medications reduce patients' satisfaction? J Gen Intern Med 2004;19:1080-7.

21. Jung HP, Wensing $M$, Grol R. What makes a good general practitioner: do patients and doctors have different views? Br J Gen Pract 1997;47:805-9.

22. Kravitz RL, Edward JC. Patients' perceptions of omitted examinations and tests. A qualitative analysis. J Gen Intern Med 2000;15:38-45.

23. Kravitz $R L$, Callahan EJ, Paterniti $D$, Antonius $D$, Dunham $M$, Lewis $C E$. Prevalence and Sources of Patients' Unmet Expectations for Care. Ann Intern Med 1996;125:730-7.

24. Stalenhoef JGA. Resultaten NIPO-enquête 2006: Wat vinden huisartsen en patiënten van elkaar? Huisarts Wet 2007;50:nhg 5.

25. Suchman ALMD, Roter DD, Green MD, Lipkin MJMD, The Collaborative Study Group of the American Academy on Physician and P. Physician Satisfaction With Primary Care Office Visits. Med Care 1993;31:1083-92.

26. Jackson J, Kincey J, Fiddler M, Creed F, Tomenson B. Differences between out-patients with physical disease and those with medically unexplained symptoms with respect to patient satisfaction, emotional distress and illness perception. $\mathrm{Br} J$ Health Psychol 2004:9(Pt 4): 433-46.

27. Sitzia J, Wood N. Patient satisfaction: a review of issues and concepts. Soc Sci Med 1997; 45:1829-43.

28. van Bokhoven MA, Koch $\mathrm{H}$, van der Weijden T, Bindels PJE, Grol RPTM, Dinant G-J. Blood test ordering for unexplained complaints in general practice, the VAMPIRE randomised clinical trial protocol. BMC Fam Pract 2006;7:20.

29. Garcia J, Paterniti D, Romano P, Kravitz R. Patient preferences for physician characteristics in university-based primary care clinics. Ethn Dis 2003;13:259-67.

30. Murphy-Cullen CL, Larsen LC. Interaction between the socio-demographic variables of physicians and their patients: Its impact upon patient satisfaction. Social Science \& Medicine 1984;19:163-6.

31. Kvamme O, Sandvik L, Hjortdahl P. Praksisform, legekarakteristika og pasientvurdert kvalitet $\mathrm{i}$ norsk allmennpraksis. Tidsskr Nor Laegeforen 2000;120:2499-502.

32. Thompson S, Nanni C, Schwankovsky L. Patient-oriented interventions to improve communication in a medical office visit. Health Psychol 1990;9:390-404.

33. Koch $H$, van Bokhoven MA, ter Riet $G$, van der Weijden $T$, Dinant $G J$, Bindels $P$. The course of unexplained complaints in general practice. J Psychosomatic Research 2006;61:419.

34. Kenter E, Okkes I, Oskam S, Lamberts H. Tiredness in Dutch family practice. Data on patients complaining of and/or diagnosed with 'tiredness'. Fam Pract 2003;20:434-40.

35. Hartz $A$, Noyes $R$, Bentler $S$, Damiano $P$, Willard J, Momany $E$. Unexplained symptoms in primary care: Perspectives of doctors and patients. Gen Hosp Psychiatry 2000;22:144-52.

36. van der Horst HE, Meijer JS, Muris JWM, Sprij B, Visser FMPB, Romeijnders ACM, Boukes FS. NHG-Standaard Prikkelbare Darm Syndroom (Irritable Bowel Syndrome). Huisarts Wet 2001:44:58-65.

37. Salmon P, Peters S, Stanley I. Patients' perceptions of medical explanations for somatisation disorders: qualitative analysis. BMJ 1999;318:372-6.

38. Dowrick CF, Ring A, Humphris GM, Salmon P. Normalisation of unexplained symptoms by general practitioners: a functional typology. Br J Gen Pract 2004;54:165-70.

39. Salmon $P$, Dowrick $C F$, Ring $A$, Humphris GM. Voiced but unheard agendas: qualitative analysis of the psychosocial cues that patients with unexplained symptoms present to general practitioners. Br J Gen Pract 2004;54:171-6.

40. Ring A, Dowrick C, Humphris G, Salmon P. Do patients with unexplained physical symptoms pressurise general practitioners for somatic treatment? A qualitative study. BMJ Clinical research ed. 2004;328:1057. 
$140 \mid$ Chapter 8

\section{APPENDIX 1}

Results of bivariate analysis of patient satisfaction with the consultation. Determinants that are significant at the $P<=0,1$ level are listed. The 'randomization' and 'lab testing' variables have been added.

Variable

Randomization

Lab testing

Primary care physician/practice characteristics

Age of primary care physician

Diagnostic facilities in the practice

Percentage of lab test orders per week

Special interest in musculoskeletal complaints

Special interest in psychiatry / psychosomatics unexplained complaints

Patient characteristics:

Highest level of education

Anxiety after the consultation

General satisfaction with primary care physician

Complaint/consultation characteristlcs

Primary care physician was certain there was no cause for alarm

Primary care physician was satisfied with the consultation

Complaints bearable according to primary care physician

In the estimation of primary care physician, the patient considered the complaints bearable Complaints bearable according to patient

Patient felt taken seriously

Primary care physician discussed additional testing with patient, according to patient

Primary care physician ordered blood tests, according to patient

Primary care physician had sufficient time for the patient, according to patient

Patlent wanted to be referred to a specialist

Patient knew serlousness of complaints after the consultation, according to patient

\section{Categories}

1 direct test ordering

2 watchful waiting

3 watchful waiting plus quality

improvement strategy

1 lab results received

2 no lab results received

$1 \leq 46$

$2 \geq 47$

1 above average

2 below average

1 above median

2 below median

1 yes

2 no

1 yes

2 no

Odds ratio $(90 \% \mathrm{Cl})$

$\chi^{2}$ test: 2.41

$1.25(0.92-1.70)$

$0.68(0.49-0.92)$

$1.59(1.17-2.16)$

$0.60(0.44-0.82)$

$0.47(0.22-0.99)$

$1.62(1.05-2.50)$

$0.71(0.52-0.96)$

$0.51(0.37-0.70)$

$15.49(10.18-23.56)$

2 below average

1 above average

2 below average

$0.44(0.26 \cdot 0.76)$

1 above median

2 below median

1 above average

2 below average

1 bearable

2 unbearable

1 bearable

2 unbearable

1 bearable

2 unbearable

1 at least sufficiently

2 insufficiently/somewhat/ unknown

1 yes

2 no or unknown

1 yes

2 no or unknown

1 good-excellent

2 insufficient-reasonably.

1 yes

2 no or don't care

1 yes

2 no
$1.56(1.13-2.16)$

$0.42(0.23-0.76)$

$0.64(0.44-0.94)$

$0.80(0.54-1.17)$

$15.75(5.82-42.59)$

$2.49(1.79-3.47)$

$1.47(1.07-2.02)$

$7.13(3.86-13.86)$

$0.60(0.43-0.84)$

$2.34(1.67-3.29)$ 


\section{APPENDIX 2}

Results of bivariate analysis of patient anxiety after the consultation. Determinants that are significant at the $p<=0.1$ level are listed. The 'randomization' and 'lab testing' variables have been added.

Variable

Randomization

Lab testing

Primary care physician/practice characteristics

Participated previously in continuing education on unexplained complaints

Special interest in psychiatry / psychosomatics / unexplained complaints

Patient characteristics

Highest level of education

Patient anxiety before the consultation

Quality of life (Euroqol thermometer)

General satisfaction with primary care physician

Complaint/ consultation characteristics

Primary care physician was certain that there was no cause for alarm

Patient satisfaction with the consultation

Duration of complaints

Patient considered complaints bearable

Accompanying symptoms

Primary care physician performed physical examination

Patient expected serious pathology

Patient expected blood testing

Patient expected other additional testing

Patient expected referral

Primary care physician had sufficient time for the patient, according to patient

Patient wanted to be referred to a speclalist

Patient knew seriousness of complaints after the consultation, according to patient

\section{Categories}

1 direct.

2 watchful waiting

3 watchful waiting plus quality

improvement strategy

1 lab results received

2 no lab results received

1 yes

2 no

1 yes

2 no

1 above average

2 below average

1 above average

2 below average

1 above average

2 below average

1 above average

2 below average

1 above median

2 below median

1 above average

2 below average

$1<1$ week

2 1-4 weeks

$3>4$ weeks

1 yes

2 no

1 yes

2 no/ unknown

1 yes

2 no/ unknown

1 yes

2 no/ unknown

1 yes

2 no/ unknown

1 yes

2 no/ unknown

1 yes

2 no/ unknown

1 good-excellent

2 insufficient- reasonably

1 yes

2 nol don't care

1 yes

2 no
Odds ratio $(90 \% \mathrm{Cl})$

$x^{2}$ test: 0.31

$1.17(0.86-1.59)$

$1.42(1.01-2.00)$

$1.66(1.08-2.55)$

$1.42(1.04-1.94)$

$7.82(5.51-11.10)$

$0.56(0.41-0.77)$

$0.52(0.38-0.72)$

$1.79(1.03-3.11)$

$0.51(0.37-0.70)$

$\chi^{2}$ test: 0.03

$0.49(0.35-0,69)$

$1.63(1.18-2.26)$

$1.66(1.14-2.42)$

$2.57(1.35-4.88)$

$1.55(1.11-2.17)$

$1,65(1.16 \times 2.36)$

$1.52(1.01-2.28)$

$0.49(0.31-0.77)$

$3.99(2.80-5.69)$

$0.42(0.29-0.60)$ 


\section{Chapter 9}

The costs of watchful waiting compared to immediate blood test ordering in patients with unexplained complaints in general practice, a randomised clinical trial [ISRCTN55755886]

MA. van Bokhoven, $H$ Koch, $T$ van der Weijden, A Ament, PJE Bindels, RPTM Grol, G-J Dinant

Submitted

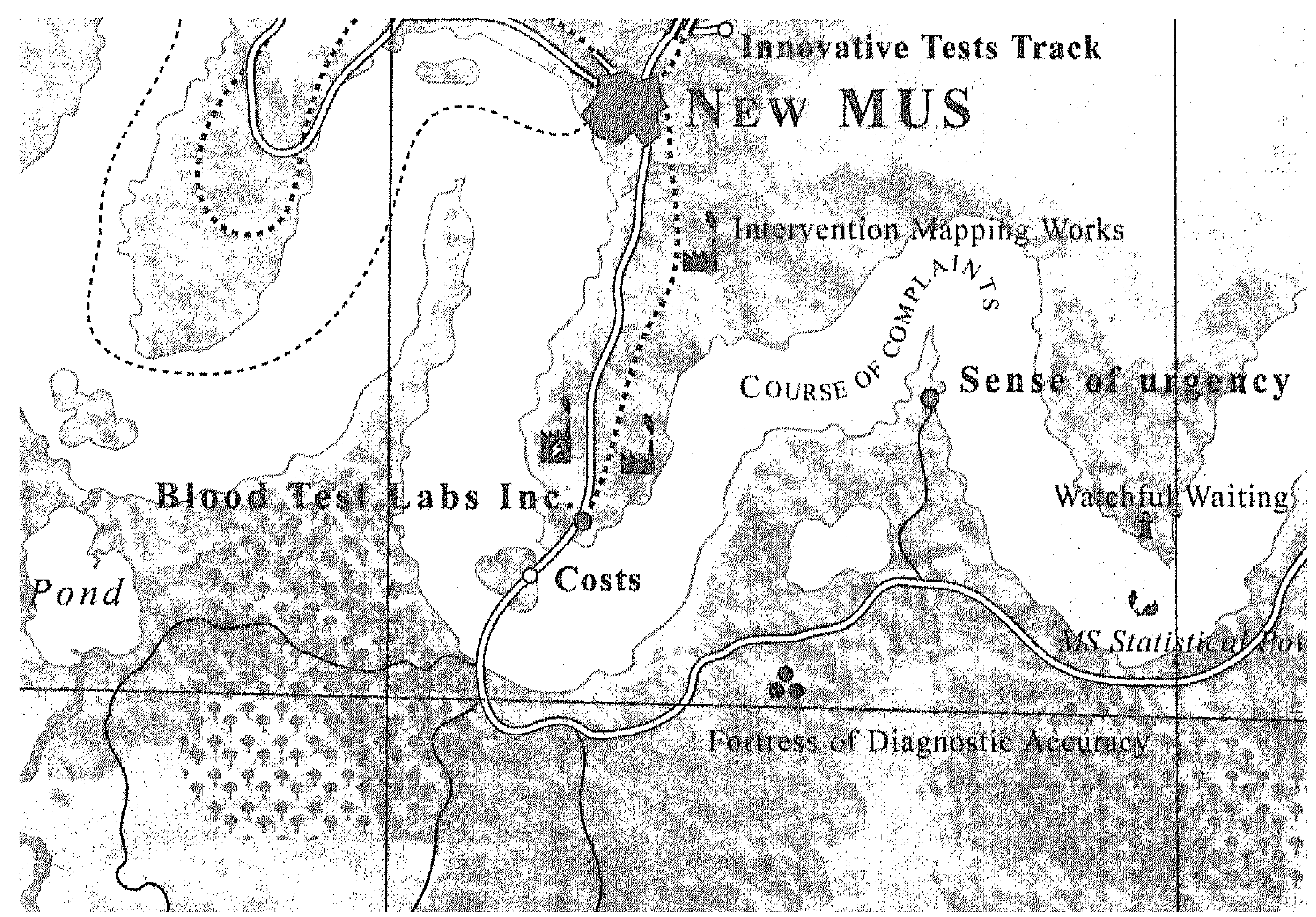


The costs of watchful waiting $\mid 145$

\section{Introduction}

Unexplained complaints are common in general practice. On average, $3-39 \%$ of all consultations involve complaints considered unexplained by the general practitioner $(\mathrm{GP})^{1-3}$. Unexplained complaints in general practice can be defined as 'those complaints for which a GP, after clarifying the reason for encounter, taking the patient's history and performing physical examination, is unable to establish a diagnosis ${ }^{4}$. Although GPs frequently order blood tests for these patients, the diagnostic accuracy of such tests is limited, due to the low prior chance of somatic pathology (estimated at $<5 \%$ ) in patients with unexplained complaints ${ }^{5,6}$. Because most complaints will be self-limiting, an approach involving 4 weeks of watchful waiting is expected to reduce both the number of patients to be tested and the number of patients who undergo unnecessary further diagnostic work-up following false-positive test results ${ }^{4,7}$. Such a policy is thus expected to reduce the costs of testing. However, it is not known whether watchful waiting and postponement of diagnostic test ordering does indeed reduce costs.

Many GPs perceive barriers to postponement of test ordering. They mention that patients request tests, that it is difficult to reassure their patients without testing and that they use tests as a substitute when patients request more expensive diagnostics or hospital referrals ${ }^{8,9}$.

One might also argue that postponement of blood test ordering could lead to higher costs, due to substitution of care, as patients may seek reassurance by consulting complementary therapists or purchase of over-the-counter (OTC) medication, or as GPs may resort to more expensive tests or referrals.

The objective of this study was to compare the costs of care in a watchful waiting approach with the costs of immediate blood test ordering. We wanted to answer the following questions: (1) What are the differences in costs of blood test ordering between immediate test ordering and watchful waiting? (2) Do patients in the watchful waiting group seek substitution of care through complementary medicine or OTC medication? (3) Do the GPs in the watchful waiting group deliver different care as a substitute for test ordering? (4) Do the total direct costs of care during a one year follow-up period differ between the two test ordering approaches.

\section{Methods}

In this study we analysed the health care sector costs relating to the possible consequences of the two test ordering approaches, using a health care perspective ${ }^{10}$. 
The study was part of a cluster-randomised clinical trial with GPs' practices as the level of randomisation, in which watchful waiting was compared with immediate blood test ordering. The full protocol of this trial has been published elsewhere ${ }^{11}$. Practices were randomised using a random number seed computer program that randomised in blocks. Group 1 was instructed to order blood tests immediately (ITO group) and group 2 to postpone testing by applying a watchful waiting approach (WW group). The medical ethics review boards of both the Academic Medical Center-University of Amsterdam and the University Hospital Maastricht approved the study.

\section{Participants}

GPS

For logistic reasons, regional laboratories in the western and southern parts of the Netherlands were first asked to participate in the trial. Subsequently, all GPs who use the participating laboratories to handle their test orders were asked to participate.

\section{Patients}

The GPs were asked to enrol each consecutive eligible patient. Patients aged 18 years and older were eligible if they presented with one of the following complaints: fatigue, abdominal complaints, weight changes, musculoskeletal complaints or itch. Their complaints had to be unexplained according to the definition given in the introduction. Patients also had to be able to read, speak and understand Dutch. Excluded were patients with unexplained complaints that caused a sense of alarm in the GP, making watchful waiting unacceptable. Patients were presented with written information about the study and they were asked to give informed consent. The GPs instructed the patients to return if the complaints had not disappeared in four weeks.

\section{Measurements}

The measurement instruments have been summarised in Table 9.1.

When GPs ordered blood tests, a standard set of tests was done. In addition, GPs could state if they would have liked to order tests themselves, and if so, which tests they would have ordered.

We received a copy of the laboratory test results form, which we used to collect the blood test ordering data. Data about medication prescriptions and about additional diagnostic tests other than blood tests were collected from the patients' medical records. Record data were collected retrospectively over the year following the day of a patient's inclusion. Two authors (MB and HK) 
independently extracted the data and recorded them on a structured form. Afterwards they discussed discrepancies. If they did not reach consensus immediately, two experienced members (GD and $P B$ ) of the research team, both GPs, made the final decision. Data about follow-up contacts with the GPs, referrals to hospital specialists and psychosocial care, use of complementary medicine, physiotherapy and OTC medication were derived from the patient questionnaires. All patients received such a questionnaire, with questions about health care consumption in the past four weeks. The questionnaire was handed out to them by the GPs when they returned with complaints that still persisted after the initial consultation, together with a stamped envelope that allowed them to return the questionnaire to the research team immediately after filling it in at home. Patients who did not re-consult within six weeks received a questionnaire and a stamped envelope by mail. Finally, all patients received questionnaires and stamped envelopes at six and twelve months.

Table $9.1 \quad$ Instruments and variables.

\begin{tabular}{|c|c|c|c|c|c|c|c|}
\hline \multirow[t]{2}{*}{ Instrument } & \multirow[t]{2}{*}{ Variables } & \multicolumn{5}{|c|}{ Time points (in moths) } & \multirow{2}{*}{$\begin{array}{l}\text { Method } \\
\text { - Provision } \\
\text { - Person who } \\
\text { completes } \\
\text { questionnaire }\end{array}$} \\
\hline & & TO & $\mathrm{T} 1^{\mathrm{b}}$ & $T 1.5^{b}$ & T6 & $\mathrm{T} 12$ & \\
\hline $\begin{array}{l}\text { GPs' background } \\
\text { data }\end{array}$ & Personal data & $x$ & & & & & $\begin{array}{l}\text { - By mail } \\
\text { - GP }\end{array}$ \\
\hline \multirow{6}{*}{$\begin{array}{l}\text { Patients' } \\
\text { background data } \\
\text { (included in patient } \\
\text { questionnaire) }\end{array}$} & Date of birth & $x$ & $x$ & $x$ & $\mathbf{x}$ & $x$ & \multirow{6}{*}{$\begin{array}{l}\text { - Handed out by GP } \\
\text { (TO, T1) } \\
\text { - By mail (T1.5-T12) } \\
\text { - Patient }\end{array}$} \\
\hline & Country of birth & $x$ & $x$ & $x$ & $x$ & $\mathrm{x}$ & \\
\hline & Sex & $x$ & $x$ & $x$ & $x$ & $\mathrm{x}$ & \\
\hline & Marital status & $x$ & $x$ & $x$ & $x$ & $x$ & \\
\hline & Type of health insurance & $\mathrm{x}$ & $x$ & $x$ & $x$ & $\mathrm{x}$ & \\
\hline & Level of education & $x$ & $x$ & $x$ & $\mathrm{x}$ & $x$ & \\
\hline $\begin{array}{l}\text { Patient } \\
\text { questionnaire }\end{array}$ & Utilisation of health care & $x$ & $x$ & $x$ & $x$ & $x$ & $\begin{array}{l}\text { - Handed out by GP } \\
\text { (T0, T1) } \\
\text { - By mail (T1.5-T12) } \\
\text { - Patient }\end{array}$ \\
\hline Test result form & Tests ordered & $x^{a}$ & $x^{a}$ & & & & $\begin{array}{l}\text { - Laboratory } \\
\text { - Laboratory staff }\end{array}$ \\
\hline Patient record & Utilisation of health care & & & & & $x$ & $\begin{array}{l}\text { - Practice/university } \\
\text { - Researcher }\end{array}$ \\
\hline
\end{tabular}

${ }^{\mathrm{a}}$ T1 only for patients who revisited their GP; ${ }^{\mathrm{b}} \mathrm{T} 1$ is the follow-up visit by the patient four weeks after inclusion. If a patient did not return to the GP, a questionnaire was sent to them by mail after six
weeks. This time point is indicated as T1.5. 
$148 \mid$ Chapter 9

\section{Statistical analysis}

For each type of care, we counted the numbers of patients who received it either at the first consultation or during follow-up. We also assessed whether patients had been tested after approximately four weeks.

Costs of the use of OTC medication and medication prescriptions were analysed by directly computing the mean amount spent per patient per group. For all other cost categories, we multiplied the volumes per patient by the cost price, which was derived from national guidelines on cost research in health care $^{12}$. When GPs indicated that they would have ordered tests themselves, we analysed the number of tests they would have ordered per consultation. Practical limitations meant that we could only analyse this for the first year of patient inclusion. We used this number to calculate the mean costs of tests ordered per patient. For medication prescribed by the GPS, we determined the mean costs per patient in a sample of patients, using a national reference book about all available medications ${ }^{13}$. Since there are no standards for the costs of complementary medicine, we estimated the cost price from information provided by a health care insurance company and the Dutch association for homeopathy physicians. We computed means and medians per group plus inter-quartile range, both per cost category and overall. For each cost category mean numbers per person, per group were compared using Mann-Whitney $U$ tests. Subsequently, for each cost category mean costs per person, per group were compared using independent samples t-tests. An 'intention-to-test' analysis was done.

\section{Results}

Inclusion took place from February 2002 until December 2003. In total, 62 primary care physicians were randomised in the study, seven of whom ended their participation before the inclusion started, mainly due to private circumstances and a busy practice schedule, while 14 did not include any patients. In the end, 41 primary care physicians included 330 patients, 232 in the ITO group and 98 in the WW group (Figure 9.1). Background characteristics of both primary care physicians and patients are summarised in Tables 9.2 and 9.3. Of the $41 \mathrm{GPs}$ who included patients, 27 were in the ITO group (22 practices) and 14 in the WW group (14). The mean age of the participating GPs was 45 years (SD 6.6), and $69 \%$ were male. They had a mean of 13 years of experience (SD 7.9). The mean age of the patients was 44 years (SD 15.5, $95 \% \mathrm{Cl}-6.75-0.88)$ and $27 \%$ were male ( $95 \% \mathrm{Cl} 0.99-3.13)$. 


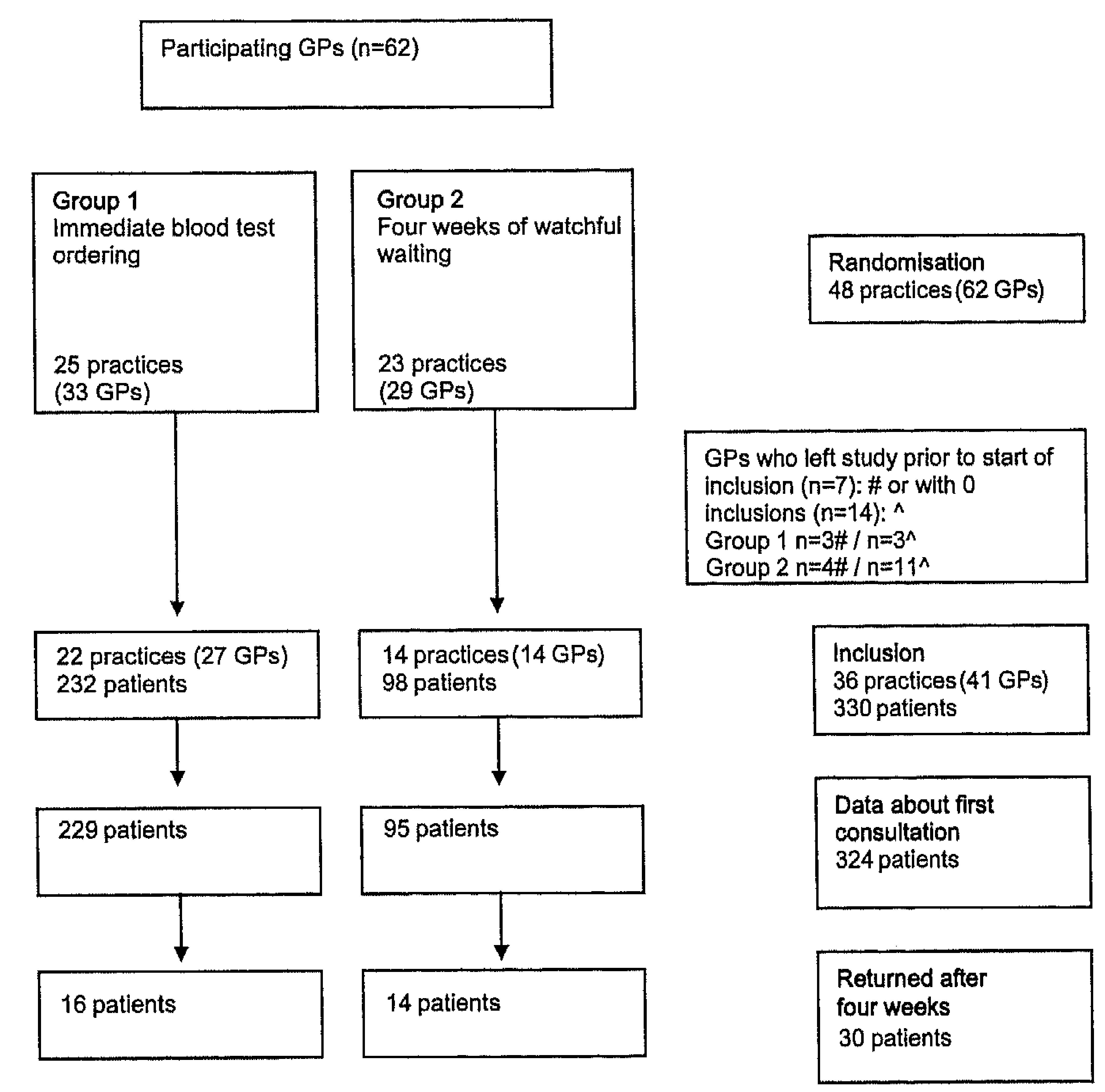

Figure 9.1 Participant flow.

Table 9.2 Background data of participating GPs.

\begin{tabular}{|c|c|c|c|c|}
\hline \multirow[t]{2}{*}{ Variables } & \multirow[t]{2}{*}{ Categories } & \multirow{2}{*}{$\begin{array}{l}\text { Results overall } \\
\quad(n=62)\end{array}$} & \multicolumn{2}{|c|}{ Randomisation } \\
\hline & & & $\begin{array}{c}\text { Group } 1 \\
\text { (Immediate testing) } \\
(n=33)\end{array}$ & $\begin{array}{c}\text { Group } 2 \\
\text { (Watchful waiting) } \\
(n=29)\end{array}$ \\
\hline Mean age years (SD) & & $45(6.6)$ & $47(5.8)$ & $44(7.2)$ \\
\hline $\operatorname{Sex} n(\%)$ & Male & $43(69)$ & $26(79)$ & $17(59)$ \\
\hline $\begin{array}{l}\text { Mean number of years of } \\
\text { experience as a GP (SD) }\end{array}$ & & $13(7.9)$ & $14(7.1)$ & $11(8.4)$ \\
\hline $\begin{array}{l}\text { Organisation of practices } \\
\text { (soloists versus other) } n(\%)\end{array}$ & Solo & $24(39)$ & $9(27)$ & $15(52)$ \\
\hline Practice location n (\%) & $\begin{array}{l}\text { Urban } \\
\text { Semi-rural } \\
\text { Rural }\end{array}$ & $\begin{array}{r}30(49) \\
9(15) \\
22(36)\end{array}$ & $\begin{array}{r}15(47) \\
4(13) \\
13(41)\end{array}$ & $\begin{array}{r}15(52) \\
5(17) \\
9(31)\end{array}$ \\
\hline
\end{tabular}


$150 \mid$ Chapter 9

Table 9.3 Background variables of participating patients.

\begin{tabular}{|c|c|c|c|c|c|}
\hline \multirow[t]{2}{*}{ Variables } & \multirow[t]{2}{*}{ Categories } & \multirow{2}{*}{$\begin{array}{l}\text { Results } \\
\text { overall } \\
(n=330)\end{array}$} & \multicolumn{2}{|c|}{ Randomisation } & \multirow{2}{*}{$\begin{array}{l}\text { Significanc } \\
\text { t-test or } \chi^{2} \\
\text { when } \\
\text { applicable }\end{array}$} \\
\hline & & & $\begin{array}{c}\text { Group } 1 \\
\text { (Immediatete } \\
\text { sting) } \\
(n=232)\end{array}$ & $\begin{array}{c}\text { Group } 2 \\
\text { (Watchful } \\
\text { waiting) } \\
(n=98)\end{array}$ & \\
\hline Mean age in years (SD) & & $44(15.5)$ & $43(15.5)$ & $46(15.5)$ & $P=0.13$ \\
\hline $\operatorname{Sex}(\%)$ & Male & $88(26.7)$ & $69(29.7)$ & $19(19.4)$ & $P=0.05$ \\
\hline $\begin{array}{l}\text { Type of health insurance: } \\
\text { private versus compulsory } \\
\text { state health insurance (\%) }\end{array}$ & Private & $117(37.1)$ & $80(35.9)$ & $37(40.2)$ & $P=0.47$ \\
\hline \multirow{4}{*}{ Highest level of education (\% } & $\begin{array}{l}\text { None } \\
\text { completed }\end{array}$ & $3(1.0)$ & $2(0.9)$ & $1(1.1)$ & n.a. ${ }^{a}$ \\
\hline & Elementary & $22(7.1)$ & $19(8.7)$ & $3(3,3)$ & \\
\hline & Secondary & $\begin{array}{r}209(67.9) \\
74(24.0)\end{array}$ & $144(66.1)$ & 65 (62.2) & \\
\hline & Higher & & $53(24.3)$ & $21(23.3)$ & \\
\hline
\end{tabular}

\section{Costs of testing}

In the ITO group, 211 (90.9\%) patients were tested immediately and two were tested again when they returned. The corresponding figures for the WW group were $14(14.3 \%)$ and 3 , respectively. If GPs would have ordered tests themselves at the initial consultation, the average number of tests was seven per patient in both groups. GPs in the ITO group spent an average of $€ 15.92$ and those in the WW group $€ 3.04$ per patient on blood tests (Table 9.4).

Table 9.4 Differences in costs of blood test ordering between an immediate test ordering approach and a watchful waiting approach.

Group 1 (immediate test ordering)

$$
n=232
$$

Number of Mean costs patients (\%)

Mean costs/
patient in Euro

First consultation After watchful waiting

Total

$\begin{array}{cc}211(90.9) & 15.92 \\ 2(0.9) & 0.16 \\ & 16.08\end{array}$

Group 2 (watchful waiting) $n=98$

Number of Mean costs/ patients (\%) patient in Euro

$14(14.3)$

2.50

$3(3.1)$

0.54

3.04 


\section{Substitution of testing by the patient}

Nine patients in the ITO group (3.9\%) and 5 in the WW group (5.1\%) visited a complementary therapist $(P=0.62)$. Eighty patients $(34.5 \%)$ in the ITO group and $37(37.8 \%)$ in the WW group purchased OTC medication (Table 9.5$)$.

\begin{tabular}{|c|c|c|c|c|c|}
\hline Table 9.5 & $\begin{array}{l}\text { erences in use } \\
\text { ents between } \\
\text { roach, after the }\end{array}$ & $\begin{array}{l}\text { omplementary } \\
\text { immediate test } \\
\text { t consultation. }\end{array}$ & $\begin{array}{l}\text { nedicine and } \\
\text { ordering ap }\end{array}$ & $\begin{array}{l}\text { purchase of OT } \\
\text { pproach and a }\end{array}$ & $\begin{array}{l}\text { C medication by } \\
\text { watchful waiting }\end{array}$ \\
\hline \multirow[t]{2}{*}{ Type of care } & \multicolumn{2}{|c|}{$\begin{array}{l}\text { Group } 1 \text { (immediate test ordering) } \\
\qquad n=232\end{array}$} & \multicolumn{2}{|c|}{$\begin{array}{l}\text { Group } 2 \text { (watchful waiting) } \\
\qquad n=98\end{array}$} & \multirow[t]{2}{*}{ Mann-Whitney } \\
\hline & $\begin{array}{l}\text { Number of } \\
\text { patients }(\%)\end{array}$ & $\begin{array}{l}\text { Mean number/ } \\
\text { patient }\end{array}$ & $\begin{array}{l}\text { Number of } \\
\text { patients }(\%)\end{array}$ & $\begin{array}{l}\text { Mean number/ } \\
\text { patient }\end{array}$ & \\
\hline $\begin{array}{l}\text { Visits to } \\
\text { complementary } \\
\text { therapist }\end{array}$ & $9(3.9)$ & 0.07 & $5(5.1)$ & 0.09 & $P=0.62$ \\
\hline $\begin{array}{l}\text { Purchase of OTC } \\
\text { medication }^{2}\end{array}$ & $80(34.5)$ & - & $37(37.8)$ & - & -- \\
\hline
\end{tabular}

\section{Substitution of testing by the GP}

Volumes of types of care that could serve as a substitute for blood test ordering have been summarised in Table 9.6. None of these were different between both groups in a statistically significant way.

\section{Overall direct costs of health care}

Data for the different types of costs have been summarised in Table 9.7. None of the cost categories were statistically significantly different between the groups. Total mean costs per patient in the ITO group were $€ 215.83$ and those in the $W W$ group $€ 151.34(P=0.24)$. 
$152 \mid$ Chapter 9

Table 9.6 Differences in care at first consultation by GPs between an immediate test ordering approach and a watchful waiting approach.

Type of care Group 1 (immediate test ordering) Group 2 (watchful waiting) Mann-Whitney

$$
n=232 \quad n=98
$$

Number of Mean numberl Number of Mean numberl patients $(\%)$ patient patients (\%) patient

\begin{tabular}{|c|c|c|c|c|c|}
\hline $\begin{array}{l}\text { Laboratory testing } \\
\text { in GP's own } \\
\text { practice }^{\text {a }}\end{array}$ & $9(3.9)$ & - & $3(3.1)$ & $-\cdots$ & $-\infty$ \\
\hline $\begin{array}{l}\text { Radiology } \\
\text { procedures }\end{array}$ & $7(3)$ & 0.03 & $4(4.1)$ & 0.04 & $P=0.63$ \\
\hline $\begin{array}{l}\text { Microbiology } \\
\text { procedures }\end{array}$ & $3(1.3)$ & 0.11 & $0(0)$ & 0 & $P=0.26$ \\
\hline ECG/spirometry & $7(3)$ & 0.23 & $0(0)$ & 0 & $P=0.08$ \\
\hline Prescriptions ${ }^{a}$ & $51(23.6)$ & - & $7(8.0)$ & - & - \\
\hline $\begin{array}{l}\text { Physiotherapy } \\
\text { sessions }\end{array}$ & $30(12.9)$ & 0.47 & $14(14.3)$ & 0.66 & $P=0.74$ \\
\hline $\begin{array}{l}\text { Psychosocial care } \\
\text { visits }\end{array}$ & $6(2.6)$ & 0.05 & $1(1.0)$ & 0.01 & $P=0.37$ \\
\hline $\begin{array}{l}\text { Hospital specialist } \\
\text { visits }\end{array}$ & $19(8.2)$ & 0.13 & $8(8.2)$ & 0.19 & $P=0.99$ \\
\hline
\end{tabular}

Table 9.7 Differences in total health care sector costs between an immediate test ordering approach and a watchful waiting approach, during a one year follow-up period.

Cost category

Costs, median (interquartile range), mean

t-test

GP practice visits Home calls by GP

Blood tests

Radiology

Microbiology

ECG/spirometry

Prescriptions

Physiotherapy

Psychosocial care

Hospital specialist referrals

Hospital admission

Complementary medicine

OTC medication

Goup 1 (immediate test ordering) Group 2 (watchful waiting)

Total

$\begin{array}{crcrc}20.20(20.20-40.40) & 34.74 & 20.20(20.20-40.40) & 31.74 & 0.35 \\ 0.00(0.00-0.00) & 0.35 & 0.00(0.00-0.00) & 0.82 & 0.47 \\ 17.50(17.50-17.50) & 16.08 & 0.00(0.00-0.00) & 3.04<0.001 \\ 0.00(0.00-0.00) & 4.14 & 0.00(0.00-0.00) & 4.08 & 0.97 \\ 0.00(0.00-0.00) & 0.16 & 0.00(0.00-0.00) & 0.09 & 0.50 \\ 0.00(0.00-0.00) & 1.72 & 0.00(0.00-0.00) & 0.00 & 0.08 \\ 0.00(0.00-0.00) & 1.62 & 0.00(0.00-0.00) & 0.77 & 0.22 \\ 0.00(0.00-0.00) & 32.52 & 0.00(0.00-0.00) & 28.40 & 0.70 \\ 0.00(0.00-0.00) & 44.90 & 0.00(0.00-0.00) & 16.45 & 0.26 \\ 0.00(0.00-0.00) & 30.17 & 0.00(0.00-0.00) & 30.29 & 0.99 \\ 0.00(0.00-0.00) & 26.15 & 0.00(0.00-0.00) & 3.44 & 0.42 \\ 0.00(0.00-0.00) & 8.02 & 0.00(0.00-0.00) & 16.53 & 0.29 \\ 0.00(0.00-9.77) & 15.29 & 0.00(0.00-11.88) & 15.70 & 0.94 \\ 77.70(37.70-174.40) 215.83 & 60.20(20.20-195.08) 151.34 & 0.24\end{array}$

$P<0.05$ 


\section{Discussion}

We found that a watchful waiting approach does indeed reduce blood test ordering, resulting in a saving of $€ 13.04$ in tests per patient. In contrast to the GPs' perception, patients who are not tested immediately do not seek reassurance by using self-management. Furthermore, immediate test ordering does not appear to be a substitute for more expensive diagnostics or referrals. The total direct health care costs of a watchful waiting approach are lower than those of an immediate test ordering approach. The lower costs in the watchful waiting group are not only determined by differences in costs of tests ordering but also in other costs. Although the difference is not statistically significant, the tendency of additional diagnostic procedures and treatments are all in the same direction.

The $€ 64.49$ difference in costs between both groups is limited in an absolute sense, but if all GPs would test immediately, the impact on health care costs is considerable, because the prevalence of unexplained complaints in general practice is up to $39 \%^{1-3}$. An explanation for the higher health care costs in the ITO-group may be that immediate test ordering causes a cascade of further testing and treatments. This cascade may be induced by false-positive test results. The risk of false-positive test results is relatively high among patients with unexplained complaints, because the prevalence of serious pathology in this group is low. However, we did not evaluate this further and the evidence that such a cascade exists is limited, though it has a sound theoretical base in Bayes' theorem ${ }^{14,15}$.

The conclusions should be interpreted with some caution, as they most probably underestimate the true costs. The first reason is that data from the patient questionnaires were recorded for three one-month periods instead of all twelve moths of follow-up. We chose this method because patients do not always recall correctly when they have to report over longer periods of time ${ }^{16}$. However, this underestimation does not change the magnitude of the difference between the two test ordering approaches. The second reason is that costs outside care, such as absence from work, were not taken into account.

Another possible limitation of the study was that selective inclusion of patients may have caused bias. The primary care physicians in the WW-group included fewer patients than those in the ITO-group. This appears to have been due to those primary care physicians in this group who did not include any patients in the study. If these physicians are omitted from the analysis, no statistically significant difference in patient inclusion remains between the groups. A possible explanation is that physicians in the WW-group may have hesitated to start asking patients to participate, because they did not have any extra diagnostic tests to offer them which could serve as a 'reward' for participation. Although we have no indications of selective inclusion, we cannot completely 
exclude it either. A non-inclusion analysis is hardly possible, since unexplained complaints are not recorded as such by the physicians in the patient records.

Although the cost data in our study have a skewed distribution, we chose to use a parametrical method (t-test) to determine statistical significance. We agree with the arguments of Thompson and Barber that only the arithmetic mean provides meaningful information about costs as the basis for health care policy decisions and that transformations or non-parametric methods may provide misleading results ${ }^{17}$.

In this study, we chose to analyse only the health care sector costs relating to the possible consequences of the two test ordering approaches because it is unlikely that these test ordering approaches lead to differences in clinical outcome. Although this is theoretically sound, there is no empirical evidence to support this view.

With respect to the costs of blood test ordering, our findings seem to be in line with those from research on watchful waiting in antibiotics prescriptions, which show a cost reduction ${ }^{18}$. The results of the antibiotics study were sensitive to the frequency with which patients returned for follow-up: the lower the return frequency, the more favourable the watchful waiting approach. We expect the same in our study, as costs of consultations are somewhat higher than those of blood test orders. When we compare the costs in our population with the health care consumption in an average general practice population or in an open population, the costs in our population were never higher than these costs. The studies on these reference populations included consumption for all complaints over one year. The comparison shows that unexplained complaints of recent origin in general practice do not lead to excessive health care consumption ${ }^{19,20}$. Our study took no account of the non-financial results of the test ordering approaches, like the patients' quality of life and satisfaction with care, or GPs' consultation efficiency. It is known, however, that GPs' perception of these two aspects contributes to their actual blood test ordering behaviour ${ }^{9}$. We have previously concluded from research into patient satisfaction that it is not influenced by the test ordering approach ${ }^{21}$. No information is available on differences between the test ordering approaches regarding 'diagnostic value', quality of life or the GPs' sense of efficiency.

In conclusion, the assumption that a watchful waiting approach leads to lower costs of care appears to be confirmed. In addition, we could not confirm the GPs' assumption that immediate test ordering is a substitute for more expensive diagnostic procedures, referrals or self-management. Thus, from a financial point of view, watchful waiting is superior to immediate test ordering. However, the choice between the two approaches may also need to take into account non-financial arguments such as reassurance, satisfaction and efficiency, though more knowledge about their influences in test ordering is needed. 
The costs of watchful waiting $\mid 155$

\section{References}

1. van der Weijden $T$, van Velsen $M$, Dinant $G J$, van Hasselt $C M$, Grol RPTM. Unexplained complaints in general practice. Prevalence, patients' expectations, and professionals' testordering behavior. Med Decis Making 2003;23:226-31.

2. Burton C. Beyond somatisation: a review of the understanding and treatment of medically unexplained physical symptoms (MUPS). Br J Gen Pract. 2003;53:231-41.

3. Peveler R, Kilkenny $L$, Kinmonth $A-L$. Medically unexplained physical symptoms in primary care: A comparison of selfreport screening questionnaires and clinical opinion. J Psychosom Res 1997;42:245-52.

4. Dinant GJ, van Wijk MAM, Janssens HJEM, Somford RG, de Jager CJ, Beusmans GHMI, Dijkstra RH, Wiersma Tj. NHG-standaard bloedonderzoek. Algemene principes en uitvoering in eigen beheer. [Dutch College of General Practitioners guideline 'Blood testing. General principles and use by GP']. Huisarts Wet 1994;37:202-11.

5. Koch $H$, van Bokhoven MA, ter Riet $G$, Hessels $K$, Van der Weijden T, Dinant GJ, Bindels PJE. What makes general practitioners order blood tests in patients with unexplained complaints: A cross-sectional study. submitted.

6. Feder $A$, Olfson $M$, Gameroff $M$, Fuentes $M$, Shea $S$, Lantigua RA, Weissman MM. Medically Unexplained Symptoms in an Urban General Medicine Practice. Psychosomatics 2001;42: 261-8.

7. Kenter E, Okkes I, Oskam S, Lamberts H. Tiredness in Dutch family practice. Data on patients complaining of and/or diagnosed with 'tiredness'. Fam Pract 2003;20:434-40.

8. Hartley RM, Epstein AM, Harris CM, McNeil BJ. Differences in ambulatory test ordering in England and America. Role of doctors' beliefs and attitudes. Am J Med 1987;82:513-7.

9. van der Weijden T, van Bokhoven MA, Dinant GJ, van Hasselt CM, Grol RPTM. Understanding laboratory testing in diagnostic uncertainty: a qualitative study in general practice. Br J Gen Pract 2002;52:974-80.

10. Drummond MF. Methods for the economic evaluation of health care programmes. Oxford: Oxford University Press; 2005.

11. van Bokhoven MA, Koch $H_{1}$ van der Weijden T, Bindels PJE, Grol RPTM, Dinant GJ. Blood test ordering for unexplained complaints in general practice, the VAMPIRE randomised clinical trial protocol. [ISRCTN55755886]. BMC Fam Pract 2006;7:20.

12. Oostenbrink JB, Bouwmans CAM, Koopmanschap MA, Rutten FFH. Handleiding voor kostenonderzoek. Methoden en standaard kostprijzen voor economische evaluaties in de gezondheidszorg. Amstelveen: College voor zorgverzekeringen; geactualiseerde versie 2004.

13. van Loenen $A C$, editor. Farmacotherapeutisch Kompas: medisch farmaceutische voorlichting. Amstelveen: Commissie Farmaceutische Hulp van het college voor zorgverzekeringen; 2004.

14. Vafiadis $P$. The dilemma of the unexpected result. Aust Fam Physician 1996;25:971-3.

15. Sherwood P, Lyburn I, Brown S, Ryder $S$. How are abnormal results for liver function tests dealt with in primary care? Audit of yield and impact. BMJ 2001;322:276-8.

16. van der Meer JBW, van den Bos J, Looman CWN, Mackenbach JP. Een zorg minder? De longitudinale studie naar sociaal-economische verschillen in medische consumptie (LSSEVM). Rotterdam: Instituut maatschappelijke gezondheidszorg, Erasmus universiteit Rotterdam; 1996.

17. Thompson SG, Barber JA. How should cost data in pragmatic randomised trials be analysed? BMJ 2000;320:1197-200.

18. Coco AS. Cost-Effectiveness Analysis of Treatment Options for Acute Otitis Media. Ann Fam Med 2007;5:29-38.

19. van Lindert $H_{1}$ Droomers $M$, Westert GP. Tweede Nationale Studie naar ziekten en verrichtingen in de huisartspraktijk. Een kwestie van verschil: verschillen in zelfgerapporteerde leefstijl, gezondheid en zorggebruik. Utrecht/Bilthoven: NIVEL/RIVM; 2004.

20. Statistics Netherlands (CBS). Health and Welfare figures. 
156 Chapter 9

21. van Bokhoven MA, Koch $H$, van der Weijden T, Grol RPTM, Kester AD, Rinkens PELM, Bindels PJE, Dinant GJ. The influence of a watchful waiting approach on satisfaction and anxiety among patients presenting with unexplained complaints in family practice. submitted. 


\section{Chapter 10}

Exploring the black box of change in improving test ordering routines

MA van Bokhoven, $H$ Koch, GJ Dinant, PJE Bindels, RPTM Grol,

$T$ van der Weijden

Fam Pract 2008:25:139-145

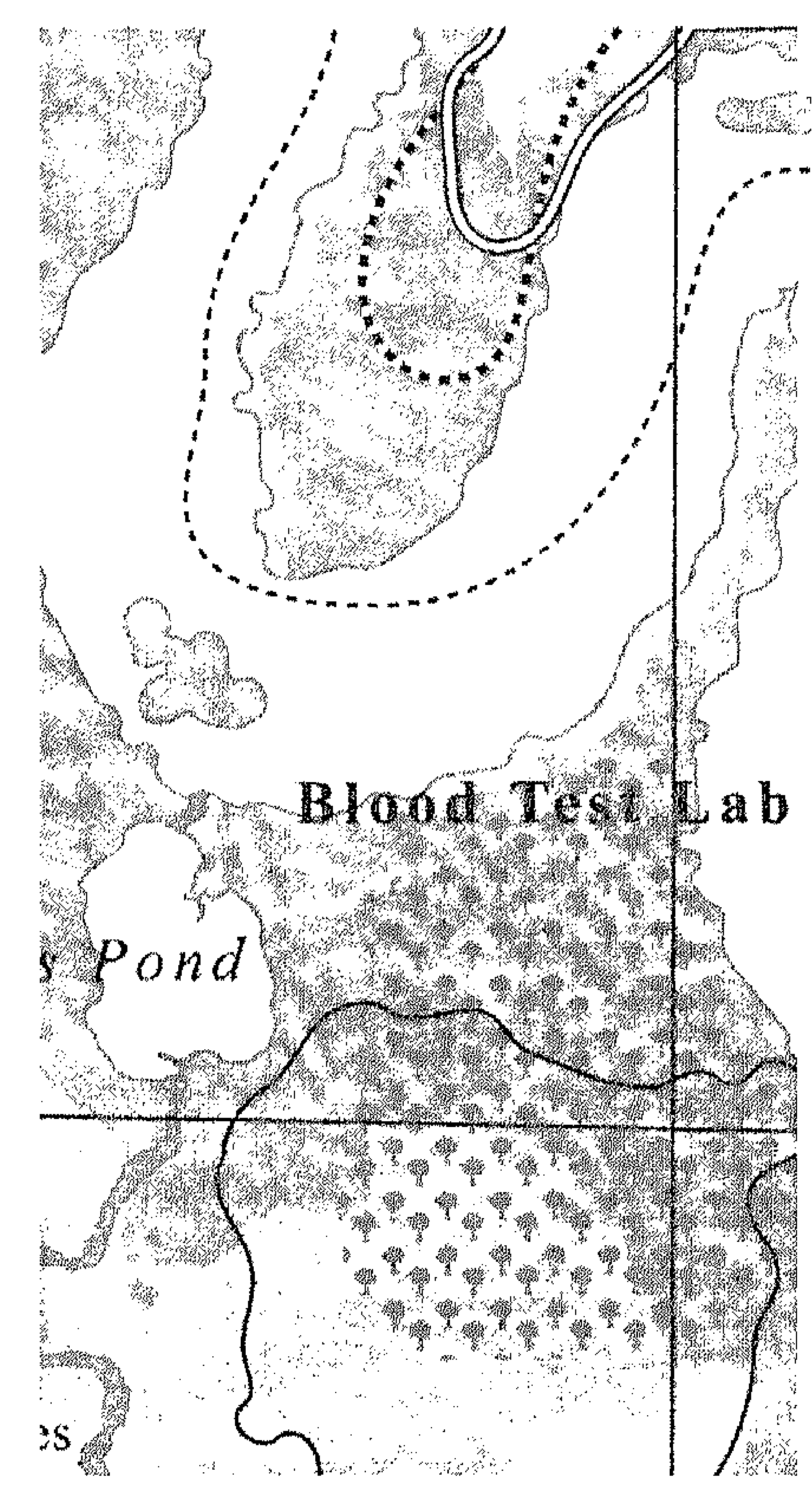




\section{Abstract}

\section{Introduction}

The effects of quality improvement strategies are sometimes limited in spite of a systematic development approach. What elements play a role in the change process is not yet fully understood.

\section{Objective}

To explore this 'black box' of change, by analysing the barriers and facilitators general practitioners (GPs) perceive during the change process.

Methods

Qualitative study among GPs who participated in the quality improvement strategy arm of a randomized clinical trial on blood test ordering for unexplained complaints (UCs). The strategy was based on a national guideline that advocates delayed test ordering in patients presenting with UCs. Each GP's change process was assessed by means of a semi-structured interview about barriers to and facilitators of change.

\section{Results}

Twenty-four interviews were analysed. Important themes identified in the interviews were lack of problem awareness, the time and effort it takes to change, influence of patients and the pros and cons of the changed behaviour.

\section{Conclusion}

The themes can be summarized into one comprehensive issue: the GPs lack a sense of urgency to change. An important explanation seems to be that two questions from the problem analysis prior to the development of the strategy had not been adequately answered: "Is the GPs' current behaviour a problem and does the problem have consequences for patients?" and if so, "What is the extent of the problem?." As a result, insufficient attention was given to applicability issues, such as time investment, costs and patient and practitioner satisfaction and anxiety. 
Exploring the black box of change $\mid 159$

\section{Introduction}

Most strategies to improve professional behaviour are only moderately effective ${ }^{1,2}$. Possible reasons are engrained routines and the use of inadequate methods to design and evaluate change strategies ${ }^{3-5}$. A relevant solution is to use a systematic approach in designing a change strategy ${ }^{6}$. Nevertheless, the effects of such strategies sometimes remain disappointing because a prior determinant analysis is frequently lacking and the innovation strategies that are used are mostly not theory driven ${ }^{7}$. Sometimes, barriers and facilitators have been analysed in advance but not used in the design ${ }^{8,9}$.

Several models about changing individuals' behaviour indicate that change is usually a stepwise process, during which the target group can experience various problems in achieving the proposed change ${ }^{10,11}$. The precise elements that play a role in this process are not yet fully understood. Although Flottorp et al. $^{12,13}$ carefully designed a quality improvement strategy based on barriers identified previously, even this strategy had little effect in changing practice. Though they tried to explain this in a process evaluation, no detailed insight was obtained into the change process itself, which largely remains a black box ${ }^{14,15}$. The objective of this paper is to explore this black box of change at a time when the practitioners involved are actually in the middle of the change process, by analysing the barriers and facilitators that GPs perceive 'during' such a change process. To our knowledge, such analyses have scarcely been reported in the literature. We took account of the interactions between a quality improvement strategy, its participants and their environment by focussing on GPs who participated in a strategy to improve their blood test-ordering behaviour for patients presenting with unexplained complaints (UCs), as defined in a national guideline ${ }^{16}$. This strategy was applied in a randomized clinical trial in which three groups of GPs were compared: Group 1 was instructed to order blood tests directly at the first consultation. GPs in Group 2 were instructed to propose a watchful waiting approach to their patients and GPs in Group 3 were instructed to try and postpone test ordering as well, but they also participated in a quality improvement strategy that supported them in postponing test ordering. The theory- driven strategy had been systematically designed and was based on a problem analysis that has been published previously (Box 10.1) ${ }^{6,17}$.

The question we wanted to answer was what are crucial barriers and facilitators during the change process among GPs who have been stimulated to postpone blood test ordering in patients presenting with UCs? 
Box 10.1

Topic
UCs in general practice.

Problem

When patients present to a GP with UCs, diagnostic blood tests are frequently ordered. As the risk of serious pathology in these patients is low, the probability of false-positive test results is relatively high. This may lead to a cascade of further diagnostic testing, anxiety and somatization. Recommended behaviour

Applying a 4-week watchful waiting period (based on a guideline from the Dutch College of General Practitioners). If complaints persist, a limited set of tests (erythrocyte sedimentation rate, haemoglobin, thyroid stimulating hormone, glucose) is indicated.

Most important barriers (prior to the quality improvement strategy)

Personal routines, tolerance of diagnostic uncertainty, pressure by patients to perform laboratory testing (even if patients do not explicitly ask for this), time pressure and tactical motives for test ordering. Educational methods selected on the basis of barriers and facilitators

General

Repeated message provision, education based on problems experienced by GPs in daily practice, offering opportunities to practice new behaviour. Two small group interactive meetings and one personalized practice visit. Supplying GPs with written course materials.

Routines

Formulating routines and alternative routine, setting goals for change, practicing in GPs' own practice.

Tolerance of diagnostic uncertainty

Case illustrating diagnostic accuracy to overcome knowledge deficiencies about (limited) diagnostic accuracy of tests and to visualize risks of pathology. Skills training to discuss uncertainty with patients and colleagues providing examples of successful explanations. Perceived pressure by patients

Communication skills training based on GPs' personal barriers, growing complexity of training situation; opportunities to practice in GPs' own practice and receive feedback. Educational materials for patients.

Time pressure

Analysing the sources of time pressure. Colleagues giving each other suggestions.

Tactical motives

Provision of alternative tactical strategies.

Format

Small group meeting 1

Part 1: Interactive explanation of diagnostic value of tests for patients with UCs and effect of watchful waiting approach on diagnostic value.

Part 2: Discussion of difficulties experienced in practice when dealing with patients presenting with UCs.

Individual goal setting to change behaviour in GPs' own practice.

Small group meeting 2

Part 1: Discussion about experiences with behaviour change. Searching for solutions to barriers that have arisen. Part 2: Practicing difficult situations by means of video vignettes. Setting new individual goals to change one's own behaviour.

Practice visit

Discussing individuals' barriers to change and providing suggestions to overcome these, based on stage of change. In between meetings, GPs get the opportunity to work on their goals to change their behaviour.

Course materials

Course book; leaflets for patients with information about UCs; diaries about complaints and food intake to hand out to patients to fill in and later discuss together; video message for the waiting room, explaining to patients the use of watchful waiting. 
Exploring the black box of change $\mid 161$

\section{Methods}

Comprehensive, semi-structured interviews were conducted with GPs as a part of the practice visit that belonged to the quality improvement strategy. We chose for this method because it gave us the opportunity to discuss thoroughly the determinants which we expected to be different in each individual GP. The interviews took place during the practice visit, which was part of the quality improvement strategy.

\section{Selection of participants}

The study population consisted of all GPs who were participating in a trial on blood test ordering for patients with UCs and had been randomized to the quality improvement strategy arm of this trial. Randomization in the trial took place at the practice level. The full protocol of the study has been published elsewhere ${ }^{18}$. The GPs were recruited in the southern and western parts of the Netherlands by mail and telephone using address lists of all GPs in a certain area. Participating practices were situated in rural as well as urban areas. All participants $(n=26)$ were visited at their practices by one of the researchers (MAB or $\mathrm{HK}$ ), as part of the quality improvement strategy.

\section{Data collection}

During the practice visit, each GP's change process was assessed by means of a semi-structured interview. All interviews were done by two female interviewers, MAB and HK. Both are medical doctors. The first graduated as a $G P$, the second ended vocational training in general practice prematurely. Practice visits were scheduled at least three months after the second small group meeting. The small group meetings were moderated by GPepidemiologists for the epidemiological part of the first meeting and by behavioural scientists who teached at the institutes of vocational training in general practice for the communication parts of both meetings. Approximately four GPs participated in a meeting at the same time. GPs were informed that the interview was not intended to judge their functioning as physicians but to see how change was progressing and to make suggestions to support the process if possible. The topics included in the scenario of the interviews are summarized in Table 10.1 and are based on models of changing behaviour. The first two questions were rather open ended: "Do you remember the previous meeting, and if so, what did you plan to change?" and "How did things go after this meeting?" Depending on the answers of the GPs, topics were further elaborated. When a GP did not address the topics of the scenario spontaneously, the interviewer introduced them. When barriers to change came 
$162 \mid$ Chapter 10

up during the interview, which was always the case, these were subsequently used to provide suggestions to overcome them.

The interviews were recorded on audiotape and field notes with key issues were taken as a backup. The tapes were transcribed verbatim. Age and number of years of experience as a GP were recorded.

Table 10.1 Topics included in the interviews, based on the eclectic change model by Grol and Wensing.

The model distinguishes five stages in the change process, which can each be divided into two substages. The substages are indicated in brackets.

Orientation (awareness of the problem and the innovation; interest and involvement):

Messages remembered from the small group meetings

Personal experiences since the second small group meeting

Insight (understanding; insight into own routines and deviations from target behaviour): Perceived learning effects of the strategy

Valuation of one's own diagnostic test-ordering behaviour

Acceptance (positive attitude and motivation to change; intentions or decisions to change):

Motivation to change

Expectations about difficult situations

Expectations of effects of change

Ways to overcome to barriers

Plans and goals to change behaviour

Change (actual adoption in practice; confirmation of benefit; value of change):

Elements of behaviour that have been changed

Positive and negative experiences with immediate and postponed testing

Activities undertaken to change, e.g. seeking information, practicing or changing routines

Effects of change on environment and vice versa, e.g. colleagues and patients

Investments in change

Maintenance (integration into routines; embedding within the organization):

Difficulties maintaining the change achieved

Experiences with embedding new routines into the organization

\section{Analysis}

The interviews were uploaded and coded using Atlas/ti software (version 4.2). The approach resembles a framework approach. Open coding was used as much as possible, though the authors naturally were aware of the literature on stages of change and the interview had been structured according to the existing models of changing behaviour. Thus, some deductive elements were added to inductive elements. One author (MAB) coded all interviews. Each interview was also coded by one of two other authors (HK or TW), independently from both the first coder and the other second coder. A cyclic approach was used to add and adapt codes. Single passages of text could get different codes. Differences in coding were discussed and consensus was sought. Similar codes were combined. Subsequently, we used an eclectic model of change, developed by Grol and Wensing ${ }^{10}$, to structure the findings 
after the coding process was finished, for two reasons (Table 10.1) ${ }^{19,20}$. Firstly, stages are widely used to describe the change processes of individuals and the model we used summarizes these. Secondly, it reflects the basic structure of the interviews. If codes did not fit into the model, we somewhat adjusted the categories of the model.

As proposed by the same authors, the barriers and facilitators within each stage were labelled with one of the following six levels: the innovation itself (applying watchful waiting), the individual professional, the patient, the social context, the organizational context and the economic and political context ${ }^{10}$.

\section{Results}

Population

All 26 GPs participating in quality improvement strategy of the trial were interviewed. None of the GPs had any objections against the interview. The length of the interviews was approximately approximately 45 minutes. The majority $(80 \%)$ were male. Regions and settings were equally divided between the south $(54 \%)$ and west of the country $(46 \%)$ and between urban $(50 \%)$ and rural settings $(50 \%)$. The mean age of the respondents was 47.5 years and they had an average of 13.5 years of experience as a GP. The interviews were recorded after an average of 7.3 months (range 3-10) into the intervention period. Of the participating practices, 10 were single handed. Two GPs who were running a joint practice decided not to complete the study, though some of the topics were discussed in one joint interview with these two GPs. From the other practices, only one GP per practice participated in the study. Data from all but one interview (24) were available for analysis due to technical problems.

All participants set objectives to change their behaviour. The objectives ranged from 'to suggest patients with UCs to come back in the afternoon, because then I have more time' to 'better clarify the patient's fears'.

\section{Change process}

Barriers and facilitators have been summarized in an appendix which is available online.

Each participant mentioned several barriers and facilitators that fitted into more than one stage of the change process. Most of the codes and comments related to the 'positive attitude' stage. Barriers generally outnumbered the facilitators. All stages are illustrated below with quotations from the interviews. 
$164 \mid$ Chapter 10

\section{Awareness and interest}

The first stage in the change process is particularly related to becoming aware of the problem and the innovation and then becoming interested in them. The fact that all participants voluntarily applied to participate in the trial implies that they were most likely aware of and interested in the innovation. This is reflected by the limited number of comments relating to this stage and the facilitators referred to. However, several GPs mentioned, contrary to their prior expectations, that they did not see many patients with clear UCs. In addition, a few GPs were not greatly interested in this topic because they did not experience many problems with testing in daily practice (Box 10.2).

Box 10.2 Comments on awareness and interest

(GP 11, female) "Sure, but l'd expected to see far more of such people than I did. May be I'm being more selective."

(GP 5, male) "We don't see it as a problem. If people ask for blood tests, that's no problem to us, nor to the patients. You get problems if you start to change the pattern that's developed over the years. Because that's time-consuming."

\section{Understanding of innovation and insight into one's own routines}

In the next stage of the change process, GPs acquire a clear understanding of what the improvement entails and develop insight into their own performance, including the deviations from the target behaviour. Several participants perceived the information that was given as part of the quality improvement strategy, especially the numerical illustrations of the limited diagnostic value of immediate test ordering, as an important facilitator of change. Recent vocational training was also perceived as a facilitator of adopting the watchful waiting approach. However, even after the instructions provided as part of the quality improvement strategy, several GPs overestimated the accuracy of blood tests for UCs.

A determinant of insight into their own routines that was mentioned several times was whether or not the participants saw room for improvement in their behaviour. Other determinants reflected skills and personal characteristics (Box 10.3).

\section{Positive attitude and intentions or decisions to change}

In the following stage, GPs balance the advantages and disadvantages of the watchful waiting approach against those of immediate blood test ordering.

Many GPs claimed that the advantages of a watchful waiting approach were outweighed by the advantages of immediate test ordering, and the 
disadvantages of watchful waiting. They found that testing was efficient, satisfied patients, had diagnostic or strategic value, reassured both patients and GPs and was not costly.

Actually, several GPs did not experience any disadvantages of their current approach of immediate test ordering. According to the GPs, patients had a strong influence on their test-ordering behaviour.

Few participants mentioned clear intentions to change their routines (Box 10.4).

Box 10.3 Comments on understanding the innovation and insight into one's own routines.

(GP 24, male) "I never used to order tests for people who had felt tired for a week anyway."

(GP 15, male) "I think I'm a bit of a perfectionist. And such a vague diagnosis, that's hard to sell."

(GP 19, female) "I think that, above all, I want to do the right thing, in the medical or technical sense of the word. And I often feel that's not what l'm doing when l'm doing consultations and I find myself ordering blood tests just to reassure the patient for the moment. You think to yourself: right, these tests are not going to produce any abnormal results. And that's the end of it."

(GP 23, female) "Well, I do things like PSA [prostate-specific antigen], as I don't trust my own rectal examination."

Box 10.4 Comments on positive attitude and intentions or decisions to change.

(GP 7, male) "These patients often come with certain ideas in their heads which make me think I'll need some additional arguments to talk them out of that."

(GP 9, male) "The point is, if I have the idea that I don't feel like waiting for another two weeks or a month while nothing is being done. Then I just want to get going. It might be a thyroid problem or a kidney problem, and then I find it hard to say why don't you wait for another month and endure the itch."

(GP 22, female) "What I normally do is give them the form for the lab tests, and nine out of ten times, that's the end of it."

(GP8, male) "People are becoming more and more worried, what with the Internet and all that stuff. They read all kinds of things and become more and more uncertain about their own health. And they want clarity as soon as possible. And you notice that, so I have a greater tendency to order tests."

(GP 10, male) "Of course it also depends on other factors, internal and external, If you're very busy, you're more likely to say right let's have some tests done. That means the problem is deferred for the moment, l'll get some more information to go on and some time to think about it."

(GP 17, male) "So you see the results of tests ordered by your colleague, who's taken over, and you think, goodness, that's a lot of tests, a whole lot of tests." 
$166 \mid$ Chapter 10

\section{Actual adoption in practice and confirmation of benefits}

After GPs decide to change, they need to try out the watchful waiting approach on a small scale and evaluate whether they are satisfied with the new approach or not. GPs who had a successful tryout found that their skills improved and failed to find the anticipated negative effects of watchful waiting. GPs who relapsed mentioned several barriers, especially as regards the feasibility of a watchful waiting approach (Box 10.5).

Box 10.5 Comments on actual adoption in practice and confirmation of benefits.

(GP 22, female) "Well, there was no one saying they didn't want that, no. I think they all liked it."

(GP 7, male) "And if you don't order them the first time round and explain to them why, that tests would probably show nothing and their complaint is probably something that will resolve spontaneously or has a different kind of origin, you find that people start to think about it and don't return."

(GP 20, female) "I think the main disadvantage is that it takes a lot of time. That I think is a major disadvantage of my way of working."

(GP 14, male) "And l've found several times, after I had actually postponed it and then did it anyway after a while, the tests did show up something."

\section{Integration in routines and embedding within the organization}

Finally, the new approach needs to become routine behaviour and must be embedded in the organization. Few GPs mentioned barriers or facilitators relating to the integration stage, and none of them mentioned any factors influencing embedding. Facilitators included the availability of tactics to prevent relapse into old routines and the structure of the quality improvement strategy with its repeated educational meetings (Box 10.6).

Box 10.6 Comments on integration in routines and embedding within the organization.

(GP 22, female) "I should say that the way you people organize things does help you keep it up. Because of course research into the way people learn has shown that repetition and returning to it time and again does make you actually do it, right?"

(GP 6, male) "I can assure you that the routine of blood tests is really gone." 
Exploring the black box of change $\mid 167$

\section{Conclusion}

\section{Summary of main findings}

The aim of this study was to look inside the black box of behavioural change by identifying crucial barriers to and facilitators of change during the actual change process that GPs went through. Important aspects mentioned by the interviewees appear to be the lack of problem awareness, the time and effort it takes to change, the influence of the patients and considerations about the pros and cons of the behaviour change.

\section{Strengths and limitations}

The main strength of this study was that, as far as we know, it was among the first to explore experienced barriers and facilitators during the course of a change process instead of perceived barriers beforehand. No purposive sampling was done, but the sample consisted of GPs with a range of characteristics, e.g. both sexes, different levels of experience as a GP and different practice types. The group might, however, represent a selection of unusually motivated GPs, as they participated voluntarily. This might negatively influence transferability of results. However, even this well-motivated group saw mostly barriers in the early stages of the change process. The credibility of our findings is high. The types of barriers and facilitators that were mentioned by the participants were also mentioned in the change process of other behaviours. In addition, it is known that guideline adherence is also negatively influenced by similar factors, such as when practice routines need to be changed ${ }^{21}$. To triangulate our findings in order to check for consistency of our data, we planned to compare the change process as reported by the GP to the actual change in test ordering as measured by the numbers of tests ordered. Unfortunately, the test-ordering information was insufficient to draw meaningful conclusions. However, there were no quotes in our data set that contradict our general findings.

Interviewing GPs implies the limitation of only retrieving determinants of behaviour that participants are aware of. Unconscious barriers, e.g. lack of skills, do not always emerge. The model we used to categorize the barriers and facilitators is restricted to changes by individual practitioners and does not, for instance, describe organizational change. This made it suitable for our findings as individual change is the target of this strategy. While categorizing the barriers and facilitators within the stages of the model, we felt that the 'innovation' aspect in the 'orientation' stage covers not only the new routine itself but also the comparison with previous behaviour, the appreciation of the quality improvement strategy and, in a research setting, the influence of the trial on the 
$168 \mid$ Chapter 10

intended behaviour. We also decided to add 'awareness of the problem' to the 'awareness of the innovation' substage.

\section{Comparison with existing literature}

Our study revealed barriers to and facilitators of change across the consecutive stages of the change process. However, determinants relating to the stages at both extremities of the change process were mentioned less frequently than those relating to the intermediate stages. The absence of factors relating to the early stages can be explained by the fact that the interviewees were participating in a trial and were therefore almost by definition aware of the topic. The finding that few of the determinants that were mentioned related to the final stage might be a sign that the interviews were held somewhat too soon as reaching the maintenance stage takes time. As a result, the results on the advanced stages may be incomplete. In addition, the chosen methodology, interviewing GPs, tends to emphasize the insight and acceptance stages because these are more 'cognitive' than the others. However, a more likely explanation is that the strategy has been less successful than intended. Most GPs were not yet at the stage of actually changing their behaviour. This is supported by the large numbers of barriers mentioned by the interviewees that related the insight and acceptance stages. A look at these barriers shows that they can be summarized into one comprehensive issue across the stages, namely the fact that the GPs lacked a sense of urgency to change. Apparently, the participants did not become permanently convinced that their test-ordering behaviour needed to change. The limited difference in determinants between our interviews and the diagnostic analysis on which the quality improvement strategy was based, corroborates this ${ }^{17}$. One explanation for this lack of a sense of urgency is that the participants were as a rule not willing to invest in any quality improvement of their functioning and generally preferred to stick to old habits. On the other hand, the participants did voluntarily and actively participate in the quality improvement strategy meetings. An alternative explanation for the GPs' lack of a sense of urgency is that two questions from the problem analysis prior to the development of the strategy had not been adequately answered: "Is the GPs' current behaviour a problem and does the problem have consequences for patients?" and if so, "What is the extent of the problem?" The sense of urgency, in the sense of an individual's motivation to change specific behaviour, has been recognized as a facilitator before ${ }^{22}$. The guideline on which the quality improvement strategy is based discusses the low diagnostic accuracy of tests and the value of a watchful waiting approach, from the viewpoint of Bayesian decision theory. However, support for this theory with scientific evidence from practice-based research is still limited. In addition, when we compare the guideline with the Appraisal of Guidelines for Research and 
Evaluation (AGREE) criteria for the methodological quality of clinical guidelines, it appears that relatively little attention has been devoted to its applicability and to patients' experiences and expectations ${ }^{23}$. Greenhalgh et al. ${ }^{24}$ also emphasized that complex behavioural change needs to be seen as a process rather than an event, a process in which GPs interact with the innovation and their environment. To add to the complexity, not only evidence but also the GPs' intuition may be of value in this process. Greenhalgh ${ }^{25}$ suggested that systematic critical reflection about intuitive judgements in dialogue with professional colleagues may improve these 'intuitive powers'.

\section{Implications}

When guideline developers take these aspects into account, they may produce different, more easily applicable, guidelines, providing better answers to GPs' practical needs. Quality improvement strategies based on these improved guidelines may then be more effective in creating a sense of urgency to change, which in turn appears to be a condition priming true behavioural change. This implies that evidence about applicability issues, such as time investment, costs and patient and practitioner satisfaction and anxiety, needs to be made available to guideline developers. In addition, differences in patient preferences should be evaluated, so that the GPs' ideal of delivering tailored patient care can be met. In conclusion, to develop an effective quality improvement strategy, a thorough problem analysis is needed in advance. This should address the size of the problem and its consequences especially for patients, the applicability of the target behaviour and differences in patient preferences. 


\section{References}

1. Grimshaw JM, Shirran L, Thomas R, Mowatt G, Fraser C, Bero L, Grilli R, Harvey E, Oxman $A$, O'Brien MA. Changing provider behaviour: an overview of systematic reviews of interventions. Med Care 2001;39: 112-45.

2. Bero LA, Grilli R, Grimshaw JM, Harvey E, Oxman AD, Thomson MA. Getting research findings into practice: closing the gap between research and practice: an overview of systematic reviews of interventions to promote the implementation of research findings. BMJ 1998; 317: 465-8.

3. Wensing $M$, van der Weijden $T$, Grol R. Implementing guidelines and innovations in general practice: which interventions are effective? Br J Gen Pract 1998;48:991-7.

4. Davis $D A$, Thomson MA, Oxman $A D$, Haynes RB. Changing physician performance. $A$ systematic review of the effect of continuing medical education strategies. JAMA 1995;274:700-5.

5. Campbell $M$, Fitzpatrick $R$, Haines $A$ et al. Framework for design and evaluation of complex interventions to improve health. BMJ 2000;321:694-6.

6. van Bokhoven MA, Kok G, van der Weijden T. Designing a quality improvement intervention: a systematic approach. Qual Saf Health Care 2003;12:215-20.

7. Fleuren MAH, Wiefferink K, Paulussen TGWM. Determinants of innovation within health care organizations: literature review and Delphi study. Int J Qual Health Care 2004;16:107-23.

8. Bosch $M$, van der Weijden $T$, Wensing $M$, Grol R. Tailoring quality improvement interventions to identified barriers: a multiple case analysis. J Eval Clin Pract 2007;13:181-8.

9. Shaw $B$, Cheater $F$, Baker $R$ et al. Tailored interventions to overcome identified barriers to change: effects on professional practice and health care outcomes. Cochrane Database Syst Rev 2005;3:CD005470.

10. Grol $R$, Wensing $M$. What drives change? Barriers to and incentives for achieving evidencebased practice. Med J Aust 2004;180:S57-S60.

11. Grol R, Wensing M. Effective implementation: a model. In Grol R, Wensing M, Eccles M (eds) Improving Patient Care: The Implementation of Change in Clinical Practice, Edinburgh, UK: Elsevier, 2005

12. Flottorp $S$, Oxman $A D$. Identifying barriers and tailoring interventions to improve the management of urinary tract infections and sore throat: a pragmatic study using qualitative methods. BMC Health Serv Res 2003;3:3.

13. Flottorp $S$, Oxman AD, Hávelstrud $K$, Treweek $S$, Herrin J. Cluster randomised controlled trial of tailored interventions to improve the management of urinary tract infections in women and sore throat. BMJ 2002;325:67.

14. Flottorp $S$, Håvelstrud $K$, Oxman $A D$. Process evaluation of a cluster randomized trial of tailored interventions to implement guidelines in primary care-why is it so hard to change practice? Fam Pract 2003;20:333-9.

15. Grol R, Baker R, Moss F. Quality improvement research: understanding the science of change in health care. Qual Saf Health Care 2002; 11: 110-1.

16. Dinant GJ, van Wijk MAM, Janssens HJEM, Somford RG, de Jager CJ, Beusmans GHMI, Dijkstra RH, Wiersma Tj. NHG-standaard bloedonderzoek. Algemene principes en uitvoering in eigen beheer. [Dutch College of General Practitioners guideline 'Blood testing. General principles and use by GP']. Huisarts Wet 1994;37:202-11.

17. van der Weijden $T$, van Bokhoven MA, Dinant GJ, van Hasselt CM, Grol RPTM. Understanding laboratory testing in diagnostic uncertainty: a qualitative study in general practice. Br J Gen Pract 2002;52:974-80.

18. van Bokhoven MA, Koch $H$, van der Weijden T, Bindels PJE, Grol RPTM, Dinant GJ. Blood test ordering for unexplained complaints in general practice, the VAMPIRE randomised clinical trial protocol. [ISRCTN55755886]. BMC Fam Pract 2006;7:20.

19. Grol RPTM. Implementing guidelines in general practice care. Qual Health Care 1992;1: 184-91. 
20. Grol $R$, Wensing $M$, Eccles $M$. Improving patient care. The implementation of change in clinical practice. London: Elsevier, 2005.

21. Grol R, Dalhuijsen J, Thomas S, Veld C, Rutten G, Mokkink H. Attributes of clinical guidelines that influence use of guidelines in general practice: observational study. BMJ 1998;317: 858-61.

22. Kennedy T, Regehr G, Rosenfield J, Roberts W, Lingard L. Exploring the gap between knowledge and behavior: a qualitative study of clinician action following an educational intervention. Acad Med 2004;79:386-93.

23. AGREE-Collaboration. Appraisal of Guidelines for Research and Evaluation (AGREE) Instrument $2004 \mathrm{http}: / / \mathrm{www}$.agreecollaboration. org (accessed on July 14, 2006).

24. Greenhalgh $T$, Robert $G$, Macfarlane $F$, Bate $P$, Kyriakidou $O$. Diffusion of innovations in service organizations: systematic review and recommendations. Milbank Q 2004;82:581-629.

25. Greenhalgh T. Intuition and evidence-uneasy bedfellows? Br J Gen Pract 2002;52:395-400. 


\section{Chapter 11}

Special methodological challenges when studying the diagnosis of unexplained complaints in primary care

Marloes A. van Bokhoven, Hèlen Koch, Trudy van der Weijden, Geert-Jan Dinant

$J$ Clin Epidemiol 2008;61:318-322

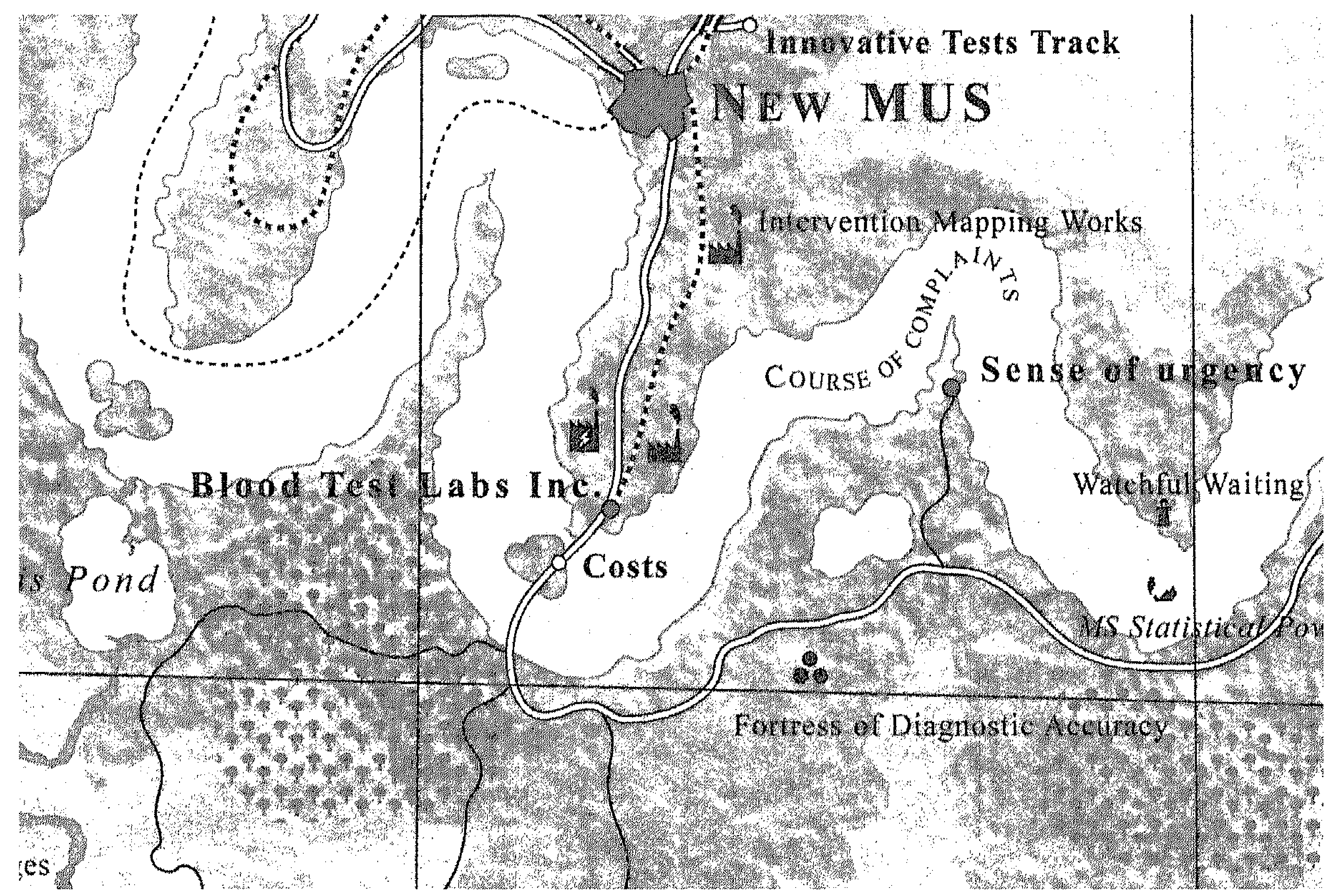




\section{Introduction}

Unexplained complaints (UCs) can be defined as complaints that, after a proper history taking and physical examination, do not seem to be explained by either somatic or psychiatric diseases, nor by the patient's psychosocial context ${ }^{1}$. Among the UCs most frequently seen in primary care are fatigue, abdominal complaints, dizziness, musculoskeletal complaints, and headach ${ }^{2,3}$. Thus, UCs reflect a broad range of clinical pictures. In the literature, these complaints are frequently referred to as medically unexplained symptoms, although some authors use this term for somatoform disorders as well ${ }^{4}$. Therefore, we prefer the term "unexplained complaints." Furthermore, UCs will often be self-limiting, but may also be the first sign of serious disease. These diagnostic uncertainties make physicians feel uneasy when dealing with patients presenting with UCs. This may result in unnecessary reconsulting, superfluous laboratory and other testing, or a prolonged period of waiting and seeing ${ }^{5}$. In addition, the burden of disease in terms of both quality of life and costs may be high, especially when complaints become chronic ${ }^{6}$.

For these reasons, a better understanding of the proper diagnostic work-up when patients present with UCs is needed ${ }^{7}$. This article describes the obstacles and challenges of such a research. Based on the international standards for reporting the accuracy of diagnostic tests, we concentrate on the following issues: how to select the proper study population; how to define accurate reference standards; and how to define useful outcome measures. However, we start with some comments on how to reach a clear definition of UCs, because this influences the other issues. Several individual obstacles that are described in this commentary can be found in research on other complaints as well, but in our opinion their combination is typical for UCs. We chose the perspective of primary care to build up the article, because the prevalence of UCs is relatively high in this setting due to the early, not fully developed stage of many complaints presented. This implies that diagnostic uncertainty is high in this group.

\section{Definition: generalizability versus reproducibility}

"Unexplained" implies the subjective judgement of a complaint by the general practitioner (GP). Whether or not a GP considers a complaint unexplained depends on GP-related factors such as prior knowledge about the patient and his or her context, the information gathered during the consultation, tolerance of uncertainty, consultation skills, and the labelling of complaints as syndromes, such as irritable bowel syndrome. On the other hand, the judgment is influenced by patient factors such as the severity and pattern of the complaints and the 
$176 \mid$ Chapter 11

patients' ability to verbalize the complaints. To generate research findings that are generalizable and relevant to daily practice, researchers thus depend on the GP to label the patient's complaint as "unexplained". Inter-GP differences, recurrence patterns, and combinations of complaints might be relevant. However, researchers tend to aim for reproducibility, as subjectivity might cause bias. They might therefore want to use a strict definition and restrict inclusion to a small set of complaints and to incident cases. In addition, researchers have to decide whether to focus on UCs of recent onset or of chronic character. The latter are usually complaints for which GPs have become convinced that no somatic explanation is available. in other words, "unexplained complaint" has become a 'psychiatric' diagnosis instead of a diagnostic problem, for example, the diagnosis according to the Diagnostic and Statistical Manual of Mental Disorders (DSM) diagnosis of 'somatization disorder'. When chronic UCs no longer present diagnostic challenges, they are beyond the scope of this paper.

So, it is difficult to compare the existing research findings on UCs because researchers use different definitions. To overcome this problem, Fink et al. recently suggested the use of a classification specifically for primary care. Others suggested multiaxial descriptions comparable to the DSM-criteria ${ }^{10,11}$. Though this may improve comparability, it does not facilitate the abovementioned choices of in- and exclusion criteria and the duration of the complaints. In summary, the challenge for the researcher investigating UCs is to find a balance between the heterogeneity of the concept of UCs that reflects daily practice and the unequivocal definitions that are required in research.

\section{Example 1}

Schilte researched the diagnosis of mild somatization in general practice ${ }^{12}$. A definition of somatization frequently used for research purposes was the socalled "abridged DSM-III-R somatisation"13. However, GPs generally do not assess somatization along a standardized set of criteria, by means of an interview or questionnaire. To translate their study findings to daily practice, Schilte et al. examined the relation between the GPs' clinical judgments and the results on a standardized patient questionnaire ${ }^{14}$. The GPs graded the degree of somatization ( 1 no somatization - 5 severe somatization) and answered questions about problems in the communication with their patients. The symptoms of somatization on the patients' questionnaire were according to the abridged DSM-III-R. It appeared that somatization according to the GPs' clinical judgement and to the standardized measurement were weakly related to each other, but that both definitions showed acceptable construct validity. The authors recommend that for research addressing somatization as a practical clinical problem the operationalization of somatization should include the clinical 
judgment of the practitioner. As a result of this, the focus widens from comorbid mental disturbances to communication aspects.

\section{Selection of patients}

The subjective factor in the definition of "unexplained complaints" also influences patient selection. "Unexplained" cannot be defined in a written set of in- and exclusion criteria that are applicable without involvement of the GP, for example, in medical record reviews, screening instruments, or diagnostic interviews. In addition, in the medical records GPs usually do not register the unexplained character of patients' complaints. They note working hypotheses in very different ways, for example, symptom diagnoses, but these notations are used for explained complaints as well. It implies that GPs necessarily play a role in patient selection. This is difficult for GPs, for four reasons. First, they need to remind themselves of the research project while seeing a patient presenting with UCs. Before a GP realizes that a patient meets the inclusion criteria, he or she may already have become involved in successive stages of the consultation and may have discussed diagnostic or therapeutic plans with the patient. The moment at which the patient is eligible might then be over ${ }^{12,15}$. In research projects that include patients presenting with complaints relating to different tracts, as may be the case in studies on UCs in general, the GPs have many but not very strong cues to remind them of the project.

The second difficulty for the GPs is that, in spite of instructions given by the researchers, it might be difficult for them to decide whether the complaint presented by the patient is "unexplained enough" to meet the selection criteria. There are differences in the definition of UCs not only between GPs but also within individual GPs, reflecting a continuum of levels of certainty ${ }^{16}$. In diagnostic research, it is important to know the continuum ranging from "diseased" to "nondiseased." It is therefore relevant to know which part of the continuum each GP considers eligible for participation. This may be assessed by means of noninclusion analysis.

The third problem might be the most difficult to deal with: the research project itself may influence the selection process. Being involved in a research project and realizing that a problem presented by a patient might remain unexplained could trigger GPs to ask a few extra questions, for instance about psychosocial influences, leading to an explanation of the complaints that the GPs would not have come up with in routine care. The same effect may be caused by knowledge of the items of the measurement instruments, especially when the diagnostics under research include signs and symptoms. It is known from other research topics that the feeling of being observed because of participation in a research project alone can influence behaviour (Hawthorne effect) although the 
size of this effect is incompletely known ${ }^{17}$. This problem might be overcome by means of triangulation techniques, for example, interviewing GPs afterwards about the process of patient inclusion, like it is common in qualitative research ${ }^{18}$. The above effects of the research project itself might lead to fewer eligible patients.

When, in spite of these difficulties, a GP finds an eligible patient, the fourth problem arises. Some GPs find it difficult to tell a patient that they are unable to explain their complaints, as part of the informed consent procedure, as they might experience it as a failure that they are unable to establish a diagnosis. For patients themselves, however, the UCs are a good reason for additional diagnostics ${ }^{19}$

\section{Example 2}

In a randomized clinical trial about blood test ordering for UCs in general practice (the VAgue Medical Problems In REsearch [VAMPIRE] trial), of which the data are currently being analyzed, the cost-effectiveness of immediate test ordering is compared to a watchful waiting policy of four weeks ${ }^{20}$. The participating GPs were instructed to select patients presenting with one of the following five complaints: fatigue, abdominal complaints, musculoskeletal complaints, weight changes, or itch, which they considered unexplained according to the definition given in a national guideline. The number of included patients was much lower than estimated based on a previous study about the prevalence of UCs in general practice ${ }^{2}$. All of the inclusion difficulties described in this paragraph were mentioned by participating GPs. To check if these have not resulted in a biased patient selection, a noninclusion study is currently performed in a sample of 10 participating practices, representing GPs who included many and GPS who included few patients. Records of all patients included in the VAMPIRE study in these 10 practices are compared to records of patients who presented the same complaints or were given the same working hypothesis as the study participants. Several characteristics of the patients' complaints are compared.

\section{Reference standard}

UCs lead to a broad, heterogeneous set of possible diagnoses, although the number of diagnoses depends on the complaint definition that has been chosen. As a result, there is no single test that can be used as a reference standard. There are three possible approaches to overcome this problem ${ }^{21}$.

The first is a diagnosis-oriented approach. In theory, one could try to use a combination of tests as a reference standard. Apart from difficulties in finding 
tests that are suitable, they are easily too invasive and therefore ethically not acceptable for application, especially because the probability of finding serious pathology in patients with UCs is very low. In addition, at the moment of testing it is sometimes not clear which disease is being sought for due to the broad differential diagnosis, so it is unknown which reference standard tests should be chosen.

The second approach is based on the presence of "pathology." In patients with UCs, it might be sufficient to make a gross distinction between the presence and absence of disease, with no further specification in a diagnosis. One method is to ask an expert panel to decide, based on test results. Another method is to follow-up the complaints for a predefined period of time and draw a conclusion afterward. A prerequisite is that the period is of sufficient length so that, if a patient has the suspected disease, this will have become manifest by the time the experts draw a conclusion. A third method is to combine both in a so-called "delayed type cross-sectional study," which means that an expert panel draws a conclusion about the presence of pathology after a certain followup period ${ }^{21}$. A prerequisite for the last two methods is that the "pathology" is not self-limiting during the follow-up period, because in that case no conclusion can be drawn at the end of it. When a diagnosis is established after follow-up, it might be biased by a new episode of complaints occurring during follow-up, which may be mistaken for the original episode. This is not a hypothetical risk, especially in UCs that are frequently self-limiting and can show a relapsing pattern. Both might be solved by a fourth method, in which the conclusion at the end of the follow-up period is drawn about pathology during the whole follow-up instead of at one moment. Two forms of bias remain, the first occurring when treatment during the follow-up period influences the conclusion after its termination and the second when new pathology develops so that it is not sure whether this explains the results of the test under research or reflects another situation (e.g., a patient with tiredness and a slightly elevated erythrocyte sedimentation rate who after some months is diagnosed as having Crohn's disease).

The third approach is based on a prognostic/therapeutic consequence. This approach fits in well with daily general practice, because of the tendency among GPs to assess the implications of health problems in terms of suffering and functional impairment in daily life, instead of a diagnosis only. Tests are used to discriminate between complaints that require immediate action and complaints whose natural course can be awaited ${ }^{22}$. The advantage of this approach is that it bypasses the difficult problem of drawing a diagnostic conclusion. However, this approach too might be biased by treatment that interferes with the prognosis.

The decision to adopt one of the last two approaches depends on the research question. 


\section{Example 3}

Muris et al. studied the diagnostic accuracy of symptoms, signs, and test results for the diagnosis of organic gastrointestinal disease among patients with nonacute unexplained abdominal complaints ${ }^{23}$. They did a follow-up of at least 1 year, during which all events were registered in the patients' records by the GPs. After follow-up, a panel of three GPs classified the diagnoses based on the international classification of problems in primary care. When the panel did not reach consensus a second panel, of professors in internal medicine and general practice, was consulted. Next, they divided all diagnoses into two categories: organic versus nonorganic. Finally, they compared neoplasms with all other diagnoses. In this way, they were able to find predictors and alarm signals of organic disease and neoplasms.

\section{Outcome measures}

As mentioned earlier, establishing a diagnosis in diagnostic research is not straightforward in patients with UCs. The options in the differential diagnosis include not only somatic diseases but also psychiatric diagnoses and complaints that become chronic, but for which no somatic explanation can be found. Naturally, outcome measures should reflect the research questions of a study. In addition to the diagnostic effects that are determined in a traditional diagnostic study, other types of outcome measures may be important as well when determining the value of a diagnostic test. One possible alternative outcome measure is costs. Because the probability of pathology in patients with Ucs is low, test ordering behaviour will not have a great impact on costs of individual treatment and care. However, because the group of patients with UCs is large and many tests are requested for this group, the total costs of testing may be high. A difficulty with cost-evaluation studies is that health technology assessment methodology, similar to most diagnostic study designs, is based on singular diagnoses, while in UCs the focus may be on "pathology" in general. A second type of alternative outcome measure consists of psychosocial effects on patient and physician, for example, anxiety and satisfaction. Both GPs and patients seek methods to reduce uncertainty, and testing might influence their psychological well-being ${ }^{24}$. A third type is that of strategic effects, for example, testing as an opportunity for not rewarding a referral request ${ }^{25}$.

\section{Example 4}

In the VAMPIRE study, which has been described in example 2, the first primary outcome measure is the diagnostic accuracy of blood tests for serious pathology (per test and in combinations relevant for general practice) related to 
signs and symptoms. The second is the effect of watchful waiting on the test characteristics. In addition, the study also pays attention to prognosis related outcome measures and costs. Outcome measures related to the GPs are, for example, level of insecurity and satisfaction with the consultation. Outcome measures related to the patient are satisfaction with care, anxiety, quality of life, utilization of health care facilities, and absence of work through illness. Related to the intervention are the costs of the training for GPs to effectively execute the watchful waiting approach.

\section{Discussion}

It may be concluded that UCs have several characteristics that distinguish them from nosologically described diseases: they are not as accurately defined, they may represent the beginning of a range of disorders, but in general practice, they are usually self-limiting, and reference standards for the diagnosis are lacking. In addition, research on these complaints is hampered by the fact that including patients is even more difficult than usual and by the fact that, though testing has limited diagnostic value, it may have "strategic" value. The combination of these characteristics makes diagnostic research into UCs not as straightforward as diagnostic research into well-defined diseases. This might be one of the reasons why such research has been sparse and adequate methodology has been lacking. Topics that deserve attention include both traditional diagnostic and nondiagnostic effects of testing, the early recognition of patients who are at risk to develop chronic complaints, the effects of a watchful waiting approach on the course of complaints, and implementation of new findings in daily practice. The further development of research methodology for this topic is a challenge in its own right. 


\section{References}

1. Dinant GJ, van Wijk MAM, Janssens HJEM, Somford RG, de Jager CJ, Beusmans GHMI, Dijkstra RH, Wiersma Tj. NHG-standaard bloedonderzoek. Algemene principes en uitvoering in eigen beheer. [Dutch College of General Practitioners guideline 'Blood testing. General principles and use by GP']. Huisarts Wet 1994;37:202-11.

2. van der Weijden $T$, van Velsen M, Dinant GJ, van Hasselt CM, Grol RPTM. Unexplained complaints in general practice. Prevalence, patients' expectations, and professionals' testordering behavior. Med Decis Making 2003;23:226-31.

3. Sheehan JD. The management of medically unexplained symptoms. Semin Gastrointest Dis 1999;10:30-6.

4. Burton C. Beyond somatisation: a review of the understanding and treatment of medically unexplained physical symptoms (MUPS). Br J Gen Pract 2003;53:231-41.

5. Knottnerus JA, Knipschild PG, van Wersch JWJ, Sijstermanns AHJ. Unexplained fatigue and hemoglobin: a primary care study. Can Fam Physician 1986;32:1601-4.

6. Katon WJ, Walker EA. Medically unexplained symptoms in primary care. J Clin Psychiatry 1998;59:2015-21.

7. Rosendal M, Olesen F. Fink P. Management of medically unexplained symptoms. BMJ 2005; 330:4-5.

8. Knottnerus JA, Dinant G-J. Medicine based evidence, a prerequisite for evidence based medicine. BMJ 1997;315:1109-10.

9. Fink $P$, Rosendal $M$, Olesen $F$. The classification of somatisation and functional somatic symptoms in primary care. Aust N Z J Psychiatry 2005;39:772-81.

10. Sykes R. Somatoform disorders in DSM-IV: mental or physical disorders? J Psychosom Res 2006;60:341-4.

11. Mayou R, Kirmayer LJ, Simon G, Kroenke K, Sharpe M. Somatoform disorders: time for a new approach in DSM-V. Am J Psychiatry 2005;162:847-55.

12. Schilte AF. Somatisation in general practice. Clinical assessment and the effectiveness of disclosing emotionally important events. Maastricht: Maastricht University, ISBN 9090148868; 2001.

13. Escobar Jl, Rubio-Stipec M, Canino G, Karno M. Somatic symptom index (SSI): a new and abridged somatization construct. Prevalence and epidemiological correlates in two large community samples. J Nerv Ment Dis 1989;177:140-6.

14. Schilte AF, Portegijs PJM, Blankenstein AH, Knottnerus JA. Somatisation in primary care: clinical judgement and standardised measurement compared. Soc Psychiatry Psychiatr Epidemiol 2000;35:276-82.

15. van der Horst HE. Irritable bowel syndrome in general practise. How effective is patient education and counselling?. Amsterdam: Vrije Universiteit; 1997.

16. Dinant GJ. Section 6: Diagnosis and decision-making. In: Jones R, Britten N, Culpepper $L$, Gass $D$, Grol $R$, Mant $D$, et al, editors. Oxford textbook of primary medical care. Oxford: Oxford University Press, ISBN 0192632191; 2004.

17. Braunholtz DA, Edwards SJ, Lilford RJ. Are randomized clinical trials good for us (in the short term)? Evidence for a "trial effect". J Clin Epidemiol 2001;54:217-24.

18. Holden JD. Hawthorne effects and research into professional practice. J Eval Clin Pract 2001;7:65-70.

19. van Bokhoven MA, Pleunis-van Empel MCH, Koch H, Grol RPTM, Dinant GJ, van der Weijden T. Why do patients want to have their blood tested? A qualitative study of patient expectations. BMC Fam Pract 2006;7:75.

20. van Bokhoven MA, Koch $H$, van der Weijden T, Bindels PJE, Grol RPTM, Dinant GJ. Blood test ordering for unexplained complaints in general practice, the VAMPIRE randomised clinical trial protocol. BMC Fam Pract 2006;7:20.

21. Knottnerus JA, Muris JW. Assessment of the accuracy of diagnostic tests: the cross-sectional study. J Clin Epidemiol 2003;56:1118-28. 
22. Knottnerus JA. Between iatrotropic stimulus and interiatric referral: the domain of primary care research. J Clin Epidemiol 2002;55:1202-6.

23. Muris JW, Starmans R, Fijten EH, Crebolder HF, Schouten HJ, Knottnerus JA. Non-acute abdominal complaints in general practice: diagnostic value of signs and symptoms. $\mathrm{Br} J \mathrm{Gen}$ Pract 1995;45:313-6.

24. Mushlin AI, Kern LM, Paris M, Lambert DR, Williams G. The value of diagnostic information to patients with chest pain suggestive of coronary artery disease. Med Decis Making 2005; 25:149-57.

25. Mushlin AI, Ruchlin HS, Callahan MA. Costeffectiveness of diagnostic tests. Lancet 2001; 358:1353-5. 


\section{Chapter 12}

\section{General discussion}

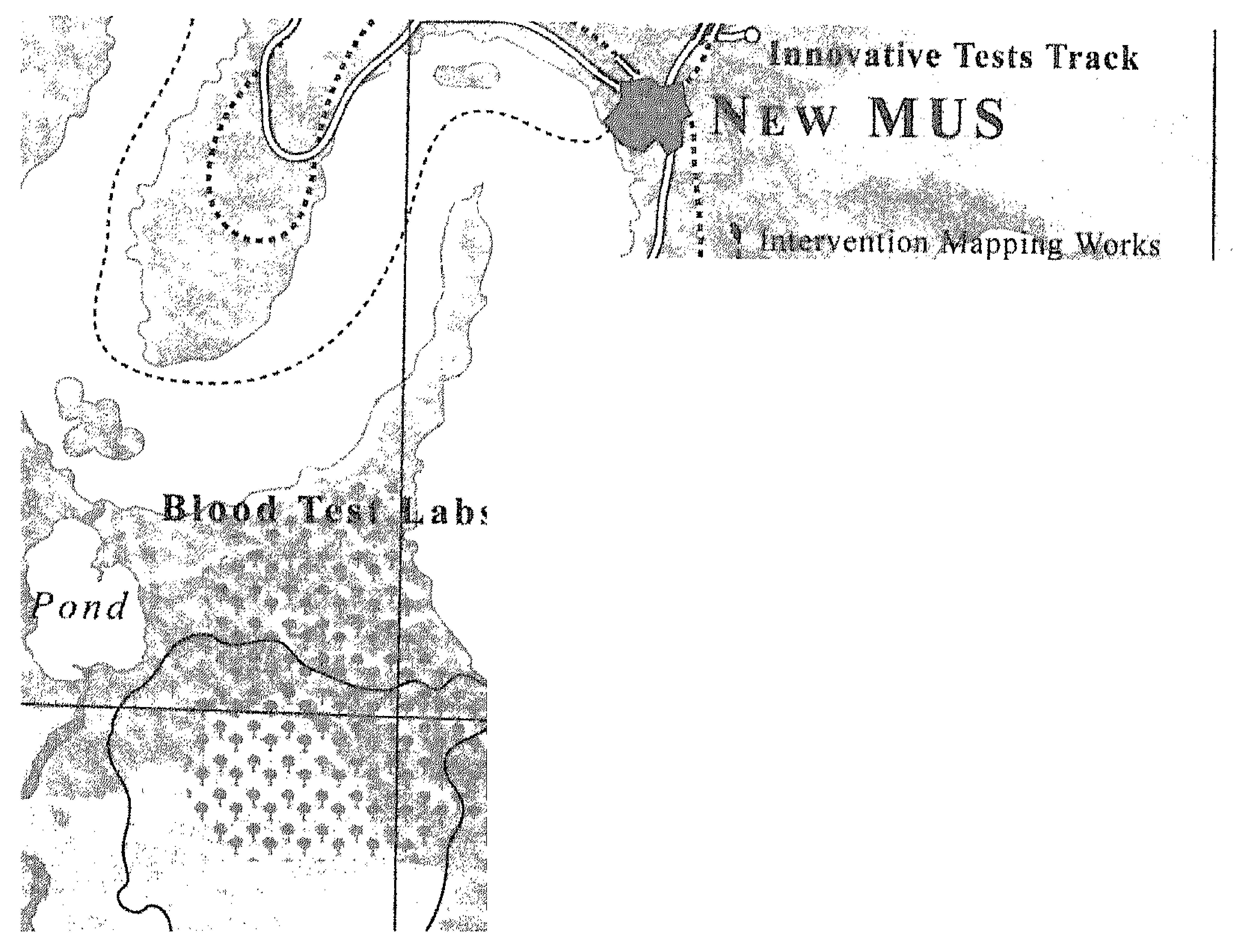


$186 \mid$ Chapter 12

\section{General discussion}

General practitioners (GPs) are frequently confronted with patients who present with complaints that remain unexplained after history taking and physical examination. In many cases, blood tests are ordered, even though their diagnostic yield is known to be limited, due to the high probability that complaints are self-limiting and the low prior chance of serious disease in this population. This thesis has evaluated watchful waiting as an alternative approach to immediate test ordering. In addition, it has focused on the systematic development and evaluation of a strategy to support GPs in the application of the watchful waiting approach.

In this chapter, the main findings of the studies are interpreted in the light of methodological issues. Three themes are discussed: the concept of unexplained complaints, the watchful waiting approach and our quality improvement strategy. The chapter ends with implications for daily practice, for future quality improvement programmes and for further research.

\section{Unexplained complaints}

This thesis has focused on unexplained complaints of recent origin. The five complaints that we selected for our randomised clinical trial were fatigue, abdominal complaints, weight changes, musculoskeletal complaints and itch. Patients with fatigue were most frequently included in the trial, while musculoskeletal complaints, e.g. non-specific low back pain or shoulder complaints, were much less frequently included. Although they are prevalent in general practice, their pathophysiological mechanism is often unclear. While we did not study the concept of unexplained complaints in this thesis, it was our impression that the unexplained character of the complaints only became a problem for GPs when there was also some sense of 'unease' or 'alarm'. From other research it had become clear that 'sense of alarm' and 'uncertainty' were linked, and triggered GPs to take further action to resolve the uneasy feelings $s^{1,2}$. Clear guidelines have been developed for non-specific low back pain and shoulder complaints, offering management suggestions using clinical pictures as a starting point instead of the pathophysiological mechanisms ${ }^{3,4}$. There is currently no such guideline in general practice for fatigue, however. As a consequence, when GPs are confronted with patients complaining about fatigue it is not clear whether they should perform diagnostic tests and if so, which tests they should perform, before they can initiate treatment. In addition, fatigue is an early symptom of several serious diseases, like diabetes mellitus and even malignancies. It is known from research into the 'sense of alarm' that GPs who get this feeling tend to search actively for clues to objectify it ${ }^{1}$. The determinants 
of the concept of 'unexplained complaints', and whether they vary between GPs or differ between patients and GPs, are still largely unknown.

As regards the patients who visit their GP with unexplained complaints, little is known about who will have self-limiting complaints and who will develop chronic complaints. When complaints become chronic, the burden of disease is considerable, in terms of patients' quality of life, health care use and absence from work due to illness ${ }^{5-7}$. Our data suggest that the quality of life of patients with unexplained complaints of recent origin is already low at an early stage, and this low quality of life tends to persist ${ }^{8,9}$. It therefore seems essential to take unexplained complaints seriously at an early stage, so that appropriate management can be started as soon as possible. One promising approach seems to be to explore the bearableness of the symptoms that are presented and explain their severity to patients. This may offer opportunities for better management, e.g. by switching the patients' and GPs' focus from 'finding a diagnosis' to 'improvement of daily functioning'. Our studies suggest that a mismatch between the GPs' and patients' views of the severity of the complaints may result in lower satisfaction and higher anxiety among patients ${ }^{10}$.

\section{Watchful waiting approach}

The robust design of a randomised clinical trial was used to evaluate the watchful waiting approach, taking into account not only diagnostic effects, which will be the subject of another thesis, and feasibility, but also non-diagnostic effects of testing, like satisfaction and costs.

\section{Effects}

Watchful waiting was found to be a feasible diagnostic approach in patients who present with unexplained complaints, and does not lead to testing at a later moment. Contrary to our hypothesis, watchful waiting did not have an unfavourable influence on patients' satisfaction with or anxiety after the consultation.

Costs of testing were, as expected, statistically significantly lower when a watchful waiting approach was applied. The differences in other health care related costs between an immediate test ordering approach and a watchful waiting approach were not statistically significant. However, the costs of diagnostics and therapy in the 12-month period after the initial consultation all had the same tendency towards higher costs in the immediate test ordering group. Although the overall difference in costs was not very high in absolute terms, the large numbers of patients with unexplained complaints may cause high overall costs of care if GPs frequently order tests immediately. An 
explanation for the higher costs after immediate test ordering might be that testing induced an iatrogenic test cascade due to false-positive test results, leading to further testing and, subsequently, treatments. Although we did not analyse this further the literature offers some evidence for such a phenomenon.

\section{GP and patient recruitment}

It proved difficult to recruit a sufficient number of GPs to participate in our randomised clinical trial evaluating the watchful waiting approach. Recruitment of GPs took place in a period in which GPs in the Netherlands were campaigning for better salaries. In addition, this recruitment period saw several other changes in Dutch primary health care, in which the GPs were investing a lot of time and effort, such as the introduction of practice nurses in general practice and the development of large-scale cooperative out-of-hours services. Many GPs were involved in these developments and stated that they lacked the time to participate in other activities.

The trial aimed to include 5000 patients, the number that was needed for the diagnostic study that was part of the trial but will be discussed elsewhere. Due to the low prevalence of serious pathology, many patients needed to be included to get a sufficient number of seriously diseased patients to calculate the diagnostic accuracies of tests. The total number of patients who actually participated in the study was 513. This number of patients was, however, sufficient to answer the questions discussed in this thesis, which concentrates on the feasibility of a watchful waiting approach. In the evaluation of the quality improvement strategy, the number of GPs is the critical factor. The 63 GPs who included patients in the trial were sufficient to allow meaningful conclusions on the watchful waiting approach and the quality improvement strategy.

GPs from each of the three groups included fewer patients than expected on the basis of prior research ${ }^{11}$. They experienced several difficulties and Lasagna's law fully held in this trial. Several risk factors for less successful patient recruitment were present in our trial, such as incident cases and GPs who had to remain alert during consultations and who were the first to inform the patients about the study ${ }^{12}$.

Most reasons given by GPs for not including patients were not likely to cause bias, e.g. 'forgot about the research study' or 'too busy'. However, some reasons that were mentioned may have caused bias. For instance, when a patient was considered eligible for inclusion, GPs sometimes reported that a few further questions yielded an explanation for the complaints after all. Other GPs reported that they were uncertain whether complaints were 'unexplained enough' to warrant the patient being included in the study. It is not easy to determine the direction of the bias due to these factors, nor is it possible to 
determine the effect of the limited patient inclusion on the generalisability of our conclusions.

The groups that were instructed to apply a watchful waiting approach, groups 2 and 3, may have had difficulties including patients, as it is known that some GPs feel empty-handed if they have no test or therapy to offer ${ }^{13}$. This may be even more true in the case of our trial, because there is no new test to offer as a reward for the efforts of participating in the trial.

The patients who were included in the trial were not evenly distributed among the three groups. GPs in the watchful waiting group without quality improvement strategy (group 2) included significantly fewer patients than those in the other two groups. This difference was caused by those GPs in this arm who did not include any patients at all. In terms of the background characteristics of the patients, there were no statistically significant differences between the groups. However, though patient inclusion was indeed lower in group 2 than in group 1 (immediate test ordering group) this was not the case in the 'watchful waiting with quality improvement strategy group' (group 3). Although this might be explained by the fact that the GPs in this group were supported by the quality improvement strategy, the analyses of the strategy actually showed a lack of effect. Participation in the third experimental arm may have caused better awareness of the trial and therefore better inclusion, as several GPs mentioned that it was difficult to remain aware of the trial while seeing patients.

We further analysed possible selective inclusion by trying to perform a noninclusion analysis. This was hardly possible, however, because 'unexplained complaints' had not been recorded as such by the GPs in the patients' records. Diagnoses at complaint level and the GPs' working hypotheses for participating patients were not useful either, because they reflected both explained and unexplained complaints.

One way to overcome the skewed distributions might have been randomisation at patient level instead of at practice level. In the context of the VAMPIRE study, this was not an option, however, because the quality improvement strategy was mainly carried out at practice level, which required analysis at the same level. In addition to this methodological argument, there was also a more fundamental argument, namely that it would be impossible for GPs to apply what they had learnt in the quality improvement strategy to one patient and ignore this knowledge for the next one.

In conclusion, although the distribution of patients over the groups was skewed, we have no indication that the inclusion was selective. However, we cannot entirely rule out selective inclusion either. 


\section{Quality improvement strategy}

As far as we know, this was the first time that the implementation in general practice of watchful waiting as a diagnostic strategy has been the subject of research. This section first discusses the problem analysis which preceded the development of the quality improvement strategy, and then evaluates the effects and development process of the strategy.

\section{Problem analysis}

The problem analysis included two topics: first, the dimensions of the problem of immediate blood test ordering when patients present with unexplained complaints, and secondly the barriers to and facilitators of test ordering behaviour. The problem analysis was based on literature research and qualitative studies.

\section{Health care problem associated with immediate test ordering}

The statement that immediate test ordering in cases of unexplained complaints is often superfluous has a sound theoretical base in Bayes' theorem and is supported by empirical evidence ${ }^{14-16}$. However, in retrospect, our analysis prior to the development of the quality improvement strategy was incomplete, as there was no strong evidence for the negative consequences of immediate test ordering, nor for the advantages of a watchful waiting approach. One study suggested that not all positive test results lead to further action, as GPs interpret these test results in the context of other factors, such as the reason for ordering a test ${ }^{17}$. Robust studies showing the effect of different test ordering approaches on the timely diagnosis of serious diseases were also lacking. As a result, despite the support from Bayes' theorem, it was hardly possible to convince the participants of the quality improvement strategy of the positive consequences of a watchful waiting approach.

Some data that were relevant for the development of the quality improvement strategy, such as the effects of watchful waiting on satisfaction, anxiety and costs, only became available after the strategy had been developed and tested. This was due to the design of the randomised clinical trial, which combined a research question on appropriate diagnosis and a question on quality improvement. However, performing the diagnostic study prior to the quality improvement study was not feasible, either in terms of research costs or in terms of patient and GP participation.

If future research manages to fill the gap in empirical evidence about the health care consequences of immediate test ordering, this may lead to two scenarios. The first is one in which watchful waiting remains superior to immediate test ordering, but GPs are not aware of this. In this case further quality 
improvement, focusing on problem awareness, is essential. The second scenario is one in which the negative consequences of immediate test ordering are limited and are not outweighed by the advantages of a watchful waiting approach. In this case, further quality improvement strategies to support watchful waiting become irrelevant and quality improvement needs to have a different focus.

\section{Barriers to and facilitators of a watchful waiting approach}

Dutch GPs have various reasons to order laboratory tests in situations of diagnostic uncertainty. The main aspects that the GPs in our study mentioned were: personal routines, tolerance of diagnostic uncertainty, perceived pressure on the part of a patient to order laboratory tests, time pressure and tactical motives, e.g. testing as a strategy to reassure a patient.

Our studies found that the GPs' estimation that their patients often expect to be tested proved correct. Explanations for these high expectations on the part of the patients include overestimations of the value of tests as a diagnostic tool: patients expect diagnostic certainty without mistakes. In addition, they see favourable results as a proof of good health and are confirmed in this belief by people in their social environment and the media. However, the patients' strong belief in laboratory testing did not seem to obstruct a watchful waiting approach; when GPs applied a watchful waiting approach, this did not reduce the patients' satisfaction with care.

Our study showed that testing for strategic reasons, such as prevention of referral or further diagnostic testing, does not have the intended effect. When tests were ordered immediately, this did not result in lower rates of referral or additional diagnostics compared to watchful waiting.

The studies reported on in this thesis did not evaluate the effects of a watchful waiting approach on two main barriers. The first barrier is the GPs' opinion that filling out a test ordering form takes much less time than discussing the limitations of test ordering with the patient ('time pressure'). Although very little is known about this topic from the literature, there is some evidence that practising a patient-centered communication style reduces the number of diagnostic tests ordered and thus improves efficiency ${ }^{18}$. Furthermore, although filling out a test-ordering form may provide short-term relief from pressure of time, when the results arrive, the interpretation and management require extra time. However, research in the field of behaviour change has shown that shortterm advantages of behaviour are more powerful in inducing change than longterm ones ${ }^{19}$.

The second barrier is the GPs' tolerance of uncertainty. It is known that this may influence GPs' management and it appears to be different between countries ${ }^{20,21}$. A special aspect that is often mentioned in this respect is the 
192

'sense of alarm' that according to GPs influences their behaviour'. So far, however, the diagnostic accuracy of such a 'sense of alarm' is unknown.

The research underlying the present thesis did not include 'external' barriers and facilitators. Retrospectively, they may be more important than we had expected from the results of our studies among GPs and patients. Currently, patients are receiving many signals that they may be suffering from diseases without knowing it, and that more examinations will improve their health. Some insurance companies reimburse check-ups, patient organisations offer tests and special clinics cater for specific target groups, e.g. elderly men with lower urinary tract symptoms or menopausal women, for extensive investigations and treatments ${ }^{22}$. This approach is called 'selling sickness' in marketing terminology. The fact that these external factors did not seem very important in our studies may be the result of a weakness in the method we used, because we interviewed GPs and patients. This design only allowed them to mention the topics that they were aware of. Influences they were not aware of, e.g. that of publicity, did not show up.

\section{Effect of quality improvement strategy on watchful waiting}

The quality improvement strategy did not improve the feasibility of a watchful waiting approach as compared to GPs merely receiving the instruction to postpone testing. Nor did the strategy influence the GPs' consultation-related performance, e.g. with respect to clarifying the reason for encounter or doing a physical examination. Finally, the patients' satisfaction about and anxiety after the consultation were not influenced by the quality improvement strategy either.

One of the explanations for the lack of effect of the quality improvement strategy may be that the feasibility of a watchful waiting approach was already good, so that the room for improvement was limited. Another explanation is that the systematic development of our quality improvement strategy, based on the findings of our problem analysis, was not done correctly. This is supported by the fact that our study found several of the most important problems to persist. GPs still felt pressured by the patients to order tests immediately, they continued to see mostly advantages from an immediate test ordering approach, and felt that it would take too much time and effort to change.

\section{Systematic development of the quality improvement strategy}

The studies reported on in this thesis show that the objectives we selected for the GPs' performance in daily practice (performance objectives) were correctly chosen. These objectives were: clarifying the reason for encounter, performing a physical examination, discussing a watchful waiting approach with the patient and asking the patient to return if the complaints do not disappear within a month. Exploring the reason for encounter may have a favourable effect on the 
patients' satisfaction and anxiety, because these proved to be related to the doctor-patient communication. Having GPs discuss test ordering also has a positive influence on patients' satisfaction.

However, the objectives for the quality improvement strategy itself (intervention objectives) proved not to be correct. For the GPs, the strategy focused on the actual process of changing test ordering behaviour, while the earlier stage of developing a sense of urgency to change had not yet been completed.

Although the focus for the patients was on the correct barriers, the intensity of the strategy seemed incorrect. Communicating the limitations of tests to patients is a very complex topic. Not only is the Bayesian test ordering theory rather difficult to understand, the message is also very different from the information patients usually get about test ordering, namely that there are new innovative test devices available and that more patients should be tested. Furthermore, the communication strategy most likely requires mass-medial and face-to-face strategies and repeated communication to get the message across. Chapter 3 mentions a dilemma that adds to the complexity of the topic. Since involving patients in the decision-making process is desirable, it is necessary for them to have some knowledge about the limitations of testing. However, the consequence of improved knowledge about the limitations of tests is that GPs can no longer use testing as a 'magic bullet' to reassure their patients. In spite of all the efforts this implies, it may nevertheless be worth while to invest in this approach. Apart from the arguments relating to testing in the case of unexplained complaints, patient education on test ordering may have a broader effect. More and more tests and testing facilities are currently becoming available directly to patients, without the involvement of health care professionals, or they are becoming available through commercial clinics. If the patients' knowledge about the possibilities and limitations of tests does not improve, they run the risk of being swamped by test results whose benefits for their health are questionable. This may, firstly, lead to high costs, which are unlikely to be outweighed by the benefits in terms of improved quality of life. And secondly, many patients will find it difficult to interpret positive or negative test results in the light of their symptoms. The results may even induce anxiety. Finally, the risk of false-positive results is expected to be relatively high and may lead to a cascade of further testing and treatments. It will be challenging to deliver the message about the limitations of the tests without decreasing patients' faith in health care.

The choice of theories to underpin our change strategy was intuitive, because the scientific basis of most theories is weak. For instance, the Stages of Change theory that we used in our quality improvement strategy was evaluated after our trial had ended, and it was found that the effects of interventions based on this theory were limited ${ }^{23}$. Evidence to support other theories that describe a stepwise change process is also limited ${ }^{24}$. Furthermore, no criteria are as yet 
available to make an evidence-based choice from among the available theories ${ }^{25}$.

In conclusion, the quality improvement strategy was not effective, but the systematic development and evaluation process produced new insights, which may be used to improve the strategy. This fits in with the idea that the development of complex interventions is an iterative process ${ }^{26,27}$.

\section{Implications}

\section{Implications for daily general practice}

The studies presented in this thesis show that proposing a watchful waiting approach when patients present with unexplained complaints is feasible and does not have an unfavourable influence on patient satisfaction or anxiety. It is especially when GPs order tests immediately for strategic reasons, such as to prevent specialist referral, or other, more expensive investigations, that they should reconsider their approach and try a watchful waiting approach more often.

Secondly, our findings show the importance of clarifying the patients' needs and requests relating to test ordering. GPs should explore their patients' expectations for further diagnostics, treatments and referrals. If patients expect these, it might be a signal that they are worried, and GPs could further explore if this is indeed the case. Furthermore, patients' requests could be a starting point for further explanation of the diagnostic possibilities and limitations of blood tests.

The third issue that GPs should explore is how patients experience their symptoms, as this may favourably influence patients' satisfaction and anxiety. The fourth issue that should be explored by GPs is their patients' quality of life, since an initially low quality of life tends to persist even if patients do not return to their GP for the symptoms with which they presented. Exploring these issues may enable GPs to more efficiently tailor the management of unexplained complaints to individual patients.

\section{Implications for future quality improvement programmes}

In attempts to further improve the diagnostic approach for patients with unexplained complaints, some questions should be given priority, such as: 'What are the effects of watchful waiting on the timely diagnosis of pathology?'; 'Do false-positive results indeed lead to a cascade of superfluous further testing and treatments? And if this is the case, what are the consequences?' and 'What 
are the differences in GPs' time investment per illness episode between a watchful waiting approach and an immediate test ordering approach?' Answers to these questions can help to design better strategies for improving test ordering.

Another useful step would be to explore specific 'external' barriers and facilitators, e.g. the influence of the media and the availability of tests that are not ordered by a GP. In addition, attention should be given to time investment and tolerance of uncertainty among GPs. The results of such explorations can also be used to enhance the quality improvement strategies.

Finally, in improving test ordering it is important to increase the GPs' problem awareness, by making any disadvantages of immediate test ordering visible. In addition, patients' knowledge about the value of diagnostic tests for unexplained complaints should be enhanced, and improvement efforts should take external barriers and facilitators, time investment and tolerance of uncertainty into account.

\section{Implications for further research topics}

Several research themes emerge from this thesis. First, the concept of unexplained complaints can be clarified further, in order to specify the aspects that are most difficult to deal with for GPs.

A second theme is the natural course of unexplained complaints. More knowledge is needed to determine at an early stage which complaints will become chronic and which will be self-limiting. This might allow the development of early interventions to prevent chronicity. The course of unexplained complaints will also be discussed in the other thesis.

A third theme is to clarify the consequences of false-negative and false-positive test results. Although the cascade of superfluous further testing and treatments that is thought to ensue from these results is frequently used as an argument to reduce test ordering rates, there is currently no evidence that this cascade does indeed exist.

A fourth aspect that requires attention is that of communicating the value of diagnostic tests to patients. We need to establish the arguments that can convince patients and find effective communication strategies. In addition, research is needed to determine the importance of tailoring the communication approach to different subgroups.

A fifth theme is the development of quality improvement strategies that focus on the efficiency of consultations and on the way GPs deal with uncertainty. An example of the latter is exploring the role of the GPs' 'sense of alarm' in their approach during consultations. 
$196 \mid$ Chapter 12

A final methodological theme is finding out what elements of the systematic development of quality improvement strategies are crucial to make them effective. Currently, most theories still await empirical support. 


\section{References}

1. Stolper CF, van Bokhoven MA, Houben $P$, van Royen $P$, van der Wiel $M$, van der Weijden $T$, et al. Gut feelings play a substantial role in General Practice. A study of definition and determinants. Submitted.

2. Stolper CF, van Royen P, van der Wiel M, Houben P, van Bokhoven MA, van der Weijden T, et al. Consensus on gut feelings in general practice. Submitted.

3. Chavannes A, Mens J, Koes B, Lubbers W, Ostelo R, Spinnewijn W, et al. NHG-Standaard Aspecifieke lagerugpijn. Huisarts Wet 2005;48:113-23.

4. Winters $J$, de Jongh $A$, Van der Windt $D$, Jonquière $M$, De Winter $A$, Van der Heijden $G$, et al. NHG-Standaard Schouderklachten. 1999 [cited 2007 November 20]; Available from: http://nhg.artsennet.nl/upload/104/standaarden/M08/start.htm

5. Katon WJ, Walker EA. Medically unexplained symptoms in primary care. J Clin Psychiatry 1998;59:2015-21.

6. Feder A, Olfson M, Gameroff M, Fuentes M, Shea S, Lantigua RA, Weissman MM I. Medically Unexplained Symptoms in an Urban General Medicine Practice. Psychosomatics 2001; 42:261-8.

7. Smith GR, Jr., Monson RA, Ray DC. Patients with multiple unexplained symptoms. Their characteristics, functional health, and health care utilization. Arch Intern Med 1986;146:69-72.

8. Koch $H$, van Bokhoven MA, ter Riet $G$, van der Weijden $T$, Dinant GJ, Bindels P. The course of unexplained complaints in general practice J Psychosomatic Research 2006;61:419.

9. Koch $H_{1}$ van Bokhoven MA, ter Riet $G$, van der Weijden $T$, Dinant $G J$, Bindels PJE. Demographic characteristics and quality-of-life of patients with unexplained complaints: a descriptive study in general practice. Qual Life Res 2007:16:1483-9.

10. Fransen GAJ, Janssen MJR, Muris JWM, Mesters I, Knottnerus JA. Measuring the severity of upper gastrointestinal complaints: does GP-assessment correspond with patients' selfassessment? Fam Pract 2007;24:252-8.

11. van der Weijden $T$, van Velsen $M$, Dinant $G J$, van Hasselt $C M$, Grol RPTM. Unexplained complaints in general practice. Prevaience, patients' expectations, and professionals' testordering behavior. Med Dec Making 2003;23:226-31.

12. van der Wouden JC, Blankenstein AH, Huibers $M J H$, van der Windt DAWM, Stalman WAB, Verhagen AP. Survey among 78 studies showed that Lasagna's law holds in Dutch primary care research. J Clin Epidemiol 2007;60:819-24.

13. van der Weijden $T$, van Bokhoven MA, Dinant GJ, van Hasselt CM, Grol RPTM. Understanding laboratory testing in diagnostic uncertainty: a qualitative study in general practice. Br J Gen Pract 2002;52:974-80.

14. DeKay ML, Asch DA. Is the defensive use of diagnostic tests good for patients, or bad? Med Dec Making 1998:18:19-28.

15. Owens DK. Defensive diagnostic testing- a case of stolen utility? Med Dec Making 1998;18:33-4.

16. Rovner DR. Laboratory testing may not glitter like gold. Med Dec Making 1998;18:23-3

17. Houben $P H H$, van der Weijden $T$, van Bokhoven MA, Droog AE, Winkens R, Grol RPTM. Overwegingen van huisartsen bij het interpreteren van uitslagen van laboratoriumonderzoek. Een kwalitatief onderzoek. Huisarts Wet 2005;48:326-32.

18. Stewart M, Brown J, Donner A, McWhinney I, Oates J, Weston W, et al. The impact of patientcentered care on outcomes. J Fam Pract 2000;49:796-804,

19. Baranowski T, Perry CL, Parcel GS. How individuals, environments, and health behavior interact. In: Glanz $\mathrm{K}$, Rimer B, Lewis $\mathrm{F}$, editors. Health Behavior and Health Education: Theory, Research, and Practice. San Francisco, California: Jossey-Bass; 2002:173.

20. Zaat JO, van Eijk JT. General practitioners' uncertainty, risk preference, and use of laboratory tests. Med Care 1992;30:846-54.

21. Grol $R$, Whitfield $M$, de Maeseneer J, Mokkink $H$. Attitudes to risk taking in medical decision making among British, Dutch and Belgian general practitioners Br J Gen Pract 1990;40:134-6. 
22. Nielen MMJ, Schellevis FG, Verheij RA. Evaluatie campagne 'Stop beginnende nierziekte'. Utrecht: NIVEL; 2007.

23. van Sluijs EMF, van Poppel MNM, van Mechelen $W$. Stage-based lifestyle interventions in primary care: Are they effective? Am J Prev Med 2004;26:330-43.

24. Riemsma RP, Pattenden J, Bridle C, Sowden AJ, Mather L, Watt IS, et al. Systematic review of the effectiveness of stage based interventions to promote smoking cessation. BMJ 2003 May 29, 2003;326:1175-7.

25. Greenhalgh $T$, Robert $G$, Macfarlane $F$, Bate $P$, Kyriakidou $O$. Diffusion of innovations in service organizations: systematic review and recommendations. Milbank Q 2004;82:581-629.

26. Bartholomew LK, Parcel GJ, Kok G, Gottlieb NH. Intervention mapping. Designing theory- and evidence-based health promotion programs. Mountain view, California, London, Toronto Mayfield publishing compagny; 2001.

27. Campbell NC, Murray E, Darbyshire J, Emery J, Farmer A, Griffiths $F$, et al. Designing and evaluating complex interventions to improve health care. BMJ 2007;334:455-9. 


\section{Summary}

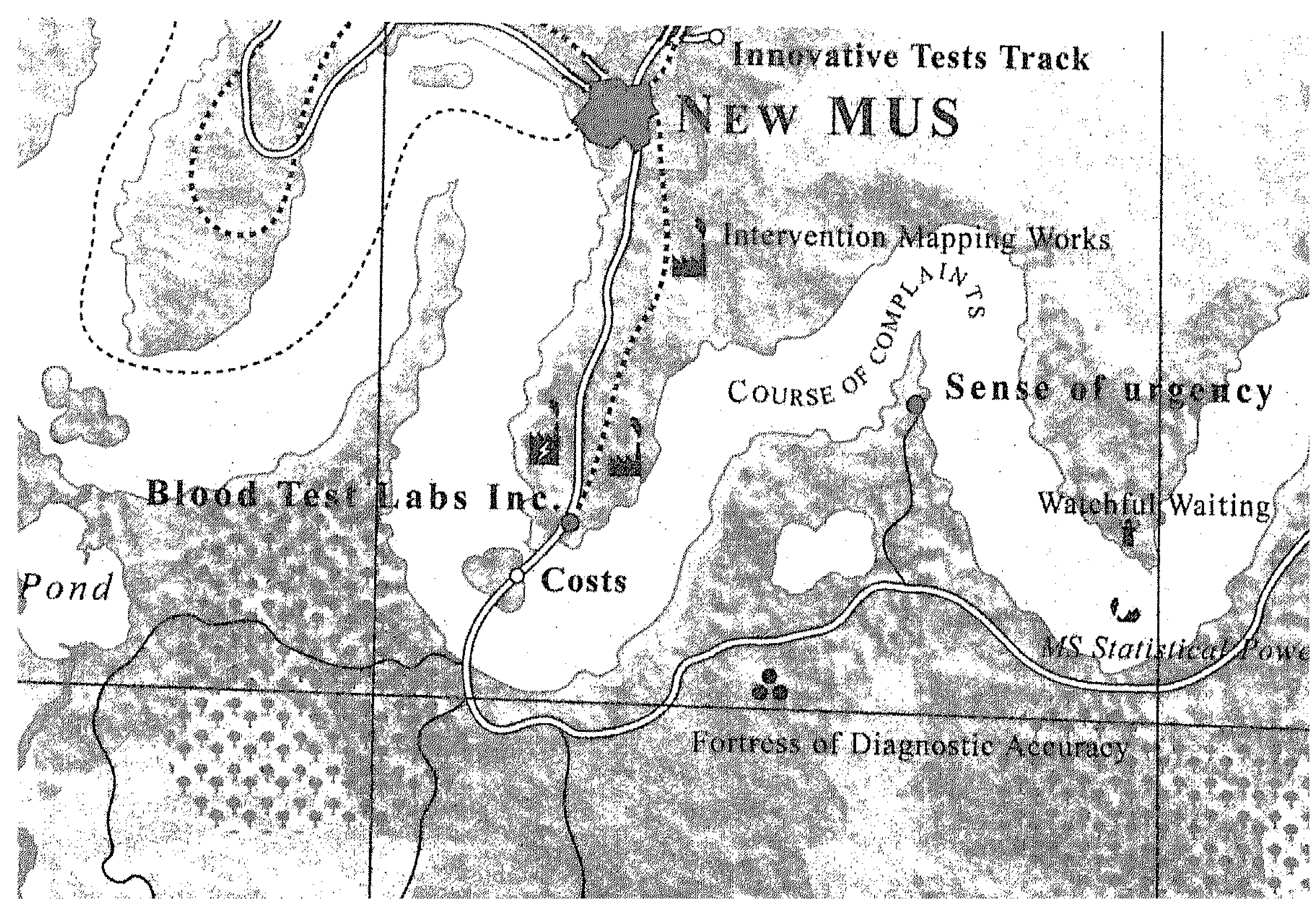




\section{Summary}

\section{Chapter 1}

Chapter 1 introduces the topic of the thesis. The aim of the research project reported on in this thesis was the systematic development and evaluation of a strategy to improve blood test ordering by means of a watchful waiting approach for patients who present to their general practitioner (GP) with unexplained complaints.

The chapter first discusses the various definitions and the relevance of 'unexplained complaints'. In the studies presented in this thesis, we used the 1998 definition of the Dutch College of General Practitioners (DCGP): 'Complaints for which the GP, after clarifying the reason for encounter, history taking and physical examination, is not able to establish a diagnosis'. Unexplained complaints are seen in $3-39 \%$ of patient contacts, and $90 \%$ of these complaints are self-limiting within a month.

The chapter then goes on to discuss the expected pros and cons of two approaches to the ordering of diagnostic blood tests, namely immediate test ordering and watchful waiting. Immediate test ordering carries a relatively high risk of false-positive test results, because the prevalence of serious pathology among patients with unexplained complaints is low. A watchful waiting approach was expected to lower both the number of patients to be tested and the risk of false-positive test results, without serious pathology being missed. We weighed up the pros and cons, while also taking into account the feasibility and acceptability for patients and GPs, satisfaction and anxiety among patients and costs of health care.

The third section of the chapter discusses the problem of GPs' test ordering performance in current care and ways to improve their test ordering behaviour. The literature on test ordering and decision-making theory suggests that test ordering by GPs is often superfluous. To improve this test ordering behaviour, we decided to develop a strategy in a systematic, theory-driven way.

These three issues were translated into the following research questions, which are addressed in this thesis:

1. What are the GP- and patient-related barriers and facilitators in the process of improving GPs' test ordering behaviour?

2. How can a quality improvement strategy to change GPs' test ordering behaviour for patients presenting with unexplained complaints be systematically developed?

3. What are the characteristics of patients presenting with unexplained complaints of recent origin in general practice?

4. What are the effects of a 4-week watchful waiting approach compared to immediate test ordering in patients presenting with unexplained complaints, 
in terms of feasibility, direct medical costs and patients' anxiety and satisfaction?

5. What is the effect of a systematically developed quality improvement strategy, compared to merely instructing GPs to postpone testing, on the GPs' test ordering behaviour?

6. What happens to the barriers and facilitators perceived by GPs during the process of changing their blood test ordering behaviour?

\section{Chapter 2}

This chapter aims to provide insight into the barriers and facilitators that GPs perceive in the context of ordering laboratory tests for patients who present with unexplained complaints. We investigated GPs' perception of barriers to and facilitators of test-ordering behaviour by means of semi-structured interviews with 21 GPs, based on surgery observations.

The study showed that Dutch GPs vary considerably in the motives underlying their test-ordering behaviour. The main motives for test ordering were: personal routines, intolerance of diagnostic uncertainty, pressure by the patient to perform laboratory testing (even if the patient does not explicitly ask for it), time pressure and tactical reasons for ordering tests.

The study concluded that the decision to request laboratory testing is the result of a complex interaction between often conflicting considerations and that a quality improvement strategy should focus on both medical and non-medical motives for test ordering.

\section{Chapter 3}

Chapter 3 discusses the expectations relating to blood test ordering from the perspective of the patients. Patients in the waiting rooms of general practices were asked by means of a questionnaire whether they wanted to be tested for their current complaints. Of the patients who answered this question affirmatively (26\%), 22 took part in qualitative interviews.

The GPs' perceptions of patient expectations proved to be justified: patients tend to overestimate the value of diagnostic testing, and expect diagnostic certainty without error and uncertainty. In addition, they regard favourable results as a proof of good health. Patients stated that they were confirmed in their ideas by people in their social environment and by the media. Many patients expected their GP to take an active test ordering approach, though some indicated that they might be convinced if their GP proposed a wait-andsee policy instead of immediately ordering tests.

The study shows the dilemma of whether it would be desirable to remove patients' misconceptions, allowing them to participate in policy decisions on the basis of sound information, or whether it would be preferable to leave the 
misconceptions uncontested, in order to retain the 'magic' of additional tests and reassure the patient. It is suggested that efforts by GPs to clarify the precise nature of patients' expectations may be helpful in creating a diagnostic strategy that satisfies both patients and GPs.

\section{Chapter 4}

This chapter addresses the methodology of systematically designing improvement strategies for quality of care. Since little was known about the best approach to develop quality improvement interventions when we started our study, we integrated several theories on quality improvement and change management. One method we particularly wanted to introduce and apply was 'Intervention Mapping', which derives from the field of health promotion. It describes the translation of knowledge about barriers to and facilitators of change into concrete intervention programmes for quality improvement. The design of a strategy to improve GPs' test ordering behaviour for patients with unexplained complaints is used here as an example, highlighting the decisions that have to be made during the process of designing a quality improvement intervention.

\section{Chapter 5}

A randomised clinical trial was set up to evaluate the effects of a watchful waiting approach instead of immediate blood test ordering when patients present with unexplained complaints in general practice. The trial had three main objectives: first, to determine the accuracy of blood tests in patients presenting with unexplained complaints, in terms of detecting pathology; secondly, to determine the value of a watchful waiting approach and thirdly to determine the effects of a quality improvement strategy in terms of promoting the postponement of blood test ordering by GPs for these patients. The protocol of the trial is presented in this chapter.

In the trial, general practices were randomised into three groups. Group 1 was instructed to order blood tests immediately, group 2 to apply a watchful waiting approach and group 3 also to postpone testing, but supported by the systematically developed quality improvement strategy. The following unexplained complaints were selected for inclusion: fatigue, abdominal complaints, musculoskeletal complaints, weight changes and itch. The diagnostic strategy to be used, involved both traditional and innovative tests. The quality improvement strategy consisted of two small-group meetings and a practice outreach visit. Patient follow-up ended 12 months after the initial consultation.

The innovative aspect of this trial was that it combined a clinical epidemiology study and a quality of care study. The first objective of the trial will be discussed 
in a parallel thesis by $\mathrm{H}$. Koch at the Academic Medical Center-University of Amsterdam.

\section{Chapter 6}

This chapter focuses on the demographic characteristics and quality-of-life of patients with early-stage unexplained complaints. While it is known that unexplained complaints, when they become chronic, lead to poor quality of life for patients and to high costs of care, little is known about the early stages of these complaints. Hence, demographic characteristics and quality-of-life scores were assessed in a descriptive study. Demographic characteristics were compared with those of a Dutch general practice population. Quality-of-life scores were determined with the RAND-36 and compared with those in another Dutch general practice population and with those of depressed patients.

The 63 GPs participating in the study included 513 patients with unexplained complaints. Data of 466 patients were analysed and showed that the majority of the patients with unexplained complaints of recent origin are educated women in their forties. Fatigue is their main reason for encounter, and they have a remarkably poor quality of life.

\section{Chapter 7}

This chapter reports some of the results of the randomised clinical trial that compared the feasibility of a watchful waiting approach with that of immediate test ordering. In addition, it determined the additional effect of the systematically developed quality improvement strategy on the feasibility of watchful waiting, and we also evaluated whether watchful waiting leads to more testing at a later moment.

The population consisted of 498 patients in the randomised clinical trial for whom data about the first consultation were available. They were included by 63 GPs. Immediate test ordering proved feasible in $92 \%$ of patients, whereas watchful waiting proved feasible in $84 \%$ of the patients in the group where GPs were supported by the quality improvement strategy and $86 \%$ of those in the group where GPs did not receive this support. The two watchful waiting groups did not differ significantly as regards the achievement of any of the GPs' performance objectives for performance in daily practice. Of the patients who returned after four weeks, none in the immediate test ordering group and six $(2 \%)$ in the two watchful waiting groups had tests ordered for them at this later stage.

In conclusion, watchful waiting is a feasible approach in patients presenting with unexplained complaints. 


\section{Chapter 8}

This chapter discusses the trial results that concern the patients' satisfaction with care and anxiety after the consultation. The same 498 patients and 63 GPs as in the previous chapter completed questionnaires about demographic characteristics, satisfaction with care, anxiety and aspects of the consultations (signs, symptoms and communication). In addition, laboratory test result forms were collected. The mean levels of satisfaction with and anxiety after the consultation (on a 10-point scale) were 7.3 and 3.1, respectively. These figures did not differ significantly between the three study groups. Factors relating to satisfaction and anxiety mainly concerned physician-patient communication, rather than the test ordering approach. Apparently, GPs underestimate how much they can contribute to the wellbeing of their patients by discussing their worries.

\section{Chapter 9}

In chapter 9 the costs of the different blood test ordering approaches are compared. The first question that was addressed concerned the differences in costs of blood test ordering between immediate test ordering and watchful waiting. The second question was whether patients in the watchful waiting group sought substitution of care through complementary medicine or over-thecounter (OTC) medication. Thirdly, we analysed whether the GPs in the watchful waiting group delivered different care as a substitute for test ordering, e.g. ordering $\mathrm{x}$-rays or referring to a hospital specialist. Finally, the differences in total direct costs of care between the two test ordering approaches were determined during a one year follow-up period. Like those in the previous two chapters, the analyses in this chapter are part of the randomised clinical trial whose protocol is described in chapter 5 .

The study confirmed the hypothesis that a watchful waiting approach would lead to lower costs of care. We could not confirm the GPs' assumption (see chapter 2) that immediate test ordering would be a substitute for more expensive diagnostic procedures, referrals or self-management. Patients did not seek substitution of care by purchasing OTC medication or visiting complementary therapists. Thus, from a financial point of view, watchful waiting is superior to immediate test ordering.

\section{Chapter 10}

In spite of a systematic development approach, the effects of quality improvement strategies are often limited. The change process itself largely remains a black box. In this chapter, the barriers and facilitators that GPs perceive during the change process are explored, to clarify some of the issues 
that play a role. For this purpose, we assessed the change process of all 24 GPs who participated in the quality improvement strategy arm of the randomised clinical trial, by means of in-depth interviews about barriers to and facilitators of change. Data were qualitatively analysed. Important themes identified in the interviews were lack of problem awareness, the time and effort it takes to change, the influence of patients and the pros and cons of the changed behaviour. The themes can be summarised into one comprehensive issue: the GPs lacked a sense of urgency to change. An important explanation seems to be that our problem analysis prior to the development of the quality improvement strategy had been insufficient. The analysis failed to make it clear whether the theoretical disadvantages of immediate blood test ordering did indeed cause health or care problems in daily general practice, and if they did, the problems were not visible to GPs. As a result, insufficient attention was given in the strategy to applicability issues, such as time investment and costs. Clarity about these issues seems a prerequisite for an effective quality improvement strategy.

\section{Chapter 11}

Chapter 11 describes the obstacles and challenges of diagnostic research among patients who present with unexplained complaints in general practice. The origin of several difficulties is the concept of unexplained complaints itself, which is not unequivocally defined. As a consequence, it becomes difficult to select the proper study population, to define accurate reference standards and to define useful outcome measures. Although several of the individual obstacles have been addressed in research on other complaints as well, in our opinion their combination is characteristic of unexplained complaints. This might be one of the reasons why such research has been sparse and why there is a need for more adequate methodology.

\section{Chapter 12}

Chapter 12 discusses the findings from the previous chapters in a broader context. The first issue is the concept of unexplained complaints. The studies reported on in this thesis give the impression that unexplained complaints only become a problem for GPs if they cause a 'sense of alarm', but a lot more evidence about the determinants of the concept is still needed.

The poor quality of life of patients that we found in the early course of the complaints underlines the fact that they need to be taken seriously, so that the appropriate management can be started as soon as possible.

The second issue that is discussed is the watchful waiting approach, which we found to be feasible and to lead to lower costs than an immediate test ordering approach. 
We studied the use of a watchful waiting approach by means of a randomised clinical trial design. However, it proved to be impossible for GPs to include enough patients in the trial, although this was not a problem for the studies presented in this thesis. In addition, there was a skewed distribution of patients over the three groups, with fewer patients in the watchful waiting group (group 2) than in the other groups. This was due to a higher number of GPs in group 2 who included no patients at all, as compared to the other two groups. Our analyses found no signs of selective inclusion, however.

The third issue is the support that we tried to give to GPs in applying a watchful waiting approach, by means of a quality improvement strategy. It turned out that the problem analysis on which our quality improvement strategy was based was incomplete, which may explain the lack of effect of the strategy. Although the objectives we had established for GP performance in daily practice proved to be correct, future quality improvement strategies will need to enhance the GPs' awareness of the negative effects of immediate test ordering. In addition, the limitations of tests need to be communicated to patients. This complex topic is not only relevant to patients with unexplained complaints. Since more and more testing facilities are becoming available directly to patients, they run the risk of being swamped by test results whose benefits for their health are questionable. More knowledge about the possibilities and limitations of tests would enable them to make an informed choice.

Finally, the implications of the studies are discussed. The implications for daily general practice relate particularly to doctor-patient communication, while the implications for further quality improvement programmes relate especially to the problem analysis. The themes for further research that emerge from the studies firstly concern the concept and course of unexplained complaints. Secondly, the consequences of false-positive and false-negative results and the communication of these consequences to GPs and patients need clarification. A third theme is the development of strategies that may improve the GPs' efficiency during consultations and the way they deal with uncertainty. Finally, evidence needs to be gathered about those elements of systematic development of quality improvement strategies that are crucial to their effectiveness. 


\section{Samenvatting}

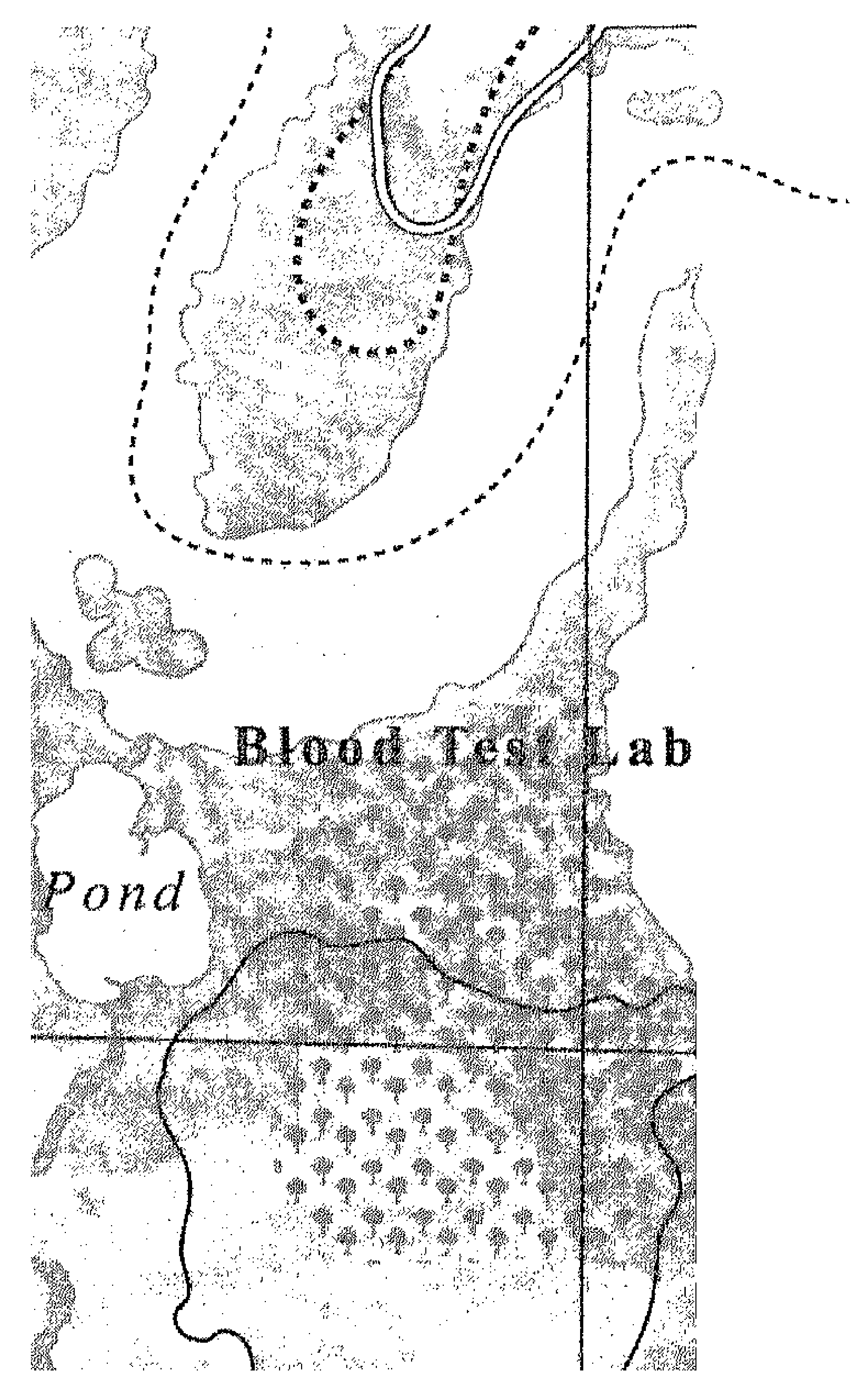




\section{Samenvatting}

\section{Hoofdstuk 1}

Hoofdstuk 1 is de inleiding van het proefschrift. Het doel van de onderzoeken in dit proefschrift is om het aanvragen van bloedonderzoek bij patiënten die met onbegrepen klachten op het spreekuur van de huisarts komen te verbeteren. Daartoe wordt het direct aanvragen van bloedonderzoek vergeleken met een afwachtend beleid. Ter ondersteuning van het afwachtende beleid wordt op systematische wijze een interventie ontwikkeld.

Allereerst worden in dit hoofdstuk de verschillende definities en de relevantie van het begrip 'onbegrepen klachten' besproken. In dit proefschrift gebruiken we de definitie van het Nederlands Huisartsen Genootschap: 'Klachten waarbij de huisarts, na adequate vraagverheldering, anamnese en lichamelijk onderzoek, niet in staat is een diagnose te stellen'. In de huisartsenpraktijk is in $3-39 \%$ van de contacten sprake van onbegrepen klachten. Van deze klachten lijkt $90 \%$ binnen een maand vanzelf over te gaan.

Vervolgens worden de verwachte voor- en nadelen besproken van zowel direct aanvragen als een afwachtend beleid. Direct aanvragen van bloedonderzoek bij onbegrepen klachten heeft een relatief groot risico dat uitslagen ten onrechte afwijkend zijn (fout-positief). Dat komt omdat de kans dat een patiënt een ernstige ziekte heeft die je met bloedonderzoek zou kunnen opsporen erg klein is, naar schatting $2 \%$. Aangezien zelfs de beste tests ieder een kans van $5 \%$ hebben dat de uitslag ten onrechte afwijkend is, is de kans op ten onrechte afwijkende uitslagen groter dan de kans op een terecht afwijkende uitslag. Aan de uitslag zelf kan de huisarts niet zien of deze terecht is of niet. Als gevolg daarvan wordt mogelijk ten onrechte verder onderzoek of behandeling ingezet. Bovendien kan de patiënt ongerust worden van de uitslag. Als eerst een paar weken wordt afgewacht, zullen de meeste klachten vanzelf verdwijnen, waardoor na de periode van afwachten minder mensen hoeven te worden getest. Bovendien heeft het ziektebeeld zich mogelijk wat verder ontwikkeld, waardoor het ook beter is op te sporen met bloedonderzoek. Naar verwachting worden, door het afwachtende beleid, geen extra patiënten met ernstige ziekten gemist of te laat opgespoord. Bij het afwegen van de voor- en nadelen moet ook rekening gehouden worden met de vraag of het beleid haalbaar en acceptabel is voor patiënten en huisartsen. Bovendien moeten de ongerustheid en tevredenheid van patiënten over de geleverde zorg worden meegewogen. Tenslotte kunnen de kosten van de twee diagnostische benaderingen onderling verschillen.

Na de voor- en nadelen wordt besproken wat de problemen zijn van het huidige aanvraaggedrag van huisartsen en hoe dit kan worden verbeterd. Uit de wetenschappelijke literatuur over het aanvragen van diagnostische tests en de 
interpretatie daarvan, kan men concluderen dat huisartsen regelmatig teveel tests aanvragen. Om dat te verbeteren, moet een interventie worden ontwikkeld op een systematische en theoretisch onderbouwde wijze.

\section{Hoofdstuk 2}

Dit hoofdstuk heeft als doel om inzicht te krijgen in de factoren bij huisartsen die het aanvragen van laboratoriumonderzoek bij patiënten met onbegrepen klachten bevorderen of belemmeren. Om dit doel te bereiken heeft een onderzoeker spreekuren bijgewoond. Vervolgens heeft zij semi-gestructureerde interviews afgenomen bij 21 huisartsen. De patiënten die op het spreekuur waren geweest, vormden het vertrekpunt om de door de huisarts ervaren bevorderende en belemmerende factoren te inventariseren.

Het onderzoek laat zien dat Nederlandse huisartsen onderling sterk verschillen in de redenen waarom zij diagnostiek aanvragen. Hun belangrijkste redenen zijn: persoonlijke routines, mate van tolerantie voor diagnostische onzekerheid, druk van de patiënt om laboratoriumonderzoek te doen (ook al vraagt de patiënt daar niet altijd expliciet om), tijdsdruk en tactische redenen om onderzoek aan te vragen. Een voorbeeld van dat laatste is voorstellen om eerst bloedonderzoek te doen bij een patiënt die vraagt om een verwijzing naar een specialist.

De conclusie van dit onderzoek is dat de beslissing om laboratorium onderzoek aan te vragen het resultaat is van verschillende overwegingen die elkaar beïnvloeden en soms tegenstrijdig zijn. Het hoofdstuk eindigt met het advies om een interventie die het aanvraaggedrag moet verbeteren, te baseren op de bevorderende en belemmerende factoren.

\section{Hoofdstuk 3}

In hoofdstuk 3 worden de verwachtingen van patiënten ten aanzien van bloedonderzoek geïnventariseerd. Allereerst vulden patiënten in de wachtkamer van de huisartsenpraktijk op een vragenlijst in of zij voor hun huidige klachten bloedonderzoek wensten. Van de patiënten die deze vraag bevestigend beantwoordden $(26 \%)$, werden er 22 geïnterviewd.

Het idee van huisartsen dat patiënten vaak bloedonderzoek willen, bleek te kloppen. Patiënten hebben de neiging om de diagnostische mogelijkheden van tests te overschatten. Ze verwachten dat de uitslag zekerheid geeft over de aan- of afwezigheid van ziekte, zonder fouten of een marge van onzekerheid. Bovendien zien ze niet-afwijkende uitslagen als een bewijs van goede gezondheid. Patiënten geven aan dat zij in hun visie worden gesteund door mensen in hun sociale omgeving en door de media. Veel patiënten verwachten dat hun huisarts een aktieve diagnostische benadering kiest, hoewel sommigen 
aangeven dat de huisarts hun misschien zou kunnen overtuigen, als hij of zij een afwachtend beleid zou voorstellen.

Dit onderzoek laat een dilemma zien. Enerzijds zouden de misvattingen van patiënten moeten worden gecorrigeerd, om hen de kans te geven om mee te kunnen beslissen over het te voeren beleid. Anderzijds zorgt het grote vertrouwen van patiënten in tests ervoor dat huisartsen diagnostiek kunnen gebruiken als 'magisch' instrument dat zekerheid geeft over de aan- of afwezigheid van ziekte en op die manier de patiënt kunnen geruststellen.

Aan het einde van het hoofdstuk wordt aangegeven dat het verhelderen van de verwachtingen en hulpvraag van de patiënt door de huisarts, zou kunnen helpen bij het kiezen voor een diagnostische benadering die zowel de patiënten als de huisartsen tevreden stelt.

\section{Hoofdstuk 4}

In dit hoofdstuk wordt de methodologie beschreven van het op systematische wijze ontwikkelen van interventies om de kwaliteit van zorg te verbeteren. Tot nu toe was de kennis over dit onderwerp tamelijk fragmentarisch. In dit hoofdstuk worden verschillende theorieën over het verbeteren van kwaliteit en het sturen van verandering geïntegreerd. Eén methode in het bijzonder, afkomstig uit de gezondheidsvoorlichting: 'Intervention Mapping' wordt geïntroduceerd en toegepast. De methode beschrijft hoe kennis over de bevorderende en belemmerende factoren kan worden vertaald in een concreet programma voor kwaliteitsverbetering. Het ontwerpen van een interventie om het aanvraaggedrag van huisartsen te verbeteren, als zij patiënten op hun spreekuur zien met onbegrepen klachten, wordt gebruikt als voorbeeld. Het voordeel van de beschreven methode is dat de beslissingen die tijdens het ontwerpproces van de interventie moeten worden genomen, zichtbaar worden gemaakt.

\section{Hoofdstuk 5}

Om bij patiënten met onbegrepen klachten de effecten van een afwachtend beleid te kunnen vergelijken met de effecten van het direct aanvragen van bloedonderzoek, hebben we een gerandomiseerd klinische onderzoek opgezet. Het protocol van dit onderzoek wordt in dit hoofdstuk samengevat. Het onderzoek heeft drie belangrijke doelen: (1) het bepalen van de diagnostische precisie van bloedtests ten aanzien van het opsporen van ziekte; (2) het bepalen van de effecten van een afwachtend beleid en (3) het bepalen van de effecten van een interventie die de kwaliteit van het aanvragen van bloedtests door huisartsen kan verbeteren, door het stimuleren van een afwachtend beleid. Het eerste en gedeeltelijk ook het tweede doel wordt besproken in een ander 
proefschrift, dat wordt geschreven door $\mathrm{H}$. Koch van het Academisch Medisch Centrum-Universiteit van Amsterdam.

In het onderzoek worden huisartsenpraktijken door loting verdeeld over drie groepen. Huisartsen uit groep 1 krijgen de opdracht om, bij patiënten die komen met onbegrepen klachten, direct bloedonderzoek aan te vragen. Groep 2 krijgt de opdracht om voor te stellen vier weken af te wachten en groep $3 \mathrm{krijgt}$ dezelfde opdracht als groep 2 maar wordt daarbij ondersteund door de systematisch ontwikkelde interventie. Patiënten met de volgende onbegrepen klachten kunnen deelnemen: moeheid, buikklachten, spier- en gewrichtsklachten, gewichtsverandering en jeuk. De interventie voor de huisartsen uit groep 3 bestaat uit twee bijeenkomsten in kleine groepen en een bezoek aan de praktijk voor individuele adviezen. $\mathrm{Na}$ het begin van de deelname aan het onderzoek wordt het beloop van de klachten van de deelnemende patiënten nog 12 maanden gevolgd.

Het bijzondere van dit onderzoek is dat een diagnostische vraagstelling en een kwaliteit van zorg vraagstelling worden gecombineerd in één onderzoek.

\section{Hoofdstuk 6}

De demografische kenmerken en kwaliteit van leven van patiënten met beginnende onbegrepen klachten zijn het onderwerp van dit hoofdstuk. Het is bekend dat onbegrepen klachten, als ze chronisch worden, kunnen leiden tot een slechte kwaliteit van leven en tot hoge kosten in de gezondheidszorg. Of dit ook geldt voor de vroege fase van onbegrepen klachten, is echter niet bekend. Daarom hebben we vragen over de demografische kenmerken en kwaliteit van leven gesteld aan 513 patiënten van 63 huisartsen. Voor het bepalen van de kwaliteit van leven gebruiken we een bestaand meetinstrument, de RAND-36 vragenlijst. De demografische kenmerken worden vergeleken met algemene gegevens over patiënten in Nederlandse huisartsenpraktijken. De kwaliteit van leven scores worden vergeleken met een andere steekproef uit de Nederlandse huisartsenpraktijken en ook met scores van depressieve patiënten.

Van 466 patiënten waren er voldoende gegevens om te analyseren. Deze laten zien dat de meeste mensen met beginnende onbegrepen klachten hoger opgeleide vrouwen van tussen de 40 en 50 jaar zijn. Het vaakst komen zij met moeheid en zij hebben een opvallend slechte gezondheid, in vergelijking tot andere patiënten.

\section{Hoofdstuk 7}

Dit is het eerste van drie hoofdstukken in het proefschrift, waarin de resultaten van het gerandomiseerde klinische onderzoek uit hoofdstuk 5 worden gerapporteerd. In dit hoofdstuk worden de haalbaarheid van een afwachtend beleid in vergelijking tot het direct aanvragen van bloedonderzoek en de 
toegevoegde waarde van de interventie daarbij vergeleken. Bovendien bekijken we of het voeren van een afwachtend beleid leidt tot het aanvragen van tests op een later tijdstip.

Van 498 patiënten, uit de praktijken van 63 huisartsen, zijn gegevens beschikbaar over het eerste consult. Deze worden gebruikt voor de analyses.

Direct aanvragen van bloedonderzoek blijkt haalbaar in $92 \%$ van de gevallen; het voeren van een afwachtend beleid in $84 \%$ en $86 \%$ voor respectievelijk de groepen met en zonder ondersteuning van de interventie. Vooraf hadden we doelen opgesteld ten aanzien van de gewenste consultvoering in de praktijk. De twee groepen met een afwachtend beleid verschillen onderling niet significant in de mate waarin ze het gewenste gedrag uitvoeren. Van de patiënten die na vier weken terugkwamen op het spreekuur, werd bij niemand uit de direct aanvragen groep bloedonderzoek aangevraagd en bij zes patiënten uit de twee groepen met een afwachtend beleid. Concluderend, een afwachtend beleid is haalbaar bij patiënten met onbegrepen
klachten.

\section{Hoofdstuk 8}

In dit hoofdstuk worden de resultaten van het gerandomiseerde onderzoek over de tevredenheid van patiënten met de geleverde zorg en de ongerustheid van patiënten na het consult besproken. Dezelfde 498 patiënten, van 63 huisartsen, als in het vorige hoofdstuk beantwoordden vragen over hun tevredenheid, ongerustheid en aspecten van de consulten bij de huisarts (symptomen, afwijkingen bij lichamelijk onderzoek en het verloop van de arts-patiënt communicatie). Daarnaast verzamelden we kopieën van de formulieren met testuitslagen.

De gemiddelde tevredenheid met en ongerustheid na het consult (op een 10-puntsschaal) waren respectievelijk 7,3 en 3,1. Factoren die de tevredenheid en ongerustheid beïnvloedden, betroffen vooral de arts-patiënt communicatie in plaats van het al dan niet aanvragen van bloedonderzoek. Blijkbaar onderschatten huisartsen hoeveel ze kunnen bijdragen aan het welzijn van hun patiënten door hun zorgen te bespreken.

\section{Hoofdstuk 9}

In hoofdstuk 9 worden de verschillen in kosten tussen het direct aanvragen van bloedonderzoek en het voeren van een afwachten beleid vergeleken. De eerste vraag is of er verschillen zijn in de kosten van de aangevraagde bloedtests. De tweede vraag is of patiënten uit de groep met een afwachtend beleid zoeken naar plaatsvervangende vormen van zorg via complementaire geneeswijzen of vrij verkrijgbare zelfzorg medicijnen. Ten derde hebben we geanalyseerd of de huisartsen alternatieve zorg boden in plaats van bloedtests, bijvoorbeeld door 
een röntgenfoto aan te vragen of de patiënt te verwijzen naar een specialist in het ziekenhuis. Tenslotte hebben we gekeken naar verschillen in kosten van zorg gedurende de periode van een jaar na het eerste consult met onbegrepen klachten van de patiënt. De analyses in dit hoofdstuk zijn, net als die in de vorige twee hoofdstukken, onderdeel van het gerandomiseerde onderzoek, waarvan het protocol is beschreven in hoofdstuk 5 .

Het onderzoek toont aan dat de verwachting dat een afwachtend beleid leidt tot lagere testkosten klopt. Hetzelfde lijkt te gelden voor de kosten van gezondheidszorg, al kunnen we dat op basis van deze gegevens niet met zekerheid zeggen. Daarnaast toont het onderzoek aan dat het idee van huisartsen, dat bloedonderzoek het gebruik kan voorkòmen van andere vormen van zorg, zoals verwijzing naar een specialist of dure diagnostische tests, niet klopt. Bovendien blijken patiënten die het advies krijgen van hun huisarts om even af te wachten niet vaker zelfzorg geneesmiddelen te kopen of naar een complementaire genezer te gaan dan patiënten bij wie direct bloedonderzoek wordt aangevraagd. Vanuit een financieel perspectief is afwachten dan ook superieur aan direct bloedonderzoek aanvragen.

\section{Hoofdstuk 10}

Zelfs als ze op een systematische manier worden ontwikkeld, blijkt het effect van interventies die gericht zijn op de verbetering van de kwaliteit zorg, vaak beperkt. Het veranderingsproces zelf blijft grotendeels onopgehelderd. In dit hoofdstuk worden de bevorderende en belemmerende factoren geïnventariseerd die huisartsen ervaren tijdens hun proces van gedragsverandering. Op die manier willen we inzicht krijgen in de elementen die tijdens dit proces een rol spelen. Voor dit doel werd bij alle 24 huisartsen uit het gerandomiseerde onderzoek die deelnamen aan de interventie ter ondersteuning van hun afwachtende beleid (groep 3) een diepte-interview afgenomen over hun bevorderende en belemmerende factoren. Deze interviews vonden plaats enige tijd nadat ze de twee bijeenkomsten hadden bijgewoond. Belangrijke knelpunten die uit het onderzoek naar voren kwamen, waren: het gebrek aan besef dat direct aanvragen leidt tot problemen, de tijd en moeite die het kost om te veranderen, de invloed van patiënten en de nadelen van het vaker adviseren van een afwachtend beleid. In één thema samengevat: de huisartsen zien de noodzaak tot verandering niet. Een belangrijke verklaring lijkt te zijn dat de probleemanalyse (de beschrijving in maat en getal van het gezondheidsprobleem dat moet worden verbeterd) die voorafging aan het ontwikkelen van de strategie, onvoldoende was. Er was vooraf niet aangetoond dat de theoretische nadelen van direct bloedonderzoek doen, zoals ze ook in de inleiding zijn beschreven, in de praktijk daadwerkelijk leiden tot gezondheidsproblemen bij patiënten. Als de gezondheidsproblemen optreden, zijn ze in 
ieder geval niet zichtbaar voor de huisartsen. Als gevolg van deze ontbrekende informatie, is bij het ontwikkelen van de interventie onvoldoende aandacht besteed aan de toepasbaarheid van het afwachtend beleid, zoals de tijdsinvestering die dit vraagt, de kosten en de tevredenheid en ongerustheid van huisartsen en patiënten. Een beter inzicht in de problemen van een afwachtend beleid in de dagelijkse praktijk lijkt een noodzakelijke voorwaarde voor het ontwikkelen van een effectieve interventie.

\section{Hoofdstuk 11}

Hoofdstuk 11 beschrijft de uitdagingen in diagnostisch wetenschappelijk onderzoek naar onbegrepen klachten in de huisartsenpraktijk. De oorsprong van verschillende methodologische moeilijkheden is het fenomeen 'onbegrepen klachten' zelf, omdat het begrip niet eenduidig is gedefinieerd. Dit probleem is de oorsprong van drie andere methodologische problemen: het selecteren van de juiste deelnemers, het definiëren van een goede 'gouden standaard' (test die een aandoening met zekerheid kan aantonen en die kan worden gebruikt om een nieuwe test mee te vergelijken), en het kiezen van goede uitkomstmaten. Deze problemen kunnen individueel ook een rol spelen bij andere onderzoeken, maar naar onze mening is de combinatie typisch voor onbegrepen klachten. Mogelijk is dat één van de redenen waarom weinig onderzoek wordt gedaan naar onbegrepen klachten. Het maakt in ieder geval dat er behoefte is aan de ontwikkeling van geschikte onderzoeksmethoden.

\section{Hoofdstuk 12}

In hoofdstuk 12 worden eerst de belangrijkste bevindingen uit het proefschrift samengevat en geïnterpreteerd. Vervolgens worden de methodologisch sterke en zwakke punten en de verdere implicaties besproken. Het belangrijkste methodologische thema is dat er veel minder patiënten dan gepland deelnamen aan het onderzoek en dat deze bovendien niet gelijkmatig over de groepen waren verdeeld. Groep 2 had veel minder patiënten dan de andere twee groepen. Het lage aantal deelnemers is geen probleem in de onderzoeken in dit proefschrift. De ongelijkmatige verdeling lijkt niet te berusten op een systematische selectie. Dit kunnen we echter niet wetenschappelijk bewijzen, aangezien het niet goed mogelijk is om onderzoek te doen naar de patiënten niet hebben deelgenomen aan het onderzoek.

In het hoofdstuk wordt aanbevolen om in de toekomst meer aandacht te besteden aan de probleemanalyse die voorafgaat aan de ontwikkeling van een nieuwe interventie,

Het hoofdstuk eindigt met aanbevelingen voor de dagelijkse huisartsenpraktijk, voor verdere kwaliteitsverbetering, voor de ontwikkeling van onderzoeksmetho- 
dologie en voor verder onderzoek. Voor de dagelijkse praktijk worden aanbevelingen gegeven om de arts-patiënt communicatie te verbeteren, met name door betere verheldering van de vragen en verwachtingen van de patiënt. Toekomstige interventies om de kwaliteit van zorg bij onbegrepen klachten te verbeteren, zouden moeten worden aangepast aan de bevindingen uit de probleemanalyse. Bovendien zouden ze zich meer moeten richten op de misvattingen van patiënten ten aanzien van de diagnostische mogelijkheden en beperkingen van tests. Aangezien steeds meer test mogelijkheden beschikbaar komen voor patiënten, is het belangrijk dat zij in staat zijn om zelf geïnformeerde keuzes te maken uit het aanbod. Aanbevelingen voor verder onderzoek, voor zover niet besproken in hoofdstuk 11, concentreren zich op het verbeteren van de deelname van patiënten. In de toekomst is er nog genoeg onderzoek te doen, op alle hierboven genoemde gebieden. 


\section{Publications}

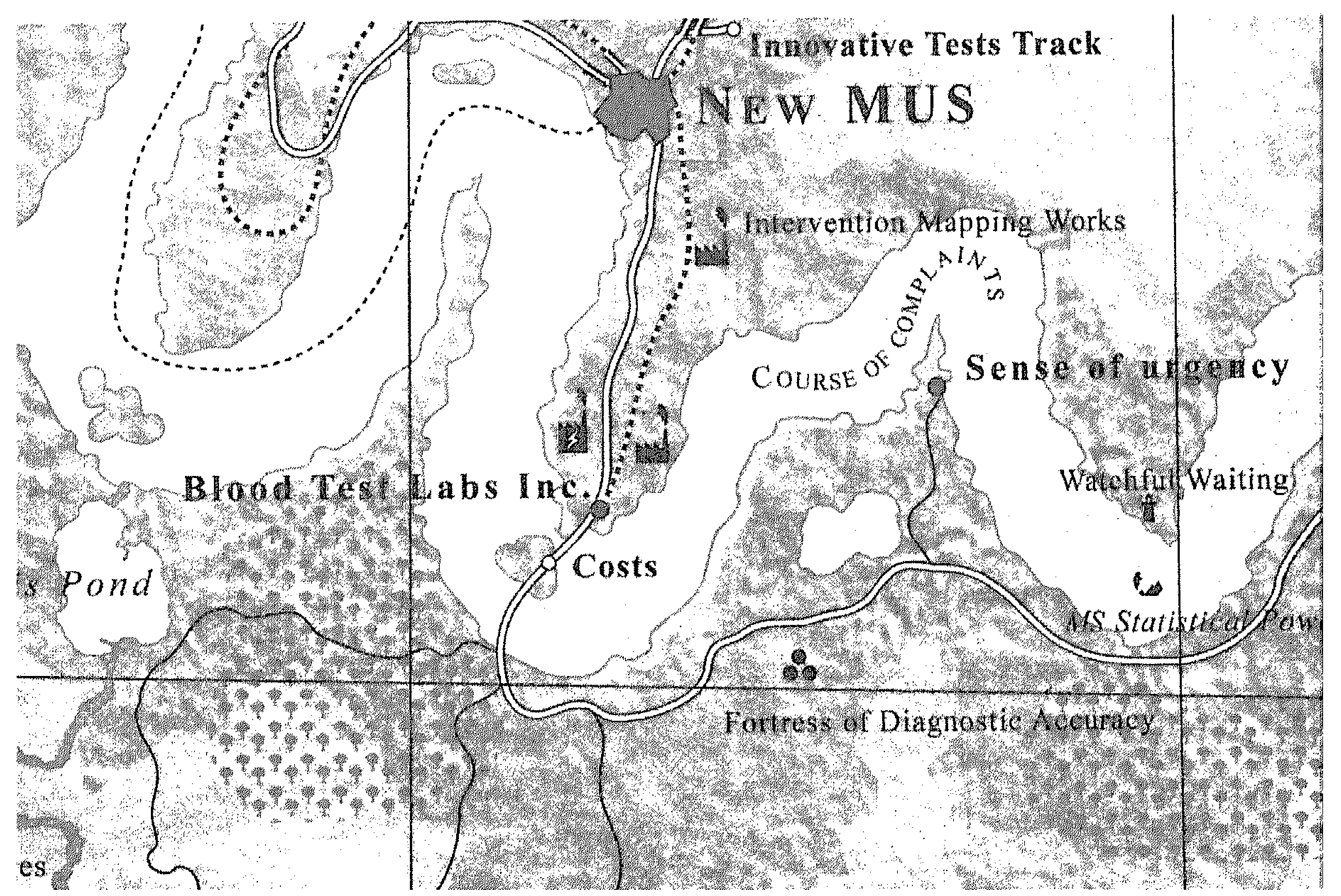




\section{Publications}

\section{Papers}

van Bokhoven MA, van Dalen J, Metsemakers JFM, van Enckevort C. The Maastricht Adoption Programme in General Practice: The Students' View. Education for Health Change in training \& practice. 1998;11:57-64

van Bokhoven MA, Verhoeven BH, Scherpbier AJJA, Kerkhofs E, van Gerwen ALEM, van Luijk SJ, van der Vleuten CPM. De relatie tussen aanwezigheid tijdens vaardigheidstrainingen en studieresultaten: een cohortstudie. Bulletin Medisch Onderwijs. 1999;18:66-73

van der Weijden T, van Bokhoven MA, Dinant GJ, van Hasselt CM, Grol RPTM. Understanding laboratory testing in diagnostic uncertainty: a qualitative study in general practice. $\mathrm{Br} \mathrm{J}$ Gen Pract. 2002;52:974-80

van Bokhoven MA, Kok G, van der Weijden T. Designing a quality improvement intervention: a systematic approach. Qual Saf Health Care. 2003:12:215-20

Dinant GJ, Hopstaken R, van Bokhoven M. Implementatie van diagnostisch onderzoek in de dagelijkse praktijk: de paradox tussen evidence en practice. Huisarts Wet. 2004;47:99-102

Houben PHH, van der Weijden $T$, van Bokhoven MA, Droog AE, Winkens $R$, Grol RPTM. Overwegingen van huisartsen bij het interpreteren van uitslagen van laboratoriumonderzoek. Een kwalitatief onderzoek. Huisarts Wet. 2005;48:326-32

van Bokhoven MA, Koch $H$, van der Weijden T, Bindels PJE, Grol RPTM, Dinant GJ. Blood test ordering for unexplained complaints in general practice, the VAMPIRE randomised clinical trial protocol. BMC Family Practice. 2006;7:20

van Bokhoven MA, Pleunis-van Empel MCH, Koch H, Grol RPTM, Dinant GJ, van der Weijden T. Why do patients want to have their blood tested? A qualitative study of patient expectations. BMC Family Practice. 2006;7:75

Koch $H$, van Bokhoven MA, ter Riet G, van der Weijden T, Dinant GJ, Bindels PJE. Demographic characteristics and quality of life of patients with unexplained complaints: a descriptive study in general practice. Qual Life Res. 2007;16:1483-9

Swinkels DW, Jorna ATM, Raymakers RAP, on behalf of the members of the working party. Synopsis of the Dutch multidisciplinary guideline for the diagnosis and treatment of hereditary haemochromatosis. Neth J Med. 2007;65:452-5

van Bokhoven MA, Koch $H$, van der Weijden $T$, Dinant GJ. Special methodological challenges when studying the diagnosis of unexplained complaints in primary care. J Clin Epidemiol. 2008;61:318-22

van Bokhoven MA, Koch H, Dinant GJ, Bindels PJE, Grol RPTM, van der Weijden T. Exploring the black box of change in improving test-ordering routines. Fam Pract. 2008;25:139-45

Koch $H$, van Bokhoven MA, ter Riet G, van Alphen-Jager JM, van der Weijden T, Dinant GJ, Bindels PJE. Ordering blood tests for patients with unexplained fatigue in general practice: what does it yield? Results of the VAMPIRE study (ISRCTN55755886). Br J Gen Pract. Provisionally Accepted 
van Bokhoven MA, Koch $H$, van der Weijden T, Grol RPTM, Kester AD, Rinkens PELM, Bindels PJE, Dinant GJ. The influence of a watchful waiting approach on satisfaction and anxiety among patients presenting with unexplained complaints in family practice. Submitted

van Bokhoven MA, Koch $H$, van der Weijden T, Weekers-Muyres AHM, Bindels PJE, Grol RPTM, Dinant GJ. The effect of watchful waiting instructions on GPs' blood test ordering behaviour for patients with unexplained complaints; a randomised clinical trial (ISRCTN 55755886). Submitted

van Bokhoven MA, Koch H, van der Weijden T, Ament A, Bindels PJE, Grol RPTM, Dinant GJ. The costs of watchful waiting compared to immediate blood test ordering in patients with unexplained complaints in general practice, a randomised clinical trial [ISRCTN55755886]. Submitted

Koch $H$, van Bokhoven MA, ter Riet $G$, Hessels $K M$, van der Weijden T, Dinant GJ, Bindels PJE. What makes general practitioners order blood tests for patients with unexplained complaints? A cross-sectional study. Submitted

Koch $H$, van Bokhoven MA, ter Riet G, van der Weijden T, Dinant GJ, Bindels PJE. The course of newly presented unexplained complaints in general practice patients; a prospective cohort study. Submitted

Stolper $E$, van Bokhoven MA, Houben $P$, van Royen $P$, van de Wiel $M$, van der Weijden $T$, Dinant GJ. The role of gut feelings in general practice. Submitted

Stolper $E$, van Royen $P$, van de Wiel $M$, van Bokhoven MA, Houben $P$, van der Weijden $T$, Dinant GJ. Consensus on gut feelings in general practice. Submitted

\section{Book Contributions}

van Bokhoven MA. Diagnostiek door de huisarts bij zeldzame aandoeningen. In: Drenthen $T$, Hielkema- de Meij JE, Middelveldt I, van Rijn van Alkemade E, Coolen van Brakel RJWM, Dik E, editors. Invitational Conference Informatievoorziening zeldzame aandoeningen via de huisarts. Utrecht: DGV Nederlands instituut voor verantwoord medicijngebruik; 2002

van Bokhoven MA, Koch $H$. Vague Medical Problems In Research: Het verbeteren van aanvraaggedrag bij onbegrepen klachten in de huisartsenpraktijk. In: Harmsen $M$, Wensing $M, G r o l$ RPTM, editors. Implementatie van richtlijnen en innovaties Lessen uit de praktijk. Nijmegen: Centre for Quality of Care Research (WOK); 2002

van Bokhoven MA, Kok $G$, van der Weijden $T$. Designing a quality improvement intervention: a systematic approach. In: Grol RPTM, Baker R, Moss F, editors. Quality improvement research. first ed. London: BMJ Publishing Group; 2004

van Bokhoven MA, Dinant G. De waarde van de Hb-bepaling bij onbegrepen moeheid. In: van den Bosch WJHM, Treffers PE, editors. Anemie. Serie Bijblijven. Houten: Bohn Stafleu Van Loghum; 2005

van Bokhoven MA, Houben $\mathrm{P}$, Chavannes $\mathrm{N}$, Nijholt $\mathrm{A}$. The white man has big eyes but does he see? Students' experiences and background information to prepare yourself for an elective in a developing country. Maastricht: Universiteit Maastricht; 2006

van Bokhoven MA, Koch $H$. Tijd heelt alle wonden? Bloedonderzoek bij onbegrepen klachten. In: Dinant GJ, Spigt MG, Knottnerus JA editors. Praktische epidemiologie. Serie praktische huisartsgeneeskunde, een serie voor opleiding en nascholing. 2008. Maarssen, Elsevier gezondheidszorg

van Bokhoven MA. Moeheid. In: Beenhakker $M$ en Schers $H$, editors. Probleemgeoriënteerd denken in de huisartsgeneeskunde. Utrecht: De Tijdstroom; in press 


\section{Curriculum vitae}

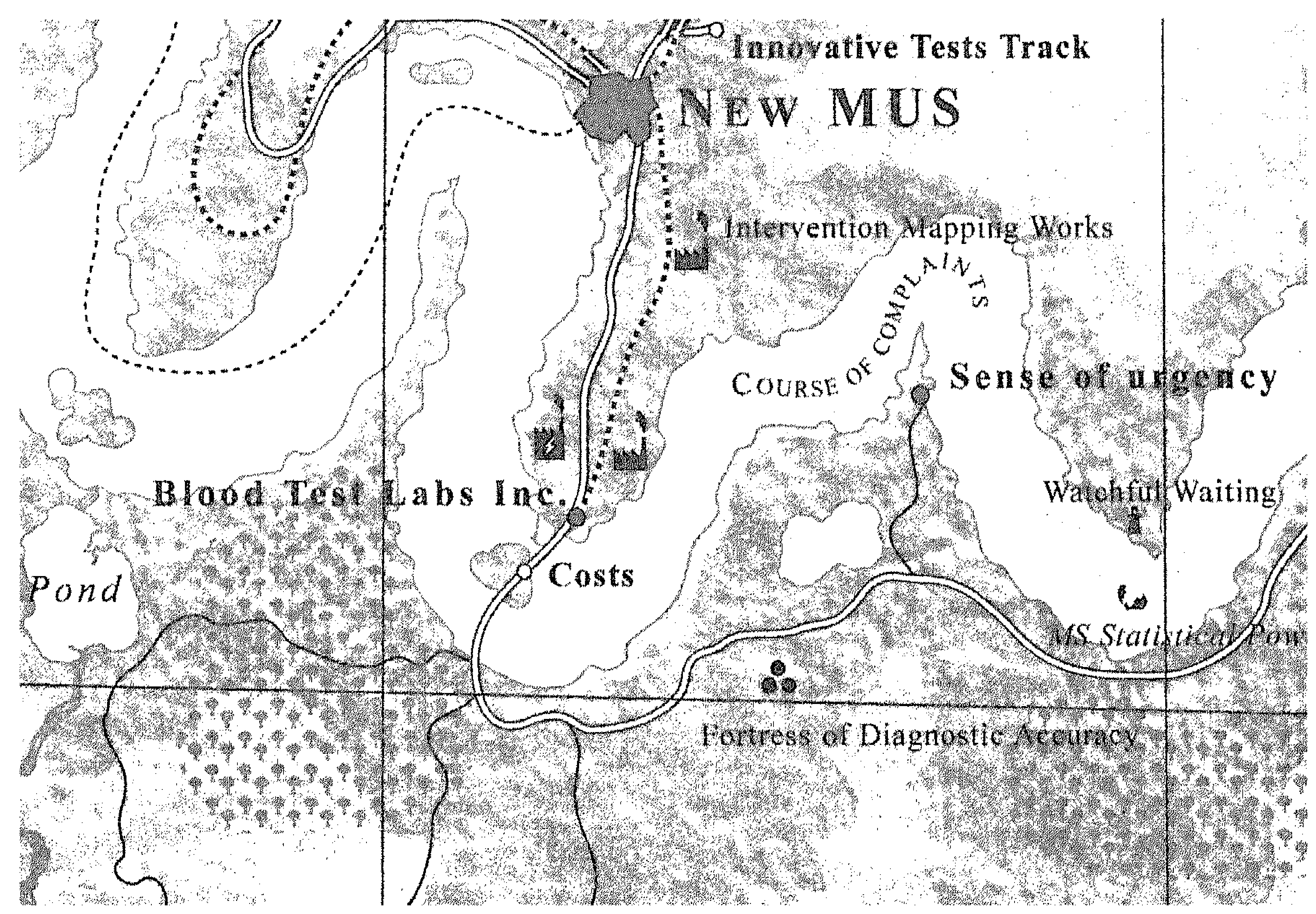




\section{Curriculum vitae}

Loes van Bokhoven was born in Schijndel, The Netherlands, on November 6 , 1972.

From 1985-1991 she attended secondary school at Gymnasium Bernrode in Heeswijk-Dinther. After receiving her gymnasium $\beta$ diploma she started her medical studies at Maastricht University. During her studies she was actively involved in several educational committees at the university and spent an elective in community medicine at the University of the East in Manila, The Philippines. In January 1998 she graduated as a medical doctor (cum laude) and started working as a skills teacher at the Skillslab of Maastricht University. She combined this with a post as a resident in the outpatient department for patients with chronic pain at the Rehabilitation Foundation Limburg in Hoensbroek.

In September 1998 she started part time with the VAMPIRE project that resulted in this thesis at the Department of General Practice, Care and Public Health Research Institute (CAPHRI) of Maastricht University. The VAMPIRE project was carried out in close collaboration with the Department of General Practice from the Academic Medical Center-University of Amsterdam.

From September 1999 until June 2004 she combined research with vocational training in general practice in the practices of Fons van der Poel (Kerkrade) and Tonnie van Kessel and Gijsbert de Koning (academic health care centre 'Withuis', Venlo). Since spring 2006 she has been working as a GP in an academic general practice in Elsloo, together with Henk Jochems, Jos Boesten and Laury de Jonge. She will continue her academic work as a post-doctoral researcher and teacher at the department of General Practice in Maastricht.

Loes is happily married to Martijn Poeze and the proud mother of son Jelle (2003) and daughter Elke (2006). 